NISTIR 7145-REVISED

\title{
Analysis of Ventilation Data from the U.S. Environmental Protection Agency Building Assessment Survey and Evaluation (BASE) Study
}

\author{
Andrew Persily \\ Josh Gorfain
}




\section{Analysis of Ventilation Data from the U.S. Environmental Protection Agency Building Assessment Survey and Evaluation (BASE) Study}

Andrew Persily Building and Fire Research Laboratory

Josh Gorfain Building and Fire Research Laboratory

Prepared for: U.S. Environmental Protection Agency

Washington, DC

November 2008

(replaces version published in December 2004)

U.S. Department of Commerce Carlos M. Gutierrez, Secretary

National Institute of Standards and Technology Patrick Gallagher, Acting Director

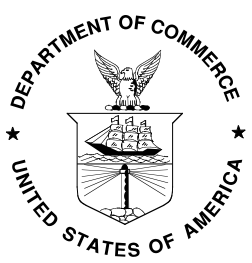




\section{ABSTRACT}

The U.S. Environmental Protection Agency (EPA) Building Assessment Survey and Evaluation (BASE) study included a range of measurements in 100 randomly selected U.S. office buildings for the purpose of characterizing the existing building stock with respect to determinants of indoor air quality and occupant perceptions of indoor environments. One aspect of the evaluation was the characterization of the ventilation systems serving the study spaces and selected measurements of ventilation performance. This report presents an analysis of these data with a focus on supply and outdoor airflows, including comparisons of the measured data with design values and the outdoor air requirements in ASHRAE Standard 62-2001. The results indicate that, as expected based on thermal load considerations, the average value of the design and measured supply airflow are both about $5 \mathrm{~L} / \mathrm{s}^{\bullet} \mathrm{m}^{2}\left(1 \mathrm{cfm} / \mathrm{ft}^{2}\right)$. The measured outdoor air ventilation is higher than might be expected, with a mean value of $49 \mathrm{~L} / \mathrm{s}(105 \mathrm{cfm})$ per person based on volumetric airflow measurements at the air handlers and measured occupant densities. These outdoor air ventilation values are high on average relative to the minimum outdoor air requirements in Standard 62 due to the high outdoor air fractions (relative to minimum) and the actual occupancy being on average $80 \%$ of the design occupancy. Nevertheless, about $17 \%$ of the ventilation measurements are still below the $10 \mathrm{~L} / \mathrm{s}(20 \mathrm{cfm})$ per person requirement in Standard 62. Under conditions of minimum outdoor air intake and accounting for the lower occupancy levels, the mean ventilation rate is roughly $11 \mathrm{~L} / \mathrm{s}(22 \mathrm{cfm})$ per person and about onehalf of the values are below the per person requirement in Standard 62. In addition, this report contains a number of suggested modifications to the protocol used in these assessments for consideration in future studies.

This report is a revision of the original report on these data published in 2004. This revision reflects some additional analyses of the data, which results in some changes to the numerical values reported, but not to the overall conclusions. The additional analyses are discussed in Appendix F of this report, which was published as a NIST Letter Report in October 2008. All values in this revised report that have changed relative to the original report are noted in bold font. Those tables and figures have been updated are also noted in bold font in the lists of tables and figures page vii and viii respectively.

Keywords: carbon dioxide, design, measurement, mechanical ventilation, office buildings, ventilation 


\section{TABLE OF CONTENTS}

Abstract__ iii

List of Tables__ vi

List of Figures___vii

1. INTRODUCTION AND BACKGROUND__ 1

1.1 EPA BASE Study__ _ 1

1.2 Objectives of Ventilation Analysis___ 3

2. METHODOLOGY_ 3

2.1 Buildings, Study Spaces and Air Handling Systems ___ 3

2.2 Measured Data___ 4

2.3 Timing of Building Evaluations___ 6

3. RESULTS _ 8

3.1 Building and Study Space Information___ 8

3.2 Ventilation System Design Parameters___ 9

3.3 Exhaust System Design and Building Airflow Balance___ 16

3.4 Measured Occupant Density___ 17

3.5 Ventilation System Performance Measurements___ 18

3.5.1 Supply Airflow___ 18

3.5.2 Outdoor Air Fraction___ 20

3.5.3 Outdoor Air Ventilation___ 26

3.5.4 Outdoor Airflows from Peak Carbon Dioxide___ 29

3.5.5 Supply Diffuser Airflows___ 33

3.5.6 Exhaust Airflows___ 33

4. DISCUSSION__ 34

4.1 Summary of Conclusions___ 34

4.2 Comparison with European Audit Project____ 35

4.3 Recommendations for Ventilation Assessment Protocols___ 36

5. ACKNOWLEDGEMENTS___ 37

6. REFERENCES___ 38

Appendix A: BASE Variables Used in Analysis___ 40

Appendix B: System Design Information___ 42

Appendix C: Volumetric Airflow Data Issues___ 49

Appendix D: Measured Data for Air Handlers___ 51

Appendix E: Measured Data for Study Spaces___ 72

Appendix F: Reanalysis of BASE Ventilation Data___ 93 


\section{LIST OF TABLES}

1. HVAC performance parameters___ 2

2. Building information 8

3. Study space information _ 9

4. Ventilation system types___ 10

5. Outdoor air intake control____ 10

6. System design values___ 11

7. System design outliers___ 12

8. Outdoor air requirements based on Standard 62 addendum $n \_13$

9. Reported frequencies of selected system maintenance activities___ 14

10. Summary of exhaust system design values___ 16

11. Net design airflow analysis___ 17

12. Summary of measured occupant density___ 17

13. Summary of measured supply airflows___ 19

14. Summary of measured outdoor air fraction __ 21

15. Summary of measured outdoor air ventilation - volumetric __ 27

16. Summary of measured outdoor air ventilation $-\mathrm{CO}_{2}$ ratio__ 28

17. Outdoor air ventilation adjusted for occupancy and outdoor air fraction___ 29

18. Summary of measured outdoor air ventilation - Peak $\mathrm{CO}_{2} \ldots 30$

19. Outdoor air ventilation for naturally ventilated spaces___ 32

20. Summary of measured supply airflows at diffusers___ 33 


\section{LIST OF FIGURES}

1. Frequency distribution of measurement based on month

2. Frequency distribution of measurement based on outdoor temperature __ 7

3. Design supply airflow capacity versus year built___ 14

4. Design minimum outdoor air intake versus year built___ 15

5. Design occupant density versus year built__ 15

6. Ratio of measured to design supply airflow versus outdoor temperature __ 19

7. Measured study space supply airflow versus outdoor temperature ___ 20

8. Volumetric outdoor air fraction versus outdoor temperature _ 22

9. Outdoor air fraction for an idealized economizer cycle___ 22

10. Measured air change rates versus outdoor air temperature (Persily et al. 1992)___ 23

11. Return minus outdoor air $\mathrm{CO}_{2}$ concentration versus time of day _ 24

12. Outdoor air fraction based on $\mathrm{CO}_{2}$ versus volumetric __ 25

13. Ratio of measured to design outdoor airflow versus outdoor temperature___ 26

14. Outdoor air ventilation, $\mathrm{CO}_{2}$ ratio versus volumetric __ 28

15. Outdoor air ventilation, $\mathrm{CO}_{2}$ peak versus volumetric ___ 31 


\section{INTRODUCTION AND BACKGROUND}

Building ventilation is a primary determinant of indoor air quality (IAQ) in buildings as it impacts indoor contaminant concentrations and occupant comfort. However, relatively few measurements of office building ventilation performance have been conducted, and those data that exist generally have not employed consistent measurement methods and have not involved representative collections of buildings. As discussed below, the EPA Building Assessment Survey and Evaluation (BASE) study was conducted to assess IAQ, including ventilation, in a large number of randomly selected office buildings throughout the U.S. using a standardized protocol. Ventilation performance assessment was a key part of the survey, and this report presents an analysis of the ventilation data collected during the study. The building evaluations were conducted by EPA contractors, and the analysis presented in this report is based on the ventilation data collected by the contractors.

\subsection{EPA BASE Study}

The EPA BASE study was originally conceived to address the IAQ data gap in public and commercial office buildings. As described in the protocol for the study (EPA 2003), the primary goal of the study was to define the status of the existing building stock with respect to determinants of IAQ and occupant perceptions. The study was also intended to provide data that would form the basis for future building studies, as well as provide guidance on building design, construction, operation, and maintenance. EPA assembled a steering committee to support the design, planning, and implementation of the effort in the following areas: study design; building and heating, ventilating, and air conditioning (HVAC) characteristics; human response and questionnaires; environmental measurements; diagnostics and mitigation; and program integration. A protocol was then developed that incorporated the three major study areas: comfort and environmental measurements; building and HVAC characterization; and an occupant questionnaire. While certain aspects of the entire building were characterized, one or more representative sampling spaces (referred to in this report as study spaces) in each building were more intensively characterized due to cost and time limitations. Ultimately the data from the study will reside in a publicly accessible database, and it is expected that the data will be used for a number of applications, such as: developing distributions of IAQ, building and HVAC characteristics; developing new hypotheses regarding, for example, the causes of occupant symptoms; establishing standardized protocols for IAQ studies; examining the relationship of symptoms to building characteristics; and, developing guidance on building design, construction, operation, and maintenance.

Buildings included in the sample were not intended to be IAQ complaint buildings, although some complaint buildings may have been included. However, buildings that had been highly publicized by the media for their IAQ problems were excluded. The building sampling strategy randomized the sample to the extent possible, limited by the success in gaining access to buildings. Over the five-year period from 1994 to 1998, 100 buildings were studied as part of the BASE program. Each building was studied for a one-week period, generally in either the summer or winter, during which the various measurements were conducted. On Wednesdays and Thursdays of that week, HVAC system performance measurements were made at the same time that environmental measurements were made in the occupied space. These HVAC performance measurements were generally made at approximately 9:30 a.m. and 2:30 p.m. on each day. The HVAC performance measurements are described briefly in Table 1, which also contains the number of the data form from the BASE protocol. 


\begin{tabular}{|l|l|c|}
\hline \multicolumn{1}{|c|}{ Parameter } & \multicolumn{1}{|c|}{ Monitoring approach } & $\begin{array}{c}\text { Form } \\
\text { Number* }\end{array}$ \\
\hline $\begin{array}{l}\text { Supply and recirculation } \\
\text { airflow }\end{array}$ & $\begin{array}{l}\text { Duct traverse for each air handling unit (AHU) serving } \\
\text { study space using pitot tube or hot-wire anemometer. }\end{array}$ & E-1 \\
\hline Percent outdoor air intake & $\begin{array}{l}\text { Calculation from carbon dioxide }\left(\mathrm{CO}_{2}\right) \text { concentration } \\
\text { measured in outdoor air and the supply and return air of } \\
\text { each AHU serving the study space. }\end{array}$ & E-1 \\
\hline Outdoor air intake & $\begin{array}{l}\text { For each AHU serving the study space, duct traverse in } \\
\text { the outdoor air intake duct. If not possible, estimate from } \\
\text { difference between supply and recirculation airflow. }\end{array}$ & E-1 \\
\hline $\begin{array}{l}\text { Supply air temperature and } \\
\text { relative humidity }\end{array}$ & $\begin{array}{l}\text { Measurement in supply air duct for each AHU serving } \\
\text { study space. }\end{array}$ & E-1 \\
\hline Exhaust fan operation & $\begin{array}{l}\text { Observation by technician mornings and afternoons of } \\
\text { monitoring days }\end{array}$ & E-3 \\
\hline Exhaust fan airflow & $\begin{array}{l}\text { Measurement of airflow rates of all exhaust fans serving } \\
\text { the study space using flow capture hood or duct traverse; } \\
\text { measurement of individual exhaust grilles within the } \\
\text { study area; one time measurement. }\end{array}$ & E-4 \\
\hline $\begin{array}{l}\text { Local ventilation } \\
\text { performance }- \text { supply } \\
\text { airflow }\end{array}$ & $\begin{array}{l}\text { Measurement of airflow from all supply diffusers serving } \\
\text { the study space (preferred) using flow capture hood; } \\
\text { measure a minimum of 50\% of the supply diffusers } \\
\text { serving the study space. }\end{array}$ & E-2 \\
\hline $\begin{array}{l}\text { Outdoor air ventilation rate } \\
- \text { continuous } \mathrm{CO}_{2}\end{array}$ & $\begin{array}{l}\text { Estimation of ventilation from continuous CO } 2 \\
\text { concentration at three locations in study space; only } \\
\text { method used in naturally ventilated buildings }\end{array}$ & E-5 \\
\hline
\end{tabular}

* Form number for data collection in BASE protocol.

\section{Table 1 HVAC performance parameters}

The study areas in each building were selected based on the following criteria (EPA 2003):

- Number of occupants: 25 occupants who work for 20 or more hours per week and are available to complete the questionnaire, but preferably 50 to 60 such occupants.

- Served by no more than two air-handling units, but preferably just one.

- A maximum of three floors, but preferably just one.

- Preferably floor area not to exceed $1900 \mathrm{~m}^{2}\left(20000 \mathrm{ft}^{2}\right)$

There have been previous analyses of the building and HVAC data, as well as some papers describing the BASE study in more general terms (Brightman et al. 1996, Womble et al. 1995 and 1996). Ludwig et al. (2002) present an analysis of the ventilation data, including a comparison with the outdoor air requirements in ASHRAE Standard 62-1999 (ASHRAE 1999). They conclude that ventilation rates based on indoor $\mathrm{CO}_{2}$ levels have lower uncertainties than the rates based on the other methods considered and that most of the measured values are higher than the requirements in Standard 62. However, the uncertainties considered are based only on instrumentation specifications and do not consider other sources of error. In particular, the uncertainties of the ventilation estimates using indoor $\mathrm{CO}_{2}$ are based on only the concentration measurements and not on validity of the assumptions inherent in the mass balance methodology used to make these estimates. Also, their analysis did not investigate ventilation system design values and did not address other ventilation performance parameters of interest, such as supply airflows. Apte et al. (2000) and Erdman et al. (2002) examine associations between sick building syndrome symptoms and indoor-outdoor $\mathrm{CO}_{2}$ concentration differences as surrogates for per person ventilation rates. 


\subsection{Objectives of Ventilation Analysis}

The purpose of the analysis presented in this report is to produce information on ventilation system design and performance for the 100 BASE office buildings. While there have been some studies of ventilation in office buildings (Persily 1989, Persily and Dols 1991, Persily at al. 1992), none have been associated with such thorough characterizations of indoor environmental conditions and occupant symptoms nor have they been applied to a representative set of buildings. Therefore, the BASE data provide a unique opportunity to obtain important information about U.S. office buildings including ventilation system design values, measured ventilation performance, and the relationship of these measurement results to design values and to requirements in standards. While the following sections describe the specific parameters that are considered, the focus of this analysis is primarily on supply airflows and outdoor air ventilation. It is envisioned that the results of this analysis will be used to investigate relationships of ventilation to IAQ performance parameters and to occupant symptoms. In addition to providing design and measured ventilation data, this study was performed to evaluate the BASE protocol with respect to its ability to obtain reliable ventilation performance data and to recommend modifications to the protocol for use in future studies.

\section{METHODOLOGY}

The data analysis involved calculations of various parameters using the data obtained by the EPA contractor, most of which is described in the results section. The overall analysis approach is summarized in this section, along with a more detailed discussion of some specific parameters such as the outdoor air fraction of an air handler.

The analysis focused primarily on the study spaces and the ventilation systems serving these spaces in terms of both design and measured performance. As noted earlier, the study spaces were portions of buildings, or in some cases whole buildings, that were the subject of the BASE study test protocol. In this study, ventilation design and performance is assessed primarily in terms of supply airflow and outdoor air intake, along with exhaust airflows to a lesser degree. In addition, occupancy levels are examined. All of the analysis performed by NIST employs data that were provided by EPA, much of which had already been processed by their contractors. For example, the data from duct traverses had already been converted into volumetric airflows. NIST did not use the raw data from the field to verify the processing done by the contractor, as the protocol and data processing already had significant quality control checks. The BASE variables used in the NIST analysis, as well as those obtained from the contractor's analysis, are identified in Appendix A.

The analysis results are presented in the form of the following summary statistics for the variables of interest: mean, standard deviation, median, the $10^{\text {th }}, 25^{\text {th }}, 75^{\text {th }}$ and $90^{\text {th }}$ percentile values, and the minimum and maximum values.

\subsection{Buildings, Study Spaces and Air Handling Systems}

The data analysis focused first on the buildings involved in the BASE study and the study spaces in the buildings. Basic information was analyzed to characterize the age and size of the buildings as well as the size and occupancy of the study spaces. The air handling systems serving the study spaces were examined in terms of the types of system, means of outdoor air intake control, and system design specifications. The latter includes supply, return and minimum outdoor airflow capacity and design occupant density. The system design airflows were obtained as part of the BASE protocol, when available, from system specifications and other design documentation. The primary outcomes of these analyses are the supply airflow capacity per unit floor area, expressed 
as $\mathrm{L} / \mathrm{s} \bullet \mathrm{m}^{2}\left(\mathrm{cfm} / \mathrm{ft}^{2}\right)$, and the minimum outdoor air intake in $\mathrm{L} / \mathrm{s} \bullet$ person (cfm/person). These design parameters are then examined as a function of building age to determine if any trends over time are evident. In addition, the design capacities of the exhaust ventilation systems are examined, including their contribution to the net airflow balance of the building.

\subsection{Measured Data}

The analysis of the measured data focused on the following ventilation performance parameters: supply airflow, outdoor air fraction, outdoor air ventilation, and exhaust airflow. An uncertainty analysis is performed for all the calculated parameters based on propagation of the uncertainty estimates for each of the measured quantities, i.e., $30 \%$ for the measured outdoor air intake and recirculation airflow, $10 \%$ for the supply airflows, and $90 \mathrm{mg} / \mathrm{m}^{3}(50 \mathrm{ppm}(\mathrm{v}))$ for the $\mathrm{CO}_{2}$ concentrations. The uncertainties of the airflows are estimates from an analysis by the EPA contractor who performed the tests (EHE 2001a). The actual uncertainties may very well be larger, or perhaps smaller, than these estimates; however, there is insufficient information available to develop better estimates of the measurement uncertainties. The value for the $\mathrm{CO}_{2}$ monitors is based on the instrumentation specifications in the study protocol.

\section{Occupant Density}

As part of the BASE protocol, the number of occupants in each study space was counted twice a day for at least two days during the test week. These data are analyzed to determine the occupant density of each space in units of number per $100 \mathrm{~m}^{2}\left(1000 \mathrm{ft}^{2}\right)$. These values are compared with the design occupancy based on the number of workstations in each study space and with the occupant density values in ASHRAE Standard 62-2001 (ASHRAE 2001a) and in addendum $n$ to that standard (ASHRAE 2003).

\section{Supply Airflow}

The measured supply airflows for the individual air handlers are first compared with the design values. The ratios of measured to design are then evaluated as a function of system type and outdoor air temperature. The supply airflows for the air handlers were combined to determine the total supply airflow to each study space. The supply airflow to each study space was based on the percentage of the air handler airflow serving the study space, which is a variable determined in the ventilation system evaluation. The survey protocol did not provide an uncertainty estimate for these percentages. For the purposes of this analysis, the uncertainty is assumed to equal $10 \%$ of the value except in cases where $100 \%$ of the air is delivered to the study space. In those cases the uncertainty is assumed to be zero. The study space supply airflows are normalized by floor area served and examined as a function of outdoor air temperature.

\section{Outdoor Air Fraction}

A key ventilation performance parameter assessed in the study is the outdoor air fraction $\mathrm{F}_{\mathrm{o}}$, i.e., the ratio of the outdoor air intake to the supply airflow. It is of interest as a performance parameter itself and as a means of determining the outdoor air intake through multiplication by the supply airflow. The outdoor air fraction was determined in two ways, dividing the measured outdoor airflow by the measured supply airflow and through the measurement of $\mathrm{CO}_{2}$ concentrations in the outdoor, supply and recirculation airstreams. The former determination is referred to as a volumetric value, while the latter is referred to as the $\mathrm{CO}_{2}$ ratio value.

The volumetric outdoor air fraction was determined for each air handler measurement based on whichever of the expressions in Equations (1a), (1b) and (1c) apply. In Equation (1a), $\mathrm{F}_{\mathrm{o}^{-}}$ volumetric is determined by the measured outdoor air intake divided by the supply airflow. In 
cases where the outdoor air intake was not measured directly but the supply and recirculation flows were measured, $\mathrm{F}_{\mathrm{o}}$-volumetric was determined using Equation (1b). Finally, in cases where the supply airflow was not measured, $\mathrm{F}_{\mathrm{o}}$-volumetric was determined using Equation (1c) based on the sum of the outdoor and recirculation airflows. Mathematically, these three means of determining the volumetric intake fraction are expressed as follows:

$$
\begin{aligned}
& \mathrm{F}_{\mathrm{o}}=\mathrm{Q}_{\mathrm{O}} / \mathrm{Q}_{\mathrm{S}} \\
& \mathrm{F}_{\mathrm{o}}=\left(\mathrm{Q}_{\mathrm{S}}-\mathrm{Q}_{\mathrm{R}}\right) / \mathrm{Q}_{\mathrm{S}} \\
& \mathrm{F}_{\mathrm{o}}=\mathrm{Q}_{\mathrm{O}} /\left(\mathrm{Q}_{\mathrm{O}}+\mathrm{Q}_{\mathrm{R}}\right)
\end{aligned}
$$

where $\mathrm{F}_{\mathrm{o}}$ is the outdoor air fraction and $\mathrm{Q}_{\mathrm{O}}, \mathrm{Q}_{\mathrm{S}}$ and $\mathrm{Q}_{\mathrm{R}}$ are the outdoor, supply and recirculation airflows respectively. The value of $\mathrm{F}_{\mathrm{o}}$ with the minimum uncertainty was identified and is referred to as the best volumetric value of $F_{0}$. For some air handlers, the value of $F_{o}$ could be determined using more than one of these expressions. For a small number of cases in which only Equation (1b) could be used, the value of $\mathrm{Q}_{\mathrm{S}}$ was less than $\mathrm{Q}_{\mathrm{R}}$, resulting in a negative value. In those cases, the outdoor air fraction and $Q_{0}$ were both set to zero, but the large uncertainty values were carried through the analysis.

Values of $\mathrm{F}_{\mathrm{o}}$ were also determined based on measured $\mathrm{CO}_{2}$ concentrations in the outdoor, supply and recirculation airstreams using Equation (2),

$$
\mathrm{F}_{\mathrm{o}}=\left(\mathrm{C}_{\mathrm{R}}-\mathrm{C}_{\mathrm{S}}\right) /\left(\mathrm{C}_{\mathrm{R}}-\mathrm{C}_{\mathrm{O}}\right)
$$

where $\mathrm{C}_{\mathrm{R}}, \mathrm{C}_{\mathrm{S}}$ and $\mathrm{C}_{\mathrm{O}}$ are the $\mathrm{CO}_{2}$ concentrations in the supply, recirculation and outdoor airstreams respectively.

\section{Outdoor Air Ventilation}

Outdoor air intake is determined for individual air handlers using whichever of the following approaches was possible:

- Direct measurements of the volumetric airflow in the outdoor air intake duct using standard air speed traverse approaches.

- The difference between direct measurements of the supply and recirculation volumetric airflows.

- The outdoor air fraction based on $\mathrm{CO}_{2}$ (see Equation (2)) multiplied by the supply airflow.

The measured outdoor airflows for the individual air handlers are compared with the design values for minimum outdoor air for the systems where such a design value exists. The ratios of the measured to design values are evaluated as a function of system type and outdoor air temperature. Based on the measurements at the individual air handlers, the outdoor air ventilation in each study space is calculated. These calculations employ the value of the percentage of the air from each handler that is provided to the study space. As noted above, the protocol does not provide an uncertainty estimate for these values, and the uncertainty is assumed to equal $10 \%$ except when the value is $100 \%$.

The outdoor air ventilation in the study space is also estimated based on the $\mathrm{CO}_{2}$ concentrations measured with the fixed monitors used in the study. A number of such monitors were deployed in each study space, which recorded the $\mathrm{CO}_{2}$ concentration (and other variables) every 5 min over several days. The $\mathrm{CO}_{2}$ concentrations were averaged across the study space and the peak value identified. In some cases both a morning and an afternoon peak were identified, if the concentration pattern indicated two distinct peaks. In other cases, only a single peak was determined for the day. The peak concentration minus the corresponding outdoor concentration 
is then used to estimate the outdoor airflow per person assuming that the $\mathrm{CO}_{2}$ concentration is at equilibrium and assuming a $\mathrm{CO}_{2}$ generation rate per person of $0.0052 \mathrm{~L} / \mathrm{s}(0.011 \mathrm{cfm})$. This method is based on a single-zone mass balance of $\mathrm{CO}_{2}$ in the study space and therefore is valid only when the concentration is indeed at steady-state, the concentration is uniform throughout the space, airflows from adjoining spaces can be ignored, and the outdoor concentration, ventilation rate and generation rate are all constant (Persily 1997). Since the validity of these assumptions was not investigated as part of this study (except that the outdoor concentration was monitored), the validity of the results obtained with this method are subject to question.

\section{Supply Diffuser and Exhaust Airflows}

The BASE protocol included one measurement of the supply airflow at the accessible supply air diffusers and the exhaust airflow at exhaust grilles located in the study space. In the case of the supply diffusers, the total supply airflow to the study space is compared with the value based on the measurements at the air handler(s). The measured exhaust airflows are compared with the corresponding design values.

\subsection{Timing of Building Evaluations}

As noted earlier, the goal in the BASE study was to conduct the measurements during the winter and summer when the systems were more likely to be operating at minimum outdoor air conditions and to increase the likelihood that the system operation would not vary over the test week. Figure 1 is a plot of the measurement dates by month of the year. Note the large number of measurements made during the month of March. However, the month does not necessarily indicate the percentage of outdoor air intake; the outdoor air temperature is a better predictor. Figure 2 shows the distribution of the measurements based on the outdoor air temperature at which the ventilation measurements were made. If one assumes that minimum outdoor air intake occurs for air temperatures below $5{ }^{\circ} \mathrm{C}\left(41^{\circ} \mathrm{F}\right)$ and above $20^{\circ} \mathrm{C}\left(68^{\circ} \mathrm{F}\right)$, then 339 of the 548 measurement events (or $62 \%$ ), with the outdoor temperature recorded, would correspond to minimum outdoor air intake. Of course, the percent of outdoor air intake as a function of outdoor temperature depends on the individual system, and some systems were $100 \%$ outdoor air systems. But based on temperature alone, about one-third of the tests might be expected to be at other than minimum outdoor air intake. The issue of percent outdoor air intake, including the temperature dependence, is discussed again when the outdoor air fraction and outdoor air ventilation measurements are presented. 


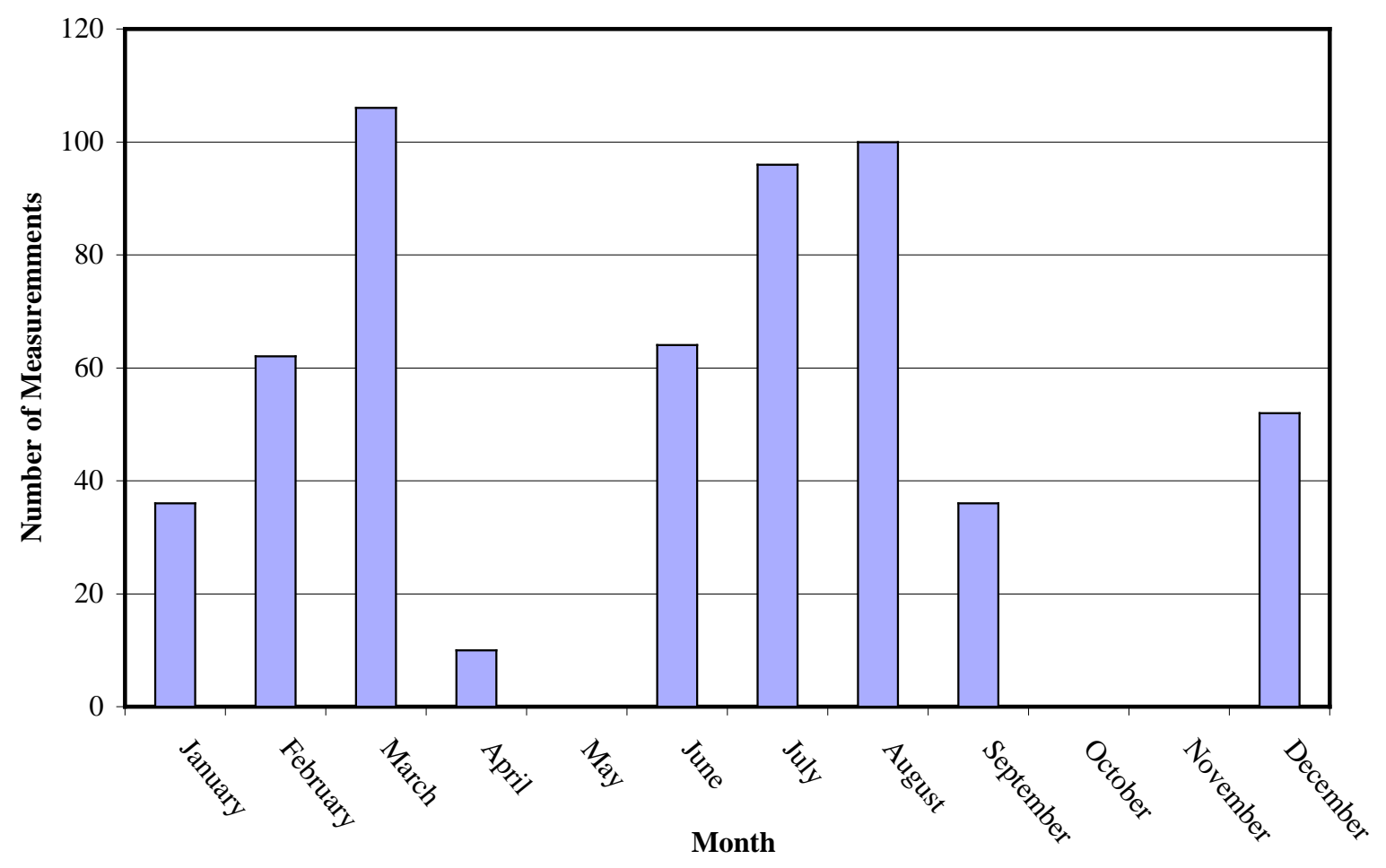

Figure 1 Frequency distribution of measurements based on month

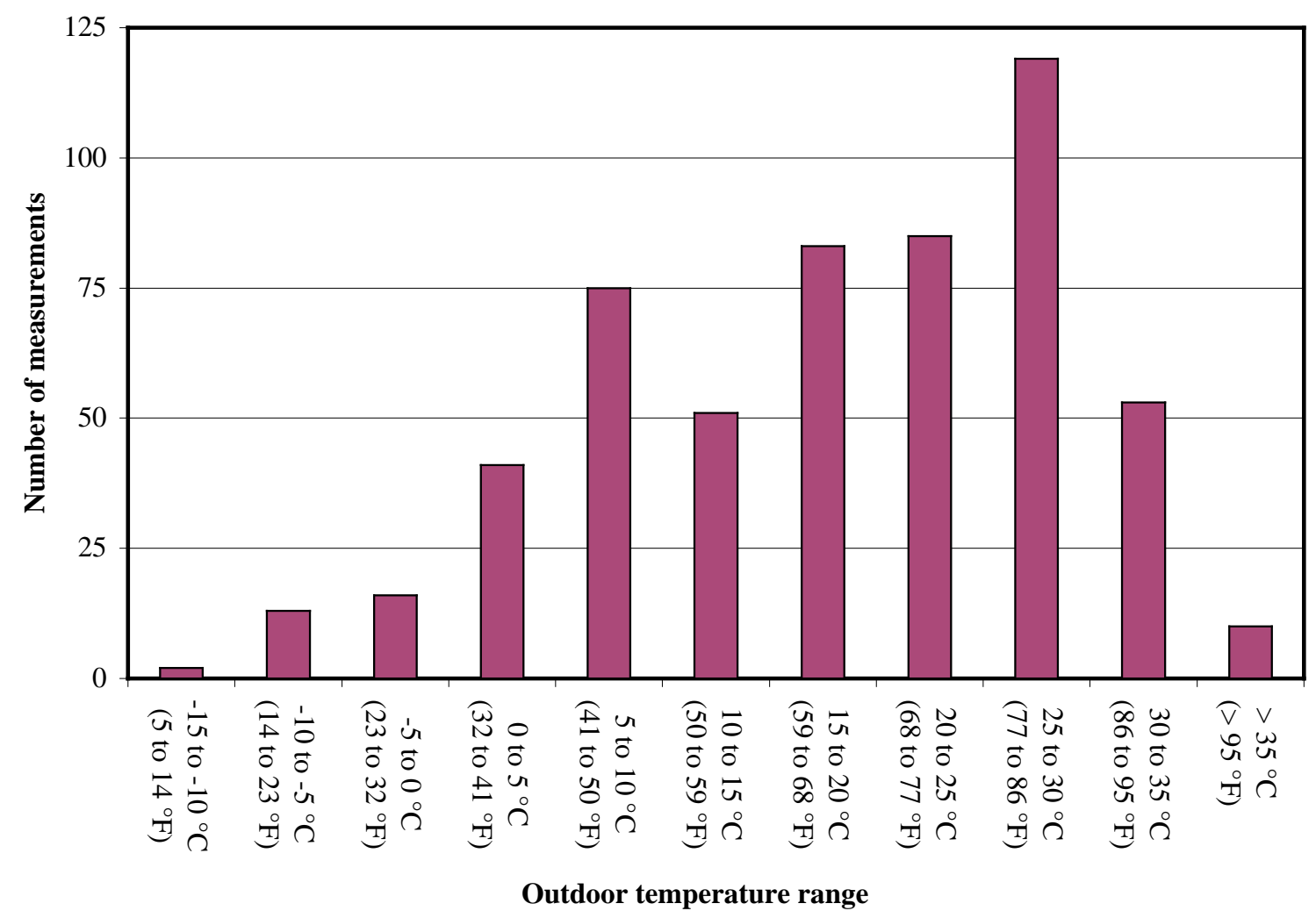

Figure 2 Frequency distribution of measurements based on outdoor temperature 


\section{RESULTS}

This section presents the results of the ventilation analysis performed on the BASE building data. These results include information on the buildings and study spaces, system design parameters, and measured values of occupant density, supply airflow, outdoor air fraction, outdoor air ventilation and exhaust airflow.

\subsection{Building and Study Space Information}

As noted earlier, 100 buildings were involved in the BASE study. These buildings were randomly selected as described in Womble et al. (1995), and were located throughout the United States. Table 1 presents a summary of the characteristics of the buildings. The years of construction range from 1850 to 1996, with a mean of 1961, though most of them have been renovated at some point. The total number of stories, below and above grade, range from 1 to 61 , with a mean of 10 stories. The gross floor area of the buildings range from about $1700 \mathrm{~m}^{2}$ $\left(18000 \mathrm{ft}^{2}\right)$ to $134200 \mathrm{~m}^{2}\left(1445000 \mathrm{ft}^{2}\right)$, with a mean of $24800 \mathrm{~m}^{2}\left(266000 \mathrm{ft}^{2}\right)$. The occupied floor areas, which exclude atria, vacant office space, hallways, stair and elevator shafts, mechanical rooms and core areas, range from $600 \mathrm{~m}^{2}\left(6000 \mathrm{ft}^{2}\right)$ to $98500 \mathrm{~m}^{2}\left(1060000 \mathrm{ft}^{2}\right)$, with a mean of $16400 \mathrm{~m}^{2}\left(177000 \mathrm{ft}^{2}\right)$. Of the 100 buildings, 97 have mechanical ventilation systems while three employ predominantly natural ventilation, i.e., buildings NYBS06, ORIS02 and WAIA01. (These building codes are used in the BASE study to identify each building, with the first two letters indicating the state in which they are located.) Ninety-nine of the buildings are air-conditioned (building WAIA01 being the exception), and all are heated.

\begin{tabular}{|l|c|c|c|c|}
\hline & $\begin{array}{c}\text { Year of } \\
\text { construction }\end{array}$ & $\begin{array}{c}\text { Number of } \\
\text { stories }\end{array}$ & $\begin{array}{c}\text { Gross floor area } \\
\mathrm{m}^{2}\left(\mathrm{ft}^{2}\right)\end{array}$ & $\begin{array}{c}\text { Occupied floor area } \\
\mathrm{m}^{2}\left(\mathrm{ft}^{2}\right)\end{array}$ \\
\hline Mean & 1961 & 10 & $24800(266000)$ & $16400(177000)$ \\
\hline Std. Dev. & 31 & 11 & $27900(300000)$ & $18500(199000)$ \\
\hline Minimum & 1850 & 1 & $1700(18000)$ & $600(6000)$ \\
\hline $10^{\text {th }}$ percentile & 1906 & 3 & $3700(40000)$ & $2300(25000)$ \\
\hline $25^{\text {th }}$ percentile & 1953 & 4 & $7400(80000)$ & $5100(55000)$ \\
\hline Median & 1972 & 6 & $14000(151000)$ & $8500(91000)$ \\
\hline $75^{\text {th }}$ percentile & 1983 & 12 & $27900(300000)$ & $21300(229000)$ \\
\hline $90^{\text {th }}$ percentile & 1988 & 22 & $65100(701000)$ & $35900(386000)$ \\
\hline Maximum & 1996 & 61 & $134200(1445000)$ & $98500(1060000)$ \\
\hline
\end{tabular}

Table 2 Building information

It is interesting to compare the BASE buildings to those included in the 1995 U.S. Department of Energy Commercial Building Energy Consumption Survey or CBECS (DOE 1998). CBECS is a national survey of commercial buildings that is conducted quadrennially with a target population of all commercial buildings in the United States with more than $100 \mathrm{~m}^{2}\left(1000 \mathrm{ft}^{2}\right)$ of floor area. The median age of the CBECS buildings corresponds to a year of construction of 1972, which is identical to the BASE value. The mean floor area of the 1995 CBECS office buildings is $1400 \mathrm{~m}^{2}$ (14900 $\mathrm{ft}^{2}$ ), which is much less than the BASE buildings. However, as noted earlier, the BASE buildings were selected such that the study space had at least 25 occupants and preferably 50 or 60 occupants. The mean number of workers in the CBECS office buildings is 38.4 and $74 \%$ of the office buildings have less than 20 occupants. Therefore the difference in the floor areas between CBECS and BASE is not surprising. Of the 705000 CBECS office buildings, all but 1000 are heated and $98 \%$ are cooled, consistent with the BASE buildings. A 
previous analysis of the BASE buildings relative to the CBECS data notes that the BASE buildings are most representative of office buildings with more than 50 occupants, which constitute roughly $11 \%$ of the office building stock but about $73 \%$ of the U.S. office building occupants (EHE 2001b).

The 100 study spaces within the buildings were selected based on the criteria described above, and some of their characteristics are summarized in Table 3. The occupied floor areas range from $430 \mathrm{~m}^{2}\left(4600 \mathrm{ft}^{2}\right)$ to $6440 \mathrm{~m}^{2}\left(69300 \mathrm{ft}^{2}\right)$, with a mean of $1540 \mathrm{~m}^{2}\left(16600 \mathrm{ft}^{2}\right)$. The mean number of workstations is 72 , which corresponds to 5.3 workstations per $100 \mathrm{~m}^{2}$ of floor area (4.9 per $1000 \mathrm{ft}^{2}$ ). The number of workstations in this table is the sum of the number of private, partitioned and open-space workstations that were counted as part of the study space characterization. The study space characterization also yielded a value for the design floor area per workstation (variable name B1DESWS). Computing the number of workstations per floor area based on B1DESWS yields similar values to those obtained based on the number of workstations as presented in the table, but not identical. The number of workstation density in the table is below the default value of 7 per $100 \mathrm{~m}^{2}\left(1000 \mathrm{ft}^{2}\right)$ in ASHRAE Standard 62-2001, but close to the default value of 5 per $100 \mathrm{~m}^{2}\left(1000 \mathrm{ft}^{2}\right)$ for office space in addendum $\mathrm{n}$ to the standard (ASHRAE 2003). For the 97 study spaces with mechanical ventilation, the mean number of supply air diffusers is 106 and the mean floor area per diffuser of $18.4 \mathrm{~m}^{2}\left(198 \mathrm{ft}^{2}\right)$.

\begin{tabular}{|c|c|c|c|c|c|}
\hline & $\begin{array}{l}\text { Occupied floor } \\
\text { area, } \mathbf{m}^{2}\left(\mathbf{f t}^{2}\right)\end{array}$ & $\begin{array}{c}\text { Number of } \\
\text { workstations }\end{array}$ & $\begin{array}{c}\text { Workstations } \\
\text { per } 100 \mathbf{~ m}^{2} \\
\left(1000 \mathbf{f t}^{2}\right) \\
\end{array}$ & $\begin{array}{l}\text { Number of } \\
\text { supply air } \\
\text { diffusers }\end{array}$ & $\begin{array}{l}\text { Floor area per } \\
\text { diffuser } \mathbf{m}^{2}\left(\mathbf{f t}^{2}\right)\end{array}$ \\
\hline \# of values & 100 & 100 & 100 & 97 & 97 \\
\hline Mean & $1540(16600)$ & 72 & $5.3(4.9)$ & 106 & $18.4(198)$ \\
\hline Std. Dev. & $740(8000)$ & 19 & $2.0(1.9)$ & 53 & $16.1(174)$ \\
\hline Minimum & $430(4600)$ & 39 & $1.0(0.9)$ & 6 & $5.3(57)$ \\
\hline $10^{\text {th }}$ percentile & $880(9500)$ & 50 & $3.0(2.8)$ & 47 & $8.4(91)$ \\
\hline $25^{\text {th }}$ percentile & $1130(12100)$ & 58 & $4.0(3.7)$ & 73 & $10.9(118)$ \\
\hline Median & $1430(15400)$ & 68 & $4.8(4.5)$ & 98 & $15.1(163)$ \\
\hline $75^{\text {th }}$ percentile & $1780(19200)$ & 88 & $6.3(5.8)$ & 132 & $19.8(213)$ \\
\hline $90^{\text {th }}$ percentile & $2250(24200)$ & 100 & $7.6(7.1)$ & 168 & $26.9(290)$ \\
\hline Maximum & 6440 (69 300) & 118 & $12.5(11.6)$ & 281 & $140.0(1507)$ \\
\hline
\end{tabular}

Table 3 Study space information

\subsection{Ventilation System Design Parameters}

The study spaces in the 97 mechanically ventilated buildings are served by a total of 141 mechanical ventilation systems. Of these systems, 50 are constant air volume (CV) and 91 are variable air volume (VAV). CV systems provide a constant amount of supply air, while varying the supply air temperature to meet the heating and cooling loads of the space. VAV systems maintain a constant supply air temperature and vary the supply airflow to meet the loads. The system types are summarized in Table 4 based on the system classification and letter codes in the BASE protocol.

In addition to the system types in Table 4, other design features related to outdoor air intake control were collected for the ventilation systems. Table 5 presents this information for the mechanically ventilated buildings, including the number with systems that employ temperature (dry-bulb) or enthalpy economizer cycles. Twenty-one buildings have dedicated outdoor air fans, 
with 11 of those also conditioning the air. Five buildings have $100 \%$ outdoor air systems, and 88 have fixed minimum outdoor air intake dampers. A small number have the outdoor air intake controlled using airflow monitoring, supply/return fan tracking or building pressure.

\begin{tabular}{|l|c|l|c|}
\hline \multicolumn{1}{|c|}{ Constant volume (CV) } & $\begin{array}{c}\text { Number } \\
\text { of systems }\end{array}$ & \multicolumn{1}{|c|}{ Variable air volume (VAV) } & $\begin{array}{c}\text { Number } \\
\text { of systems }\end{array}$ \\
\hline A Single duct, single zone & 13 & D Single duct & 37 \\
\hline B Single duct, multiple zone reheat & 8 & E Single duct, reheat & 17 \\
\hline J Dual duct & 2 & F Single duct, induction & 7 \\
\hline K Dual duct, reheat & 7 & $\begin{array}{l}\text { G Single duct, fan powered, } \\
\text { constant fan }\end{array}$ & 8 \\
\hline N Multizone & 17 & $\begin{array}{l}\text { H Single duct, fan powered, } \\
\text { intermittent fan }\end{array}$ & 18 \\
\hline O Blow-through bypass & 3 & L Dual duct, single fan & 3 \\
\hline & & M Dual duct, dual fan & 1 \\
\hline TOTAL CV & 50 & TOTAL VAV & 91 \\
\hline
\end{tabular}

Table 4 Ventilation System Types

\begin{tabular}{|l|c|}
\hline \multicolumn{1}{|c|}{ Outdoor air intake control } & $\begin{array}{c}\text { Number of } \\
\text { buildings }\end{array}$ \\
\hline Economizer cycle (temperature control) & 50 \\
\hline Economizer cycle (enthalpy control) & 21 \\
\hline Dedicated outdoor air fan, conditioned & 11 \\
\hline Dedicated outdoor air fan, unconditioned & 10 \\
\hline 100\% outdoor air & 5 \\
\hline Fixed minimum outdoor air damper & 88 \\
\hline Outdoor air intake controlled via monitoring & 2 \\
\hline Outdoor air intake controlled via supply/return fan tracking & 5 \\
\hline Outdoor air intake controlled by building pressure & 4 \\
\hline
\end{tabular}

Table 5 Outdoor air intake control

The availability of design information varies among the systems, however the information that does exist was analyzed and the results are summarized in Table 6. (Detailed design information for all the systems is provided in Appendix B.) Table 6 presents the floor area served by the systems, the design supply airflow capacity normalized by floor area served (for all systems as well as for CV and VAV systems separately), the ratio of design supply to return airflows, the design minimum outdoor air intake per person and per unit floor area, the ratio of the design minimum outdoor air intake to the design supply air capacity, and the occupant density. The occupant density is based on the number of occupants served by the air handler, which was obtained during the surveys from a building walkthrough or from the building management. (During the study space surveys, the actual number of occupants was counted and those results are presented later in this report.) When calculating the supply airflow capacities, the minimum outdoor air intake, and the occupant densities, some values were not in the expected range. These values include supply airflows greater than $15 \mathrm{~L} / \mathrm{s}^{\bullet} \mathrm{m}^{2}\left(3 \mathrm{cfm} / \mathrm{ft}^{2}\right)$, minimum outdoor air intake greater than $33 \mathrm{~L} / \mathrm{s}(70 \mathrm{cfm})$ per person or $5 \mathrm{~L} / \mathrm{s}^{\bullet} \mathrm{m}^{2}\left(1 \mathrm{cfm} / \mathrm{ft}^{2}\right)$, and occupant densities greater than 12 per $100 \mathrm{~m}^{2}\left(1000 \mathrm{ft}^{2}\right)$. Values outside these ranges are included in the statistics in Table 6 , and the outliers themselves are identified in Table 7.

As seen in Table 6, for the 134 air handling systems with design data, the mean value of the design supply airflow normalized by floor area served is $5.86 \mathbf{L} / \mathbf{s}^{\bullet} \mathbf{m}^{2}\left(\mathbf{1 . 1 5} \mathbf{~ c f m} / \mathbf{f t}^{2}\right)$, which is 
close to the expected value of $5 \mathrm{~L} / \mathrm{s} \bullet \mathrm{m}^{2}\left(1 \mathrm{cfm} / \mathrm{ft}^{2}\right)$ based on typical cooling loads and supply air temperatures in office buildings. The median value is even closer to the expected supply airflow rate, and the mean is slightly higher for CV systems and lower for VAV systems. The ratio of the design supply airflow to the design return airflow could be determined for 41 of the systems, and the mean value is 1.14 . This value is consistent with the common design intent to provide more supply than return air to a space to achieve positive pressurization and to ensure that toilet and other exhaust systems are able to function properly.

\begin{tabular}{|l|c|c|c|c|c|}
\hline & \multirow{2}{*}{$\begin{array}{c}\text { Floor area served } \\
\mathrm{m}^{2}\left(\mathrm{ft}^{2}\right)\end{array}$} & \multicolumn{2}{|c|}{ Design supply airflow capacity } & \multirow{2}{*}{$\begin{array}{c}\text { Supply/ } \\
\text { Return }\end{array}$} \\
\cline { 3 - 5 } & 141 & All systems & CV & VAV & 41 \\
\hline \# of values & $\mathbf{3 1 0 0}(\mathbf{3 3 ~ 3 0 0})$ & $\mathbf{5 . 8 6}(\mathbf{1 . 1 5})$ & $7.01(1.38)$ & $\mathbf{5 . 2 5}(\mathbf{1 . 0 3})$ & 1.14 \\
\hline Mean & $\mathbf{4 2 3 0}(\mathbf{4 5} \mathbf{6 0 0})$ & $\mathbf{3 . 5 7}(\mathbf{0 . 7 0})$ & $5.33(1.05)$ & $\mathbf{1 . 8 5}(\mathbf{0 . 3 6})$ & 0.22 \\
\hline Std. Dev. & $\mathbf{1 1 0}(\mathbf{1 2 0 0})$ & $1.13(0.22)$ & $1.13(0.22)$ & $1.67(0.33)$ & 0.20 \\
\hline Minimum & $540(5800)$ & $2.90(0.57)$ & $2.74(0.54)$ & $\mathbf{3 . 2 6}(\mathbf{0 . 6 4})$ & 1.00 \\
\hline $10^{\text {th }}$ percentile & $990(10700)$ & $4.15(0.82)$ & $4.19(0.83)$ & $4.15(0.82)$ & 1.07 \\
\hline $25^{\text {th }}$ percentile & $\mathbf{1 6 4 0}(\mathbf{1 7} \mathbf{6 0 0})$ & $\mathbf{5 . 2 1}(1.03)$ & $5.63(1.11)$ & $\mathbf{4 . 9 9}(\mathbf{0 . 9 8})$ & 1.11 \\
\hline Median & $\mathbf{3 4 4 0}(\mathbf{3 7} \mathbf{0 0 0})$ & $\mathbf{6 . 7 8}(\mathbf{1 . 3 3})$ & $7.83(1.54)$ & $\mathbf{6 . 1 7}(\mathbf{1 . 2 2})$ & 1.25 \\
\hline $75^{\text {th }}$ percentile & $\mathbf{7 6 2 0}(\mathbf{8 2} \mathbf{1 0 0})$ & $\mathbf{8 . 4 5}(\mathbf{1 . 6 6})$ & $11.21(2.21)$ & $\mathbf{7 . 5 6}(\mathbf{1 . 4 9})$ & 1.28 \\
\hline $90^{\text {th }}$ percentile & $33780(363600)$ & $30.18(5.94)$ & $30.18(5.94)$ & $\mathbf{1 2 . 4 7 ( 2 . 4 5 )}$ & 1.85 \\
\hline Maximum & & & &
\end{tabular}

\begin{tabular}{|l|c|c|c|c|}
\hline & \multicolumn{2}{|c|}{ Design minimum outdoor air intake } & Minimum OA/ \\
\cline { 2 - 3 } & $\mathrm{L} / \mathrm{s}(\mathrm{cfm})$ per person & $\mathrm{L} / \mathrm{s}^{\circ} \mathrm{m}^{2}\left(\mathrm{cfm} / \mathrm{ft}^{2}\right)$ & $\begin{array}{c}\text { Occupant density } \\
\# / 100 \mathrm{~m}^{2}\left(1000 \mathrm{ft}^{2}\right)\end{array}$ \\
\hline \# of values & 74 & 76 & 76 & 137 \\
\hline Mean & $18.4(39.0)$ & $0.94(0.18)$ & 0.19 & $\mathbf{5 . 3 ( 4 . 9 )}$ \\
\hline Std. Dev. & $13.7(29.0)$ & $1.06(0.21)$ & 0.22 & $\mathbf{6 . 5}(\mathbf{6 . 1})$ \\
\hline Minimum & $1.3(2.9)$ & $0.17(0.03)$ & 0.06 & $0.9(0.8)$ \\
\hline $10^{\text {th }}$ percentile & $7.5(16.0)$ & $0.31(0.06)$ & 0.08 & $2.2(2.0)$ \\
\hline $25^{\text {th }}$ percentile & $10.6(22.4)$ & $0.42(0.08)$ & 0.10 & $2.9(2.7)$ \\
\hline Median & $15.2(32.1)$ & $0.60(0.12)$ & 0.12 & $\mathbf{3 . 9}(3.7)$ \\
\hline $75^{\text {th }}$ percentile & $23.6(50.0)$ & $0.92(0.18)$ & 0.15 & $5.9(5.4)$ \\
\hline $90^{\text {th }}$ percentile & $29.7(63.0)$ & $\mathbf{1 . 8 2}(0.36)$ & 0.31 & $\mathbf{8 . 0}(\mathbf{7 . 4})$ \\
\hline Maximum & $98.3(208.2)$ & $6.67(1.31)$ & 1.00 & $65.1(60.5)$ \\
\hline
\end{tabular}

Table 6 System design values

The mean value of the design minimum outdoor air intake per person is $18.4 \mathrm{~L} / \mathrm{s}(39.0 \mathrm{cfm})$, and the median is $15.2 \mathrm{~L} / \mathrm{s}(32.1 \mathrm{cfm})$. These values are above the minimum outdoor air requirement for office space in ASHRAE Standard 62-2001 (ASHRAE 2001) of $10 \mathrm{~L} / \mathrm{s}$ (20 cfm) per person. The design outdoor air intake in Table 6 is based on the number of workstations, since the number of occupants used in the design is not available. However, dividing the design minimum outdoor airflow by the number of occupants based on the occupant density in ASHRAE Standard 62-2001 (7 people per $\left.100 \mathrm{~m}^{2}\left(1000 \mathrm{ft}^{2}\right)\right)$ instead of the actual number of workstations yields a mean per person outdoor air intake of $13.1 \mathrm{~L} / \mathrm{s}(25.8 \mathrm{cfm})$ and a median of $8.5 \mathrm{~L} / \mathrm{s}(16.7 \mathrm{cfm})$, which are closer to the ASHRAE requirement. Note that design the minimum outdoor air intake is available for only 76 of the 141 systems. Also, these systems were designed at various times, and therefore it is not clear what standard or code requirements the systems were used in the design. The table also provides the design minimum outdoor air intake on a floor area basis. 
Finally, the mean ratio of the minimum outdoor air intake to supply airflow capacity is 0.18 and the median value is 0.12 , consistent with expected values of $10 \%$ to $20 \%$.

The mean value of the design occupant density in Table 6 is 5.3 people per $100 \mathrm{~m}^{2}(4.9$ per $\left.1000 \mathrm{ft}^{2}\right)$, while the median value is 3.9 per $100 \mathrm{~m}^{2}\left(3.7\right.$ per $\left.1000 \mathrm{ft}^{2}\right)$. As noted earlier when discussing the study spaces, these values for the individual air handlers are below the default value of 7 per $100 \mathrm{~m}^{2}\left(1000 \mathrm{ft}^{2}\right)$ in ASHRAE Standard 62-2001, but close to the default value of 5 per $100 \mathrm{~m}^{2}\left(1000 \mathrm{ft}^{2}\right)$ for office space in addendum $\mathrm{n}$ to the standard (ASHRAE 2003).

\begin{tabular}{|c|c|c|}
\hline System * & Issue & Comments \\
\hline AZHW10 (2 of 2) & $\begin{array}{l}\text { High supply capacity, } 24 \mathrm{~L} / \mathrm{s}^{\bullet} \mathrm{m}^{2} \\
\left(4.7 \mathrm{cfm} / \mathrm{ft}^{2}\right)\end{array}$ & System (1) at $8 \mathrm{~L} / \mathrm{s} \bullet \mathrm{m}^{2}\left(1.5 \mathrm{cfm} / \mathrm{ft}^{2}\right)$ \\
\hline LAGW05 (1 of 2) & $\begin{array}{l}\text { High supply capacity, } 18 \mathrm{~L} / \mathrm{s} \bullet \mathrm{m}^{2} \\
\left(3.6 \mathrm{cfm} / \mathrm{ft}^{2}\right)\end{array}$ & $\begin{array}{l}\text { System (2) at } 4 \mathrm{~L} / \mathrm{s} \bullet \mathrm{m}^{2}\left(0.7 \mathrm{cfm} / \mathrm{ft}^{2}\right) \\
\text { occupant density } 5 \text { times that of system (2); } \\
\text { floor area could be low }\end{array}$ \\
\hline MOCSO1 (1 of 1$)$ & $\begin{array}{l}\text { High supply capacity, } 27 \mathrm{~L} / \mathrm{s}^{\prime} \mathrm{m}^{2} \\
\left(5.3 \mathrm{cfm} / \mathrm{ft}^{2}\right)\end{array}$ & \\
\hline PABS04 (2 of 2) & $\begin{array}{l}\text { High supply capacity, } 25 \mathrm{~L} / \mathrm{s}^{\bullet} \mathrm{m}^{2} \\
\left(5.9 \mathrm{cfm} / \mathrm{ft}^{2}\right)\end{array}$ & System (1) at $4 \mathrm{~L} / \mathrm{s} \bullet \mathrm{m}^{2}\left(0.8 \mathrm{cfm} / \mathrm{ft}^{2}\right)$ \\
\hline CAEW09 (1 of 1$)$ & $\begin{array}{l}\text { High minimum outdoor air } 53 \mathrm{~L} / \mathrm{s} \\
(113 \mathrm{cfm}) \text { per person, }\end{array}$ & $\begin{array}{l}\text { Minimum outdoor air based on supply and } \\
\text { return capacities }\end{array}$ \\
\hline CAJS21 (2 of 2) & $\begin{array}{l}\text { High minimum outdoor air, } 98 \mathrm{~L} / \mathrm{s} \\
(208 \mathrm{cfm} \text { ) per person }\end{array}$ & $\begin{array}{l}100 \% \text { outdoor air system; System (1) at } 29 \\
\text { L/s }(61 \mathrm{cfm}) \text { per person }\end{array}$ \\
\hline MDDS01 (1 of 1) & $\begin{array}{l}\text { High minimum outdoor air, } 51 \mathrm{~L} / \mathrm{s} \\
(109 \mathrm{cfm}) \text { per person }\end{array}$ & \\
\hline NCDW03 (2 of 5) & $\begin{array}{l}\text { High minimum outdoor air, } 38 \mathrm{~L} / \mathrm{s} \\
(80 \mathrm{cfm}) \text { per person }\end{array}$ & $\begin{array}{l}\text { Other } 4 \text { systems from } 9 \mathrm{~L} / \mathrm{s}(20 \mathrm{cfm}) \text { per } \\
\text { person to } 16 \mathrm{~L} / \mathrm{s}(33 \mathrm{cfm}) \text { per person; } \\
\text { system }(2) \text { occupant density about } 25 \% \text { of } \\
\text { other } 4 \text { systems. }\end{array}$ \\
\hline NECW02 (1 of 1$)$ & $\begin{array}{l}\text { High minimum outdoor air, } 38 \mathrm{~L} / \mathrm{s} \\
(80 \mathrm{cfm}) \text { per person }\end{array}$ & $\begin{array}{l}\text { High occupant density, } 16 \text { occupants per } \\
100 \mathrm{~m}^{2}\left(1000 \mathrm{ft}^{2}\right)\end{array}$ \\
\hline TNFS10 ( 1 of 1$)$ & $\begin{array}{l}\text { High minimum outdoor air, } 34 \mathrm{~L} / \mathrm{s} \\
(72 \mathrm{cfm}) \text { per person }\end{array}$ & $\begin{array}{l}\text { Low occupant density, } 1.1 \text { occupants per } \\
100 \mathrm{~m}^{2}\left(1000 \mathrm{ft}^{2}\right)\end{array}$ \\
\hline CAJW25 (1 of 1) & $\begin{array}{l}\text { High occupant density, } 61 \\
\text { occupants per } 100 \mathrm{~m}^{2}\left(1000 \mathrm{ft}^{2}\right)\end{array}$ & $\begin{array}{l}\text { Supply airflow } 24 \mathrm{~L} / \mathrm{s}^{\bullet} \mathrm{m}^{2}\left(2.5 \mathrm{cfm} / \mathrm{ft}^{2}\right) \text {; } \\
\text { floor area could be low }\end{array}$ \\
\hline MOCS01 (1 of 1$)$ & $\begin{array}{l}\text { High occupant density, } 24 \\
\text { occupants per } 100 \mathrm{~m}^{z}\left(1000 \mathrm{ft}^{z}\right)\end{array}$ & \\
\hline NECW02 (1 of 1$)$ & $\begin{array}{l}\text { High occupant density, } 16 \\
\text { occupants per } 100 \mathrm{~m}^{2}\left(1000 \mathrm{ft}^{2}\right)\end{array}$ & \\
\hline SDBW02 (1 of 1$)$ & $\begin{array}{l}\text { High occupant density, } 38 \\
\text { occupants per } 100 \mathrm{~m}^{2}\left(1000 \mathrm{ft}^{2}\right)\end{array}$ & $\begin{array}{l}\text { Low minimum outdoor air } 1 \mathrm{~L} / \mathrm{s}(3 \mathrm{cfm}) \text { per } \\
\text { person, consistent with high occupant } \\
\text { density value }\end{array}$ \\
\hline TNDS05 (1 of 2$)$ & $\begin{array}{l}\text { High occupant density, just over } \\
12 \text { occupants per } 100 \mathrm{~m}^{2}\left(1000 \mathrm{ft}^{2}\right)\end{array}$ & System (2) lists no occupants \\
\hline
\end{tabular}

* Values in parentheses refers to air handler number relative to total number of air handlers, e.g. (2 of 2) means second of two air handlers serving the study space.

Table 7 System design outliers ${ }^{+}$

+ The text in the table noted with a strikethrough corresponds to two occurrences that are no longer outliers given the modifications to the data described earlier. 
The ventilation requirements in ASHRAE Standard 62-2001 were recently revised by addendum $\mathrm{n}$ to the standard (ASHRAE 2003). In the new procedure, the number of occupants is multiplied by an outdoor air requirement in units of $\mathrm{L} / \mathrm{s}(\mathrm{cfm})$ per person and the product is added to the floor area multiplied by a separate requirement in units of $\mathrm{L} / \mathrm{s} \bullet \mathrm{m}^{2}\left(\mathrm{cfm} / \mathrm{ft}^{2}\right)$. For office space these values are $2.5 \mathrm{~L} / \mathrm{s}(5 \mathrm{cfm})$ per person and $0.3 \mathrm{~L} / \mathrm{s} \bullet \mathrm{m}^{2}\left(0.06 \mathrm{cfm} / \mathrm{ft}^{2}\right)$. This method was used to determine the per person ventilation requirements of the study spaces based on the number of workstations and the floor area. Table 8 presents the results. Note that the mean outdoor air requirement is slightly lower than the $10 \mathrm{~L} / \mathrm{s}(20 \mathrm{cfm})$ per person requirement in Standard 622001, but the variation about the mean highlights the intended impact of occupant density.

\begin{tabular}{|l|c|}
\hline & $\begin{array}{c}\text { Study space outdoor air requirement } \\
\text { L/s (cfm) per person }\end{array}$ \\
\hline Mean & $\mathbf{9 . 0}(\mathbf{1 9 . 1})$ \\
\hline Std. Dev. & $\mathbf{3 . 3}(\mathbf{6 . 9})$ \\
\hline Minimum & $4.8(10.2)$ \\
\hline $10^{\text {th }}$ percentile & $\mathbf{6 . 5}(\mathbf{1 3 . 7})$ \\
\hline $25^{\text {th }}$ percentile & $7.2(15.3)$ \\
\hline Median & $8.7(18.3)$ \\
\hline $75^{\text {th }}$ percentile & $10.0(21.1)$ \\
\hline $90^{\text {th }}$ percentile & $\mathbf{1 2 . 1}(\mathbf{2 5 . 7 )}$ \\
\hline Maximum & $33.5(71.0)$ \\
\hline
\end{tabular}

Table 8 Study space outdoor air requirements based on Standard 62 addendum n

The system design values were examined to determine if there was a dependence on the year that the building was built. Figures 3 through 5 show the design supply airflow capacity, the design minimum outdoor air intake, and the occupant density, respectively, as a function of the year built. No clear trends are evident for any of these parameters, though there is a suggestion of lower supply airflows and occupant densities in newer buildings. Figures 3 and 4 show that more of the recent buildings employ VAV than CV systems, and that these VAV systems tend to have lower supply capacities as seen in Table 6. The supply air capacity was also examined as a function of the climate in which the building is located, as expressed by the number of heating and cooling degree days, but no relationship was evident.

The BASE protocol also obtained information on the frequency of a number of system maintenance activities. Table 9 summarizes the frequency of some inspection and maintenance activities that might impact ventilation airflows. Note that these frequencies are listed as the number of buildings, not the number of air handlers. Some of the less common frequencies, such as bi-weekly, are not included in the table. Also, not all of the buildings reported the inspection and maintenance items listed in the table. The air handler inspections appear to occur fairly often, but there is no information on the extent of these inspections. The other four activities are reported to occur much less often, particularly ductwork inspections and system testing, adjusting and balancing. The ratios of the measured airflows to design values were evaluated with respect to these frequencies, but no trends were evident. 


\begin{tabular}{|l|c|c|c|c|c|}
\hline Frequency & $\begin{array}{c}\text { Air handler } \\
\text { inspection }\end{array}$ & $\begin{array}{c}\text { Ductwork } \\
\text { inspection }\end{array}$ & $\begin{array}{c}\text { Controls } \\
\text { inspection }\end{array}$ & $\begin{array}{c}\text { Controls } \\
\text { recalibration }\end{array}$ & $\begin{array}{c}\text { Testing, } \\
\text { adjusting \& } \\
\text { balancing }\end{array}$ \\
\hline & \multicolumn{5}{|c|}{ Number of buildings } \\
\hline Daily & 14 & 0 & 14 & 0 & 0 \\
\hline Weekly & 5 & 0 & 2 & 0 & 0 \\
\hline Monthly & 23 & 1 & 4 & 4 & 0 \\
\hline Quarterly & 29 & 2 & 12 & 3 & 0 \\
\hline Semi-annually & 6 & 1 & 11 & 7 & 0 \\
\hline Annually & 3 & 4 & 14 & 10 & 3 \\
\hline As needed & 4 & 32 & 28 & 58 & 52 \\
\hline None & 0 & 59 & 12 & 15 & 43 \\
\hline
\end{tabular}

Table 9 Reported frequencies of selected system maintenance activities

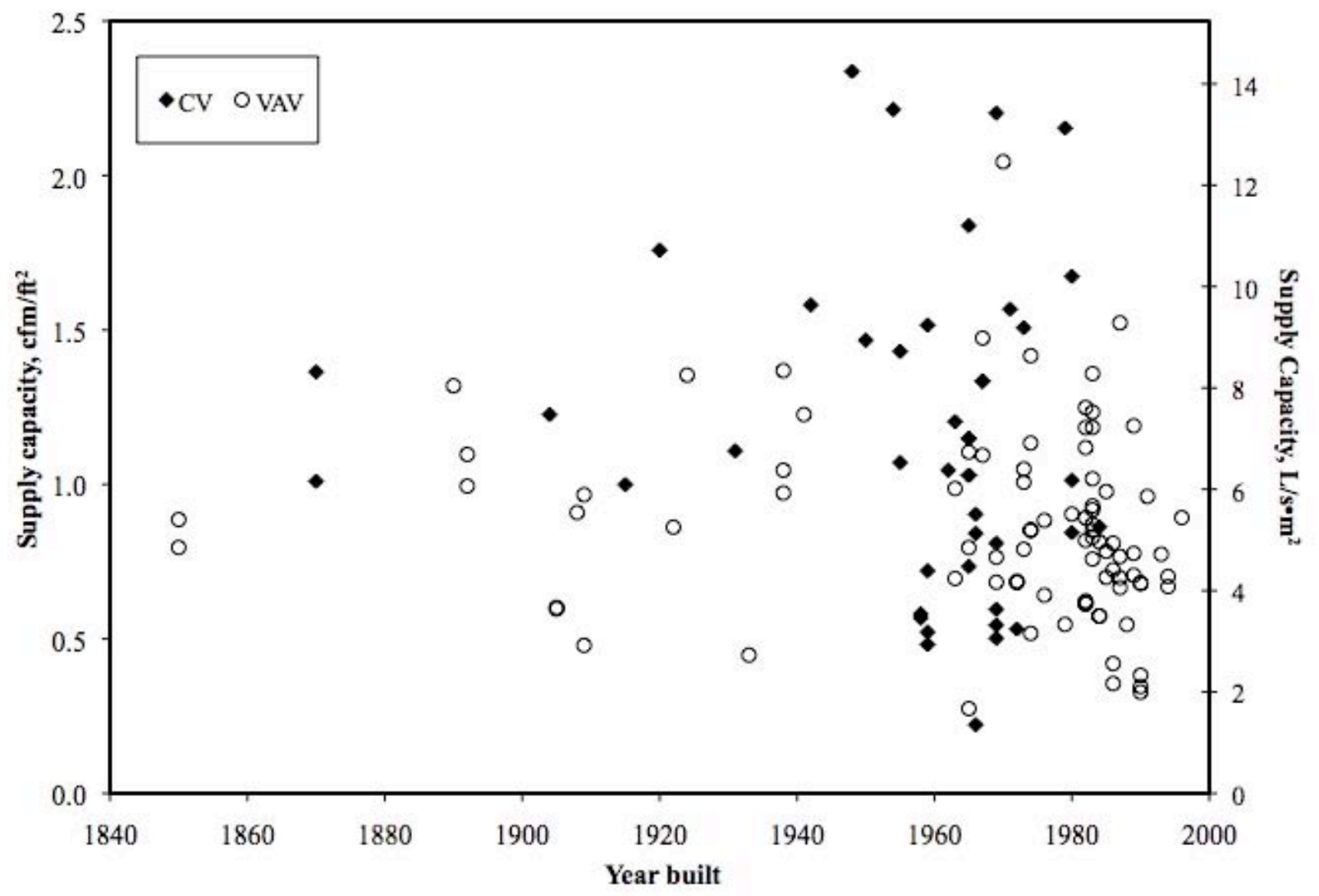

Figure 3 Design supply airflow capacity versus year built 


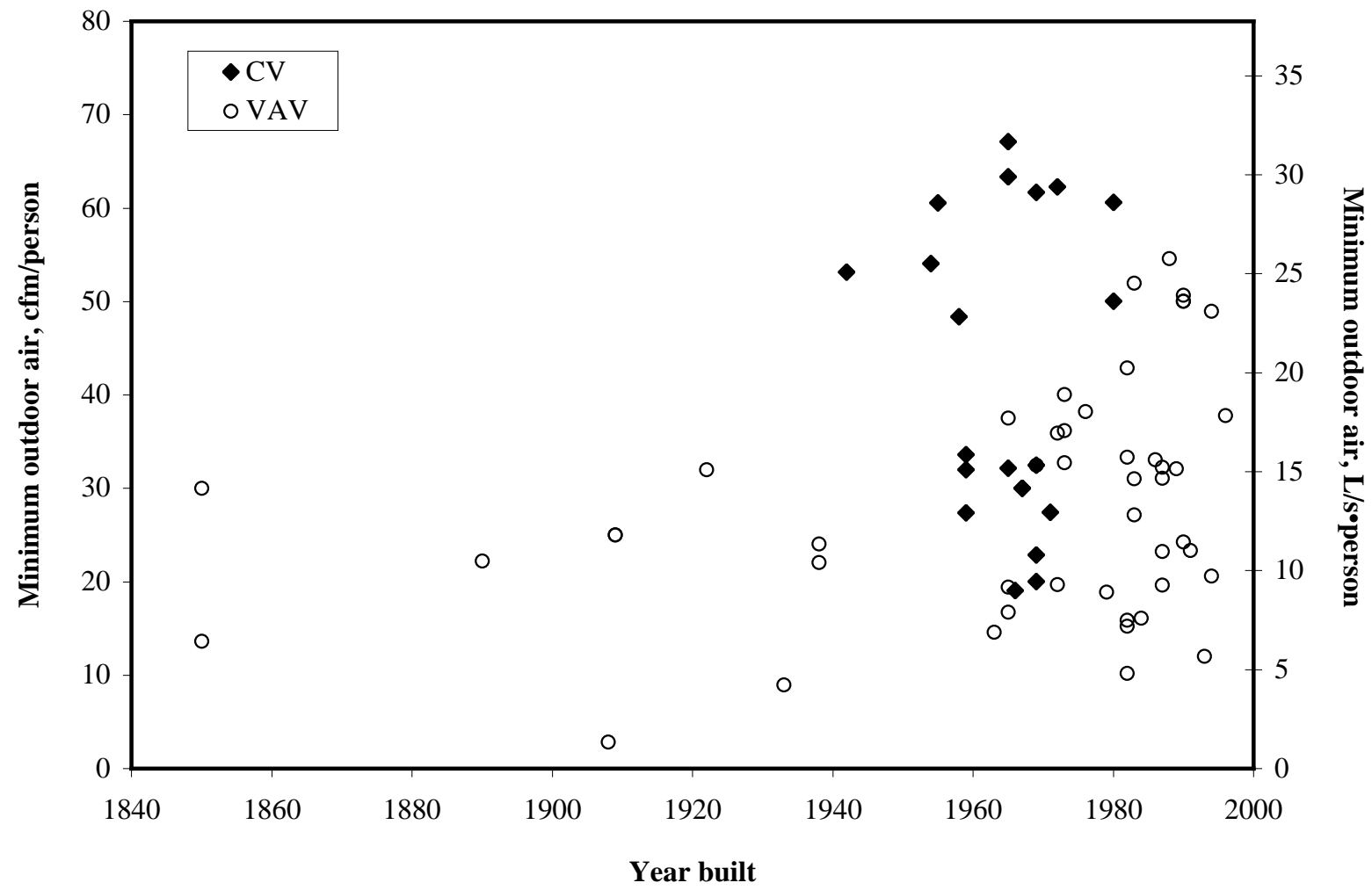

Figure 4 Design minimum outdoor air intake versus year built

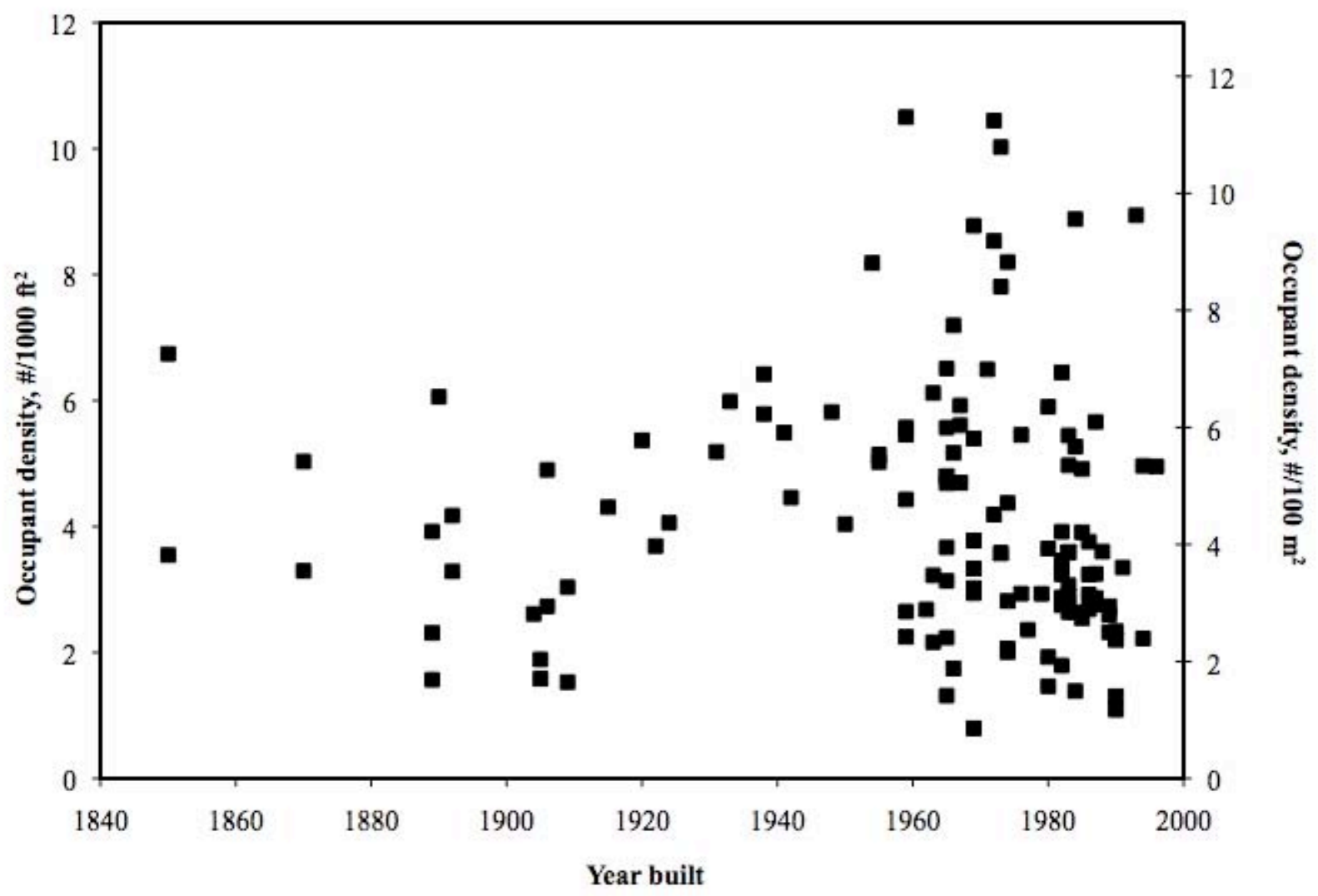

Figure 5 Design occupant density versus year built 


\subsection{Exhaust System Design and Building Airflow Balance}

In addition to the air handlers discussed in the last section, the 159 exhaust ventilation systems serving the study spaces were also considered in an attempt to examine the net design airflow into or out of the buildings. Table 10 presents a summary of the design information for the exhaust systems, which are predominantly toilet exhausts but also include kitchen exhaust, building relief and other fans. Design airflows are available for only 129 of the exhaust fans. Note that the individual airflows cover a wide range, with the maximum design airflow 500 times the minimum. The third column presents the design airflow normalized by floor area for the 126 systems for which the floor area served is available. (For toilet exhausts, the floor area is that of the toilet room.) While the variation in this normalized value is still large, it is less than for the airflows. The last column presents the normalized design airflows for only the toilet exhausts, which exhibit a smaller standard deviation than for all the exhaust fans.

\begin{tabular}{|l|c|c|c|}
\hline & \multicolumn{2}{|c|}{ All exhaust systems } & Toilet exhausts only \\
\hline & $\mathrm{L} / \mathrm{s}(\mathrm{cfm})$ & $\mathrm{L} / \mathrm{s} \bullet \mathrm{m}^{2}\left(\mathrm{cfm} / \mathrm{ft}^{2}\right)$ & $\mathrm{L} / \mathrm{s}^{\bullet} \mathrm{m}^{2}\left(\mathrm{cfm} / \mathrm{ft}^{2}\right)$ \\
\hline \# of values & 129 & 126 & 88 \\
\hline Mean & $2310(4880)$ & $14.9(2.94)$ & $14.3(2.81)$ \\
\hline Standard deviation & $3290(6960)$ & $21.8(4.28)$ & $13.2(2.59)$ \\
\hline Minimum & $40(90)$ & $0.6(0.13)$ & $0.7(0.14)$ \\
\hline $10^{\text {th }}$ percentile & $180(390)$ & $4.2(0.83)$ & $6.2(1.23)$ \\
\hline $25^{\text {th }}$ percentile & $400(850)$ & $6.8(1.34)$ & $7.5(1.47)$ \\
\hline Median & $950(2020)$ & $9.6(1.89)$ & $10.1(1.99)$ \\
\hline $75^{\text {th }}$ percentile & $2610(5530)$ & $15.0(2.96)$ & $16.0(3.15)$ \\
\hline $90^{\text {th }}$ percentile & $4990(10570)$ & $23.0(4.52)$ & $22.9(4.51)$ \\
\hline Maximum & $21250(45030)$ & $189.0(37.19)$ & $91.3(17.98)$ \\
\hline
\end{tabular}

Table 10 Summary of exhaust system design values

In addition to the exhaust fan design values, the net design airflow into, or out of, the buildings was also considered. The issue of interest is whether and to what extent these buildings are designed for positive pressurization, which is the typical design intent motivated by infiltration control, moisture transport through building envelopes and proper functioning of building exhaust fans. While the mean ratio of the supply to return design airflows for the study space air handlers in Table 6 is greater than one, this ratio does not include exhaust airflows and therefore does not describe the design airflow balance. In the BASE protocol, design values were obtained for air handler supply, return and outdoor airflows and for the exhaust fans serving the study spaces. These design values do not allow the determination of the net airflow for the building when there are other air handlers and exhaust fans. Therefore, a design airflow analysis for the whole building could only be performed for the six study spaces that correspond to an entire building. Table 11 presents the relevant design values for these buildings and the results of the net airflow analysis.

With only six buildings, and a lack of design data in some cases, the net building airflow can be calculated for only a small number of cases. The sixth column of Table 11 contains the design supply airflow minus the design return and exhaust airflows for the three buildings for which it could be calculated. This quantity describes the net airflow into the conditioned space of the building. For buildings CAEW09 and CAJS22, the values are positive and equal to $0.05 \mathrm{~L} / \mathrm{s}^{\bullet} \mathrm{m}^{2}$ $\left(0.23 \mathrm{cfm} / \mathrm{ft}^{2}\right)$ and $0.17 \mathrm{~L} / \mathrm{s} \bullet \mathrm{m}^{2}\left(0.85 \mathrm{cfm} / \mathrm{ft}^{2}\right)$ respectively. In building SDBW01 the value is 
negative but very small, $-0.01 \mathrm{~L} / \mathrm{s} \bullet \mathrm{m}^{2}\left(-0.05 \mathrm{cfm} / \mathrm{ft}^{2}\right)$, which is very close to a balance between the airstreams. The last column presents the balance between the air entering and leaving the building, i.e., the design minimum outdoor air intake minus the exhaust. Only four values can be determined, with three positive and one slightly negative. The three positive values, for buildings CAES09, CAJS22 and SDBW01 respectively, are $0.05 \mathrm{~L} / \mathrm{s}^{\bullet} \mathrm{m}^{2}\left(0.23 \mathrm{cfm} / \mathrm{ft}^{2}\right), 0.01 \mathrm{~L} / \mathrm{s} \bullet \mathrm{m}^{2}$ $\left(0.03 \mathrm{cfm} / \mathrm{ft}^{2}\right)$ and $0.01 \mathrm{~L} / \mathrm{s} \bullet \mathrm{m}^{2}\left(0.05 \mathrm{cfm} / \mathrm{ft}^{2}\right)$. The negative value is so close to zero that it indicates a balance between the minimum intake and exhaust airflows.

\begin{tabular}{|c|c|c|c|c|c|c|}
\hline \multirow[b]{2}{*}{ Building } & \multicolumn{4}{|c|}{ Design airflows, L/s (cfm) } & \multicolumn{2}{|c|}{ Net design airflow, L/s (cfm) } \\
\hline & Supply & Return & $\begin{array}{c}\text { Minimum } \\
\text { outdoor air }\end{array}$ & Exhaust & $\begin{array}{l}\text { Sup. - ret. } \\
\text { - exh. }\end{array}$ & MinOA - Exh. \\
\hline AZHS04 & $\begin{array}{c}11150 \\
(23610)\end{array}$ & No value & No value & $\begin{array}{c}8330 \\
(17640)\end{array}$ & - & -- \\
\hline CAEW09 & $\begin{array}{r}38730 \\
(82050) \\
\end{array}$ & $\begin{array}{c}30700 \\
(65040) \\
\end{array}$ & $\begin{array}{c}8030(17 \\
010)\end{array}$ & $\begin{array}{c}600 \\
(1280)\end{array}$ & $\begin{array}{c}7430 \\
(15730) \\
\end{array}$ & $\begin{array}{c}7430 \\
(15730) \\
\end{array}$ \\
\hline CAJS22 & $\begin{array}{c}8970 \\
(19010)\end{array}$ & No value & $\begin{array}{c}1040 \\
(2200)\end{array}$ & $\begin{array}{c}780 \\
(1650)\end{array}$ & $\begin{array}{c}8190(17 \\
360)\end{array}$ & $\begin{array}{c}260 \\
(550)\end{array}$ \\
\hline SDBW01 & $\begin{array}{c}9920 \\
(21010) \\
\end{array}$ & $\begin{array}{c}9590 \\
(20310) \\
\end{array}$ & $\begin{array}{c}1500 \\
(3170)\end{array}$ & $\begin{array}{c}920 \\
(1950) \\
\end{array}$ & $\begin{array}{c}-590 \\
(-1250) \\
\end{array}$ & $\begin{array}{c}580 \\
(1220)\end{array}$ \\
\hline TNFS08 & $\begin{array}{c}8640 \\
(18310) \\
\end{array}$ & No value & $\begin{array}{c}590 \\
(1250) \\
\end{array}$ & $\begin{array}{c}600 \\
(1260) \\
\end{array}$ & -- & $\begin{array}{l}-10 \\
(-10) \\
\end{array}$ \\
\hline TXFS02 & $\begin{array}{c}17000 \\
(36020)\end{array}$ & No value & No value & No value & -- & -- \\
\hline
\end{tabular}

Table 11 Net design airflow analysis

\subsection{Measured Occupant Density}

The actual number of occupants was counted at least four times in each study space. Table 12 summarizes these observations. These data show that on average the actual occupancy is about $80 \%$ of the design occupancy as defined by the number of work stations, corresponding to a mean occupant density of 4.0 people per $100 \mathrm{~m}^{2}\left(3.7\right.$ per $\left.1000 \mathrm{ft}^{2}\right)$. The occupant density data were also analyzed for only those times when the ventilation parameters were measured, typically on Wednesday and Thursday of the test week. There were 388 such values, but the summary statistics are essentially identical to those seen in Table 11.

\begin{tabular}{|l|c|c|}
\hline & $\begin{array}{c}\text { Measured occupant density, } \\
\# / 100 \mathrm{~m}^{2}\left(\# / 1000 \mathrm{ft}^{2}\right)\end{array}$ & $\begin{array}{c}\text { Measured density/Number } \\
\text { of work stations }\end{array}$ \\
\hline \# of values & 824 & 824 \\
\hline Mean & $4.0(3.7)$ & 0.78 \\
\hline Standard deviation & $1.7(1.6)$ & 0.24 \\
\hline Minimum & $0.9(0.9)$ & 0.24 \\
\hline $10^{\text {th }}$ percentile & $2.3(2.2)$ & 0.57 \\
\hline $25^{\text {th }}$ percentile & $2.8(2.6)$ & 0.65 \\
\hline Median & $3.6(3.3)$ & 0.76 \\
\hline $75^{\text {th }}$ percentile & $5.0(4.6)$ & 0.87 \\
\hline $90^{\text {th }}$ percentile & $6.3(5.9)$ & 0.98 \\
\hline Maximum & $11.1(10.3)$ & 3.13 \\
\hline
\end{tabular}

Table 12 Summary of measured occupant density 


\subsection{Ventilation System Performance Measurements}

This section presents the ventilation system performance measurement results for the air handlers serving the study spaces and for the study spaces themselves. There were 562 ventilation measurement events, that is, the total number of times that some or all of the ventilation measurements were made on the study space air handlers. These measurements cover 97 of the 100 BASE buildings, excluding the three naturally ventilated buildings. Appendix C lists a number of cases where measurement issues associated with the volumetric airflow measurements were identified, along with any adjustments that were made to account for these issues. The measurements are presented in Appendix D for the air handlers and Appendix E for the study spaces. Each measured value in these appendices is presented with an uncertainty estimate associated with the value. The naturally ventilated buildings are discussed in conjunction with the outdoor air ventilation estimated using peak $\mathrm{CO}_{2}$ concentrations in section 3.5.4.

\subsubsection{Supply Airflow}

Of the 562 measurement events, 495 included measurements of the system supply airflow. In some cases, the supply airflow is estimated by adding the outdoor air intake and the recirculation airflow, resulting in a total of 536 measured supply airflow values. As noted earlier, the uncertainty associated with the supply airflow measurements was estimated to equal $10 \%$. When the supply airflow is based on the sum of the outdoor and recirculation airflows, the uncertainty in the supply airflow is about $25 \%$, based on a $30 \%$ uncertainty in the outdoor airflow and $10 \%$ in the recirculation flow.

The measured supply airflows are compared with the design supply capacities in the 512 cases where a design value exists. The mean value of the ratio of the measured supply airflow to the design value is 0.83 . The mean is 0.72 for the VAV systems and 1.07 for the CV systems. The VAV systems are expected to have a lower ratio of measured to design, since these systems modulate the supply airflow in response to internal loads. Figure 6 is a plot of the measured to design ratio against outdoor temperature. Note that for the VAV systems, the ratio decreases for outdoor temperatures below about $15^{\circ} \mathrm{C}\left(59^{\circ} \mathrm{F}\right)$, presumably due to the lower cooling loads at these temperatures. The $\mathrm{CV}$ data points exhibit little dependence on outdoor temperature. Four $\mathrm{CV}$ points have a ratio of about 4.5 , which all correspond to the single air handler serving study space CAJS03. This air handler has the lowest design value of supply airflow capacity per unit floor area, and it is possible that the design value is in error or out of date. The mean ratio of measured to design for CV systems is reduced from 1.07 to 0.98 without these four values.

The supply airflows for the air handlers were combined to determine the supply airflow to each study space. These supply airflows were then divided by the study space floor area (B1AREA), and the results are summarized in Table 13 and plotted versus outdoor air temperature in Figure 7. Both the table and the figure distinguish between VAV and CV systems. The values of the study space supply airflow per unit floor area range from $\mathbf{0 . 8 8} \mathbf{L} / \mathbf{s}^{\bullet} \mathbf{m}^{2}\left(0.17 \mathrm{cfm} / \mathrm{ft}^{2}\right)$ to $21.11 \mathrm{~L} / \mathrm{s} \bullet \mathrm{m}^{2}\left(4.15 \mathrm{cfm} / \mathrm{ft}^{2}\right)$. The mean value for all the systems is $\mathbf{5 . 1 2} \mathbf{~ L / s} \cdot \mathbf{m}^{2}\left(\mathbf{1 . 0 1} \mathbf{~ c f m} / \mathbf{f t}^{2}\right)$; the mean uncertainty is $16 \%$ of the measured value, and the maximum is $31 \%$. As expected, the VAV systems have lower supply airflows than the CV systems, and the dependence on outdoor temperature is similar to that seen in Figure 6. Note that the high points in Figure 7 do not correspond to the high points in Figure 6. The eight points in Figure 7 greater than $15 \mathrm{~L} / \mathrm{s}^{\bullet} \mathrm{m}^{2}$ $\left(3 \mathrm{cfm} / \mathrm{ft}^{2}\right)$ correspond to cases with high design supply airflows (CAES17 and LAGW05). 


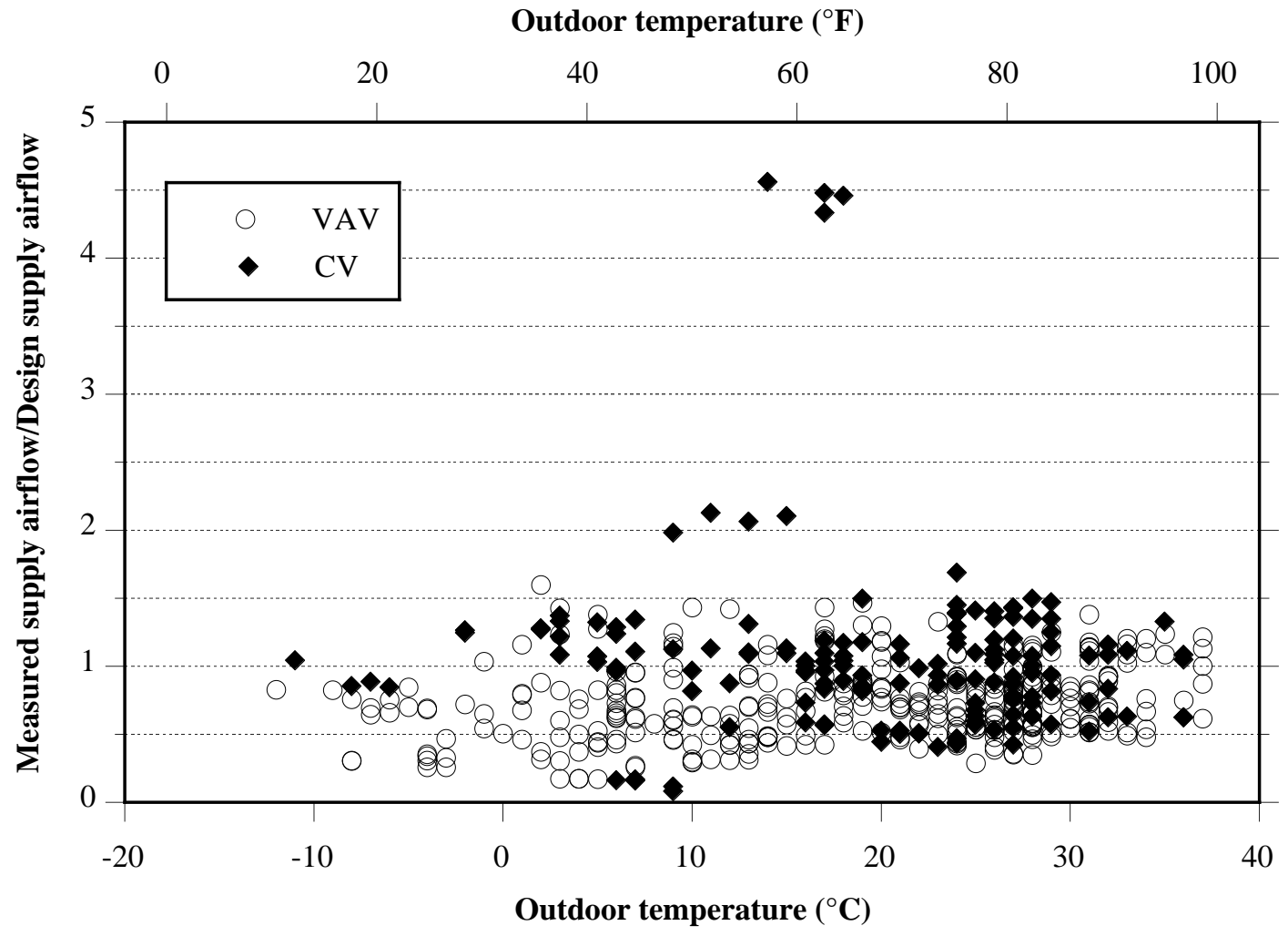

Figure 6 Ratio of measured to design supply airflow versus outdoor temperature

\begin{tabular}{|l|c|c|c|}
\hline & \multicolumn{3}{|c|}{$\begin{array}{c}\text { Supply airflow/Floor area } \\
\mathrm{L} / \mathrm{s}^{\circ} \mathrm{m}^{2}\left(\mathrm{cfm} / \mathrm{ft}^{2}\right)\end{array}$} \\
\hline & All systems & VAV & $\mathrm{CV}$ \\
\hline \# of values & 384 & 289 & 95 \\
\hline Mean & $\mathbf{5 . 1 2}(\mathbf{1 . 0 1})$ & $\mathbf{4 . 5 5}(\mathbf{0 . 9 0})$ & $6.86(1.35)$ \\
\hline Std. Dev. & $\mathbf{3 . 0 2}(\mathbf{0 . 5 9})$ & $\mathbf{2 . 6 2}(\mathbf{0 . 5 2})$ & $3.46(0.68)$ \\
\hline Minimum & $0.88(0.17)$ & $0.88(0.17)$ & $1.80(0.35)$ \\
\hline $10^{\text {th }}$ percentile & $\mathbf{2 . 1 6}(\mathbf{0 . 4 3})$ & $\mathbf{2 . 1 2}(\mathbf{0 . 4 2})$ & $2.25(0.44)$ \\
\hline $25^{\text {th }}$ percentile & $\mathbf{2 . 9 9}(\mathbf{0 . 5 9})$ & $\mathbf{2 . 8 9}(\mathbf{0 . 5 7})$ & $4.82(0.95)$ \\
\hline Median & $\mathbf{4 . 6 9}(\mathbf{0 . 9 2})$ & $\mathbf{4 . 3 0}(\mathbf{0 . 8 5})$ & $5.72(1.13)$ \\
\hline $75^{\text {th }}$ percentile & $\mathbf{6 . 2 5}(\mathbf{1 . 2 3})$ & $\mathbf{5 . 6 9}(\mathbf{1 . 1 2})$ & $9.04(1.78)$ \\
\hline $90^{\text {th }}$ percentile & $\mathbf{8 . 4 7}(\mathbf{1 . 6 7})$ & $\mathbf{7 . 1 9}(\mathbf{1 . 4 1})$ & $11.34(2.23)$ \\
\hline Maximum & $21.11(4.15)$ & $21.11(4.15)$ & $16.24(3.20)$ \\
\hline
\end{tabular}

Table 13 Summary of measured supply airflows 


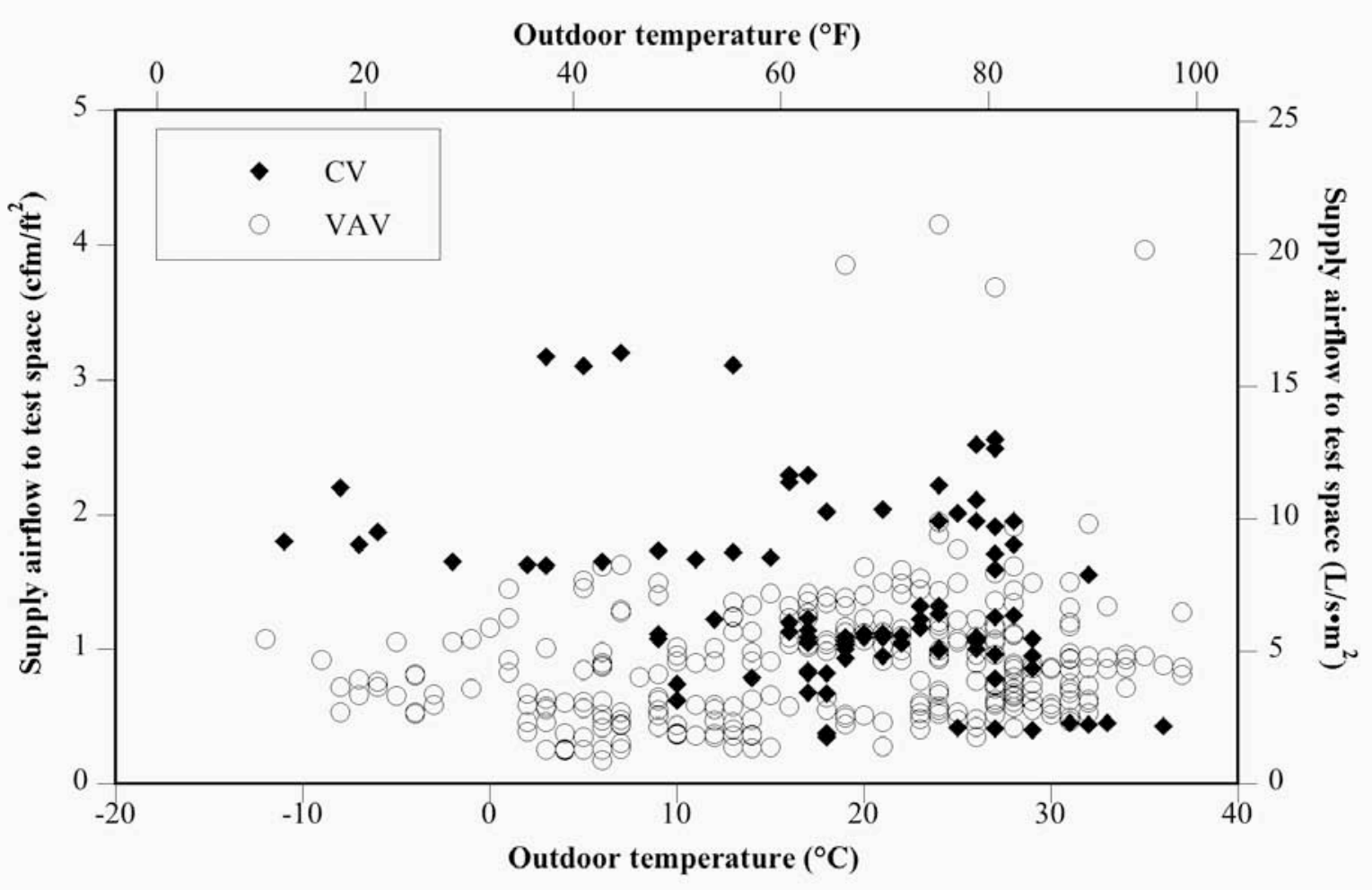

Figure 7 Measured study space supply airflow versus outdoor temperature

\subsubsection{Outdoor Air Fraction}

The outdoor air fraction (i.e., the outdoor air intake divided by the supply airflow) was determined in two ways, dividing the measured outdoor airflow by the measured supply airflow and second through the measurement of $\mathrm{CO}_{2}$ concentrations in the outdoor, supply and recirculation airstreams. The former determination is referred to as the volumetric value, while the latter is referred to as the $\mathrm{CO}_{2}$ ratio value. The volumetric outdoor air fraction was determined for each air handler test based on whichever of the expressions in Equations (1a), (1b) and (1c), described in section 2.2, apply. For some air handlers, the value of $F_{o}$ could be determined using more than one of the expressions. Of the 562 air handler test events, there were 350 values of $F_{o}$ based on $Q_{O}$ divided by $Q_{S}$ (Equation 1a), 125 based on $\left(Q_{S}\right.$ minus $Q_{R}$ ) divided by $\mathrm{Q}_{\mathrm{S}}\left(\right.$ Equation $1 \mathrm{~b}$ ) and 57 based on $\mathrm{Q}_{\mathrm{O}}$ divided by ( $\mathrm{Q}_{\mathrm{O}}$ plus $\mathrm{Q}_{\mathrm{R}}$ ) (Equation 1c). As noted earlier, in some cases when Equation (1b) was applied, the value of $\mathrm{Q}_{\mathrm{R}}$ was greater than $\mathrm{Q}_{\mathrm{S}}$, but the difference was never significantly different from zero. In those cases, the outdoor airflow and outdoor air fraction are both set equal to zero. For each determination of the outdoor air fraction, the uncertainty is calculated based on the uncertainties in $\mathrm{Q}_{\mathrm{O}}, \mathrm{Q}_{\mathrm{S}}$ and $\mathrm{Q}_{\mathrm{R}}$. When $\mathrm{F}_{\mathrm{o}}$ can be determined using more than one of these expressions, the value of $\mathrm{F}_{\mathrm{o}}$ with the lowest uncertainty is identified and referred to as the best volumetric value of $\mathrm{F}_{\mathrm{o}}$. The outdoor air fraction was also determined using $\mathrm{CO}_{2}$ concentrations measured in the outdoor, supply and recirculation airstreams using Equation (2).

Table 14 summarizes the measured outdoor air fractions for both the volumetric and $\mathrm{CO}_{2}$ methods. Some of the volumetric values are greater than $100 \%$, which does not make physical sense. However, in all of these cases but one, the uncertainty around the value includes $100 \%$ outdoor air. That single value is not included in Table 14 or the subsequent analysis, but it is included in Appendix D. The mean volumetric outdoor air fraction is $\mathbf{0 . 3 8}$, and the mean $\mathrm{CO}_{2}$ 
value is 0.31 . The mean uncertainty in the volumetric outdoor air fraction is 0.16 , while the maximum uncertainty is 0.44 . The uncertainties in the $\mathrm{CO}_{2}$-based values tend to be larger, with a mean uncertainty of 0.60 (roughly twice the mean outdoor air fraction) and several values as high as 2 to 4 in units of outdoor air fraction.

\begin{tabular}{|l|c|c|}
\hline & Best volumetric & Carbon dioxide \\
\hline \# of values & $\mathbf{5 0 9}$ & 520 \\
\hline Mean & $\mathbf{0 . 3 8}$ & 0.31 \\
\hline Standard deviation & 0.35 & 0.27 \\
\hline Minimum & 0.00 & 0.00 \\
\hline $10^{\text {th }}$ percentile & 0.04 & 0.03 \\
\hline $25^{\text {th }}$ percentile & 0.10 & 0.11 \\
\hline Median & 0.22 & 0.23 \\
\hline $75^{\text {th }}$ percentile & 0.59 & 0.44 \\
\hline $90^{\text {th }}$ percentile & 1.00 & 0.75 \\
\hline Maximum & $\mathbf{1 . 5 2}$ & 1.20 \\
\hline
\end{tabular}

Table 14 Summary of measured outdoor air fraction

Figure 8 is a plot of the outdoor air fraction against outdoor air temperature, with systems having economizer cycles distinguished from those that do not. Note that most of the low outdoor air intake values, i.e., outdoor air fractions below about 0.25 , correspond to temperatures greater than $20^{\circ} \mathrm{C}\left(68^{\circ} \mathrm{F}\right)$. As expected, systems with economizer cycles tend to have higher outdoor air fractions at milder temperatures than systems without economizers; the non-economizer systems also tend to operate more consistently at lower outdoor air fractions. However, there are some exceptions to this general dependence, which could be due to a variety of causes such as the temperature and humidity sensors used to control the economizers being out of calibration. The dependence of outdoor air fraction on outdoor temperature leads one to expect that minimum outdoor air intake conditions are more likely to exist at these warmer temperatures than under colder conditions, which has implications for planning field evaluations of ventilation system performance.

Figure 9 is a plot of the outdoor air fraction against outdoor temperature for an idealized economizer cycle. It shows that such a system operates at minimum outdoor air at cold and hot temperatures, less than $0{ }^{\circ} \mathrm{C}\left(32^{\circ} \mathrm{F}\right)$ and greater than $20^{\circ} \mathrm{C}\left(68^{\circ} \mathrm{F}\right)$, though these particular values are only examples. In between these two temperatures, the system uses outdoor air to cool the building, with a lower outdoor air fraction as the temperature gets colder. Figure 10 is a plot of whole building air change rates measured with the tracer gas decay method plotted against outdoor air temperature from a previous study (Persily et al. 1992). These data clearly exhibit the pattern seen in Figure 9. While the data in Figure 8 suggest the same pattern and are consistent with expected variations due to economizer operation, note that the actual data include typically four points for each building generally over a narrow temperature range and not all the buildings have economizer cycles. 


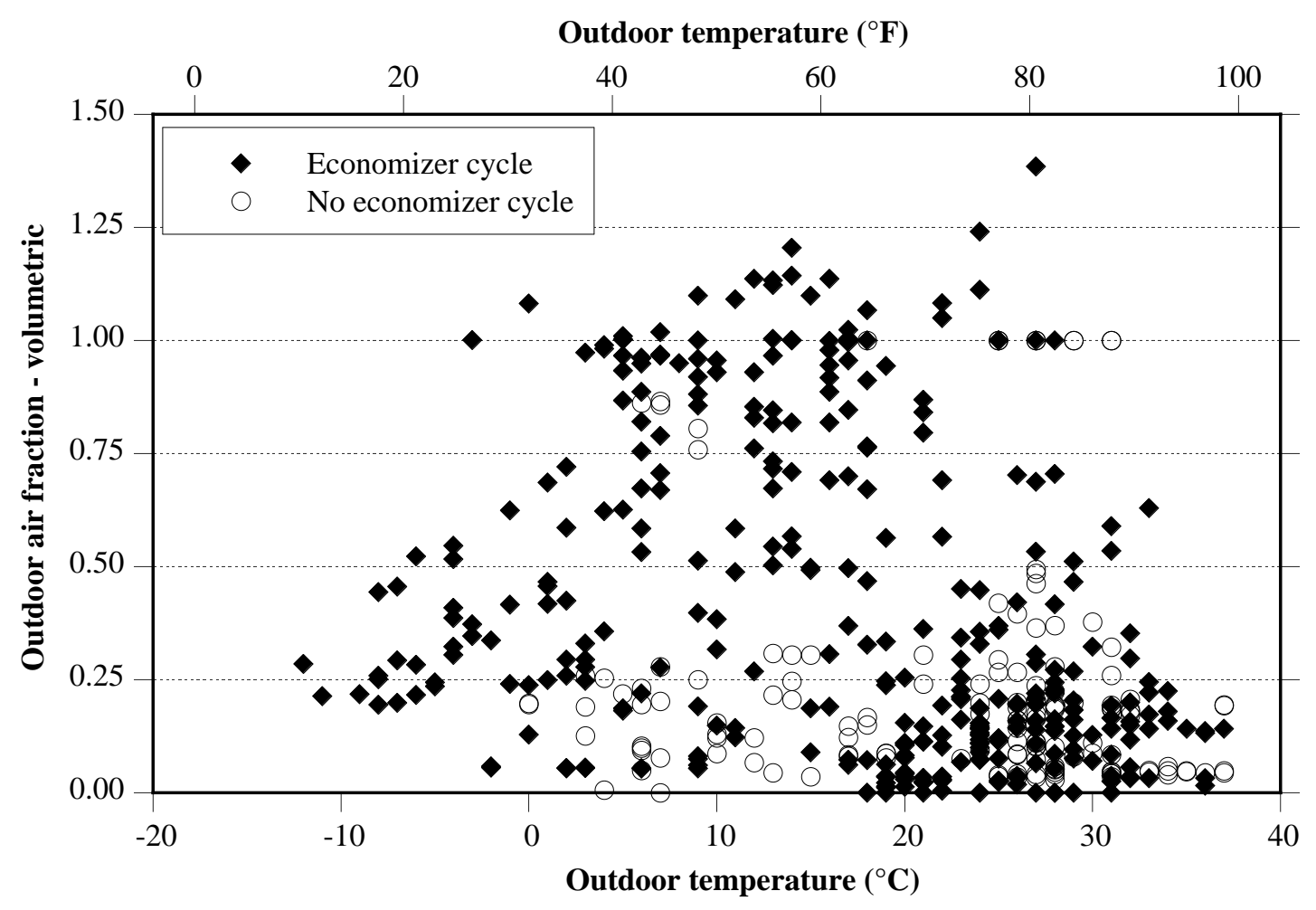

Figure 8 Volumetric outdoor air fraction versus outdoor temperature

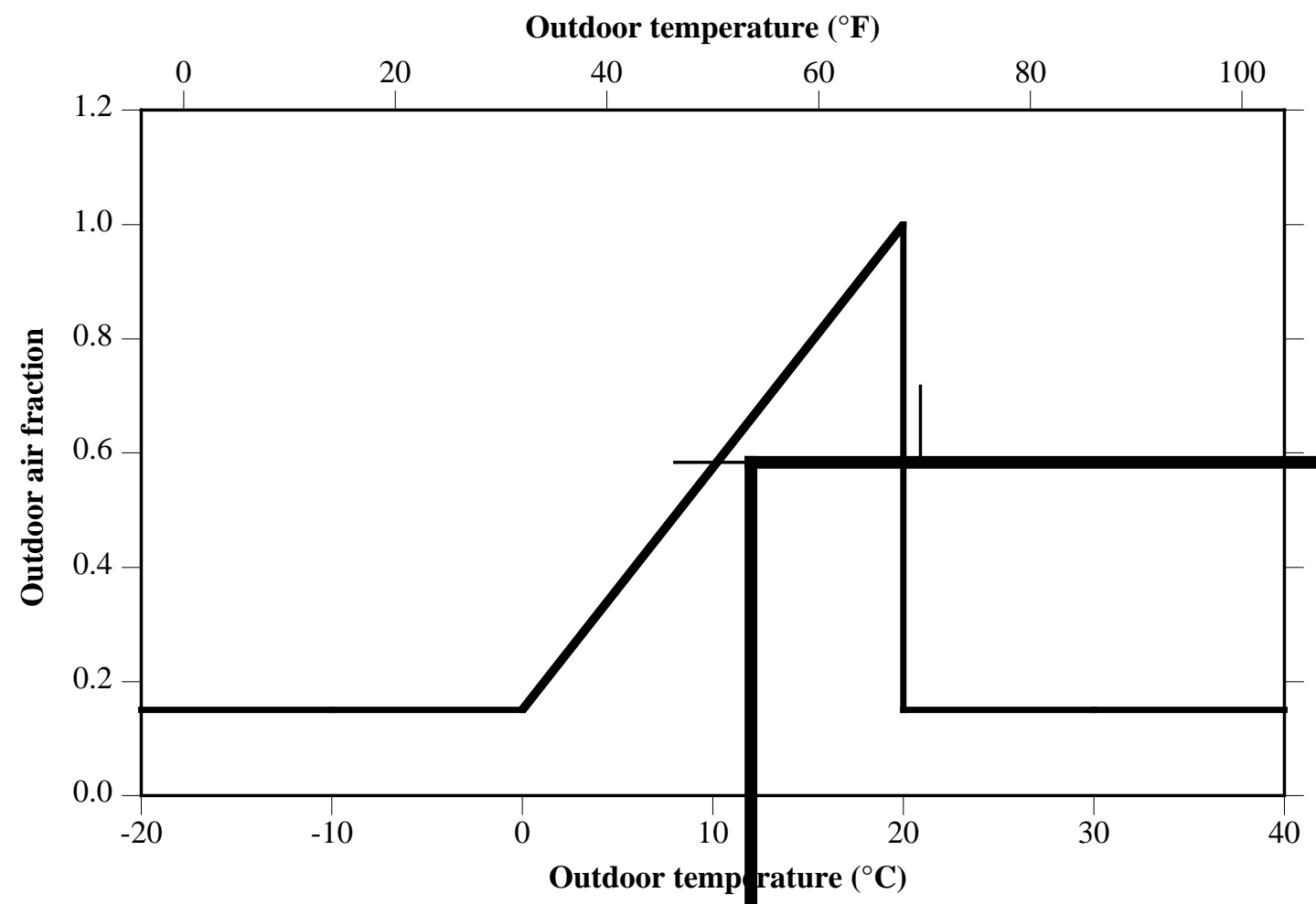

Figure 9 Outdoor air fraction for an idealized economizer cycle 


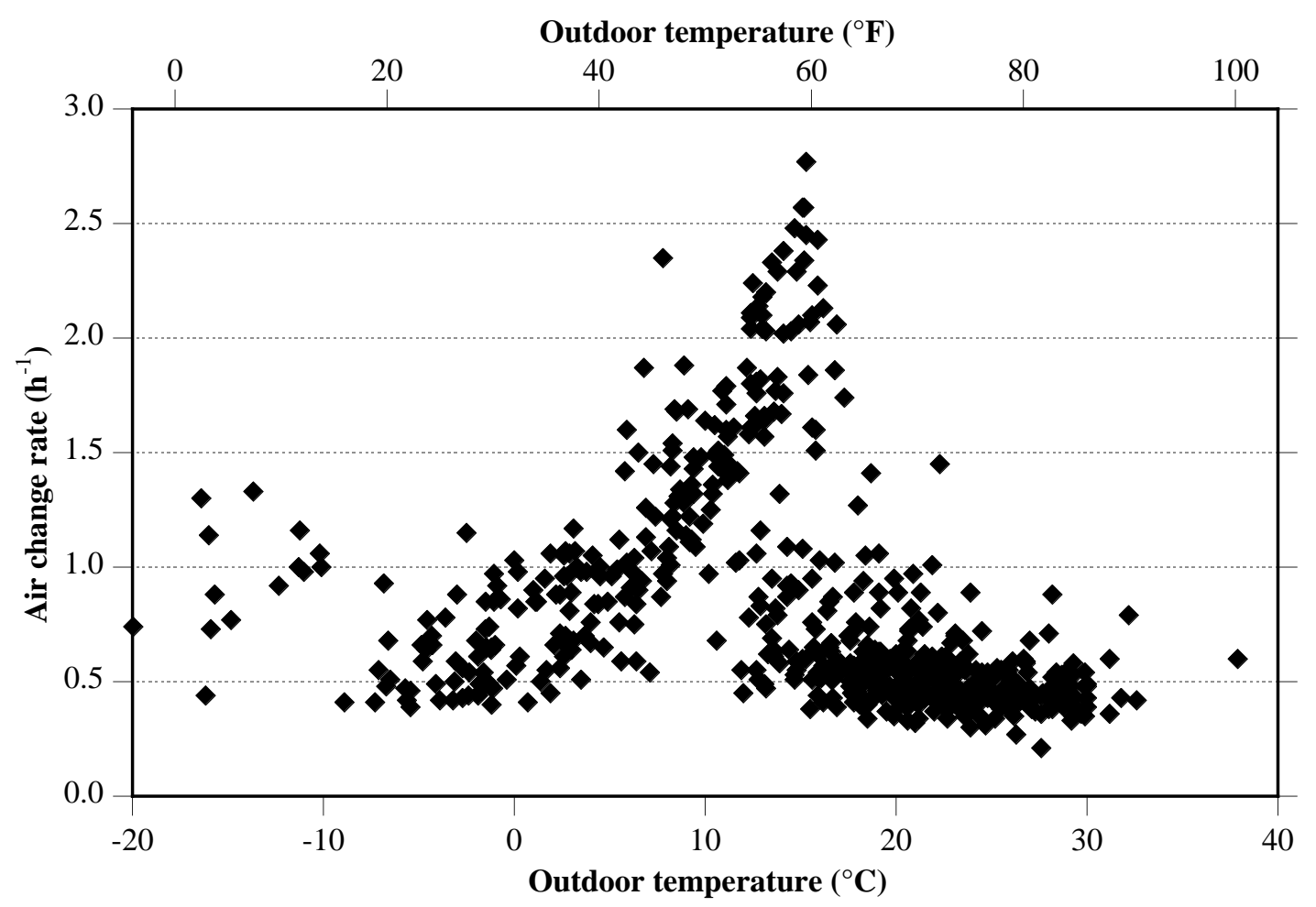

Figure 10 Measured air change rates versus outdoor air temperature (Persily et al. 1992)

As noted earlier, the uncertainties in the $\mathrm{CO}_{2}$-based outdoor air fractions tend to be larger than the uncertainties in the volumetric values. The $\mathrm{CO}_{2}$ uncertainties are based on the concentration measurement uncertainty of $90 \mathrm{mg} / \mathrm{m}^{3}(50 \mathrm{ppm}(\mathrm{v}))$. The larger uncertainties in the $\mathrm{CO}_{2}$ values occur due to the magnitude of the concentration measurement uncertainty relative to the concentration differences in Equation 2. The difference between $C_{R}$ and $C_{O}$, relative to the concentration measurement uncertainty, is the primary determinant of the uncertainty in $\mathrm{F}_{\mathrm{o}}$. Figure 11 is a plot of the $\mathrm{CO}_{2}$ concentration difference between the recirculation and outdoor airstream versus time of day at which the concentration measurements began. The average concentration difference is $391 \mathrm{mg} / \mathrm{m}^{3}(217 \mathrm{ppm}(\mathrm{v}))$, with a mean difference for measurements before noon of $418 \mathrm{mg} / \mathrm{m}^{3}(232 \mathrm{ppm}(\mathrm{v}))$ and an afternoon mean of $369 \mathrm{mg} / \mathrm{m}^{3}(205 \mathrm{ppm}(\mathrm{v}))$. Given that the concentration measurement uncertainty of $90 \mathrm{mg} / \mathrm{m}^{3}(50 \mathrm{ppm}(\mathrm{v}))$ is equal to $25 \%$ of the mean concentration difference, it is not surprising that the values of $\mathrm{F}_{\mathrm{o}}$ based on $\mathrm{CO}_{2}$ are so imprecise.

In making these measurements, the same $\mathrm{CO}_{2}$ monitor was used to measure the concentration in the three airstreams over a relatively short period of time. Therefore, it is reasonable to expect that the uncertainty is lower for the differential $\mathrm{CO}_{2}$ concentrations in Equation 2 than for the absolute concentrations. The uncertainties in the $\mathrm{CO}_{2}$ outdoor air fractions were recalculated using an uncertainty of $90 \mathrm{mg} / \mathrm{m}^{3}(50 \mathrm{ppm}(\mathrm{v}))$ for the differential concentrations. The mean uncertainty was reduced from 0.60 to 0.42 , and the median value of the uncertainty decreased from 0.43 to 0.31 . It is not possible to estimate the actual uncertainty in the differential concentrations after the fact, though it is likely to be less than for the absolute concentrations. Nonetheless, the form of the equation used to determine $\mathrm{F}_{\mathrm{o}}$ from $\mathrm{CO}_{2}$ concentrations makes it advantageous to perform the uncertainty calculations based on the uncertainty in the differential concentration and also implies that one can tolerate some zero drift in the $\mathrm{CO}_{2}$ monitor without a large degradation in accuracy. 


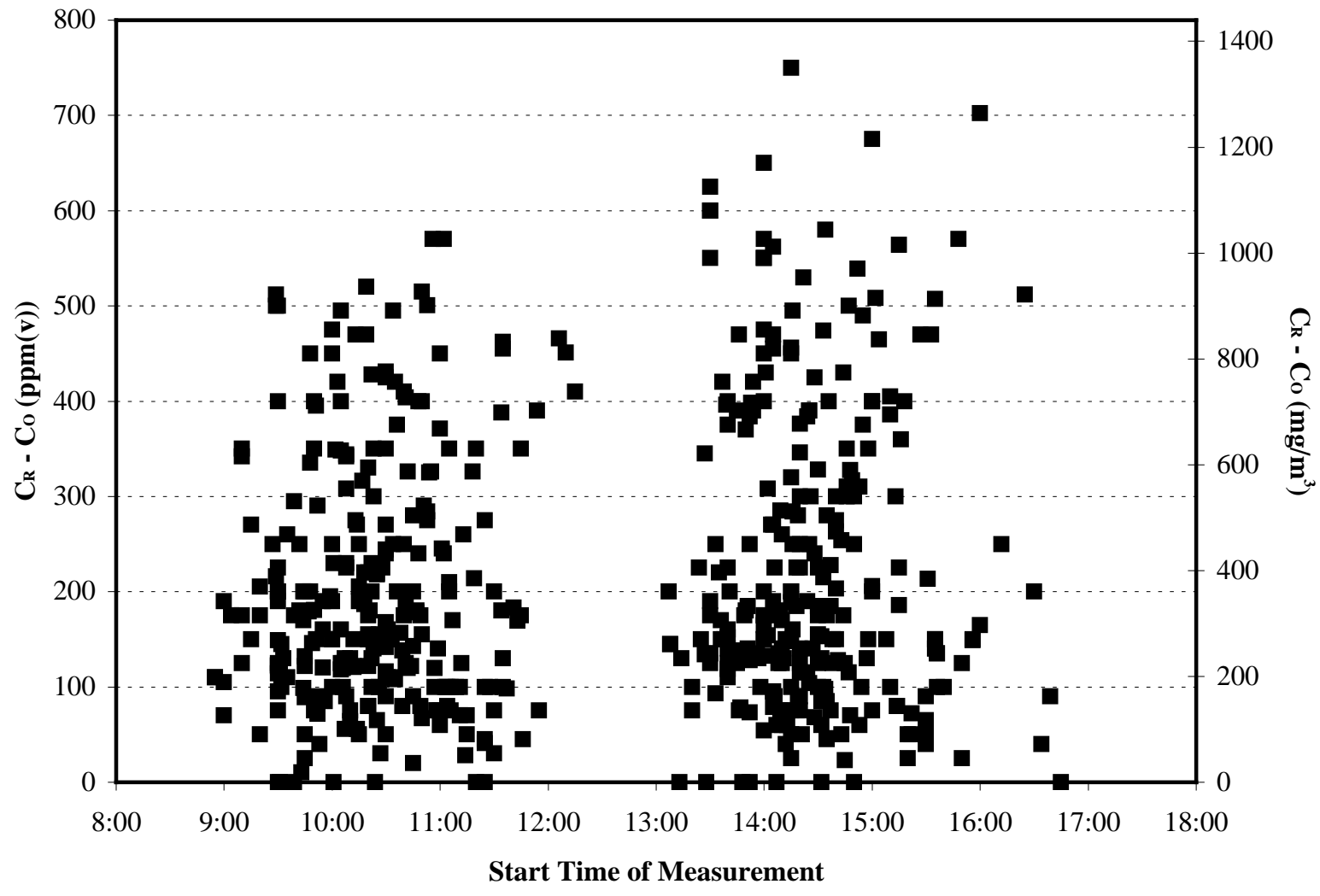

Figure 11 Return minus outdoor air $\mathrm{CO}_{2}$ concentration versus time of day

Figure 12 is a plot of $\mathrm{F}_{\mathrm{o}}$ based on $\mathrm{CO}_{2}$ versus the volumetric value. This comparison shows that despite the high level of uncertainty in the $\mathrm{CO}_{2}$ values, they are generally consistent with those based on volumetric airflows. The line in the plot corresponds to perfect agreement between the two parameters and is not a curve fit to the data. A linear regression of the $\mathrm{CO}_{2}$ to the volumetric values yields a slope of 0.61 and an r-squared of 0.58 . 


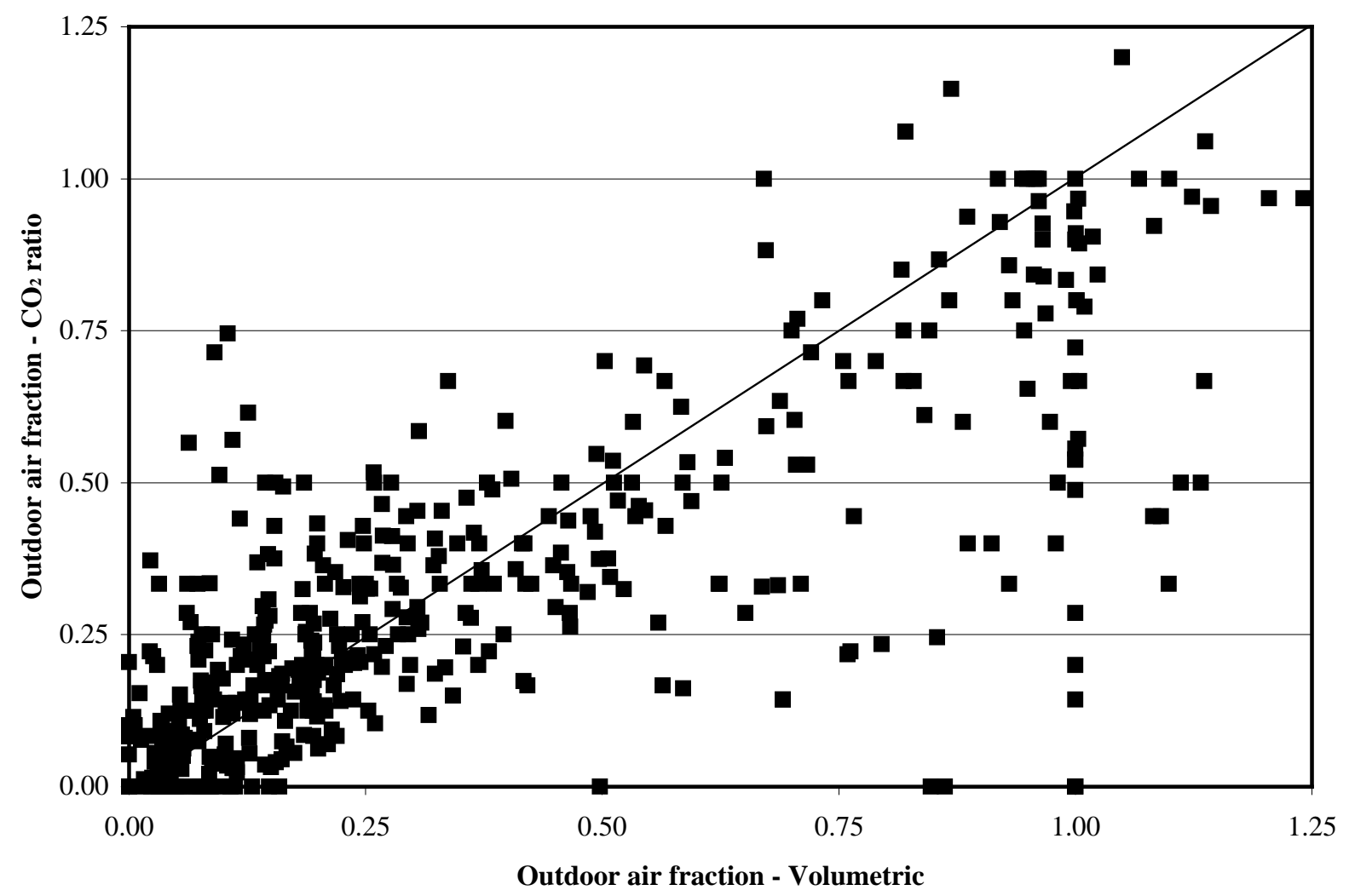

Figure 12 Outdoor air fraction based on $\mathrm{CO}_{2}$ versus volumetric 


\subsubsection{Outdoor Air Ventilation}

Of the 562 measurement events, 510 included traverse measurements, or estimates based on the difference between the supply and recirculation airflow, of the system outdoor air intake. The measured outdoor airflows are compared with the design minimum outdoor air intakes for the 274 cases where such a design value exists. Figure 13 is a plot of the ratio of the measured outdoor air intake to the design intake versus outdoor air temperature, with a distinction between systems with economizer cycles and those without. The mean ratio of the measured to design outdoor airflow is 1.93, including one case where the measured value is about 30 times larger than the design minimum. The mean is 2.28 for the economizer systems and 1.37 for noneconomizer systems. Economizer systems are expected to have a higher ratio of measured to design, since they increase the outdoor air intake for free cooling and the design value is a minimum. Note the existence of many points with a ratio of measured to design below 1.0, which would not exist if the systems were operating as intended.

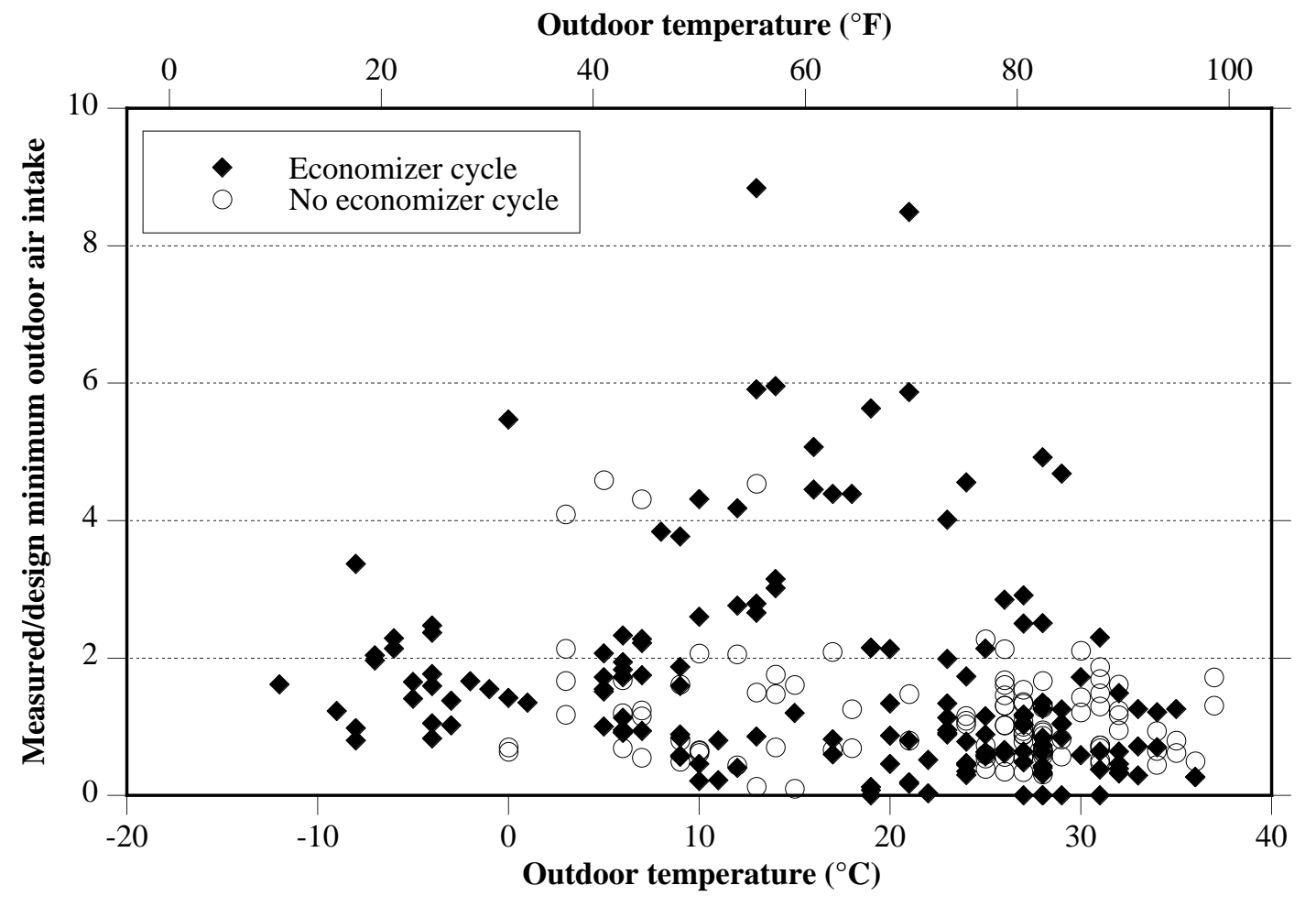

Figure 13 Ratio of measured to design outdoor airflow versus outdoor temperature

As described in section 2.2, outdoor air ventilation rates in the study spaces were calculated based on the measurements for the individual air handlers and the percentage of air from each handler provided to the study space. Table 15 summarizes the measured outdoor air ventilation to the study spaces. The second column presents these values on a per person basis using the actual number of occupants during each measurement. The mean value is $49 \mathrm{L/s}(\mathbf{1 0 5} \mathbf{~ c f m})$ per person, which is high relative to the $10 \mathrm{~L} / \mathrm{s}(20 \mathrm{cfm})$ per person value specified in many current building codes (based on ASHRAE Standard 62-2001). The mean uncertainty in the per person rates is about $40 \%$ of the mean value. Of these per person values, $17 \%$ are below $10 \mathrm{~L} / \mathrm{s}(20$ $\mathrm{cfm})$ per person and $9 \%$ are below $5 \mathrm{~L} / \mathrm{s}(10 \mathrm{cfm})$. Per person rates below $10 \mathrm{~L} / \mathrm{s}(20 \mathrm{cfm})$ were seen in 22 of the 97 mechanically ventilated buildings, while rates below $5 \mathrm{~L} / \mathrm{s}$ (10 cfm) were seen in 13 of the buildings. The table also presents the outdoor air ventilation in $\mathrm{L} / \mathrm{s} \bullet \mathrm{m}^{2}\left(\mathrm{cfm} / \mathrm{ft}^{2}\right)$ 
of floor area and air changes per hour. There are two less cases of ventilation per person because of two events without measured values of occupancy.

\begin{tabular}{|l|c|c|c|}
\hline & $\begin{array}{c}\text { Per person } \\
\mathrm{L} / \mathrm{s}(\mathrm{cfm}) \text { per person }\end{array}$ & $\begin{array}{c}\text { Per unit floor area } \\
\mathrm{L} / \mathrm{s}^{\bullet} \mathrm{m}^{2}\left(\mathrm{cfm} / \mathrm{ft}^{2}\right)\end{array}$ & $\begin{array}{c}\text { Air changes per } \\
\text { hour, } \mathrm{h}^{-1}\end{array}$ \\
\hline \# of values & 367 & 369 & 369 \\
\hline Mean & $\mathbf{4 9}(\mathbf{1 0 5})$ & $\mathbf{1 . 8 7}(\mathbf{0 . 3 7})$ & $\mathbf{1 . 8 3}$ \\
\hline Std. Dev. & $\mathbf{5 4 ( 1 1 4 )}$ & $\mathbf{2 . 0 8}(\mathbf{0 . 4 1})$ & $\mathbf{2 . 0 7}$ \\
\hline Minimum & $0(0)$ & $0(0)$ & 0.00 \\
\hline $10^{\text {th }}$ percentile & $6(13)$ & $0.24(0.05)$ & 0.22 \\
\hline $25^{\text {th }}$ percentile & $13(27)$ & $0.50(0.10)$ & 0.47 \\
\hline Median & $30(63)$ & $1.03(0.20)$ & 0.98 \\
\hline $75^{\text {th }}$ percentile & $\mathbf{6 6}(\mathbf{1 4 0})$ & $\mathbf{2 . 3 0}(\mathbf{0 . 4 5})$ & $\mathbf{2 . 4 6}$ \\
\hline $90^{\text {th }}$ percentile & $\mathbf{1 1 6}(\mathbf{2 4 5})$ & $\mathbf{4 . 6 4}(\mathbf{0 . 9 1})$ & $\mathbf{4 . 4 6}$ \\
\hline Maximum & $\mathbf{3 1 0}(\mathbf{6 5 7})$ & $\mathbf{1 2 . 3 1 ( 2 . 4 2 )}$ & $\mathbf{1 3 . 2 3}$ \\
\hline
\end{tabular}

Table 15 Summary of Measured Outdoor Air Ventilation - Volumetric

Given the noted prevalence of minimum outdoor air intake conditions at higher outdoor air temperatures, the per person ventilation values were separated into those with outdoor temperatures below and above $20{ }^{\circ} \mathrm{C}\left(68^{\circ} \mathrm{F}\right)$. The mean value below $20^{\circ} \mathrm{C}\left(68^{\circ} \mathrm{F}\right)$ is $60 \mathrm{~L} / \mathbf{s}$ $(126 \mathbf{~ c f m})$ per person, and the mean for temperatures greater than or equal to that value is $38 \mathrm{~L} / \mathrm{s}$ $(81 \mathrm{cfm})$ per person.

The per person outdoor air rates were also analyzed to identify those for which the outdoor air fraction was below $20 \%$, presuming that those values correspond to operation under minimum outdoor air intake. Of the 367 values of outdoor air per person, 148 correspond to less than $20 \%$ outdoor air. (These minimum conditions are seen in 42 of the 97 mechanically ventilated buildings.) The mean of these values is $13.7 \mathrm{~L} / \mathrm{s}(28.9 \mathrm{cfm})$ per person based on the measured number of occupants, and the median is $11.7 \mathrm{~L} / \mathrm{s}(24.7 \mathrm{cfm})$. Normalizing these minimum outdoor airflows by the number of workstations, rather than the measured number of occupants, yields a mean of $10.5 \mathrm{~L} / \mathrm{s}(22.2 \mathrm{cfm})$ per person and a median of $9.4 \mathrm{~L} / \mathrm{s}(20.0 \mathrm{cfm})$. Of these 148 values corresponding to minimum outdoor air, $41 \%$ are below the per person requirement in Standard 62-2001 based on the measured number of occupants and $50 \%$ are below that requirement based on the number of workstations. In other words, under minimum outdoor air intake, about one-half of the measured outdoor air intake rates are below the requirements in ASHRAE Standard 62-2001 based on the expected occupancy levels in the space. Similarly, about $20 \%$ of these minimum values are below $5 \mathrm{~L} / \mathrm{s}(10 \mathrm{cfm})$ per measured occupant and about $25 \%$ are below $5 \mathrm{~L} / \mathrm{s}(10 \mathrm{cfm})$ per workstation.

Outdoor air ventilation was also determined from the $\mathrm{CO}_{2}$-based outdoor air fraction multiplied by the measured supply airflow. The values for the air handlers are then combined to determine the outdoor airflow per person for the study spaces, and the results are summarized in Table 16. Due to the large uncertainties in the $\mathrm{CO}_{2}$ outdoor air fraction, the mean uncertainty in the study space outdoor airflow is also quite large, $85 \mathrm{~L} / \mathrm{s}(179 \mathrm{cfm})$ per person. Nevertheless, the mean values of the volumetric and $\mathrm{CO}_{2}$-ratio outdoor ventilation airflow per person are remarkably similar, $49 \mathrm{~L} / \mathbf{s}(105 \mathrm{cfm})$ and $44 \mathrm{~L} / \mathbf{s}(94 \mathrm{cfm})$ respectively. Figure 14 is a plot of the $\mathrm{CO}_{2}$-ratio ventilation to the volumetric values. While there is significant scatter about the line of perfect agreement, and a tendency for the $\mathrm{CO}_{2}$-ratio values to be lower at the highest per person 
ventilation, the two determinations are consistent on average. A linear regression of $\mathrm{CO}_{2}$-ratio to the volumetric ventilation yields a slope of $\mathbf{0 . 8 0}$ and an r-squared of $\mathbf{0 . 6 4}$.

\begin{tabular}{|l|c|}
\hline & $\begin{array}{c}\text { Outdoor air per person, } \\
\mathrm{L} / \mathrm{s}(\mathrm{cfm})\end{array}$ \\
\hline \# of values & 356 \\
\hline Mean & $\mathbf{4 4}(\mathbf{9 4})$ \\
\hline Std. Dev. & $\mathbf{4 7}(\mathbf{1 0 1})$ \\
\hline Minimum & $0(0)$ \\
\hline $10^{\text {th }}$ percentile & $5(11)$ \\
\hline $25^{\text {th }}$ percentile & $12(26)$ \\
\hline Median & $31(65)$ \\
\hline $75^{\text {th }}$ percentile & $\mathbf{5 9 ( 1 2 5 )}$ \\
\hline $90^{\text {th }}$ percentile & $\mathbf{9 6}(\mathbf{2 0 3})$ \\
\hline Maximum & $\mathbf{3 3 9}(\mathbf{7 1 7})$ \\
\hline
\end{tabular}

Table 16 Summary of Measured Outdoor Air Ventilation - $\mathrm{CO}_{2}$ Ratio

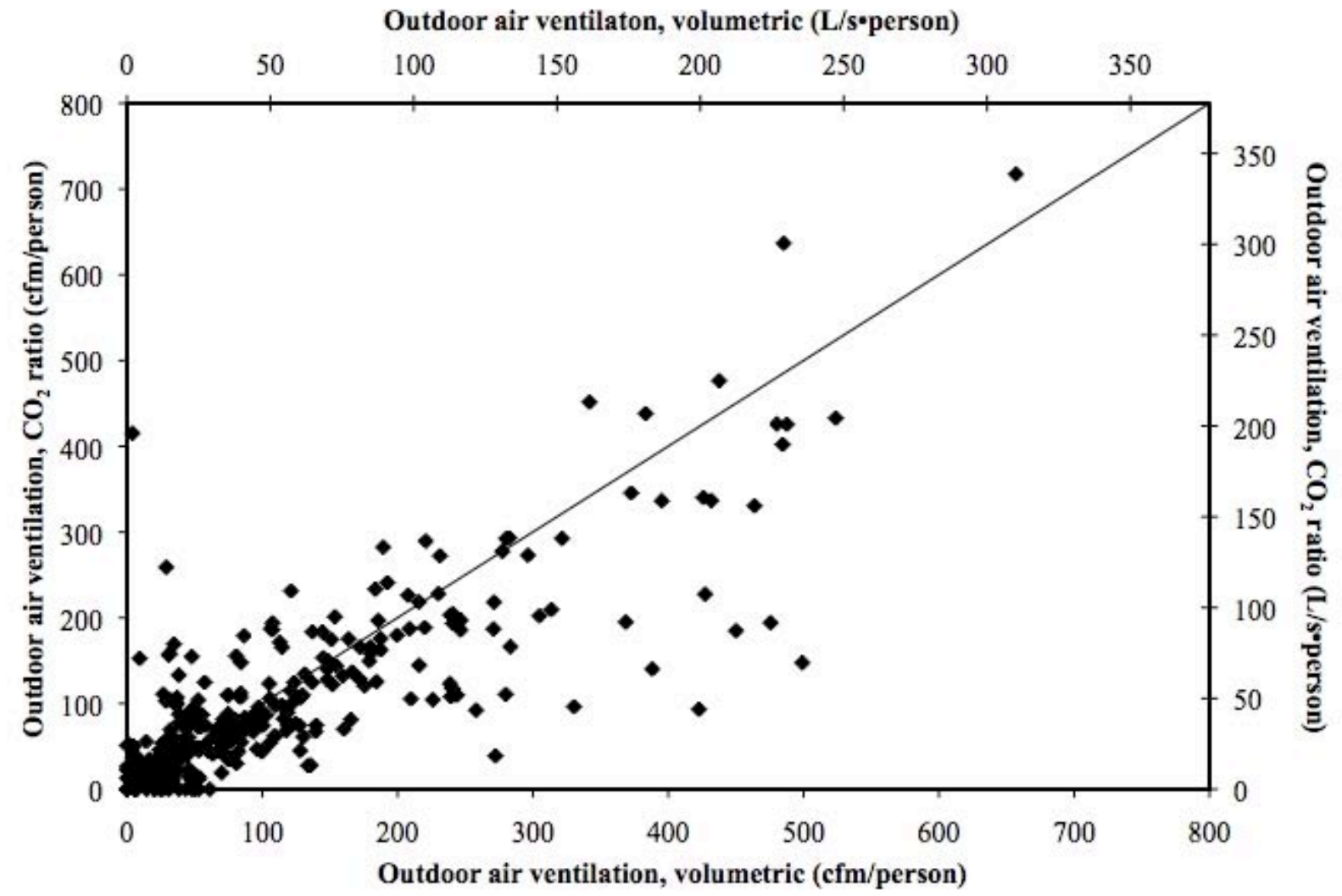

Figure 14 Outdoor air ventilation, $\mathrm{CO}_{2}$-ratio versus volumetric

As noted, the measured per person outdoor air ventilation values are high relative to the outdoor air requirement in ASHRAE Standard 62-2001. These values are higher than might be expected for two primary reasons; the occupant density is below design and the outdoor air fraction is frequently not at minimum, generally due to economizer operation. As noted earlier, the mean measured occupant density is about 3.5 persons per $100 \mathrm{~m}^{2}\left(3.2\right.$ per $\left.1000 \mathrm{ft}^{2}\right)$, corresponding to about $80 \%$ of the number of workstations and about half of the default occupant density in Standard 62-2001. In addition, the mean outdoor air fraction is about 0.40. If each outdoor air 
measurement is adjusted to the design occupant density (number of workstations) and to minimum outdoor air intake, then the per person ventilation values are more consistent with expectations. Table 17 presents these adjustments, with the measured outdoor air ventilation per person from Table 15 in the second column. The next column presents the outdoor air ventilation normalized by the number of workstations in the space rather than the measured occupancy, which reduces the mean ventilation rate to $36 \mathrm{~L} / \mathbf{s}(\mathbf{7 6} \mathbf{~ c f m})$ per person. In the last two columns, the values are adjusted to an outdoor air fraction of 0.15 . This adjustment involves dividing the outdoor air ventilation rate by the actual outdoor air fraction and then multiplying the result by 0.15 , unless the actual fraction is already 0.15 or less. In the latter cases, the ventilation rate is not adjusted. The $15 \%$ value is used as a typical value of the minimum outdoor air fraction. (Note from Table 6 that the mean value of the design minimum outdoor air fraction was $\mathbf{1 9} \%$, and the median was $12 \%$.) The values in the fourth column are based on the number of workstations in the study space, while the values in the last column use the default occupant density for office space in Standard 62-2001, i.e., 7 people per $100 \mathrm{~m}^{2}\left(1000 \mathrm{ft}^{2}\right)$. As discussed earlier, the design value for occupant density is not available for the study spaces. However, if one uses the default value in Standard 62-2001 for office space, as in the last column of Table 17 , the mean per person ventilation rate are very close to the requirement in the standard.

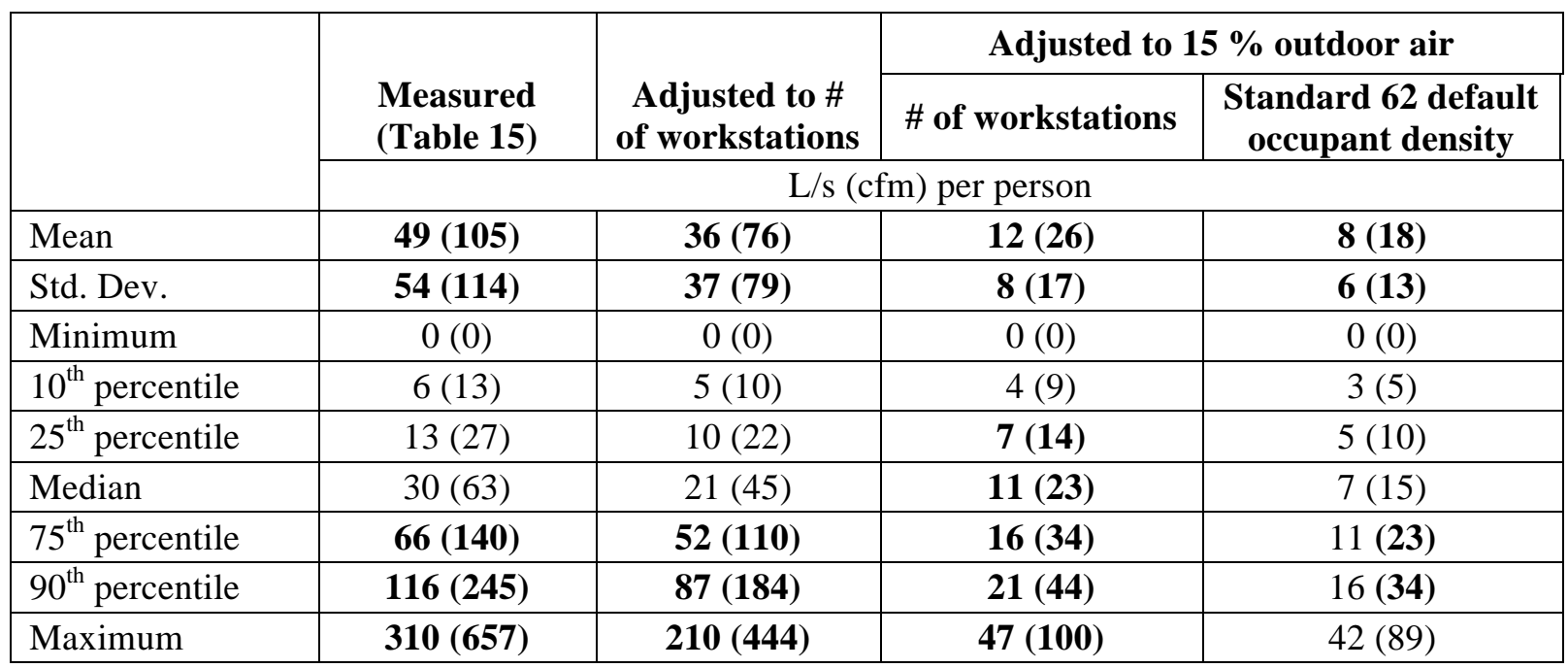

Table 17 Outdoor air ventilation adjusted for occupancy and outdoor air fraction

\subsubsection{Outdoor Airflows from Peak Carbon Dioxide}

Indoor carbon dioxide concentrations were also used to estimate outdoor air ventilation, using a steady-state, single-zone mass balance analysis to relate the indoor $\mathrm{CO}_{2}$ concentration to the per person outdoor air ventilation as discussed in Section 2.2. As noted, a critical assumption behind the approach is that the indoor $\mathrm{CO}_{2}$ concentration is indeed at steady state. It is also assumes constant outdoor concentration, ventilation and occupancy, as well as a uniform indoor $\mathrm{CO}_{2}$ concentration. Note that this approach provides the only means to estimate the outdoor air ventilation in the three naturally ventilated buildings.

As described earlier, peak $\mathrm{CO}_{2}$ concentrations were used to estimate outdoor ventilation per person for all 100 study spaces. These estimates are based on averaging the $\mathrm{CO}_{2}$ concentrations among the fixed monitors in each space on a 10 min basis, and then identifying the maximum value of this average for the morning and afternoon of each day. The per person ventilation rates based on these estimates are summarized in Table 18. The second column contains all the values of the per person outdoor airflow determined from the peak $\mathrm{CO}_{2}$ data. The third column contains 
only those values obtained on the "test days," i.e., those days (typically Wednesday and Thursday of the study week) during which the other ventilation measurements were made. The last column reproduces the summary statistics for the volumetric measurements from Table 15. The mean uncertainty in the peak $\mathrm{CO}_{2}$ ventilation rates is $10 \mathrm{~L} / \mathbf{s}(22 \mathbf{~ c f m})$ per person, which is about one-half the mean uncertainty for the volumetric rates. Also, note that the peak $\mathrm{CO}_{2}$ values are significantly lower than those obtained from the volumetric measurements. This trend is contrary to what one might expect, as the outdoor airflows determined using the peak $\mathrm{CO}_{2}$ method include both ventilation system outdoor air intake and outdoor air infiltration due to envelope leakage, while the volumetric results include only the former. Figure 15 is a plot of the per person outdoor air ventilation determined from the peak $\mathrm{CO}_{2}$ concentrations versus the corresponding volumetric values. The solid line corresponds to perfect agreement. Note that above roughly $25 \mathrm{~L} / \mathrm{s}(50 \mathrm{cfm})$ per person, almost all of the $\mathrm{CO}_{2}$-based values are lower than the volumetric airflows.

\begin{tabular}{|c|c|c|c|}
\hline & \multicolumn{3}{|c|}{ Outdoor air ventilation, $\mathrm{L} / \mathrm{s}(\mathrm{cfm})$ per person } \\
\hline & All peak $\mathrm{CO}_{2}$ data & $\begin{array}{c}\text { Peak } \mathrm{CO}_{2} \text { data on } \\
\text { "test days" }\end{array}$ & $\begin{array}{l}\text { Volumetric results } \\
\text { from Table } 15\end{array}$ \\
\hline \# of values & 548 & 353 & 367 \\
\hline Mean & $20(43)$ & $21(45)$ & $49(105)$ \\
\hline Std. Dev. & $14(31)$ & $17(35)$ & $54(114)$ \\
\hline Minimum & $6(13)$ & $6(13)$ & $0(0)$ \\
\hline $10^{\text {th }}$ percentile & $10(20)$ & $10(21)$ & $6(13)$ \\
\hline $25^{\text {th }}$ percentile & $12(26)$ & $13(27)$ & $13(27)$ \\
\hline Median & $18(37)$ & $18(38)$ & $30(63)$ \\
\hline $75^{\text {th }}$ percentile & $24(50)$ & $25(53)$ & $66(140)$ \\
\hline $90^{\text {th }}$ percentile & $32(68)$ & $33(71)$ & $116(245)$ \\
\hline Maximum & $213(452)$ & $213(452)$ & $310(657)$ \\
\hline
\end{tabular}

Table 18 Summary of Measured Outdoor Air Ventilation - Peak $\mathrm{CO}_{2}$

The reason that the peak $\mathrm{CO}_{2}$ values tend to be lower than expected has been investigated, but no explanation has yet been verified. Considering the methodology behind the peak $\mathrm{CO}_{2}$ analysis, one might suspect the lack of steady-state $\mathrm{CO}_{2}$ concentrations could be impacting the agreement between the two values. However, steady state is more likely to occur at the higher ventilation rates due to the shorter system time constants, resulting in better agreement at higher rates, which is contrary to what is seen in Figure 15. Another potential explanation is the existence of significant $\mathrm{CO}_{2}$ concentration gradients within the study spaces, as well as between them and adjoining spaces, given that the single-zone analysis method assumes a uniform concentration within the zone and neglects interzone transfer of $\mathrm{CO}_{2}$. While it is certainly possible that the $\mathrm{CO}_{2}$ concentrations were different in adjoining zones, one would expect the impact to be positive in some cases and negative in others. However, the differences in the data tend to all be in one direction. The level of agreement was examined in those study spaces that corresponded to an entire building, for which concentration differences in adjoining spaces are not an issue, and the peak $\mathrm{CO}_{2}$ and volumetric ventilation rates were not observed to agree any better. Note that the fixed $\mathrm{CO}_{2}$ monitors in the study spaces were placed at a height of $1.1 \mathrm{~m}$ (43 in.) above the floor and at locations representative of workstation layout and work activities, i.e., locations in hallways and passageways were intentionally avoided (EPA 2003). Given these guidelines on location, it is possible that the measured $\mathrm{CO}_{2}$ concentrations are higher than the study-space 
average. If the measured $\mathrm{CO}_{2}$ concentration is indeed higher than the true space average, then the calculated ventilation rates would be low relative to their actual value. Also, it is reasonable to expect that the lack of uniformity would be more pronounced at higher outdoor air ventilation with less recirculation of return air, leading to the observed increase in errors. However, it is not possible to verify the magnitude of the concentration nonuniformity in these spaces based on the available data, and therefore it cannot be confirmed whether this is necessarily a valid explanation for the observed differences. The peak $\mathrm{CO}_{2}$ concentrations were examined with the issue of nonuniformity in mind, and it was determined that the actual average concentration in the study space would have to be $360 \mathrm{mg} / \mathrm{m}^{3}$ to $720 \mathrm{mg} / \mathrm{m}^{3}$ (200 ppm(v) to $400 \mathrm{ppm}(\mathrm{v})$ ) lower than that measured by the fixed monitors to explain the observed differences.

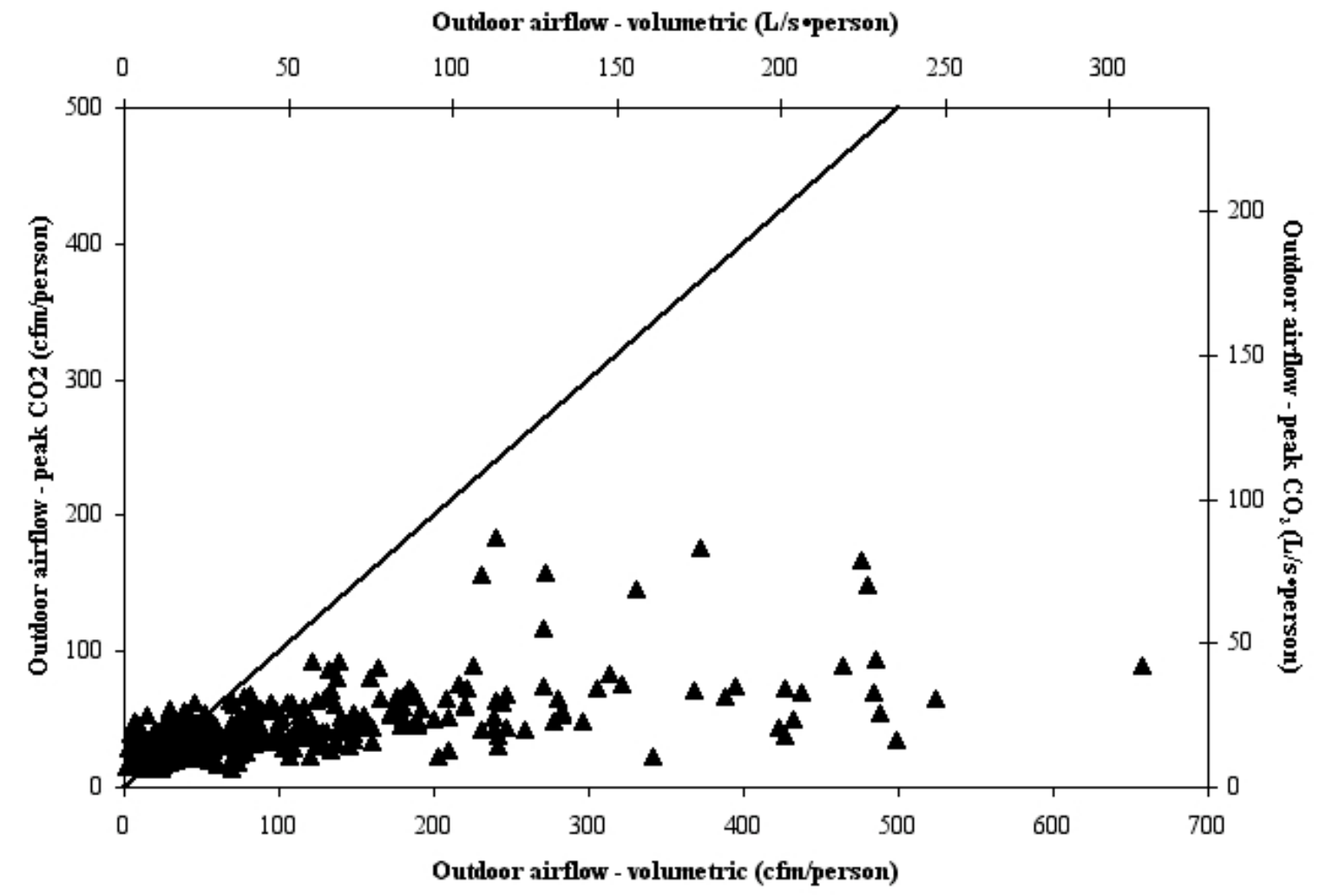

Figure 15 Outdoor air ventilation, $\mathrm{CO}_{2}$ peak versus volumetric

The peak $\mathrm{CO}_{2}$ analysis provides the only means for estimating ventilation rates in the three naturally ventilated buildings. Table 19 presents the estimated outdoor air ventilation rates for each of the three study spaces for each time period it was estimated, generally once in the morning and once in the afternoon. These values are presented first as per person values, based only on the difference between the peak $\mathrm{CO}_{2}$ concentration and the outdoor concentration, along with an estimate of the uncertainty in each value. The last column presents these values in air changes per hour, based on the study space volume and the measured occupancy. The first study space, NYBS06, has high per person ventilation rates, especially in units of air changes per hour, but also high uncertainties. Since high ventilation values correspond to low differences between the peak $\mathrm{CO}_{2}$ concentration and the outdoor concentration, higher uncertainties always exist at higher ventilation rates. It is not clear why the ventilation rates in this building are so high, but it does have operable windows, $50 \%$ of which were reported to be open during the measurements. In addition, the building has toilet exhausts with design flow rates per floor area on the high end of the buildings. However, the measured exhaust flows during the test week were zero. The 
afternoon reading on the third day for NYBS06 has a much lower ventilation rate than the other times. There were no outdoor concentration readings available for building ORIS02, and a value of $670 \mathrm{mg} / \mathrm{m}^{3}$ (373 ppm(v)) was assumed. While peak $\mathrm{CO}_{2}$ analysis allows the estimation of ventilation in the naturally ventilated buildings, the comparison with the volumetric values in the mechanically ventilated buildings does raise questions regarding their validity.

\begin{tabular}{|l|c|c|c|c|c|c|}
\hline $\begin{array}{l}\text { Study } \\
\text { space }\end{array}$ & Date & Time of day & $\begin{array}{c}\text { Outdoor air } \\
\text { ventilation } \\
\text { per person }\end{array}$ & $\begin{array}{c}\text { Uncertainty } \\
\text { in outdoor air } \\
\text { per person }\end{array}$ & $\begin{array}{c}\text { Outdoor air } \\
\text { ventilation }\end{array}$ & $\begin{array}{c}\text { Uncertainty in } \\
\text { outdoor air } \\
\text { ventilation }\end{array}$ \\
\hline & & AM or PM & \multicolumn{2}{|c|}{ L/s (cfm) } & \multicolumn{2}{|c|}{$\mathrm{h}^{-1}$} \\
\hline NYBS06 & $6 / 16 / 98$ & AM & $40.3(85.4)$ & $17.8(38.0)$ & 33.4 & 16.3 \\
\hline & $6 / 16 / 98$ & PM & $27.8(58.9)$ & $8.8(18.6)$ & 28.5 & 12.4 \\
\hline & $6 / 17 / 98$ & AM & $42.6(90.2)$ & $20.0(42.3)$ & 40.2 & 20.9 \\
\hline & $6 / 17 / 98$ & PM & $33.3(70.6)$ & $12.4(26.3)$ & 40.3 & 18.1 \\
\hline & $6 / 18 / 98$ & AM & $44.2(93.6)$ & $21.5(45.5)$ & 46.1 & 22.9 \\
\hline & $6 / 18 / 98$ & PM & $19.6(41.5)$ & $4.6(9.7)$ & 7.8 & 4.5 \\
\hline ORIS02 & $8 / 30 / 94$ & AM & $26.1(55.4)$ & $8.0(17.0)$ & 0.5 & 0.2 \\
\hline & $8 / 30 / 94$ & PM & $25.9(54.9)$ & $7.9(16.7)$ & 0.4 & 0.2 \\
\hline & $8 / 31 / 94$ & AM & $29.5(62.5)$ & $10.1(21.4)$ & 0.5 & 0.2 \\
\hline & $8 / 31 / 94$ & PM & $28.0(59.3)$ & $9.2(19.4)$ & 0.6 & 0.3 \\
\hline & $9 / 1 / 94$ & AM & $45.2(95.7)$ & $23.1(49.0)$ & 1.0 & 0.5 \\
\hline & $9 / 1 / 94$ & PM & $28.3(60.0)$ & $9.4(19.8)$ & 0.5 & 0.2 \\
\hline WAIW01 & $2 / 25 / 97$ & AM & $8.4(17.9)$ & $1.2(2.5)$ & 0.5 & 0.1 \\
\hline & $2 / 25 / 97$ & PM & $7.4(15.7)$ & $1.0(2.0)$ & 0.4 & 0.1 \\
\hline & $2 / 26 / 97$ & AM & $12.6(26.8)$ & $2.2(4.6)$ & 0.4 & 0.1 \\
\hline & $2 / 26 / 97$ & PM & $7.4(15.6)$ & $1.0(2.0)$ & 0.4 & 0.1 \\
\hline & $2 / 27 / 97$ & AM & $8.8(18.7)$ & $1.2(2.6)$ & 0.5 & 0.1 \\
\hline
\end{tabular}

Table 19 Outdoor air ventilation for naturally ventilated spaces 


\subsubsection{Supply Diffuser Airflows}

The BASE protocol calls for airflow to be measured at the individual supply diffusers serving the study space one time during the test week. Diffuser measurements were made in 88 of the 97 mechanically ventilated buildings, and Table 20 presents the results of those measurements. The second column contains the number of diffusers in these 88 study spaces, while the third column summarizes the fraction of those diffusers for which the supply airflow was measured. The total supply airflow, normalized by study space floor area, is presented in the fourth column. This value is adjusted to account for less than $100 \%$ of the diffusers being measured by assuming the supply airflow per diffuser at the unmeasured diffusers is the same as at the mean of the measured value. The last column is the total (adjusted) supply airflow in the fourth column divided by the supply airflow determined at the air handlers, as discussed in section 3.3.1. On average, the total supply airflow at the diffusers is only $73 \%$ of the value measured at the air handlers. This lack of agreement is a function of the large measurement uncertainties in both values, plus the possibility of supply duct leakage. However, the existence and magnitude of such leakage was not assessed as part of this study, and these data do not serve as a reliable measure of duct leakage.

\begin{tabular}{|l|c|c|c|c|}
\hline & $\begin{array}{c}\text { \# of } \\
\text { diffusers }\end{array}$ & $\begin{array}{c}\text { Fraction of } \\
\text { diffusers } \\
\text { measured }\end{array}$ & $\begin{array}{c}\text { Total diffuser } \\
\text { flow, adjusted } \\
\mathrm{L} / \mathrm{s}^{2} \mathrm{~m}^{2}\left(\mathrm{cfm} / \mathrm{ft}^{2}\right)\end{array}$ & $\begin{array}{c}\text { Total diffuser flow/ } \\
\text { Study space supply } \\
\text { airflow at air handlers }\end{array}$ \\
\hline Mean & 93 & 0.94 & $3.40(0.67)$ & 0.73 \\
\hline Std. Dev. & 42 & 0.09 & $1.66(0.33)$ & 0.36 \\
\hline Minimum & 13 & 0.57 & $0.30(0.06)$ & 0.16 \\
\hline $10^{\text {th }}$ percentile & 39 & 0.86 & $1.31(0.26)$ & 0.36 \\
\hline $25^{\text {th }}$ percentile & 71 & 0.91 & $2.28(0.45)$ & 0.48 \\
\hline Median & 93 & 0.97 & $3.27(0.64)$ & 0.67 \\
\hline $75^{\text {th }}$ percentile & 107 & 1.00 & $4.23(0.83)$ & 0.83 \\
\hline $90^{\text {th }}$ percentile & 146 & 1.00 & $5.25(1.03)$ & 1.22 \\
\hline Maximum & 258 & 1.00 & $9.66(1.90)$ & 1.96 \\
\hline
\end{tabular}

Table 20 Summary of measured supply airflows at diffusers

\subsubsection{Exhaust Airflows}

Airflows for the exhaust fans serving each study space were measured one time during the test week. Measured airflows were obtained for 56 of the 159 exhaust fans serving the study spaces. Of these values, design airflows are only available for 41 of the fans. Neglecting the seven cases where the measured exhaust airflow is zero, the average ratio of the measured exhaust airflow to the design value is 0.57 . The median value is 0.47 and the standard deviation is 0.34 ; the 10 and 90 percentile values are 0.21 and 0.99 respectively. 


\section{DISCUSSION}

\subsection{Summary of Results}

The ventilation-related information collected as part of the BASE study provides a unique characterization of ventilation system design and performance in U.S. office buildings. No such database of randomly selected office buildings existed prior to this effort, making the results of the survey that much more significant. While the office buildings studied tend to be larger and with higher occupancy than the average U.S. office building, the results obtained are quite revealing. In terms of design, the data show the relative prevalence of different system types and different approaches to outdoor air control, as described in Tables 4 and 5. Of the 141 ventilation systems considered, 50 are constant volume and the rest are VAV. In almost $75 \%$ of the study spaces the systems employ economizer control to provide "free cooling" when the outdoor weather is appropriate. Twenty-one of the spaces have dedicated outdoor air fans, and five have $100 \%$ outdoor air systems.

As expected based on thermal load considerations, but never previously verified, the average value of the supply air capacity is about $5 \mathrm{~L} / \mathrm{s} \bullet \mathrm{m}^{2}\left(1 \mathrm{cfm} / \mathrm{ft}^{2}\right)$. Other system design parameters of interest have the following mean values: ratio of supply airflow capacity to return airflow capacity, 1.14; design minimum outdoor air per person (workstation), $18 \mathrm{~L} / \mathrm{s}$ (39 cfm); and, ratio of design minimum outdoor air intake to supply air capacity, $\mathbf{1 9} \%$. The per person design minimum outdoor air intake, based on the number of workstations, is significantly higher than the requirement in ASHRAE Standard 62-2001 of $10 \mathrm{~L} / \mathrm{s}(20 \mathrm{cfm})$ per person. However, if the per person design value is instead calculated using the default occupant density in the ASHRAE standard, the mean value of the minimum outdoor air intake per person is $13 \mathrm{~L} / \mathrm{s}(26 \mathrm{cfm})$ and the median is roughly $9 \mathrm{~L} / \mathrm{s}(17 \mathrm{cfm})$. However, as noted, the design occupancy used to determine the design minimum outdoor air intake is not available for the systems studied.

The BASE study also provides valuable information on occupant density in office buildings. The mean number of workstations per $100 \mathrm{~m}^{2}\left(1000 \mathrm{ft}^{2}\right)$ is about 5, as compared with the default value in Standard 62-2001 of 7. However, the recent revision of that standard via addendum $n$ (ASHRAE 2003) reduces the default value to 5, which appears to be a reasonable change given the results of this study. The measured occupant density in the spaces is lower still, with a mean value of 4.0 people $/ 100 \mathrm{~m}^{2}$ (3.7 people $/ 1000 \mathrm{ft}^{2}$ ), corresponding to about $80 \%$ of the workstations being occupied.

The ventilation measurements indicate how the systems operate relative to their design and also provide performance parameters that can be used to analyze other data collected in the BASE study, for example contaminant concentrations and prevalence of occupant symptoms. The mean measured supply airflow for the 97 mechanically ventilated study spaces is very close to the mean design value, i.e., $5 \mathrm{~L} / \mathrm{s}^{\circ} \mathrm{m}^{2}\left(1 \mathrm{cfm} / \mathrm{ft}^{2}\right)$. As might be expected, these supply values are relatively independent of outdoor air temperature for the constant volume systems but tend to increase for warmer temperatures in the VAV systems. The measured outdoor air fraction, i.e., the ratio of the outdoor air intake to the supply airflow, has a mean value of about 0.40 . For buildings with economizer controls, the outdoor air fraction tends to be lowest for warmer temperatures and increases at milder temperatures. However, with only 4 measurements per system, generally under similar weather conditions, the noted dependence mixes the results for many buildings, and the temperature dependence cannot be examined in detail for any single building. Outdoor air ventilation rates tend to be higher than might be expected, with a mean value of $49 \mathrm{~L} / \mathrm{s}(105 \mathrm{cfm})$ per person based on the number of occupants and $36 \mathrm{~L} / \mathrm{s}(76 \mathrm{cfm})$ per person based on the number of workstations in the space. Still, seventeen percent of these 
measured values (per occupant) are below the $10 \mathrm{~L} / \mathrm{s}(20 \mathrm{cfm})$ per person requirement in ASHRAE Standard 62-2001, and these lower rates occur in 22 of the 97 mechanically ventilated buildings. While these values are high on average relative to the minimum outdoor air requirements in Standard 62, the high outdoor air fractions and the low occupancy relative to the actual number of workstations (and to the default occupancy value in the standard) explains most of the higher values. Adjusting the measured outdoor air ventilation rates to minimum outdoor air conditions and to the occupant density in Standard 62 reduces the mean to $9 \mathrm{~L} / \mathrm{s}(19 \mathrm{cfm})$ per person. Considering only those values that correspond to minimum outdoor air intake, the mean ventilation rate is $14 \mathrm{~L} / \mathrm{s}(29 \mathrm{cfm})$ per person. Adjusting these minimum values for the number of workstations rather than the measured occupancy levels yields a mean of $11 \mathrm{~L} / \mathrm{s}(22 \mathrm{cfm})$ per person, with one-half of these minimum values being below the requirement in ASHRAE Standard 62-2001. In other words, under minimum outdoor air intake, about one-half of the measured outdoor air intake rates are below the requirements in ASHRAE Standard 62-2001 based on the expected occupant levels in the space, and about one-quarter of the rates are below $5 \mathrm{~L} / \mathrm{s}(10 \mathrm{cfm})$ per person, i.e., one-half of the ASHRAE requirement.

The outdoor air ventilation rates calculated from the $\mathrm{CO}_{2}$-based outdoor air fraction (determined from airstream $\mathrm{CO}_{2}$ concentrations) multiplied by the volumetric supply airflow rate are generally consistent with the outdoor air rates from volumetric airflow measurements in the air handlers. However, the $\mathrm{CO}_{2}$ ratio ventilation rates have much larger uncertainties due to the larger uncertainties in the $\mathrm{CO}_{2}$-based outdoor air fractions. Outdoor air ventilation rates determined from steady-state analysis of peak $\mathrm{CO}_{2}$ concentrations in the space are consistently lower than the volumetric outdoor air rates. A number of explanations have been explored, but the reason for this discrepancy has not been identified. Therefore, questions exist as to the reliability of the peak- $\mathrm{CO}_{2}$ ventilation rates.

\subsection{Comparison with European Audit Project}

During the time of the BASE study, a similar research effort was conducted in Europe. The European Audit Project involved measurements of building characteristics, environmental conditions and ventilation performance, as well as the administration of occupant questionnaires, in 56 buildings in eleven European countries (Bluyssen et al. 1995 and 1996). Ventilation performance was measured in nine of the countries using a range of different techniques, e.g., tracer gas decay in a single room, constant concentration tracer gas, and subtraction of exhaust from supply airflows determined using velocity traverses. The final report (Bluyssen et al., 1995) contains one value of supply airflow, infiltration and outdoor airflow per unit floor area for each building in which they were measured. The results are also presented in the form of cumulative frequency distributions for outdoor and supply airflow in units of $\mathrm{L} / \mathrm{s}-\mathrm{m}^{2}$ and air changes per hour. The median value of the supply airflow is roughly $2.2 \mathrm{~L} / \mathrm{s}-\mathrm{m}^{2}\left(0.43 \mathrm{cfm} / \mathrm{ft}^{2}\right)$, which is about one-half of the median for the BASE buildings. The median outdoor airflow in the European Audit buildings is about $1.7 \mathrm{~L} / \mathrm{s}-\mathrm{m}^{2}\left(0.33 \mathrm{cfm} / \mathrm{ft}^{2}\right)$, which is somewhat higher than the median for the BASE buildings of $1.1 \mathrm{~L} / \mathrm{s}-\mathrm{m}^{2}\left(0.22 \mathrm{cfm} / \mathrm{ft}^{2}\right)$. In units of air changes per hour, the medians are roughly $2.1 \mathrm{~h}^{-1}$ and $1.0 \mathrm{~h}^{-1}$ for the European and BASE buildings respectively. Given the uniqueness of these two datasets, a more detailed comparison of the ventilation results would be worth pursuing. 


\subsection{Recommendations for Ventilation Assessment}

In addition to analyzing the ventilation-related data collected as part of the BASE study, another objective of this effort was to examine the procedures used to collect these data and recommend changes to the protocol for potential consideration in future studies. In terms of the design information, it would have been helpful to collect sufficient design data to perform an airflow balance on each building and each study space. The existing protocol includes the collection of design specifications for only the supply, return and exhaust fans that serve the study space. These data only allow the calculation of the net design airflow into and out of the building when the study space is a whole building. It would have been desirable to collect design data for all fans serving the building, including supply and return fan capacities, minimum outdoor air values, and exhaust fan capacities. Given the interest in net airflow balances for whole buildings, particularly in the context of infiltration and moisture control, such data would be of great interest.

The determination of the outdoor air fraction from $\mathrm{CO}_{2}$ concentrations in the supply, return and outdoor airstreams was associated with large measurement uncertainties due to the uncertainty in the concentration measurement itself and the low concentration differentials that exist under some conditions. These large uncertainties limited the usefulness of multiplying these outdoor air fractions by system supply airflows as a means of determining outdoor air intake. Nevertheless, this approach still has value based on the relative simplicity of measuring $\mathrm{CO}_{2}$ concentrations and on the fact that some outdoor air intakes are configured such that a velocity traverse is impractical. The $\mathrm{CO}_{2}$ approach to determining outdoor air fraction could be improved by using a more accurate concentration monitor, employing the uncertainty in the differential concentration rather than absolute concentration (when a single monitor is used), and making the concentration measurements after the indoor concentration has increased to the maximum degree expected based on the occupancy schedule. Despite these large uncertainties, the outdoor air fractions determined from $\mathrm{CO}_{2}$ concentrations agree on average with the volumetric outdoor air fractions.

Outdoor air ventilation measurements are performed for a number of reasons, but often to determine the minimum outdoor airflow for a system. Based on the measurements in this study, it is evident that one is more likely to encounter conditions of minimum intake at warmer outdoor air temperatures, perhaps $25^{\circ} \mathrm{C}\left(77^{\circ} \mathrm{F}\right)$ and above. Minimum intake is less likely to be encountered at colder temperatures based on the data presented here. Since the dependence of outdoor air fraction on temperature is building specific, it is important to obtain a sense of this dependency when studying a building if one aims to determine outdoor airflow under conditions of minimum intake.

Outdoor air ventilation was also estimated based on peak $\mathrm{CO}_{2}$ concentrations, using a singlezone steady-state mass balance analysis of each study space. The values determined tended to be lower than those based on volumetric airflow measurements at the air handlers, and the reason for this difference is not evident. In fact, one would expect these values to be higher since they include envelope infiltration in addition to outdoor air intake. One potential explanation is that the concentrations measured in the space were elevated due to the influence of high $\mathrm{CO}_{2}$ levels from occupant exhalations. The $\mathrm{CO}_{2}$ data collected in the BASE study should be examined further to understand this discrepancy and potentially determine ways to improve this approach to estimate building ventilation. In addition, the reliability of the estimates of the generation rates of $\mathrm{CO}_{2}$ from occupants and of the occupant activity or met levels used in making these estimates merits evaluation if this approach is going to be more widely used. Current guidance on estimating ventilation rates based on peak $\mathrm{CO}_{2}$ levels (ASTM 1998) may then need to be updated based on the results of this evaluation. 
In addition to these potential modifications of the BASE protocol, there are other ventilation performance parameters of interest that could be added to such evaluations. One such addition is the determination of envelope airtightness using fan pressurization testing. The importance of building leakage on energy consumption and indoor air quality has been discussed elsewhere and the available airtightness data is quite limited (Persily 1998). In addition, building survey protocols could also be extended to include tracer gas measurements of infiltration rates, both with the ventilation systems on and off. These rates are again of interest due to their influence on energy and indoor air quality, and the number of office buildings in which they have been measured is indeed small.

The challenges in making reliable measurements of outdoor air intake rates is evident from this study. Some of the problems include limited access to system components, ductwork configurations that do not provide appropriate traverse planes, and accuracy limitations inherent in duct traverses. Alternative approaches to determining outdoor air intake at air handlers are being investigated and ideally will be more reliable and convenient for field application. One challenge in this respect is the lack of a primary standard for use in evaluating the accuracy of these various approaches.

Finally, the BASE ventilation assessment has provided a unique dataset for U.S. office buildings, but the study was focused intentionally on larger buildings. As noted in the discussion of the CBECS data, most U.S. office buildings are much smaller than those included in the BASE study. Based on both indoor air quality and energy considerations, there is a need to conduct a similar study in smaller office buildings. In addition to the obvious difference of size, smaller buildings tend to different system types that larger buildings and different approaches to design and operation.

\section{ACKNOWLEDGEMENTS}

This effort was supported by the U.S. Environmental Protection Agency under Interagency Agreement No. DW-13-93936601-0. The authors express their appreciation to Gregory Brunner, Laureen Burton, John Girman, Robert Thompson and Susan Womble at EPA and Steven Emmerich and Jonathan Kruft at NIST for their support and assistance in this work. The many useful comments of Terry Brennan and William Fisk are also acknowledged. 


\section{REFERENCES}

Apte, MG, WJ Fisk and JM Daisey. 2000. Associations Between Indoor $\mathrm{CO}_{2}$ Concentrations and Sick Building Syndrome Symptoms in US Office Buildings: An Analysis of the 1994-1996 BASE Study Data. Indoor Air, 10 (4): 246-257.

ASHRAE. 1999. ANSI/ASHRAE Standard 62-1999, Ventilation for Acceptable Indoor Air Quality. American Society of Heating, Refrigerating and Air-Conditioning Engineers.

ASHRAE. 2001a. ANSI/ASHRAE Standard 62-2001, Ventilation for Acceptable Indoor Air Quality. American Society of Heating, Refrigerating and Air-Conditioning Engineers.

ASHRAE. 2001b. ASHRAE Handbook of Fundamentals. American Society of Heating, Refrigerating, and Air Conditioning Engineers.

ASHRAE. 2003. Addendum n to ASHRAE Standard 62-2001. www.ashrae.org.

ASTM. 1998. D6245-98, Standard Guide for Using Indoor Carbon Dioxide Concentrations to Evaluate Indoor Air Quality and Ventilation. American Society for Testing and Materials.

Bluyssen, PM, EO Fernandes, PO Fanger, L Groes, G Clausen, CA Roulet, CA Bernhard, O Valbjorn. 1995. European Audit Project to Optimize Indoor Air Quality and Energy Consumption in Office Buildings, Final Report. The Commission of the European Communities.

Bluyssen, PM, EO Fernandes, L Groes, G Clausen, PO Fanger, O Valbjorn, CA Bernhard, CA Roulet. 1996. European Indoor Air Quality Audit Project in 56 Office Buildings. Indoor Air 6: 221-238.

Brightman, HS, SE Womble, EL Ronca and JR Girman. 1996. Baseline Information on Indoor Air Quality in Large Buildings (BASE '95). Proceedings of 7th International Conference on Indoor Air Quality and Climate, Nagoya, 3:1033-1038.

DOE. 1998. A Look at Commercial Buildings in 1995: Characteristics, Energy Consumption, and Energy Expenditures. DOE/EIA-0625(95). U.S. Department of Energy, Energy Information Administration.

EHE. 2000. Building Assessment Survey and Evaluation (BASE) Study Database Description and Variable List, Environmental Health \& Engineering, Inc. Report \#11868 to U.S.

Environmental Protection Agency.

EHE. 2001a. The Evaluation of Ventilation Performance Measurements Conducted During the Building Assessment Survey Evaluation Study, Environmental Health \& Engineering, Inc. Report to U.S. Environmental Protection Agency.

EHE. 2001b. Summary and Analysis Report of the BASE Study Building Selection Process, Environmental Health \& Engineering, Inc. Report to U.S. Environmental Protection Agency.

EPA. 2003. A Standardized EPA Protocol for Characterizing Indoor Air Quality in Large Office Buildings. U.S. Environmental Protection Agency.

Erdmann, CA, KC Steiner and MG Apte. 2002. Indoor Carbon Dioxide Concentrations and Sick Building Syndrome Symptoms in the BASE Study Revisited: Analyses of the 100 Building Dataset. 9th International Conference on Indoor Air Quality and Climate, Monterey, 3: 443-448.

Ludwig, JF, BJ Baker and JF McCarthy. 2002. Analysis of Ventilation Rates for the BASE Study: Assessment of Measurement Uncertainty and Comparison with ASHRAE 62-1999. Proceedings of Indoor Air 2002. Volume 5: 388-393. 
Persily, AK. 1989. Ventilation Rates in Office Buildings. Proceedings of IAQ '89 The Human Equation: Health and Comfort, San Diego: 128-136.

Persily, AK and WS Dols. 1991. Field Measurements of Ventilation and Ventilation Effectiveness in an Office/Library Building. Indoor Air 3: 229-246.

Persily, AK, WS Dols and SJ Nabinger. 1992. Environmental Evaluation of the Federal Records Center in Overland Missouri. National Institute of Standards and Technology, NISTIR 4883.

Persily, AK. 1997. Evaluating Building IAQ and Ventilation with Indoor Carbon Dioxide. ASHRAE Transactions 103(2): 193-204.

Persily, A. 1998. Myths About Building Envelopes. ASHRAE Journal 41(3): 39-47.

Womble, SE, JR Girman, EL Ronca, R Axelrad, HS Brightman and JF McCarthy. 1995.

Developing Baseline Information on Buildings and Indoor Air Quality (BASE '94): Part I Study Design, Building Selection, and Building Description. Proceedings of Healthy Buildings '95, Milan, 3: 1305-1310.

Womble, SE, EL Ronca, JR Girman and HS Brightman. 1996. Developing Baseline Information on Buildings and Indoor Air Quality (BASE '95). Proceedings of ASHRAE IAQ 96. Paths to Better Building Environments, Baltimore: 109-117. 


\section{Appendix A: BASE Variables Used in Analysis}

This appendix lists the variables used in the analysis presented in this report. The variable names referenced in the BASE protocol are as listed in the BASE Study Database Description and Variable List (EHE 2000) and from the initial processing of the field data by the EPA contractor.

Building Variables

EVENT: Building identifier

A1YEAR: Year built

A1YEAR2: Year of last building addition

A1AREA: Building occupied floor area

A1AREA2: Building gross floor area

A1BELOW: Building stories below grade

A1ABOVE: Building stories above grade

A1VENTIL: Building has mechanical or natural ventilation?

A1COOLIN: Building has air conditioning system, yes or no?

A1HEATIN: Building has air heating system, yes or no?

$\underline{\text { System Variables }}$

SYSTEM: System number

C1TYPE: Central air handling and distribution system type code, A through $\mathrm{P}$ as described in Appendix B

C1RETFAN: Return fan, yes or no?

C1TS\#PCT: Percent of system capacity serving the study space, by air handler \#.

C5CONPOS: Dedicated outdoor air intake fan, outdoor air conditioned

C5UNPOS: Dedicated outdoor air intake fan, outdoor air unconditioned

C5UNSUC1: Outdoor air drawn into system by supply fan suction through distinct intake duct

C5UNSUC2: Outdoor air drawn directly into air handler by supply fan suction with no duct

C5CONST1: 100\% outdoor air system

C5CONST2: System has temperature-based economizer

C5CONST3: System has fixed minimum outdoor air intake

C5CONST4: System has enthalpy-based economizer

C5CONST5: System controls outdoor air intake based on building pressure

C5MINOU1: Minimum outdoor air intake controlled by fixed damper

C5MINOU2: Minimum outdoor air intake controlled by airflow monitoring

C5MINOU3: Minimum outdoor air intake controlled by fan tracking

C7ARAT1: Design supply air capacity of system

C7ARAT2: Design minimum outdoor air intake for system

C7AAREA: Floor area served by system

C7AOCCU: Number of occupants served by air handler

C7ARETFA: System has a return fan?

C7ARET1: Design return air capacity

C7ARET2: Floor area served by return

Study Space Variables

EVENT: Building identifier

TSDESC: Floors and spaces constituting study space

B1AREA: Study space occupied floor area

B1AREA2: Study space gross floor area 
B1AH\#PCT: Percentage of study space air supply by air handler number \#

B1CEILIN: Study space ceiling height

B1PLENUM: Study space plenum height

B1PRIV: Number of private workstations in study space

B1PART: Number of workstations in study space located in partitioned areas

B1OPEN: Number of workstations in study space located in open office areas

B1DESWS: Floor area per workstation

B1SUPPLY: Number of supply vents in the study space

B1OCC_\#A and B1OCC_\#B: Measured test space occupancy, with \# indicating measurement event (Monday is 1 , Tuesday is $2, \ldots$ ); $\mathrm{A}$ indicates morning measurement and $\mathrm{B}$ indicates afternoon

Supply diffuser measurements

D3ADATE: Date of measurement

D3ARAT\#: Measured supply diffuser airflow, \# indicated which diffuser

\section{Exhaust measurements}

C7BAREA: Floor area served by exhaust fan

C7BRATE: Design exhaust airflow rate

C7BLOCAT; Location of exhaust fan

D2DATE: Date of measurement

D2FLOW: Measured airflow rate of exhaust fan

Weather

DATE: Date of measurement

TIME: Time of measurement

TEMP: Outdoor air temperature

Continuous carbon dioxide measurements using fixed monitors

CO2: Measured carbon dioxide concentration.

DATE: Date of measurement

EVENT: Building identifier

SITEID: Sample site identifier

TIME: Time of measurement

Variables provided with data analysis by EPA contractor

These apply to ventilation system airflow and carbon dioxide concentration measurements.

Several are directly from the BASE variable list, but others (primarily volumetric airflow rates) are derived from BASE variables.

Building/study space number

Date of measurement

Period of measurement, AM or PM

Supply airflow rate, for each date and period

Outdoor airflow rate, for each date and period

Recirculation airflow rate, for each date and period

Supply air carbon dioxide concentration, for each date and period

Outdoor air carbon dioxide concentration, for each date and period

Recirculation air carbon dioxide concentration, for each date and period 


\section{Appendix B: System Design Information}

This appendix presents the following design information for the air handlers serving the study spaces:

System ID

System type from list below:

A Single Duct, Constant Volume, Single Zone

B Single Duct, Constant Volume, Multiple Zone Reheat

C Single Duct, Constant Volume, Multiple Zone Bypass

D Single Duct, Variable Air Volume

E Single Duct, Variable Air Volume, Reheat

F Single Duct, Variable Air Volume, Induction

G Single Duct, Variable Air Volume, Fan Powered, Constant Fan

H Single Duct, Variable Air Volume, Fan Powered, Intermittent Fan

I Single Duct, Variable Air Volume, Dual Conduit

J Dual Duct, Constant Volume

K Dual Duct, Constant Volume, Reheat

L Dual Duct, Variable Air Volume, Single Fan

M Dual Duct, Variable Air Volume, Dual Fan

N Multizone, Constant Volume

O Constant Volume, Blow- Through Bypass

P Texas Multizone, or Three-Deck Multizone

Design supply airflow capacity

Floor area served by system

Design supply airflow capacity per unit floor area

Design minimum outdoor air intake

Design minimum outdoor air intake per unit floor area

Number of occupants served by air handler

Design minimum outdoor air intake per person

Ratio of design minimum outdoor air intake to design supply airflow capacity

Occupant density per unit floor area

Design return airflow capacity

Ratio of design supply airflow capacity to design return airflow

Changes in the table relative to the original 2004 report are highlighted in yellow. 


\begin{tabular}{|c|c|c|c|c|c|c|c|c|c|}
\hline \multirow[b]{2}{*}{ System ID } & \multirow{2}{*}{$\begin{array}{c}\text { System } \\
\text { type }\end{array}$} & \multicolumn{2}{|c|}{$\begin{array}{c}\text { Design supply airflow } \\
\text { capacity }\end{array}$} & \multicolumn{2}{|c|}{$\begin{array}{c}\text { Floor area served } \\
\text { by system }\end{array}$} & \multicolumn{2}{|c|}{$\begin{array}{l}\text { Design supply capacity } \\
\text { per unit floor area }\end{array}$} & \multicolumn{2}{|c|}{$\begin{array}{l}\text { Design minimum } \\
\text { outdoor air intake }\end{array}$} \\
\hline & & $\mathrm{L} / \mathrm{s}$ & $\mathrm{cfm}$ & $\mathrm{m}^{2}$ & $\mathrm{ft}^{2}$ & $\mathrm{~L} / \mathrm{s}-\mathrm{m}^{2}$ & $\mathrm{cfm} / \mathrm{ft}^{2}$ & $\mathrm{~L} / \mathrm{s}$ & $\mathrm{cfm}$ \\
\hline ARFW01(01) & $\mathrm{N}$ & 5195 & 11006 & 890 & 9584 & 5.83 & 1.15 & & \\
\hline ARFW01(02) & $\mathrm{N}$ & 5195 & 11006 & 890 & 9584 & 5.83 & 1.15 & & \\
\hline ARFW02(01) & $\mathrm{E}$ & 10638 & 22538 & 3642 & 39201 & 2.92 & 0.57 & 708 & 1501 \\
\hline ARFW02(02) & $\mathrm{E}$ & 9011 & 19091 & 1529 & 16457 & 5.89 & 1.16 & 590 & 1251 \\
\hline ARFW03(01) & $\mathrm{H}$ & 4865 & 10306 & 729 & 7846 & 6.67 & 1.31 & & \\
\hline ARFW03(02) & $\mathrm{H}$ & 4510 & 9555 & 502 & 5404 & 8.98 & 1.77 & & \\
\hline AZHS02(01) & $\mathrm{E}$ & 7835 & 16600 & 1085 & 11680 & 7.22 & 1.42 & & \\
\hline AZHS02(02) & $\mathrm{E}$ & 7084 & 15009 & 855 & 9206 & 8.28 & 1.63 & & \\
\hline AZHS04(01) & $\mathrm{E}$ & 9540 & 20212 & 1731 & 18630 & 5.51 & 1.08 & & \\
\hline AZHS04(02) & $\mathrm{A}$ & 1606 & 3402 & 189 & 2033 & 8.50 & 1.67 & & \\
\hline AZHW10(01) & $\mathrm{N}$ & 9446 & 20012 & 1227 & 13203 & 7.70 & 1.52 & & \\
\hline AZHW10(02) & $\mathrm{N}$ & 7557 & 16010 & 317 & 3408 & 23.86 & 4.70 & & \\
\hline AZHW11(01) & $\mathrm{N}$ & 19364 & 41024 & 2599 & 27972 & 7.45 & 1.47 & & \\
\hline AZHW12(01) & $\mathrm{G}$ & 7455 & 15795 & 3732 & 40169 & 2.00 & 0.39 & 1077 & 2281 \\
\hline AZHW12(02) & $\mathrm{G}$ & 7462 & 15809 & 3202 & 34462 & 2.33 & 0.46 & 1077 & 2281 \\
\hline CAES17(01) & $\mathrm{K}$ & 11713 & 24814 & 1458 & 15696 & 8.03 & 1.58 & 1757 & 3722 \\
\hline CAEW07(01) & $\mathrm{K}$ & 17475 & 37022 & 3289 & 35398 & 5.31 & 1.05 & & \\
\hline CAEW001) & $\mathrm{E}$ & 38727 & 82048 & 6438 & 69295 & 6.01 & 1.18 & 8029 & 17010 \\
\hline CAJS01(01) & $\mathrm{A}$ & & & 2090 & 22499 & & & & \\
\hline CAJS01(02) & $\mathrm{A}$ & & & 711 & 7650 & & & & \\
\hline CAJS01(03) & $\mathrm{A}$ & & & 711 & 7650 & & & & \\
\hline CAJS02(01) & $\mathrm{J}$ & 14169 & 30018 & 1260 & 13561 & 11.24 & 2.21 & 2834 & 6004 \\
\hline CAJS03(01) & $\mathrm{B}$ & 9295 & 19692 & 8242 & 88721 & 1.13 & 0.22 & 1394 & 2954 \\
\hline CAJS21(01) & $\mathrm{K}$ & 6718 & 14233 & 924 & 9950 & 7.27 & 1.43 & 1429 & 3027 \\
\hline CAJS21(02) & $\mathrm{K}$ & 4520 & 9576 & 831 & 8944 & 5.44 & 1.07 & 4520 & 9576 \\
\hline CAJS222(01) & $\mathrm{E}$ & 8973 & 19011 & 1901 & 20466 & 4.72 & 0.93 & 1039 & 2201 \\
\hline CAJS23(01) & $\mathrm{J}$ & 8312 & 17610 & 1044 & 11237 & 7.96 & 1.57 & 945 & 2001 \\
\hline CAJW18(01) & $\mathrm{D}$ & 8218 & 17410 & 1646 & 17719 & 4.99 & 0.98 & & \\
\hline CAJW18(02) & $\mathrm{L}$ & & & 572 & 6154 & & & & \\
\hline CAJW19(01) & $\mathrm{K}$ & 16199 & 34320 & 2650 & 28521 & 6.11 & 1.20 & & \\
\hline CAJW20(01) & $\mathrm{F}$ & 75566 & 160094 & 13889 & 149499 & 5.44 & 1.07 & 13224 & 28016 \\
\hline CAJW24(01) & $\mathrm{E}$ & 28337 & 60035 & 3790 & 40800 & 7.47 & 1.47 & & \\
\hline CAJW25(01) & $\mathrm{F}$ & 14742 & 31233 & 1183 & 12730 & 12.46 & 2.45 & & \\
\hline CAJW26(01) & $\mathrm{F}$ & 38539 & 81648 & 7153 & 77000 & 5.39 & 1.06 & & \\
\hline COAS02(01) & $\mathrm{D}$ & 19248 & 40779 & 3439 & 37018 & 5.60 & 1.10 & & \\
\hline COAS04(01) & $\mathrm{D}$ & 47229 & 100059 & 5086 & 54750 & 9.28 & 1.83 & 4723 & 10006 \\
\hline COAS06(01) & $\mathrm{F}$ & 9134 & 19352 & 1427 & 15363 & 6.40 & 1.26 & 850 & 1801 \\
\hline FLDW07(02) & $\mathrm{N}$ & 7745 & 16410 & 2076 & 22350 & 3.73 & 0.73 & 1495 & 3167 \\
\hline FLDW08(01) & $\mathrm{H}$ & 11160 & 23643 & 1636 & 17608 & 6.82 & 1.34 & 1086 & 2301 \\
\hline FLDW10(01) & $\mathrm{H}$ & 5904 & 12507 & 1556 & 16750 & 3.79 & 0.75 & 520 & 1101 \\
\hline FLGS01(01) & $\mathrm{E}$ & 10211 & 21633 & 1878 & 20220 & 5.43 & 1.07 & 1417 & 3002 \\
\hline FLGS04(01) & $\mathrm{N}$ & 6707 & 14208 & 989 & 10650 & 6.78 & 1.33 & 708 & 1501 \\
\hline FLGS04(02) & $\mathrm{N}$ & 6707 & 14208 & 989 & 10650 & 6.78 & 1.33 & 708 & 1501 \\
\hline FLGS11(01) & $\mathrm{H}$ & 5564 & 11787 & 1486 & 16000 & 3.74 & 0.74 & 331 & 700 \\
\hline FLGS11(02) & $\mathrm{H}$ & 5564 & 11787 & 1486 & 16000 & 3.74 & 0.74 & 331 & 700 \\
\hline FLGS12(01) & $\mathrm{N}$ & 11557 & 24484 & 1033 & 11119 & 11.19 & 2.20 & 1747 & 3702 \\
\hline GADS01(01) & $\mathrm{E}$ & 10296 & 21813 & 2392 & 25748 & 4.30 & 0.85 & 1015 & 2151 \\
\hline GADS02(01) & $\mathrm{E}$ & 6990 & 14809 & 1686 & 18145 & 4.15 & 0.82 & 945 & 2001 \\
\hline GADS02(02) & $\mathrm{E}$ & 6990 & 14809 & 1686 & 18145 & 4.15 & 0.82 & 945 & 2001 \\
\hline GADS03(01) & $\mathrm{A}$ & 9583 & 20303 & 2187 & 23538 & 4.38 & 0.86 & & \\
\hline
\end{tabular}




\begin{tabular}{|c|c|c|c|c|c|c|c|c|c|}
\hline \multirow[b]{2}{*}{ System ID } & \multirow{2}{*}{$\begin{array}{c}\text { System } \\
\text { type }\end{array}$} & \multicolumn{2}{|c|}{$\begin{array}{c}\text { Design supply airflow } \\
\text { capacity }\end{array}$} & \multicolumn{2}{|c|}{$\begin{array}{c}\text { Floor area served by } \\
\text { system }\end{array}$} & \multicolumn{2}{|c|}{$\begin{array}{c}\text { Design supply capacity } \\
\text { per unit floor area }\end{array}$} & \multicolumn{2}{|c|}{$\begin{array}{c}\text { Design minimum } \\
\text { outdoor air intake }\end{array}$} \\
\hline & & $\mathrm{L} / \mathrm{s}$ & $\mathrm{cfm}$ & $\mathrm{m}^{2}$ & $\mathrm{ft}^{2}$ & $\mathrm{~L} / \mathrm{s}-\mathrm{m}^{2}$ & $\mathrm{cfm} / \mathrm{ft}^{2}$ & $\mathrm{~L} / \mathrm{s}$ & $\mathrm{cfm}$ \\
\hline ILBS01(01) & $\mathrm{H}$ & & & 1190 & 12805 & & & & \\
\hline ILBS01(02) & $\mathrm{H}$ & & & 967 & 10407 & & & & \\
\hline ILBS02(01) & $\mathrm{L}$ & 8501 & 18011 & 1030 & 11086 & 8.25 & 1.62 & & \\
\hline ILBS03(01) & $\mathrm{N}$ & 13954 & 29562 & 2240 & 24111 & 6.23 & 1.23 & & \\
\hline LAGW04(01) & $\mathrm{O}$ & 9918 & 21012 & 1926 & 20736 & 5.15 & 1.01 & 945 & 2001 \\
\hline LAGW04(02) & $\mathrm{O}$ & 8973 & 19011 & 2093 & 22527 & 4.29 & 0.84 & 945 & 2001 \\
\hline LAGW05(01) & $\mathrm{N}$ & 6848 & 14508 & 372 & 4000 & 18.43 & 3.63 & 666 & 1411 \\
\hline LAGW05(02) & $\mathrm{N}$ & 4534 & 9606 & 1239 & 13337 & 3.66 & 0.72 & 453 & 960 \\
\hline LAGW06(01) & $\mathrm{D}$ & 6973 & 14773 & 2091 & 22511 & 3.33 & 0.66 & 589 & 1248 \\
\hline LAGW06(02) & $\mathrm{B}$ & 1417 & 3002 & 130 & 1394 & 10.94 & 2.15 & 119 & 253 \\
\hline MABW05(01) & $\mathrm{D}$ & 8995 & 19056 & 4151 & 44681 & 2.17 & 0.43 & & \\
\hline MABW05(02) & $\mathrm{D}$ & 9779 & 20717 & 3819 & 41112 & 2.56 & 0.50 & & \\
\hline MABW06(01) & $\mathrm{E}$ & 6612 & 14008 & 1259 & 13548 & 5.25 & 1.03 & 756 & 1601 \\
\hline MABW08(01) & $\mathrm{G}$ & 15637 & 33129 & 3736 & 40215 & 4.18 & 0.82 & 3903 & 8269 \\
\hline MABW08(02) & $\mathrm{B}$ & 12001 & 25425 & 4441 & 47807 & 2.70 & 0.53 & 11992 & 25406 \\
\hline MDDS01(01) & $\mathrm{B}$ & 24309 & 51500 & 4317 & 46464 & 5.63 & 1.11 & 12360 & 26185 \\
\hline MDDS03(01) & $\mathrm{A}$ & 2125 & 4502 & 868 & 9342 & 2.45 & 0.48 & 659 & 1396 \\
\hline MDDS03(02) & $\mathrm{A}$ & 1835 & 3887 & 692 & 7449 & 2.65 & 0.52 & & \\
\hline MDDS04(01) & $\mathrm{D}$ & 2942 & 6234 & 606 & 6526 & 4.85 & 0.96 & 283 & 600 \\
\hline MDDS04(02) & $\mathrm{D}$ & 3396 & 7194 & 629 & 6765 & 5.40 & 1.06 & 340 & 720 \\
\hline MIBW01(01) & $\mathrm{D}$ & 3627 & 7684 & 851 & 9159 & 4.26 & 0.84 & & \\
\hline MIBW01(02) & $\mathrm{D}$ & 3859 & 8175 & 808 & 8696 & 4.78 & 0.94 & & \\
\hline MIBW03(01) & $\mathrm{D}$ & 19364 & 41024 & 3902 & 42000 & 4.96 & 0.98 & 2834 & 6004 \\
\hline MIBW04(01) & $\mathrm{D}$ & 16530 & 35020 & 3409 & 36691 & 4.85 & 0.95 & 1577 & 3342 \\
\hline MIBW04(02) & $\mathrm{D}$ & 16530 & 35020 & 2454 & 26419 & 6.73 & 1.33 & 1360 & 2882 \\
\hline MNBW01(01) & $\mathrm{D}$ & 7080 & 15000 & 1514 & 16301 & 4.67 & 0.92 & 661 & 1400 \\
\hline MNBW02(01) & $\mathrm{D}$ & 6667 & 14125 & 1818 & 19572 & 3.67 & 0.72 & & \\
\hline MNBW02(02) & $\mathrm{D}$ & 6620 & 14025 & 1818 & 19572 & 3.64 & 0.72 & & \\
\hline MNBW04(01) & $\mathrm{D}$ & & & 3423 & 36843 & & & & \\
\hline MOCS01(01) & $\mathrm{D}$ & 30699 & 65038 & 9722 & 104650 & 3.16 & 0.62 & & \\
\hline MOCS05(01) & $\mathrm{D}$ & 70843 & 150088 & 14957 & 160999 & 4.74 & 0.93 & & \\
\hline NCDW02(01) & $\mathrm{D}$ & 26448 & 56033 & 5092 & 54812 & 5.19 & 1.02 & & \\
\hline NCDW02(02) & $\mathrm{D}$ & 26448 & 56033 & 5092 & 54812 & 5.19 & 1.02 & & \\
\hline NCDW03(01) & $\mathrm{A}$ & 595 & 1261 & 215 & 2315 & 2.77 & 0.54 & 76 & 160 \\
\hline NCDW03(02) & $\mathrm{A}$ & 595 & 1261 & 233 & 2511 & 2.55 & 0.50 & 76 & 160 \\
\hline NCDW03(03) & $\mathrm{A}$ & 595 & 1261 & 197 & 2117 & 3.02 & 0.60 & 76 & 160 \\
\hline NCDW03(04) & $\mathrm{A}$ & 520 & 1101 & 126 & 1360 & 4.11 & 0.81 & 61 & 130 \\
\hline NCDW03(05) & $\mathrm{D}$ & 520 & 1101 & 112 & 1200 & 4.66 & 0.92 & 61 & 130 \\
\hline NCDW06(01) & $\mathrm{G}$ & 14780 & 31313 & 2038 & 21933 & 7.25 & 1.43 & & \\
\hline NECW01(01) & $\mathrm{M}$ & 87373 & 185108 & 10116 & 108893 & 8.64 & 1.70 & & \\
\hline NECW02(01) & $\mathrm{L}$ & 70843 & 150088 & 8492 & 91410 & 8.34 & 1.64 & 56674 & 120070 \\
\hline NECW03(01) & $\mathrm{F}$ & 40617 & 86051 & 9748 & 104930 & 4.17 & 0.82 & & \\
\hline NMES01(01) & $\mathrm{H}$ & 2810 & 5953 & 803 & 8640 & 3.50 & 0.69 & & \\
\hline NMES01(02) & $\mathrm{H}$ & 5054 & 10706 & 1444 & 15540 & 3.50 & 0.69 & & \\
\hline NMES02(01) & $\mathrm{B}$ & 14594 & 30918 & 1229 & 13231 & 11.87 & 2.34 & & \\
\hline NMES03(01) & $\mathrm{D}$ & 7887 & 16710 & 1036 & 11150 & 7.61 & 1.50 & & \\
\hline NMES03(02) & $\mathrm{D}$ & 9304 & 19712 & 1289 & 13875 & 7.22 & 1.42 & & \\
\hline NVAW01(01) & $\mathrm{D}$ & 52702 & 111655 & 7623 & 82056 & 6.91 & 1.36 & & \\
\hline NVAW02(01) & $\mathrm{D}$ & 42817 & 90713 & 9711 & 104534 & 4.41 & 0.87 & 6140 & 13008 \\
\hline NVAW03(01) & $\mathrm{N}$ & 4605 & 9756 & 664 & 7152 & 6.93 & 1.36 & & \\
\hline NVAW03(02) & $\mathrm{N}$ & 1736 & 3677 & 338 & 3640 & 5.13 & 1.01 & & \\
\hline
\end{tabular}




\begin{tabular}{|c|c|c|c|c|c|c|c|c|c|}
\hline \multirow[b]{2}{*}{ System ID } & \multirow{2}{*}{$\begin{array}{c}\text { System } \\
\text { type }\end{array}$} & \multicolumn{2}{|c|}{$\begin{array}{c}\text { Design supply airflow } \\
\text { capacity }\end{array}$} & \multicolumn{2}{|c|}{$\begin{array}{c}\text { Floor area served by } \\
\text { system }\end{array}$} & \multicolumn{2}{|c|}{$\begin{array}{c}\text { Design supply capacity } \\
\text { per unit floor area }\end{array}$} & \multicolumn{2}{|c|}{$\begin{array}{l}\text { Design minimum } \\
\text { outdoor air intake }\end{array}$} \\
\hline & & $\mathrm{L} / \mathrm{s}$ & $\mathrm{cfm}$ & $\mathrm{m}^{2}$ & $\mathrm{ft}^{2}$ & $\mathrm{~L} / \mathrm{s}-\mathrm{m}^{2}$ & $\mathrm{cfm} / \mathrm{ft}^{2}$ & $\mathrm{~L} / \mathrm{s}$ & $\mathrm{cfm}$ \\
\hline NYBS01(01) & $\mathrm{E}$ & 35421 & 75044 & 7353 & 79150 & 4.82 & 0.95 & 11689 & 24765 \\
\hline NYBS01(02) & $\mathrm{E}$ & 18891 & 40023 & 3077 & 33119 & 6.14 & 1.21 & 5667 & 12007 \\
\hline NYBS02(01) & $\mathrm{N}$ & 2208 & 4678 & 517 & 5560 & 4.27 & 0.84 & & \\
\hline NYBS02(02) & $\mathrm{N}$ & 2310 & 4893 & 503 & 5416 & 4.59 & 0.90 & & \\
\hline NYBS04(01) & $\mathrm{D}$ & 9446 & 20012 & 1412 & 15199 & 6.69 & 1.32 & & \\
\hline NYBS04(02) & $\mathrm{D}$ & 9446 & 20012 & 1558 & 16766 & 6.06 & 1.19 & & \\
\hline NYBS05(01) & $\mathrm{F}$ & 6777 & 14358 & 2483 & 26726 & 2.73 & 0.54 & 678 & 1436 \\
\hline NYBS07(01) & $\mathrm{B}$ & 5667 & 12007 & 1084 & 11670 & 5.23 & 1.03 & & \\
\hline \begin{tabular}{|l|} 
ORIS03(01) \\
\end{tabular} & $\mathrm{K}$ & 22670 & 48028 & 4329 & 46602 & 5.24 & 1.03 & 2598 & 5503 \\
\hline ORIS03(03) & $\mathrm{K}$ & 22670 & 48028 & 2428 & 26138 & 9.33 & 1.84 & 2598 & 5503 \\
\hline ORIS04(01) & $\mathrm{O}$ & 7337 & 15544 & 1445 & 15552 & 5.08 & 1.00 & & \\
\hline \begin{tabular}{|l|} 
PABS03(01) \\
\end{tabular} & $\mathrm{D}$ & 22528 & 47728 & 5313 & 57185 & 4.24 & 0.83 & 2409 & 5103 \\
\hline PABS04(01) & $\mathrm{D}$ & 17985 & 38102 & 4323 & 46530 & 4.16 & 0.82 & 3306 & 7004 \\
\hline PABS04(02) & $\mathrm{A}$ & 7486 & 15859 & 248 & 2670 & 30.18 & 5.94 & & \\
\hline SCDW01(01) & $\mathrm{E}$ & 11099 & 23514 & 1380 & 14851 & 8.04 & 1.58 & 945 & 2001 \\
\hline SCDW02(01) & $\mathrm{F}$ & 18891 & 40023 & 11297 & 121600 & 1.67 & 0.33 & 2834 & 6004 \\
\hline SDBW01(01) & $\mathrm{E}$ & 9918 & 21012 & 2145 & 23088 & 4.62 & 0.91 & 1497 & 3172 \\
\hline SDBW02(01) & $\mathrm{G}$ & 9446 & 20012 & 1705 & 18350 & 5.54 & 1.09 & 945 & 2001 \\
\hline SDBW04(01) & $\mathrm{B}$ & 11335 & 24014 & 1480 & 15934 & 7.66 & 1.51 & & \\
\hline TNDS05(01) & $\mathrm{B}$ & 13130 & 27816 & 4451 & 47907 & 2.95 & 0.58 & 13130 & 27816 \\
\hline TNDS05(02) & $\mathrm{A}$ & 7745 & 16410 & 2684 & 28891 & 2.89 & 0.57 & 7745 & 16410 \\
\hline TNDS06(01) & $\mathrm{D}$ & 132127 & 279924 & 33783 & 363649 & 3.91 & 0.77 & 19246 & 40774 \\
\hline TNDS07(01) & $\mathrm{N}$ & 8501 & 18011 & 952 & 10242 & 8.93 & 1.76 & & \\
\hline \begin{tabular}{|l|} 
TNFS08(01) \\
\end{tabular} & $\mathrm{G}$ & 5904 & 12507 & 785 & 8447 & 7.52 & 1.48 & 590 & 1251 \\
\hline TNFS08(02) & $\mathrm{D}$ & 2739 & 5804 & 542 & 5832 & 5.06 & 1.00 & 425 & 900 \\
\hline \begin{tabular}{|l|l} 
TNFS09(01) \\
\end{tabular} & $\mathrm{G}$ & 8921 & 18901 & 1505 & 16200 & 5.93 & 1.17 & 1181 & 2501 \\
\hline \begin{tabular}{|l|l} 
TNFS09(02) \\
\end{tabular} & $\mathrm{G}$ & 6962 & 14749 & 1092 & 11750 & 6.38 & 1.26 & 708 & 1501 \\
\hline \begin{tabular}{|l} 
TNFS10 $(01)$ \\
\end{tabular} & $\mathrm{H}$ & 15420 & 32669 & 7312 & 78706 & 2.11 & 0.42 & 2928 & 6204 \\
\hline TXFS01(01) & $\mathrm{D}$ & 56561 & 119830 & 9652 & 103897 & 5.86 & 1.15 & 3840 & 8135 \\
\hline TXFS02(01) & $\mathrm{D}$ & 7793 & 16510 & 1373 & 14783 & 5.67 & 1.12 & & \\
\hline TXFS02(02) & $\mathrm{D}$ & 9210 & 19511 & 1483 & 15968 & 6.21 & 1.22 & & \\
\hline \begin{tabular}{|l|} 
TXFS07(01) \\
\end{tabular} & $\mathrm{H}$ & 51262 & 108604 & 10380 & 111734 & 4.94 & 0.97 & & \\
\hline TXFS08(01) & $\mathrm{H}$ & 7179 & 15209 & 1688 & 18165 & 4.25 & 0.84 & 548 & 1161 \\
\hline TXFS08(02) & $\mathrm{H}$ & 6976 & 14779 & 1718 & 18495 & 4.06 & 0.80 & 581 & 1231 \\
\hline TXFS09(01) & $\mathrm{D}$ & 4581 & 9706 & 1123 & 12086 & 4.08 & 0.80 & 583 & 1236 \\
\hline \begin{tabular}{|l|} 
TXFS09(02) \\
\end{tabular} & $\mathrm{D}$ & 5904 & 12507 & 1379 & 14844 & 4.28 & 0.84 & 763 & 1616 \\
\hline TXFW05(01) & $\mathrm{H}$ & 111932 & 237139 & 18792 & 202282 & 5.96 & 1.17 & & \\
\hline TXFW06(01) & $\mathrm{H}$ & 86797 & 183888 & 16357 & 176069 & 5.31 & 1.04 & & \\
\hline WAIW03(01) & $\mathrm{H}$ & 6612 & 14008 & 1985 & 21366 & 3.33 & 0.66 & 1984 & 4202 \\
\hline WAIW04(01) & $\mathrm{H}$ & 8973 & 19011 & 1730 & 18623 & 5.19 & 1.02 & & \\
\hline$\#$ of values & & 134 & 134 & 141 & 141 & 134 & 134 & 76 & 76 \\
\hline Mean & & 16097 & 34103 & 3098 & 33349 & 5.86 & 1.15 & 3269 & 6926 \\
\hline StdDev & & 21224 & 44964 & 4234 & 45579 & 3.57 & 0.70 & 7236 & 15331 \\
\hline Minimum & & 520 & 1101 & 112 & 1200 & 1.13 & 0.22 & 61 & 130 \\
\hline 10th percentile & & 2850 & 6037 & 542 & 5832 & 2.90 & 0.57 & 331 & 700 \\
\hline 25 th percentile & & 6612 & 14008 & 989 & 10650 & 4.15 & 0.82 & 642 & 1360 \\
\hline Median & & 8973 & 19011 & 1636 & 17608 & 5.21 & 1.03 & 1027 & 2176 \\
\hline 75th percentile & & 16059 & 34022 & 3439 & 37018 & 6.78 & 1.33 & 2834 & 6004 \\
\hline 90th percentile & & 38671 & 81928 & 7623 & 82056 & 8.45 & 1.66 & 7887 & 16710 \\
\hline Maximum & & 132127 & 279924 & 33783 & 363649 & 30.18 & 5.94 & 56674 & 120070 \\
\hline
\end{tabular}




\begin{tabular}{|c|c|c|c|c|c|c|c|c|c|c|c|}
\hline \multirow[b]{2}{*}{ System ID } & \multicolumn{2}{|c|}{$\begin{array}{l}\text { Design minimum } \\
\text { outdoor air intake } \\
\text { per unit floor area }\end{array}$} & \multirow{2}{*}{$\begin{array}{l}\text { Number of } \\
\text { occupants }\end{array}$} & \multicolumn{2}{|c|}{$\begin{array}{c}\text { Design minimum } \\
\text { OA per person }\end{array}$} & \multirow{2}{*}{$\begin{array}{c}\begin{array}{c}\text { Ratio of } \\
\text { design }\end{array} \\
\text { minimum OA } \\
\text { to supply } \\
\end{array}$} & \multicolumn{2}{|c|}{ Occupant density } & \multicolumn{2}{|c|}{$\begin{array}{c}\text { Design return fan } \\
\text { capacity }\end{array}$} & \multirow{2}{*}{$\begin{array}{c}\text { Ratio of } \\
\text { design } \\
\text { supply to } \\
\text { return } \\
\end{array}$} \\
\hline & $\mathrm{L} / \mathrm{s}-\mathrm{m}^{2}$ & $\mathrm{cfm} / \mathrm{ft}^{2}$ & & $\mathrm{cfm}$ & $\mathrm{L} / \mathrm{s}$ & & $/ 1000 \mathrm{ft}^{2}$ & $/ 100 \mathrm{~m}^{2}$ & $\mathrm{~L} / \mathrm{s}$ & $\mathrm{cfm}$ & \\
\hline ARFW01(01) & & & 46 & & & & 4.8 & 5.2 & & & \\
\hline ARFW01(02) & & & 46 & & & & 4.8 & 5.2 & & & \\
\hline ARFW02(01) & 0.19 & 0.04 & 60 & 25.0 & 11.8 & 0.07 & 1.5 & 1.6 & & & \\
\hline ARFW02(02) & 0.39 & 0.08 & 50 & 25.0 & 11.8 & 0.07 & 3.0 & 3.3 & & & \\
\hline ARFW03(01) & & & 44 & & & & 5.6 & 6.0 & & & \\
\hline ARFW03(02) & & & 32 & & & & 5.9 & 6.4 & & & \\
\hline AZHS02(01) & & & 42 & & & & 3.6 & 3.9 & & & \\
\hline $\mathrm{AZHSO2(02)}$ & & & 33 & & & & 3.6 & 3.9 & 6707 & 14208 & 1.06 \\
\hline AZHS04(01) & & & 68 & & & & 3.7 & 3.9 & & & \\
\hline AZHS04(02) & & & 12 & & & & 5.9 & 6.4 & & & \\
\hline AZHW10(01) & & & 35 & & & & 2.7 & 2.9 & & & \\
\hline AZHW10(02) & & & 19 & & & & 5.6 & 6.0 & & & \\
\hline AZHW11(01) & & & 113 & & & & 4.0 & 4.3 & & & \\
\hline AZHW12(01) & 0.29 & 0.06 & 94 & 24.3 & 11.5 & 0.14 & 2.3 & 2.5 & & & \\
\hline AZHW12(02) & 0.34 & 0.07 & 45 & 50.7 & 23.9 & 0.14 & 1.3 & 1.4 & & & \\
\hline CAES17(01) & 1.20 & 0.24 & 70 & 53.2 & 25.1 & 0.15 & 4.5 & 4.8 & & & \\
\hline CAEW07(01) & & & 95 & & & & 2.7 & 2.9 & 12752 & 27016 & 1.37 \\
\hline CAEW001) & 1.25 & 0.25 & 150 & 113.4 & 53.5 & 0.21 & 2.2 & 2.3 & 30699 & 65038 & 1.26 \\
\hline CAJS01(01) & & & 52 & & & & 2.3 & 2.5 & & & \\
\hline CAJS01(02) & & & 30 & & & & 3.9 & 4.2 & & & \\
\hline CAJS01(03) & & & 12 & & & & 1.6 & 1.7 & & & \\
\hline CAJS02(01) & 2.25 & 0.44 & 111 & 54.1 & 25.5 & 0.20 & 8.2 & 8.8 & & & \\
\hline CAJS03(01) & 0.17 & 0.03 & 155 & 19.1 & 9.0 & 0.15 & 1.7 & 1.9 & 47229 & 100059 & 0.20 \\
\hline CAJS21(01) & 1.55 & 0.30 & 50 & 60.5 & 28.6 & 0.21 & 5.0 & 5.4 & 5290 & 11207 & 1.27 \\
\hline CAJS21(02) & & 1.07 & 46 & 208.2 & 98.2 & 1.00 & 5.1 & 5.5 & & & \\
\hline CAJS222(01) & 0.55 & 0.11 & 183 & 12.0 & 5.7 & 0.12 & 8.9 & 9.6 & & & \\
\hline CAJS23(01) & 0.90 & 0.18 & 73 & 27.4 & 12.9 & 0.11 & 6.5 & 7.0 & & & \\
\hline CAJW18(01) & & & 59 & & & & 3.3 & 3.6 & & & \\
\hline \multicolumn{12}{|l|}{ CAJW18(02) } \\
\hline CAJW19(01) & & & 92 & & & & 3.2 & 3.5 & 15349 & 32519 & 1.06 \\
\hline CAJW20(01) & 0.95 & 0.19 & 741 & 37.8 & 17.8 & 0.17 & 5.0 & 5.3 & 68009 & 144084 & 1.11 \\
\hline CAJW24(01) & & & 224 & & & & 5.5 & 5.9 & 25504 & 54032 & 1.11 \\
\hline CAJW25(01) & & & 770 & & & & 60.5 & & 12586 & 26666 & 1.17 \\
\hline CAJW26(01) & & & 420 & & & & 5.5 & 5.9 & 30472 & 64558 & 1.26 \\
\hline COAS02(01) & & & 133 & & & & 3.6 & 3.9 & & & \\
\hline COAS04(01) & 0.93 & 0.18 & 310 & 32.3 & 15.2 & 0.10 & 5.7 & 6.1 & 42506 & 90053 & 1.11 \\
\hline COAS06(01) & 0.60 & 0.12 & 55 & 32.7 & 15.5 & 0.09 & 3.6 & 3.9 & & & \\
\hline FLDW07(02) & 0.72 & 0.14 & 50 & 63.3 & 29.9 & 0.19 & 2.2 & 2.4 & & & \\
\hline FLDW08(01) & 0.66 & 0.13 & 69 & 33.4 & 15.7 & 0.10 & 3.9 & 4.2 & & & \\
\hline FLDW10(01) & 0.33 & 0.07 & 108 & 10.2 & 4.8 & 0.09 & 6.4 & 6.9 & & & \\
\hline FLGS01(01) & 0.75 & 0.15 & 70 & 42.9 & 20.2 & 0.14 & 3.5 & 3.7 & & & \\
\hline FLGS04(01) & 0.72 & 0.14 & 50 & 30.0 & 14.2 & 0.11 & 4.7 & 5.1 & & & \\
\hline FLGS04(02) & 0.72 & 0.14 & 50 & 30.0 & 14.2 & 0.11 & 4.7 & 5.1 & & & \\
\hline FLGS11(01) & 0.22 & 0.04 & 44 & 15.9 & 7.5 & 0.06 & 2.8 & 3.0 & & & \\
\hline FLGS11(02) & 0.22 & 0.04 & 46 & 15.2 & 7.2 & 0.06 & 2.9 & 3.1 & & & \\
\hline FLGS12(01) & 1.69 & 0.33 & 60 & 61.7 & 29.1 & 0.15 & 5.4 & 5.8 & & & \\
\hline GADS01(01) & 0.42 & 0.08 & 67 & 32.1 & 15.2 & 0.10 & 2.6 & 2.8 & & & \\
\hline GADS02(01) & 0.56 & 0.11 & 40 & 50.0 & 23.6 & 0.14 & 2.2 & 2.4 & & & \\
\hline GADS02(02) & 0.56 & 0.11 & 40 & 50.0 & 23.6 & 0.14 & 2.2 & 2.4 & & & \\
\hline GADS03(01) & & & 124 & & & & 5.3 & 5.7 & & & \\
\hline
\end{tabular}




\begin{tabular}{|c|c|c|c|c|c|c|c|c|c|c|c|}
\hline \multirow[b]{2}{*}{ System ID } & \multicolumn{2}{|c|}{$\begin{array}{c}\text { Design minimum } \\
\text { outdoor air intake per } \\
\text { unit floor area }\end{array}$} & \multirow{2}{*}{$\begin{array}{c}\text { Number } \\
\text { of } \\
\text { occupants }\end{array}$} & \multicolumn{2}{|c|}{$\begin{array}{c}\text { Design } \\
\text { minimum OA } \\
\text { per person }\end{array}$} & \multirow{2}{*}{\begin{tabular}{|c|} 
Ratio of \\
design \\
minimum OA \\
to supply
\end{tabular}} & \multicolumn{2}{|c|}{ Occupant density } & \multicolumn{2}{|c|}{\begin{tabular}{|c|} 
Design return fan \\
capacity
\end{tabular}} & \multirow{2}{*}{$\begin{array}{c}\text { Ratio of } \\
\text { design } \\
\text { supply to } \\
\text { return }\end{array}$} \\
\hline & $\mathrm{L} / \mathrm{s}-\mathrm{m}^{2}$ & $\mathrm{cfm} / \mathrm{ft}^{2}$ & & $\mathrm{cfm}$ & $\mathrm{L} / \mathrm{s}$ & & $/ 1000 \mathrm{ft}^{2}$ & $/ 100 \mathrm{~m}^{2}$ & $\mathrm{~L} / \mathrm{s}$ & $\mathrm{cfm}$ & \\
\hline ILBS01(01) & & & 35 & & & & 2.7 & 2.9 & & & \\
\hline ILBS01(02) & & & 51 & & & & 4.9 & 5.3 & & & \\
\hline ILBS02(01) & & & 45 & & & & 4.1 & 4.4 & 7793 & 16510 & 1.09 \\
\hline ILBS03(01) & & & 63 & & & & 2.6 & 2.8 & & & \\
\hline LAGW04(01) & 0.49 & 0.10 & 40 & 50.0 & 23.6 & 0.10 & 1.9 & 2.1 & & & \\
\hline LAGW04(02) & 0.45 & 0.09 & 33 & 60.6 & 28.6 & 0.11 & 1.5 & 1.6 & & & \\
\hline LAGW05(01) & 1.79 & 0.35 & 42 & 33.6 & 15.9 & 0.10 & 10.5 & 11.3 & & & \\
\hline LAGW05(02) & 0.37 & 0.07 & 30 & 32.0 & 15.1 & 0.10 & 2.2 & 2.4 & & & \\
\hline LAGW06(01) & 0.28 & 0.06 & 66 & 18.9 & 8.9 & 0.08 & 2.9 & 3.2 & & & \\
\hline LAGW06(02) & 0.92 & 0.18 & & & & 0.08 & & & & & \\
\hline MABW05(01) & & & 120 & & & & 2.7 & 2.9 & 8180 & 17330 & 1.10 \\
\hline MABW05(02) & & & 120 & & & & 2.9 & 3.1 & 8426 & 17851 & 1.16 \\
\hline MABW06(01) & 0.60 & 0.12 & 50 & 32.0 & 15.1 & 0.11 & 3.7 & 4.0 & 4362 & 9240 & 1.52 \\
\hline MABW08(01) & 1.04 & 0.21 & 420 & 19.7 & 9.3 & 0.25 & 10.4 & 11.2 & 16105 & 34120 & 0.97 \\
\hline MABW08(02) & 2.70 & 0.53 & 408 & 62.3 & 29.4 & 1.00 & 8.5 & 9.2 & & & \\
\hline MDDS01(01) & 2.86 & 0.56 & 241 & 108.7 & 51.3 & 0.51 & 5.2 & 5.6 & & & \\
\hline MDDS03(01) & 0.76 & 0.15 & 51 & 27.4 & 12.9 & 0.31 & 5.5 & 5.9 & & & \\
\hline MDDS03(02) & & & 33 & & & & 4.4 & 4.8 & & & \\
\hline MDDS04(01) & 0.47 & 0.09 & 44 & 13.6 & 6.4 & 0.10 & 6.7 & 7.3 & & & \\
\hline MDDS04(02) & 0.54 & 0.11 & 24 & 30.0 & 14.2 & 0.10 & 3.5 & 3.8 & & & \\
\hline MIBW01(01) & & & 45 & & & & 4.9 & 5.3 & 3254 & 6894 & 1.11 \\
\hline MIBW01(02) & & & 34 & & & & 3.9 & 4.2 & 3171 & 6719 & 1.22 \\
\hline MIBW03(01) & 0.73 & 0.14 & 373 & 16.1 & 7.6 & 0.15 & 8.9 & 9.6 & 17427 & 36922 & 1.11 \\
\hline MIBW04(01) & 0.46 & 0.09 & 172 & 19.4 & 9.2 & 0.10 & 4.7 & 5.0 & 14953 & 31678 & 1.11 \\
\hline MIBW04(02) & 0.55 & 0.11 & 172 & 16.8 & 7.9 & 0.08 & 6.5 & 7.0 & 15170 & 32139 & 1.09 \\
\hline MNBW01(01) & 0.44 & 0.09 & 45 & 31.1 & 14.7 & 0.09 & 2.8 & 3.0 & & & \\
\hline MNBW02(01) & & & 37 & & & & 1.9 & 2.0 & & & \\
\hline MNBW02(02) & & & 31 & & & & 1.6 & 1.7 & & & \\
\hline MNBW04(01) & & & 87 & & & & 2.4 & 2.5 & & & \\
\hline MOCS01(01) & & & 295 & & & & 2.8 & 3.0 & 25976 & 55032 & 1.18 \\
\hline MOCS05(01) & & & 374 & & & & 2.3 & 2.5 & & & \\
\hline NCDW02(01) & & & 110 & & & & 2.0 & 2.2 & & & \\
\hline NCDW02(02) & & & 113 & & & & 2.1 & 2.2 & & & \\
\hline NCDW03(01) & 0.35 & 0.07 & 7 & 22.9 & 10.8 & 0.13 & 3.0 & 3.3 & & & \\
\hline NCDW03(02) & 0.32 & 0.06 & 2 & 80.0 & 37.8 & 0.13 & 0.8 & 0.9 & & & \\
\hline NCDW03(03) & 0.38 & 0.08 & 8 & 20.0 & 9.4 & 0.13 & 3.8 & 4.1 & & & \\
\hline NCDW03(04) & 0.49 & 0.10 & 4 & 32.5 & 15.3 & 0.12 & 2.9 & 3.2 & & & \\
\hline NCDW03(05) & 0.55 & 0.11 & 4 & 32.5 & 15.3 & 0.12 & 3.3 & 3.6 & & & \\
\hline NCDW06(01) & & & 60 & & & & 2.7 & 2.9 & & & \\
\hline NECW01(01) & & & 893 & & & & 8.2 & 8.8 & 47229 & 100059 & 1.85 \\
\hline NECW02(01) & 6.67 & 1.31 & 1500 & 80.0 & 37.8 & 0.80 & 16.4 & 17.7 & 56674 & 120070 & 1.25 \\
\hline NECW03(01) & & & 921 & & & & 8.8 & 9.4 & 36366 & 77045 & 1.12 \\
\hline NMES01(01) & & & 12 & & & & 1.4 & 1.5 & 2782 & 5893 & 1.01 \\
\hline NMES01(02) & & & 41 & & & & 2.6 & 2.8 & 5001 & 10596 & 1.01 \\
\hline NMES02(01) & & & 77 & & & & 5.8 & 6.3 & & & \\
\hline NMES03(01) & & & 20 & & & & 1.8 & 1.9 & & & \\
\hline NMES03(02) & & & 45 & & & & 3.2 & 3.5 & & & \\
\hline NVAW01(01) & & & 359 & & & & 4.4 & 4.7 & & & \\
\hline NVAW02(01) & 0.63 & 0.12 & 393 & 33.1 & 15.6 & 0.14 & 3.8 & 4.0 & 39700 & 84109 & 1.08 \\
\hline NVAW03(01) & & & 36 & & & & 5.0 & 5.4 & 3674 & 7784 & 1.25 \\
\hline NVAW03(02) & & & 12 & & & & 3.3 & 3.5 & 1193 & 2527 & 1.46 \\
\hline
\end{tabular}




\begin{tabular}{|c|c|c|c|c|c|c|c|c|c|c|c|}
\hline \multirow[b]{2}{*}{ System ID } & \multicolumn{2}{|c|}{\begin{tabular}{|c|} 
Design minimum \\
outdoor air intake per \\
unit floor area
\end{tabular}} & \multirow{2}{*}{$\begin{array}{c}\text { Number } \\
\text { of } \\
\text { occupants }\end{array}$} & \multicolumn{2}{|c|}{$\begin{array}{c}\text { Design } \\
\text { minimum OA } \\
\text { per person } \\
\end{array}$} & \multirow{2}{*}{\begin{tabular}{|c|}
$\begin{array}{c}\text { Ratio of } \\
\text { design } \\
\text { minimum OA } \\
\text { to supply }\end{array}$ \\
\end{tabular}} & \multicolumn{2}{|c|}{ Occupant density } & \multicolumn{2}{|c|}{$\begin{array}{c}\text { Design return fan } \\
\text { capacity }\end{array}$} & \multirow{2}{*}{$\begin{array}{c}\text { Ratio of } \\
\text { design } \\
\text { supply to } \\
\text { return }\end{array}$} \\
\hline & $\mathrm{L} / \mathrm{s}-\mathrm{m}^{2}$ & $\mathrm{cfm} / \mathrm{ft}^{2}$ & & $\mathrm{cfm}$ & $\mathrm{L} / \mathrm{s}$ & & $/ 1000 \mathrm{ft}^{2}$ & $/ 100 \mathrm{~m}^{2}$ & $\mathrm{~L} / \mathrm{s}$ & $\mathrm{cfm}$ & \\
\hline NYBS01(01) & 1.59 & 0.31 & 618 & 40.1 & 18.9 & 0.33 & 7.8 & 8.4 & & & \\
\hline NYBS01(02) & 1.84 & 0.36 & 332 & 36.2 & 17.1 & 0.30 & 10.0 & 10.8 & & & \\
\hline NYBS02(01) & & & 40 & & & & 7.2 & 7.7 & & & \\
\hline NYBS02(02) & & & 28 & & & & 5.2 & 5.6 & & & \\
\hline NYBS04(01) & & & 50 & & & & 3.3 & 3.5 & 8501 & 18011 & 1.11 \\
\hline NYBS04(02) & & & 70 & & & & 4.2 & 4.5 & 8501 & 18011 & 1.11 \\
\hline NYBS05(01) & 0.27 & 0.05 & 160 & 9.0 & 4.2 & 0.10 & 6.0 & 6.4 & 5313 & 11257 & 1.28 \\
\hline NYBS07(01) & & & 65 & & & & 5.6 & 6.0 & & & \\
\hline ORIS03(01) & 0.60 & 0.12 & 171 & 32.2 & 15.2 & 0.11 & 3.7 & 3.9 & & & \\
\hline ORIS03(03) & 1.07 & 0.21 & 82 & 67.1 & 31.7 & 0.11 & 3.1 & 3.4 & & & \\
\hline ORIS04(01) & & & 67 & & & & 4.3 & 4.6 & & & \\
\hline PABS03(01) & 0.45 & 0.09 & 350 & 14.6 & 6.9 & 0.11 & 6.1 & 6.6 & & & \\
\hline PABS04(01) & 0.76 & 0.15 & 195 & 35.9 & 17.0 & 0.18 & 4.2 & 4.5 & 14169 & 30018 & 1.27 \\
\hline PABS04(02) & & & & & & & & & 6966 & 14759 & 1.07 \\
\hline SCDW01(01) & 0.68 & 0.13 & 90 & 22.2 & 10.5 & 0.09 & 6.1 & 6.5 & 10154 & 21513 & 1.09 \\
\hline SCDW02(01) & 0.25 & 0.05 & 160 & 37.5 & 17.7 & 0.15 & 1.3 & 1.4 & 16530 & 35020 & 1.14 \\
\hline SDBW01(01) & 0.70 & 0.14 & 61 & 52.0 & 24.5 & 0.15 & 2.6 & 2.8 & 9587 & 20312 & 1.03 \\
\hline SDBW02(01) & 0.55 & 0.11 & 700 & 2.9 & 1.3 & 0.10 & 38.1 & 41.1 & & & \\
\hline SDBW04(01) & & & 57 & & & & 3.6 & 3.9 & 11335 & 24014 & 1.00 \\
\hline TNDS05(01) & 2.95 & 0.58 & 575 & 48.4 & 22.8 & 1.00 & 12.0 & 12.9 & & & \\
\hline TNDS05(02) & 2.89 & 0.57 & & & & 1.00 & & & & & \\
\hline TNDS06(01) & 0.57 & 0.11 & 1067 & 38.2 & 18.0 & 0.15 & 2.9 & 3.2 & & & \\
\hline TNDS07(01) & & & 55 & & & & 5.4 & 5.8 & & & \\
\hline TNFS08(01) & 0.75 & 0.15 & 46 & 27.2 & 12.8 & 0.10 & 5.4 & 5.9 & & & \\
\hline TNFS08(02) & 0.78 & 0.15 & 29 & 31.0 & 14.7 & 0.16 & 5.0 & 5.4 & & & \\
\hline TNFS09(01) & 0.78 & 0.15 & 104 & 24.1 & 11.4 & 0.13 & 6.4 & 6.9 & & & \\
\hline TNFS09(02) & 0.65 & 0.13 & 68 & 22.1 & 10.4 & 0.10 & 5.8 & 6.2 & & & \\
\hline TNFS10(01) & 0.40 & 0.08 & 86 & 72.1 & 34.0 & 0.19 & 1.1 & 1.2 & & & \\
\hline TXFS01(01) & 0.40 & 0.08 & 348 & 23.4 & 11.0 & 0.07 & 3.3 & 3.6 & & & \\
\hline TXFS02(01) & & & 42 & & & & 2.8 & 3.1 & & & \\
\hline TXFS02(02) & & & 49 & & & & 3.1 & 3.3 & & & \\
\hline TXFS07(01) & & & 362 & & & & 3.2 & 3.5 & & & \\
\hline TXFS08(01) & 0.32 & 0.06 & 59 & 19.7 & 9.3 & 0.08 & 3.2 & 3.5 & & & \\
\hline TXFS08(02) & 0.34 & 0.07 & 53 & 23.2 & 11.0 & 0.08 & 2.9 & 3.1 & & & \\
\hline TXFS09(01) & 0.52 & 0.10 & 60 & 20.6 & 9.7 & 0.13 & 5.0 & 5.3 & & & \\
\hline TXFS09(02) & 0.55 & 0.11 & 33 & 49.0 & 23.1 & 0.13 & 2.2 & 2.4 & & & \\
\hline TXFW05(01) & & & 515 & & & & 2.5 & 2.7 & 111460 & 236138 & 1.00 \\
\hline TXFW06(01) & & & 495 & & & & 2.8 & 3.0 & 86797 & 183888 & 1.00 \\
\hline WAIW03(01) & 1.00 & 0.20 & 77 & 54.6 & 25.8 & 0.30 & 3.6 & 3.9 & & & \\
\hline WAIW04(01) & & & 54 & & & & 2.9 & 3.1 & & & \\
\hline
\end{tabular}

\begin{tabular}{|l|c|c|c|c|c|c|c|c|c|c|c|}
\hline \# of values & 76 & 76 & 137 & 74 & 74 & 76 & 137 & 137 & 41 & 41 & 41 \\
\hline Mean & 0.94 & 0.18 & 154 & 39.0 & 18.4 & 0.19 & 4.9 & 5.3 & 22045 & 46705 & 1.14 \\
\hline StdDev & 1.06 & 0.21 & 229 & 29.0 & 13.7 & 0.22 & 6.1 & 6.5 & 24074 & 51003 & 0.22 \\
\hline Minimum & 0.17 & 0.03 & 2 & 2.9 & 1.3 & 0.06 & 0.8 & 0.9 & 1193 & 2527 & 0.20 \\
\hline 10th percentile & 0.31 & 0.06 & 30 & 16.0 & 7.5 & 0.08 & 2.0 & 2.2 & 3674 & 7784 & 1.00 \\
\hline 25th percentile & 0.42 & 0.08 & 42 & 22.4 & 10.6 & 0.10 & 2.7 & 2.9 & 6966 & 14759 & 1.07 \\
\hline Median & 0.60 & 0.12 & 60 & 32.1 & 15.2 & 0.12 & 3.7 & 3.9 & 12752 & 27016 & 1.11 \\
\hline 75th percentile & 0.92 & 0.18 & 150 & 50.0 & 23.6 & 0.15 & 5.4 & 5.9 & 30472 & 64558 & 1.25 \\
\hline 90th percentile & 1.82 & 0.36 & 339 & 63.0 & 29.7 & 0.31 & 7.4 & 8.0 & 47229 & 100059 & 1.28 \\
\hline Maximum & 6.67 & 1.31 & 1500 & 208.2 & 98.3 & 1.00 & 60.5 & 65.1 & 111460 & 236138 & 1.85 \\
\hline
\end{tabular}




\section{Appendix C: Volumetric Airflow Data Issues}

This appendix describes measurement issues identified with the volumetric airflow data and any adjustments that were made to account for these issues.

\begin{tabular}{|c|c|c|}
\hline Building & Measurement Issue & Data adjustment \\
\hline ARFW02 & $\begin{array}{l}\text { Wednesday a.m. volumetric outdoor air value for } \\
\text { system \#2 significantly below other measured values for } \\
\text { that system, while outdoor air fraction for this time } \\
\text { period based on } \mathrm{CO}_{2} \text { consistent with other values. }\end{array}$ & $\begin{array}{l}\text { Delete suspect value, no } \\
\text { study space volumetric } \\
\text { outdoor airflow for } \\
\text { Wednesday a.m. }\end{array}$ \\
\hline AZHS04 & $\begin{array}{l}\text { System \#1 measured recirculation airflow greater than } \\
\text { supply airflow for } 3 \text { of } 4 \text { readings, leading to negative } \\
\text { values for outdoor airflow; not significantly different } \\
\text { from zero based on uncertainty in recirculation and } \\
\text { supply airflows. }\end{array}$ & $\begin{array}{l}\text { Set system \#1 outdoor } \\
\text { airflow equal to zero in } \\
\text { those } 3 \text { cases. }\end{array}$ \\
\hline AZHW10 & $\begin{array}{l}\text { No outdoor airflow measurement on System \#2, but } \\
\text { System \#1 outdoor airflow values very close to sum of } \\
\text { supply airflows for System \#1 and \#2; survey notes } \\
\text { indicate common outdoor air intake for both systems. }\end{array}$ & $\begin{array}{l}\text { Calculate study space } \\
\text { outdoor airflow based on } \\
\text { System \#1 values alone. }\end{array}$ \\
\hline CAJS01 & $\begin{array}{l}\text { No outdoor airflow measurement on System \#1 of three } \\
\text { systems; all systems are } 100 \% \text { outdoor air; note that } \\
\text { System \#1 supply airflow is only about } 10 \% \text { of supply } \\
\text { airflow of other two systems. }\end{array}$ & $\begin{array}{l}\text { Assume System \#1 outdoor } \\
\text { airflow equals supply } \\
\text { airflow. }\end{array}$ \\
\hline CAJW18 & $\begin{array}{l}\text { Two systems listed under system design information, } \\
\text { but no design or measured data on System \#2; survey } \\
\text { notes indicate that System \#2 is heating only and wasn't } \\
\text { operating during test week. }\end{array}$ & $\begin{array}{l}\text { Results based on System } \\
\# 1 \text { measurements alone. }\end{array}$ \\
\hline CAJW26 & $\begin{array}{l}\text { Volumetric outdoor air fraction greater than } 100 \% \text { for } 3 \\
\text { of } 4 \text { readings, but not significantly different from } 100 \% \\
\text { based on uncertainty. }\end{array}$ & $\begin{array}{l}\text { Use the } 3 \text { calculated values } \\
\text { greater than } 100 \% \text {. }\end{array}$ \\
\hline COAS04 & $\begin{array}{l}\text { Measured recirculation airflow greater than supply } \\
\text { airflow for one reading, leading to negative value for } \\
\text { outdoor airflow; not significantly different from zero } \\
\text { based on uncertainty in recirculation and supply } \\
\text { airflows. }\end{array}$ & $\begin{array}{l}\text { Set value of outdoor } \\
\text { airflow equal to zero in that } \\
\text { case. }\end{array}$ \\
\hline ILBS01 & $\begin{array}{l}\text { Volumetric measurements of supply airflow only for } \\
\text { both systems; survey notes indicate outdoor air intake } \\
\text { damper closed during test week; outdoor airflows can } \\
\text { only be determined by product of supply airflow and } \\
\text { outdoor air fraction from } \mathrm{CO}_{2} \text {. }\end{array}$ & $\begin{array}{l}\text { No adjustments made to } \\
\text { data. }\end{array}$ \\
\hline LAGW05 & $\begin{array}{l}\text { Volumetric supply airflow values measured for both } \\
\text { systems, outdoor airflow values for System \#2 are } \\
\text { duplicates of System \#1 values; survey notes indicate } \\
\text { common outdoor air intake serves both systems. }\end{array}$ & $\begin{array}{l}\text { Use System \#1 values } \\
\text { alone to determine outdoor } \\
\text { air fraction and study space } \\
\text { outdoor airflow. }\end{array}$ \\
\hline LAGW06 & $\begin{array}{l}\text { No volumetric supply airflow values and only one } \\
\text { outdoor airflow value for System \#2; survey notes } \\
\text { indicate that System \#2 does not always operate and that } \\
\text { common outdoor air intake serves both systems; System } \\
\# 2 \text { design supply capacity and minimum outdoor air } \\
\text { only } 20 \% \text { of System \#1. }\end{array}$ & $\begin{array}{l}\text { Add single System \#2 } \\
\text { outdoor airflow to } \\
\text { corresponding System \#1 } \\
\text { value when calculating } \\
\text { study space outdoor } \\
\text { airflow. }\end{array}$ \\
\hline MABW05 & $\begin{array}{l}\text { One System \#2 measured recirculation airflow value } \\
\text { greater than supply airflow, leading to negative value }\end{array}$ & $\begin{array}{l}\text { Set value of outdoor } \\
\text { airflow equal to zero. }\end{array}$ \\
\hline
\end{tabular}




\begin{tabular}{|c|c|c|}
\hline & $\begin{array}{l}\text { for outdoor airflow; not significantly different from zero } \\
\text { based on uncertainty in recirculation and supply } \\
\text { airflows. }\end{array}$ & \\
\hline MDDS01 & $\begin{array}{l}\text { Measured recirculation airflow greater than supply } \\
\text { airflow for two readings, leading to negative values for } \\
\text { outdoor airflow; not significantly different from zero } \\
\text { based on assumed uncertainty in recirculation and } \\
\text { supply airflows. }\end{array}$ & $\begin{array}{l}\text { Set value of outdoor } \\
\text { airflow equal to zero for } \\
\text { these two events. }\end{array}$ \\
\hline NCDW03 & $\begin{array}{l}\text { Five systems; survey notes indicate outdoor air not } \\
\text { operated during study week; } 5 \text { of } 20 \text { potential outdoor } \\
\text { airflow values listed, could be leakage into system. }\end{array}$ & $\begin{array}{l}\text { No volumetric airflow rates } \\
\text { calculated for the study } \\
\text { space. }\end{array}$ \\
\hline NMES02 & $\begin{array}{l}\text { All } 4 \text { volumetric outdoor airflows greater than } \\
\text { volumetric supply airflows; outdoor air fraction } \\
\text { significantly greater than } 100 \% \text { based on measurement } \\
\text { uncertainty for only } 1 \text { of the } 4 \text { values. }\end{array}$ & $\begin{array}{l}\text { Use all values as } \\
\text { calculated. }\end{array}$ \\
\hline NVAW03 & $\begin{array}{l}\text { System \#1 measured outdoor airflows greater than } \\
\text { supply airflow for all } 4 \text { readings, leading to volumetric } \\
\text { outdoor air fraction greater than } 100 \% \text {, but not } \\
\text { significantly greater. }\end{array}$ & $\begin{array}{l}\text { No adjustments made to } \\
\text { data. }\end{array}$ \\
\hline NYBS04 & $\begin{array}{l}\text { Thursday a.m. volumetric outdoor airflow for system \#1 } \\
\text { much higher than other values for both systems \#1 and } \\
\# 2 \text {. }\end{array}$ & $\begin{array}{l}\text { No adjustments made to } \\
\text { data. }\end{array}$ \\
\hline ORIS03 & $\begin{array}{l}\text { No volumetric outdoor airflows for System \#3; survey } \\
\text { notes indicate outdoor air intake serves both systems \#1 } \\
\text { and \#3. }\end{array}$ & $\begin{array}{l}\text { Supply airflow for system } \\
\# 1 \text { based on sum of system } \\
\# 1 \text { and } \# 3 \text { values; outdoor } \\
\text { airflow based on System \#1 } \\
\text { values. }\end{array}$ \\
\hline ORIS04 & $\begin{array}{l}\text { No volumetric outdoor or recirculation airflow values; } \\
\text { survey notes indicate outdoor air damper location } \\
\text { prevented reliable traverse.. }\end{array}$ & $\begin{array}{l}\text { Outdoor airflow from } \mathrm{CO}_{2} \\
\text { ratio only. }\end{array}$ \\
\hline PABS03 & $\begin{array}{l}\text { Measured recirculation airflow greater than supply } \\
\text { airflow for all four readings, leading to negative values } \\
\text { for outdoor airflow; not significantly different from zero } \\
\text { based on assumed uncertainty in recirculation and } \\
\text { supply airflows. }\end{array}$ & $\begin{array}{l}\text { Set all } 4 \text { values of outdoor } \\
\text { airflow equal to zero. }\end{array}$ \\
\hline
\end{tabular}




\section{Appendix D: Measured Data for Air Handlers}

This appendix presents the following information for the measurements in the air handlers serving the study spaces:

\section{System ID}

Day and time of measurement

Supply, outdoor and recirculation airflows, and associated uncertainties (values in italics were not measured directly but were derived from other airflow rates, i.e., supply $=$ outdoor air + recirculation; outdoor air $=$ supply - recirculation)

Outdoor air fraction, based on volumetric and carbon dioxide ratio methods, and associated uncertainties 


\begin{tabular}{|c|c|c|c|c|c|c|c|c|c|}
\hline \multirow[b]{2}{*}{ System ID } & \multirow[b]{2}{*}{ Day Period } & \multicolumn{2}{|c|}{ Supply airflow } & \multicolumn{2}{|c|}{$\begin{array}{l}\text { Uncertainty in } \\
\text { supply airflow }\end{array}$} & \multicolumn{2}{|c|}{ Outdoor airflow } & \multicolumn{2}{|c|}{$\begin{array}{c}\begin{array}{c}\text { Uncertainty in outdoor } \\
\text { airflow }\end{array} \\
\end{array}$} \\
\hline & & $\mathrm{L} / \mathrm{s}$ & $\mathrm{cfm}$ & $\mathrm{L} / \mathrm{s}$ & $\mathrm{cfm}$ & $\mathrm{L} / \mathrm{s}$ & $\mathrm{cfm}$ & $\mathrm{L} / \mathrm{s}$ & $\mathrm{cfm}$ \\
\hline \multirow[t]{4}{*}{ ARFW01(01) } & Wed AM & 6919 & 14658 & 692 & 1466 & 385 & 815 & 115 & 245 \\
\hline & Wed PM & 6703 & 14200 & 670 & 1420 & 363 & 768 & 109 & 231 \\
\hline & Thurs AM & 6583 & 13946 & 658 & 1395 & 370 & 784 & 111 & 235 \\
\hline & Thurs PM & 6655 & 14099 & 665 & 1410 & 363 & 768 & 109 & 231 \\
\hline \multirow[t]{4}{*}{ ARFW01(02) } & Wed AM & 6328 & 13407 & 633 & 1341 & 348 & 737 & 104 & 221 \\
\hline & Wed PM & 6439 & 13641 & 644 & 1364 & 348 & 737 & 104 & 221 \\
\hline & Thurs AM & 6477 & 13722 & 648 & 1372 & 378 & 800 & 113 & 240 \\
\hline & Thurs PM & 6602 & 13987 & 660 & 1399 & 355 & 753 & 107 & 226 \\
\hline \multirow[t]{4}{*}{ ARFW02(01) } & Wed AM & 5155 & 10922 & 516 & 1092 & 4220 & 8941 & 1266 & 2682 \\
\hline & Wed PM & 4946 & 10478 & 495 & 1048 & 4159 & 8810 & 1248 & 2643 \\
\hline & Thurs AM & & & & & & & & \\
\hline & Thurs PM & 4946 & 10478 & 495 & 1048 & 4183 & 8862 & 1255 & 2659 \\
\hline \multirow[t]{4}{*}{ ARFW02(02) } & Wed AM & 6544 & 13865 & 654 & 1386 & & & & \\
\hline & Wed PM & 6300 & 13347 & 630 & 1335 & 5013 & 10620 & 1504 & 3186 \\
\hline & Thurs AM & & & & & & & & \\
\hline & Thurs PM & 6394 & 13546 & 639 & 1355 & 5221 & 11062 & 1566 & 3319 \\
\hline \multirow{4}{*}{ ARFW03(01) } & Wed AM & 3753 & 7951 & 375 & 795 & 158 & 334 & 47 & 100 \\
\hline & Wed PM & 4073 & 8629 & 407 & 863 & 100 & 211 & 30 & 63 \\
\hline & Thurs AM & 3961 & 8392 & 396 & 839 & 108 & 229 & 32 & 69 \\
\hline & Thurs PM & 3945 & 8358 & 395 & 836 & 108 & 229 & 32 & 69 \\
\hline \multirow[t]{4}{*}{ ARFW03(02) } & Wed AM & 2317 & 4908 & 232 & 491 & 254 & 539 & 76 & 162 \\
\hline & Wed PM & 2515 & 5328 & 251 & 533 & 287 & 608 & 86 & 182 \\
\hline & Thurs AM & 2575 & 5455 & 257 & 545 & 328 & 695 & 98 & 209 \\
\hline & Thurs PM & 2503 & 5302 & 250 & 530 & 303 & 643 & 91 & 193 \\
\hline \multirow[t]{4}{*}{\begin{tabular}{|l} 
AZHS02(01) \\
\end{tabular}} & Wed AM & 4579 & 9700 & 458 & 970 & 1670 & 3538 & 985 & 2088 \\
\hline & Wed PM & 5361 & 11359 & 536 & 1136 & 2600 & 5508 & 987 & 2091 \\
\hline & Thurs AM & 4233 & 8967 & 423 & 897 & 1243 & 2633 & 992 & 2101 \\
\hline & Thurs PM & 4397 & 9315 & 440 & 931 & 1628 & 3449 & 940 & 1991 \\
\hline \multirow[t]{4}{*}{\begin{tabular}{|l} 
AZHS02(02) \\
\end{tabular}} & Wed AM & 2541 & 5383 & 254 & 538 & 1177 & 2494 & 482 & 1020 \\
\hline & Wed PM & 2511 & 5319 & 251 & 532 & 1240 & 2628 & 456 & 967 \\
\hline & Thurs AM & 2041 & 4323 & 204 & 432 & 545 & 1155 & 493 & 1044 \\
\hline & Thurs PM & 2481 & 5256 & 248 & 526 & 692 & 1466 & 591 & 1252 \\
\hline \multirow[t]{4}{*}{\begin{tabular}{|l} 
AZHS04(01) \\
\end{tabular}} & Wed AM & 10463 & 22166 & 1046 & 2217 & 0 & 0 & 3309 & 7010 \\
\hline & Wed PM & 10385 & 22001 & 1038 & 2200 & 0 & $\overline{0}$ & 3424 & 7254 \\
\hline & Thurs AM & 10229 & 21671 & 1023 & 2167 & 1069 & 2265 & 2932 & 6212 \\
\hline & Thurs PM & 9831 & 20827 & 983 & 2083 & 0 & 0 & 3339 & 7073 \\
\hline AZHS04(02) & Wed AM & 698 & 1478 & 182 & 386 & 99 & 209 & 30 & 63 \\
\hline & Wed PM & 707 & 1498 & 182 & 386 & 109 & 231 & 33 & 69 \\
\hline & Thurs AM & 716 & 1516 & 193 & 408 & 78 & 166 & 23 & 50 \\
\hline & Thurs PM & 810 & 1716 & 210 & 446 & 119 & 252 & 36 & 76 \\
\hline AZHW10(01) & Wed AM & 8276 & 17533 & 828 & 1753 & 10637 & 22536 & 3191 & 6761 \\
\hline & Wed PM & 7891 & 16717 & 789 & 1672 & 12242 & 25936 & 3673 & 7781 \\
\hline & Thurs AM & 9031 & 19132 & 903 & 1913 & 13458 & 28512 & 4037 & 8554 \\
\hline & Thurs PM & 9179 & 19446 & 918 & 1945 & 13545 & 28696 & 4063 & 8609 \\
\hline AZHW10(02) & Wed AM & 4178 & 8852 & 418 & 885 & & & & \\
\hline & Wed PM & 4297 & 9104 & 430 & 910 & & & & \\
\hline & Thurs AM & 4440 & 9406 & 444 & 941 & & & & \\
\hline & Thurs PM & 4321 & 9154 & 432 & 915 & & & & \\
\hline AZHW11(01) & Wed AM & 14204 & 30093 & 1420 & 3009 & 2705 & 5732 & 3731 & 7904 \\
\hline & Wed PM & 16743 & 35472 & 1674 & 3547 & 4916 & 10415 & 3923 & 8312 \\
\hline & Thurs AM & 16537 & 35036 & 1654 & 3504 & 5531 & 11719 & 3693 & 7824 \\
\hline & Thurs PM & 18116 & 38380 & 1812 & 3838 & 6206 & 13148 & 4006 & 8487 \\
\hline AZHW12(01) & Wed AM & 3647 & 7727 & 365 & 773 & 752 & 1594 & 226 & 478 \\
\hline & Wed PM & 3575 & 7574 & 357 & 757 & 863 & 1828 & 259 & 548 \\
\hline & Thurs AM & 3250 & 6885 & 325 & 689 & 145 & 307 & 43 & 92 \\
\hline & Thurs PM & 3105 & 6579 & 311 & 658 & 110 & 234 & 33 & 70 \\
\hline
\end{tabular}




\begin{tabular}{|c|c|c|c|c|c|c|c|c|c|}
\hline \multirow[b]{2}{*}{ System ID } & \multirow[b]{2}{*}{ Day Period } & \multicolumn{2}{|c|}{ Supply airflow } & \multicolumn{2}{|c|}{$\begin{array}{l}\text { Uncertainty in } \\
\text { supply airflow }\end{array}$} & \multicolumn{2}{|c|}{ Outdoor airflow } & \multicolumn{2}{|c|}{$\begin{array}{c}\begin{array}{c}\text { Uncertainty in outdoor } \\
\text { airflow }\end{array} \\
\end{array}$} \\
\hline & & $\mathrm{L} / \mathrm{s}$ & $\mathrm{cfm}$ & $\mathrm{L} / \mathrm{s}$ & $\mathrm{cfm}$ & $\mathrm{L} / \mathrm{s}$ & $\mathrm{cfm}$ & $\mathrm{L} / \mathrm{s}$ & $\mathrm{cfm}$ \\
\hline \multirow[t]{4}{*}{ AZHW12(02) } & Wed AM & 5236 & 11093 & 524 & 1109 & 1595 & 3380 & 479 & 1014 \\
\hline & Wed PM & 5236 & 11093 & 524 & 1109 & 1595 & 3380 & 479 & 1014 \\
\hline & Thurs AM & 5236 & 11093 & 524 & 1109 & 1617 & 3427 & 485 & 1028 \\
\hline & Thurs PM & 5705 & 12087 & 571 & 1209 & 1738 & 3683 & 522 & 1105 \\
\hline \multirow[t]{4}{*}{\begin{tabular}{|l} 
CAES17(01) \\
\end{tabular}} & Wed AM & 16286 & 34503 & 1629 & 3450 & 3040 & 6441 & 4294 & 9098 \\
\hline & Wed PM & 15564 & 32974 & 1556 & 3297 & 2210 & 4682 & 4298 & 9106 \\
\hline & Thurs AM & 17549 & 37179 & 1755 & 3718 & 9895 & 20963 & 2890 & 6123 \\
\hline & Thurs PM & 16737 & 35459 & 1674 & 3546 & 5120 & 10847 & 3866 & 8191 \\
\hline \multirow[t]{4}{*}{\begin{tabular}{|l|} 
CAEW07(01) \\
\end{tabular}} & Wed AM & 17522 & 37122 & 1752 & 3712 & 5371 & 11380 & 1611 & 3414 \\
\hline & Wed PM & 18569 & 39341 & 1857 & 3934 & 16134 & 34182 & 4840 & 10255 \\
\hline & Thurs AM & 17522 & 37122 & 1752 & 3712 & 13365 & 28315 & 4009 & 8494 \\
\hline & Thurs PM & 17236 & 36516 & 1724 & 3652 & 18092 & 38329 & 5427 & 11499 \\
\hline \multirow[t]{4}{*}{\begin{tabular}{|l} 
CAEW09(01) \\
\end{tabular}} & Wed AM & 11693 & 24773 & 1169 & 2477 & 3704 & 7847 & 1111 & 2354 \\
\hline & Wed PM & 12026 & 25478 & 1203 & 2548 & 3221 & 6824 & 966 & 2047 \\
\hline & Thurs AM & 12317 & 26095 & 1232 & 2609 & 1772 & 3753 & 531 & 1126 \\
\hline & Thurs PM & 11360 & 24067 & 1136 & 2407 & 1691 & 3583 & 507 & 1075 \\
\hline \multirow[t]{4}{*}{\begin{tabular}{|l|l} 
CAJS01(01) \\
\end{tabular}} & Wed AM & 200 & 423 & 20 & 42 & 200 & 423 & 60 & 127 \\
\hline & Wed PM & 200 & 423 & 20 & 42 & 200 & 423 & 60 & 127 \\
\hline & Thurs AM & 155 & 329 & 16 & 33 & 155 & 329 & 47 & 99 \\
\hline & Thurs PM & 200 & 423 & 20 & 42 & 200 & 423 & 60 & 127 \\
\hline \multirow[t]{4}{*}{ CAJS01(02) } & Wed AM & 1336 & 2830 & 134 & 283 & 1336 & 2830 & 401 & 849 \\
\hline & Wed PM & 1315 & 2786 & 131 & 279 & 1315 & 2786 & 394 & 836 \\
\hline & Thurs AM & 1416 & 3000 & 142 & 300 & 1416 & 3000 & 425 & 900 \\
\hline & Thurs PM & 1323 & 2804 & 132 & 280 & 1323 & 2804 & 397 & 841 \\
\hline \multirow[t]{4}{*}{\begin{tabular}{|l|} 
CAJS01(03) \\
\end{tabular}} & Wed AM & 1538 & 3258 & 154 & 326 & 1538 & 3258 & 461 & 977 \\
\hline & Wed PM & 1739 & 3685 & 174 & 368 & 1739 & 3685 & 522 & 1105 \\
\hline & Thurs AM & 1613 & 3418 & 161 & 342 & 1613 & 3418 & 484 & 1025 \\
\hline & Thurs PM & 1647 & 3489 & 165 & 349 & 1647 & 3489 & 494 & 1047 \\
\hline \multirow[t]{4}{*}{ CAJS02(01) } & Wed AM & 14671 & 31081 & 1467 & 3108 & 12430 & 26333 & 3729 & 7900 \\
\hline & Wed PM & 13720 & 29067 & 1372 & 2907 & 12601 & 26696 & 3780 & 8009 \\
\hline & Thurs AM & 14671 & 31081 & 1467 & 3108 & 14368 & 30440 & 4310 & 9132 \\
\hline & Thurs PM & 14331 & 30362 & 1433 & 3036 & 15508 & 32856 & 4653 & 9857 \\
\hline \multirow[t]{4}{*}{ CAJS03(01) } & Wed AM & 40277 & 85330 & 4028 & 8533 & 40277 & 85330 & 12083 & 25599 \\
\hline & Wed PM & 41447 & 87811 & 4145 & 8781 & 41447 & 87811 & 12434 & 26343 \\
\hline & Thurs AM & 42384 & 89795 & 4238 & 8979 & 42384 & 89795 & 12715 & 26938 \\
\hline & Thurs PM & 41631 & 88200 & 4163 & 8820 & 41447 & 87811 & 12434 & 26343 \\
\hline CAJS21(01) & Wed AM & 6088 & 12897 & 609 & 1290 & 1265 & 2679 & 379 & 804 \\
\hline & Wed PM & 4911 & 10405 & 491 & 1040 & 1196 & 2534 & 359 & 760 \\
\hline & Thurs AM & 4558 & 9657 & 456 & 966 & 1647 & 3489 & 494 & 1047 \\
\hline & Thurs PM & 5117 & 10841 & 512 & 1084 & 1470 & 3115 & 441 & 935 \\
\hline CAJS21(02) & Wed AM & 2582 & 5470 & 258 & 547 & 2582 & 5470 & 775 & 1641 \\
\hline & Wed PM & 2849 & 6035 & 285 & 604 & 2849 & 6035 & 855 & 1811 \\
\hline & Thurs AM & 2865 & 6069 & 286 & 607 & 2865 & 6069 & 859 & 1821 \\
\hline & Thurs PM & 2902 & 6149 & 290 & 615 & 2902 & 6149 & 871 & 1845 \\
\hline CAJS222(01) & Wed AM & 4651 & 9854 & 465 & 985 & 391 & 829 & 1360 & 2881 \\
\hline & Wed PM & 5604 & 11873 & 560 & 1187 & 806 & 1708 & 1545 & 3272 \\
\hline & Thurs AM & 4494 & 9521 & 449 & 952 & 929 & 1968 & 1160 & 2458 \\
\hline & Thurs PM & 5567 & 11793 & 557 & 1179 & 1172 & 2483 & 1431 & 3032 \\
\hline CAJS23(01) & Wed AM & 11349 & 24044 & 1135 & 2404 & 837 & 1773 & 251 & 532 \\
\hline & Wed PM & 10010 & 21206 & 1001 & 2121 & 1016 & 2153 & 305 & 646 \\
\hline & Thurs AM & 11238 & 23808 & 1124 & 2381 & 967 & 2048 & 290 & 614 \\
\hline & Thurs PM & 11535 & 24439 & 1154 & 2444 & 1098 & 2326 & 329 & 698 \\
\hline CAJW18(01) & Wed AM & 10464 & 22170 & 1046 & 2217 & 845 & 1791 & 254 & 537 \\
\hline & Wed PM & 10922 & 23140 & 1092 & 2314 & 832 & 1763 & 250 & 529 \\
\hline & Thurs AM & 10709 & 22687 & 1071 & 2269 & 938 & 1986 & 281 & 596 \\
\hline & Thurs PM & 12081 & 25596 & 1208 & 2560 & 938 & 1986 & 281 & 596 \\
\hline
\end{tabular}




\begin{tabular}{|c|c|c|c|c|c|c|c|c|c|}
\hline \multirow[b]{2}{*}{ System ID } & \multirow[b]{2}{*}{ Day Period } & \multicolumn{2}{|c|}{ Supply airflow } & \multicolumn{2}{|c|}{$\begin{array}{r}\text { Uncertainty in } \\
\text { supply airflow }\end{array}$} & \multicolumn{2}{|c|}{ Outdoor airflow } & \multicolumn{2}{|c|}{$\begin{array}{c}\text { Uncertainty in outdoor } \\
\text { airflow }\end{array}$} \\
\hline & & $\mathrm{L} / \mathrm{s}$ & $\mathrm{cfm}$ & $\mathrm{L} / \mathrm{s}$ & $\mathrm{cfm}$ & $\mathrm{L} / \mathrm{s}$ & $\mathrm{cfm}$ & $\mathrm{L} / \mathrm{s}$ & $\mathrm{cfm}$ \\
\hline \multirow[t]{4}{*}{ CAJW19(01) } & Wed AM & 17769 & 37645 & 1777 & 3764 & 8828 & 18703 & 3217 & 6816 \\
\hline & Wed PM & 17430 & 36926 & 1743 & 3693 & 7045 & 14925 & 3570 & 7563 \\
\hline & Thurs AM & 17769 & 37645 & 1777 & 3764 & 8753 & 18543 & 3236 & 6856 \\
\hline & Thurs PM & 16887 & 35777 & 1689 & 3578 & 5530 & 11715 & 3803 & 8056 \\
\hline \multirow[t]{4}{*}{ CAJW20(01) } & Wed AM & 33151 & 70234 & 3315 & 7023 & 39935 & 84606 & 11980 & 25382 \\
\hline & Wed PM & 36439 & 77200 & 3644 & 7720 & 41671 & 88284 & 12501 & 26485 \\
\hline & Thurs AM & 32055 & 67913 & 3206 & 6791 & 36462 & 77249 & 10939 & 23175 \\
\hline & Thurs PM & 32877 & 69654 & 3288 & 6965 & 36936 & 78252 & 11081 & 23476 \\
\hline \multirow[t]{6}{*}{\begin{tabular}{|l} 
CAJW24(01) \\
\end{tabular}} & Tues AM & 19105 & 40475 & 1910 & 4048 & 13205 & 27975 & 3961 & 8393 \\
\hline & Tues PM & 20500 & 43432 & 2050 & 4343 & 741 & 1570 & 222 & 471 \\
\hline & Wed AM & 19105 & 40475 & 1910 & 4048 & 13205 & 27975 & 3961 & 8393 \\
\hline & Wed PM & 21788 & 46160 & 2179 & 4616 & 729 & 1545 & 219 & 463 \\
\hline & Thurs AM & 23076 & 48889 & 2308 & 4889 & 16164 & 34245 & 4849 & 10274 \\
\hline & Thurs PM & 23183 & 49116 & 2318 & 4912 & 20547 & 43530 & 6164 & 13059 \\
\hline \multirow[t]{4}{*}{\begin{tabular}{|l|} 
CAJW25(01) \\
\end{tabular}} & Wed AM & 17130 & 36292 & 1713 & 3629 & 9230 & 19555 & 2769 & 5867 \\
\hline & Wed PM & 18047 & 38233 & 1805 & 3823 & 17256 & 36560 & 5177 & 10968 \\
\hline & Thurs AM & 15964 & 33822 & 1596 & 3382 & 11337 & 24019 & 3401 & 7206 \\
\hline & Thurs PM & 17738 & 37580 & 1774 & 3758 & 18159 & 38473 & 5448 & 11542 \\
\hline \multirow{4}{*}{\begin{tabular}{|l|} 
CAJW26(01) \\
\end{tabular}} & Wed AM & 29773 & 63078 & 2977 & 6308 & 33826 & 71665 & 10148 & 21499 \\
\hline & Wed PM & 33495 & 70962 & 3349 & 7096 & 37230 & 78875 & 11169 & 23662 \\
\hline & Thurs AM & 31205 & 66110 & 3120 & 6611 & 33311 & 70572 & 9993 & 21172 \\
\hline & Thurs PM & 32779 & 69446 & 3278 & 6945 & 30939 & 65547 & 9282 & 19664 \\
\hline \multirow[t]{4}{*}{ COAS02(01) } & Wed AM & 11323 & 23988 & 3163 & 6701 & 810 & 1717 & 243 & 515 \\
\hline & Wed PM & 10049 & 21290 & 2710 & 5742 & 1080 & 2289 & 324 & 687 \\
\hline & Thurs AM & 11012 & 23330 & 3021 & 6401 & 990 & 2098 & 297 & 629 \\
\hline & Thurs PM & 12065 & 25562 & 3188 & 6754 & 1553 & 3290 & 466 & 987 \\
\hline \multirow[t]{4}{*}{ COAS04(01) } & Wed AM & 34210 & 72477 & 3421 & 7248 & 780 & 1652 & 10596 & 22450 \\
\hline & Wed PM & 34890 & 73918 & 3489 & 7392 & 2278 & 4827 & 10387 & 22006 \\
\hline & Thurs AM & 33529 & 71036 & 3353 & 7104 & 153 & 324 & 10559 & 22371 \\
\hline & Thurs PM & 34330 & 72731 & 3433 & 7273 & 0 & 0 & 11020 & 23348 \\
\hline \multirow[t]{4}{*}{ COAS06(01) } & Wed AM & 3837 & 8130 & 384 & 813 & 927 & 1963 & 278 & 589 \\
\hline & Wed PM & 4818 & 10206 & 482 & 1021 & 999 & 2116 & 300 & 635 \\
\hline & Thurs AM & 6446 & 13657 & 645 & 1366 & 1074 & 2275 & 322 & 683 \\
\hline & Thurs PM & 5066 & 10733 & 507 & 1073 & 887 & 1878 & 266 & 564 \\
\hline FLDW07(02) & Wed AM & 7499 & 15888 & 1979 & 4192 & 977 & 2069 & 293 & 621 \\
\hline & Wed PM & 6766 & 14334 & 1755 & 3719 & 1002 & 2122 & 300 & 637 \\
\hline & Thurs AM & 6340 & 13431 & 1634 & 3461 & 983 & 2083 & 295 & 625 \\
\hline & Thurs PM & 6911 & 14643 & 1789 & 3791 & 1039 & 2201 & 312 & 660 \\
\hline FLDW08(01) & Wed AM & 6982 & 14793 & 698 & 1479 & 1307 & 2769 & 392 & 831 \\
\hline & Wed PM & 7647 & 16200 & 765 & 1620 & 871 & 1846 & 261 & 554 \\
\hline & Thurs AM & 7090 & 15020 & 709 & 1502 & 871 & 1846 & 261 & 554 \\
\hline & Thurs PM & 7116 & 15075 & 712 & 1508 & 4773 & 10112 & 1432 & 3034 \\
\hline FLDW10(01) & Wed AM & 3702 & 7844 & 370 & 784 & 285 & 603 & 85 & 181 \\
\hline & Wed PM & 3721 & 7883 & 372 & 788 & 324 & 686 & 97 & 206 \\
\hline & Thurs AM & 3783 & 8015 & 378 & 801 & 356 & 755 & 107 & 226 \\
\hline & Thurs PM & 3417 & 7240 & 342 & 724 & 228 & 482 & 68 & 145 \\
\hline FLGS01(01) & Thurs AM & 4769 & 10103 & 477 & 1010 & 931 & 1973 & 279 & 592 \\
\hline & Thurs PM & 5276 & 11178 & 528 & 1118 & 978 & 2072 & 293 & 622 \\
\hline & Fri AM & 4615 & 9778 & 462 & 978 & 905 & 1917 & 272 & 575 \\
\hline & Fri PM & 5005 & 10603 & 500 & 1060 & 991 & 2099 & 297 & 630 \\
\hline FLGS04(01) & Wed AM & 7019 & 14870 & 702 & 1487 & 246 & 522 & 74 & 157 \\
\hline & Wed PM & 7372 & 15618 & 737 & 1562 & 273 & 579 & 82 & 174 \\
\hline & Thurs AM & 7215 & 15285 & 721 & 1529 & 242 & 513 & 73 & 154 \\
\hline & Thurs PM & 7215 & 15285 & 721 & 1529 & 220 & 466 & 66 & 140 \\
\hline \begin{tabular}{|l|} 
FLGS04(02) \\
\end{tabular} & Wed AM & 9411 & 19937 & 941 & 1994 & 395 & 837 & 118 & 251 \\
\hline & Wed PM & 9469 & 20062 & 947 & 2006 & 381 & 807 & 114 & 242 \\
\hline & Thurs AM & 9607 & 20353 & 961 & 2035 & 398 & 843 & 119 & 253 \\
\hline & Thurs PM & 10058 & 21308 & 1006 & 2131 & 413 & 875 & 124 & 263 \\
\hline
\end{tabular}




\begin{tabular}{|c|c|c|c|c|c|c|c|c|c|}
\hline \multirow[b]{2}{*}{ System ID } & \multirow[b]{2}{*}{ Day Period } & \multicolumn{2}{|c|}{ Supply airflow } & \multicolumn{2}{|c|}{$\begin{array}{l}\text { Uncertainty in } \\
\text { supply airflow }\end{array}$} & \multicolumn{2}{|c|}{ Outdoor airflow } & \multicolumn{2}{|c|}{$\begin{array}{c}\begin{array}{c}\text { Uncertainty in outdoor } \\
\text { airflow }\end{array} \\
\end{array}$} \\
\hline & & $\mathrm{L} / \mathrm{s}$ & $\mathrm{cfm}$ & $\mathrm{L} / \mathrm{s}$ & $\mathrm{cfm}$ & $\mathrm{L} / \mathrm{s}$ & $\mathrm{cfm}$ & $\mathrm{L} / \mathrm{s}$ & $\mathrm{cfm}$ \\
\hline \multirow[t]{4}{*}{\begin{tabular}{|l|} 
FLGS11(01) \\
\end{tabular}} & Wed AM & 2684 & 5686 & 268 & 569 & 433 & 917 & 130 & 275 \\
\hline & Wed PM & 4318 & 9149 & 432 & 915 & 449 & 950 & 135 & 285 \\
\hline & Thurs AM & 2288 & 4848 & 229 & 485 & 433 & 917 & 130 & 275 \\
\hline & Thurs PM & 4542 & 9623 & 454 & 962 & 399 & 846 & 120 & 254 \\
\hline \multirow[t]{4}{*}{\begin{tabular}{|l|} 
FLGS11(02) \\
\end{tabular}} & Wed AM & 3699 & 7837 & 370 & 784 & 532 & 1127 & 160 & 338 \\
\hline & Wed PM & 4594 & 9732 & 459 & 973 & 508 & 1077 & 153 & 323 \\
\hline & Thurs AM & 2976 & 6306 & 298 & 631 & 482 & 1022 & 145 & 307 \\
\hline & Thurs PM & 4250 & 9003 & 425 & 900 & 472 & 1000 & 142 & 300 \\
\hline \multirow[t]{4}{*}{ FLGS12(01) } & Wed AM & 10029 & 21246 & 2564 & 5431 & 1643 & 3480 & 493 & 1044 \\
\hline & Wed PM & 9658 & 20462 & 2452 & 5194 & 1655 & 3507 & 497 & 1052 \\
\hline & Thurs AM & 8985 & 19036 & 2252 & 4772 & 1664 & 3525 & 499 & 1057 \\
\hline & Thurs PM & 8774 & 18589 & 2219 & 4702 & 1538 & 3258 & 461 & 977 \\
\hline \multirow[t]{4}{*}{ GADS01(01) } & Wed AM & 5469 & 11587 & 1185 & 2511 & 2165 & 4588 & 650 & 1376 \\
\hline & Wed PM & 5890 & 12480 & 1327 & 2811 & 1895 & 4014 & 568 & 1204 \\
\hline & Thurs AM & 5522 & 11700 & 1187 & 2514 & 2313 & 4900 & 694 & 1470 \\
\hline & Thurs PM & 5669 & 12010 & 1238 & 2622 & 2145 & 4544 & 643 & 1363 \\
\hline \multirow[t]{4}{*}{ GADS02(01) } & Wed AM & 5291 & 11210 & 529 & 1121 & 855 & 1811 & 256 & 543 \\
\hline & Wed PM & 6143 & 13014 & 614 & 1301 & 978 & 2072 & 293 & 622 \\
\hline & Thurs AM & 5017 & 10630 & 502 & 1063 & 1101 & 2333 & 330 & 700 \\
\hline & Thurs PM & 6105 & 12933 & 610 & 1293 & 989 & 2096 & 297 & 629 \\
\hline \multirow[t]{4}{*}{\begin{tabular}{|l} 
GADS02(02) \\
\end{tabular}} & Wed AM & 5017 & 10630 & 502 & 1063 & 1269 & 2688 & 381 & 806 \\
\hline & Wed PM & 5717 & 12112 & 572 & 1211 & 1118 & 2368 & 335 & 711 \\
\hline & Thurs AM & 5253 & 11129 & 525 & 1113 & 1090 & 2310 & 327 & 693 \\
\hline & Thurs PM & 6409 & 13577 & 641 & 1358 & 1180 & 2499 & 354 & 750 \\
\hline \multirow[t]{4}{*}{\begin{tabular}{|l|} 
GADS03(01) \\
\end{tabular}} & Wed AM & 11988 & 25399 & 1199 & 2540 & 956 & 2026 & 287 & 608 \\
\hline & Wed PM & 11462 & 24283 & 1146 & 2428 & 973 & 2061 & 292 & 618 \\
\hline & Thurs AM & 11415 & 24183 & 1141 & 2418 & 973 & 2061 & 292 & 618 \\
\hline & Thurs PM & 11274 & 23885 & 1127 & 2388 & 978 & 2072 & 293 & 622 \\
\hline ILBS01(01) & Wed AM & 4889 & 10359 & 489 & 1036 & & & & \\
\hline & Wed PM & 4428 & 9381 & 443 & 938 & & & & \\
\hline & Thurs AM & 4161 & 8816 & 416 & 882 & & & & \\
\hline & Thurs PM & 4792 & 10152 & 479 & 1015 & & & & \\
\hline ILBS01(02) & Wed AM & 4460 & 9450 & 446 & 945 & & & & \\
\hline & Wed PM & 4889 & 10359 & 489 & 1036 & & & & \\
\hline & Thurs AM & 4688 & 9932 & 469 & 993 & & & & \\
\hline & Thurs PM & 4720 & 10001 & 472 & 1000 & & & & \\
\hline ILBS02(01) & Wed AM & 7212 & 15280 & 721 & 1528 & 598 & 1267 & 179 & 380 \\
\hline & Wed PM & 7488 & 15864 & 749 & 1586 & 549 & 1163 & 165 & 349 \\
\hline & Thurs AM & 7015 & 14862 & 702 & 1486 & 476 & 1008 & 143 & 302 \\
\hline & Thurs PM & 7173 & 15196 & 717 & 1520 & 543 & 1151 & 163 & 345 \\
\hline ILBS03(01) & Thurs AM & 16385 & 34712 & 1638 & 3471 & 7661 & 16231 & 3088 & 6541 \\
\hline & Thurs PM & 15682 & 33225 & 1568 & 3322 & 6606 & 13995 & 3142 & 6657 \\
\hline & Wed AM & 16229 & 34382 & 1623 & 3438 & 5875 & 12446 & 3505 & 7425 \\
\hline & Wed PM & 16931 & 35870 & 1693 & 3587 & 6027 & 12768 & 3683 & 7804 \\
\hline LAGW04(01) & Wed AM & 9213 & 19518 & 921 & 1952 & 570 & 1207 & 171 & 362 \\
\hline & Wed PM & 9735 & 20624 & 973 & 2062 & 439 & 929 & 132 & 279 \\
\hline & Thurs AM & 8967 & 18997 & 897 & 1900 & 549 & 1163 & 165 & 349 \\
\hline & Thurs PM & 9827 & 20819 & 983 & 2082 & 533 & 1129 & 160 & 339 \\
\hline LAGW04(02) & Wed AM & 10687 & 22641 & 1069 & 2264 & 776 & 1644 & 233 & 493 \\
\hline & Wed PM & 10594 & 22446 & 1059 & 2245 & 821 & 1739 & 246 & 522 \\
\hline & Thurs AM & 10287 & 21795 & 1029 & 2179 & 837 & 1773 & 251 & 532 \\
\hline & Thurs PM & 10533 & 22315 & 1053 & 2232 & 792 & 1678 & 238 & 504 \\
\hline LAGW05(01) & Wed AM & 9409 & 19934 & 941 & 1993 & 2726 & 5775 & 818 & 1732 \\
\hline & Wed PM & 9075 & 19226 & 907 & 1923 & 3054 & 6471 & 916 & 1941 \\
\hline & Thurs AM & 9203 & 19498 & 920 & 1950 & 2868 & 6077 & 860 & 1823 \\
\hline & Thurs PM & 8972 & 19008 & 897 & 1901 & 3023 & 6405 & 907 & 1922 \\
\hline LAGW05(02) & Wed AM & 4926 & 10437 & 493 & 1044 & & & & \\
\hline & Wed PM & 4876 & 10331 & 488 & 1033 & & & & \\
\hline & Thurs AM & 5026 & 10649 & 503 & 1065 & & & & \\
\hline & Thurs PM & 4939 & 10464 & 494 & 1046 & & & & \\
\hline
\end{tabular}




\begin{tabular}{|c|c|c|c|c|c|c|c|c|c|}
\hline \multirow[b]{2}{*}{ System ID } & \multirow[b]{2}{*}{ Day Period } & \multicolumn{2}{|c|}{ Supply airflow } & \multicolumn{2}{|c|}{$\begin{array}{l}\text { Uncertainty in } \\
\text { supply airflow }\end{array}$} & \multicolumn{2}{|c|}{ Outdoor airflow } & \multicolumn{2}{|c|}{$\begin{array}{c}\begin{array}{c}\text { Uncertainty in outdoor } \\
\text { airflow }\end{array} \\
\end{array}$} \\
\hline & & $\mathrm{L} / \mathrm{s}$ & $\mathrm{cfm}$ & $\mathrm{L} / \mathrm{s}$ & $\mathrm{cfm}$ & $\mathrm{L} / \mathrm{s}$ & $\mathrm{cfm}$ & $\mathrm{L} / \mathrm{s}$ & $\mathrm{cfm}$ \\
\hline \multirow[t]{4}{*}{ LAGW06(01) } & Wed AM & 9962 & 21106 & 996 & 2111 & 1259 & 2668 & 378 & 800 \\
\hline & Wed PM & 10012 & 21211 & 1001 & 2121 & 1220 & 2584 & 366 & 775 \\
\hline & Thurs AM & 9933 & 21043 & 993 & 2104 & 1216 & 2575 & 365 & 773 \\
\hline & Thurs PM & 9992 & 21169 & 999 & 2117 & 1232 & 2609 & 369 & 783 \\
\hline \multirow[t]{4}{*}{ LAGW06(02) } & Wed AM & & & & & 141 & 298 & 42 & 90 \\
\hline & Wed PM & & & & & & & & \\
\hline & Thurs AM & & & & & & & & \\
\hline & Thurs PM & & & & & & & & \\
\hline \multirow[t]{4}{*}{ MABW05(01) } & Wed AM & 4182 & 8860 & 418 & 886 & 415 & 880 & 1205 & 2553 \\
\hline & Wed PM & 6951 & 14727 & 695 & 1473 & 1938 & 4107 & 1657 & 3510 \\
\hline & Thurs AM & 6556 & 13889 & 656 & 1389 & 1288 & 2728 & 1711 & 3625 \\
\hline & Thurs PM & 6838 & 14488 & 684 & 1449 & 1740 & 3687 & 1675 & 3549 \\
\hline \multirow[t]{4}{*}{ MABW05(02) } & Wed AM & 6104 & 12931 & 610 & 1293 & 637 & 1350 & 1750 & 3707 \\
\hline & Wed PM & 5991 & 12692 & 599 & 1269 & 0 & 0 & 2028 & 4296 \\
\hline & Thurs AM & 6443 & 13650 & 644 & 1365 & 325 & 689 & 1945 & 4121 \\
\hline & Thurs PM & 6725 & 14248 & 673 & 1425 & 41 & 87 & 2115 & 4481 \\
\hline \multirow[t]{4}{*}{ MABW06(01) } & Wed AM & 2112 & 4474 & 211 & 447 & 1965 & 4163 & 589 & 1249 \\
\hline & Wed PM & 2085 & 4417 & 208 & 442 & 2013 & 4265 & 604 & 1279 \\
\hline & Thurs AM & 1783 & 3776 & 178 & 378 & 1723 & 3651 & 517 & 1095 \\
\hline & Thurs PM & 1728 & 3662 & 173 & 366 & 1675 & 3548 & 502 & 1065 \\
\hline \multirow[t]{4}{*}{ MABW08(01) } & Wed AM & 12910 & 27352 & 1291 & 2735 & 8083 & 17124 & 1940 & 4110 \\
\hline & Wed PM & 13508 & 28619 & 1351 & 2862 & 9097 & 19273 & 1891 & 4006 \\
\hline & Thurs AM & 12597 & 26687 & 1260 & 2669 & 6698 & 14191 & 2172 & 4602 \\
\hline & Thurs PM & 12910 & 27352 & 1291 & 2735 & 7557 & 16011 & 2061 & 4365 \\
\hline \multirow[t]{4}{*}{\begin{tabular}{|l|l} 
MABW08(02) \\
\end{tabular}} & Wed AM & 12379 & 26225 & 3588 & 7602 & 11952 & 25322 & 3586 & 7597 \\
\hline & Wed PM & 11883 & 25176 & 3431 & 7269 & 11427 & 24210 & 3428 & 7263 \\
\hline & Thurs AM & 11537 & 24443 & 3330 & 7055 & 11091 & 23498 & 3327 & 7049 \\
\hline & Thurs PM & 11686 & 24758 & 3332 & 7059 & 11091 & 23498 & 3327 & 7049 \\
\hline \multirow[t]{4}{*}{ MDDS01(01) } & Wed AM & 21258 & 45037 & 2126 & 4504 & 2408 & 5101 & 6041 & 12799 \\
\hline & Wed PM & 22707 & 48108 & 2271 & 4811 & 1439 & 3048 & 6773 & 14349 \\
\hline & Thurs AM & 20292 & 42990 & 2029 & 4299 & 0 & 0 & 7794 & 16512 \\
\hline & Thurs PM & 19889 & 42137 & 1989 & 4214 & 0 & 0 & 6884 & 14585 \\
\hline \multirow[t]{4}{*}{ MDDS03(01) } & Wed AM & 1329 & 2815 & 133 & 282 & 209 & 442 & 63 & 133 \\
\hline & Wed PM & 1332 & 2823 & 133 & 282 & 176 & 372 & 53 & 112 \\
\hline & Thurs AM & 1340 & 2838 & 134 & 284 & 191 & 404 & 57 & 121 \\
\hline & Thurs PM & 1332 & 2823 & 133 & 282 & 181 & 383 & 54 & 115 \\
\hline MDDS03(02) & Wed AM & 2129 & 4511 & 213 & 451 & 68 & 145 & 21 & 43 \\
\hline & Wed PM & 1928 & 4084 & 193 & 408 & 31 & 65 & 9 & 19 \\
\hline & Thurs AM & 2047 & 4336 & 205 & 434 & 65 & 137 & 19 & 41 \\
\hline & Thurs PM & 1994 & 4224 & 199 & 422 & 64 & 135 & 19 & 41 \\
\hline MDDS04(01) & Wed AM & 2558 & 5420 & 256 & 542 & 293 & 620 & 726 & 1539 \\
\hline & Wed PM & 2531 & 5362 & 253 & 536 & 284 & 601 & 720 & 1525 \\
\hline & Thurs AM & 2545 & 5391 & 254 & 539 & 260 & 550 & 731 & 1549 \\
\hline & Thurs PM & 2434 & 5157 & 243 & 516 & 206 & 437 & 711 & 1507 \\
\hline MDDS04(02) & Wed AM & 2142 & 4538 & 214 & 454 & 572 & 1212 & 517 & 1096 \\
\hline & Wed PM & 1924 & 4077 & 192 & 408 & 456 & 966 & 481 & 1019 \\
\hline & Thurs AM & 1993 & 4223 & 199 & 422 & 446 & 945 & 505 & 1070 \\
\hline & Thurs PM & 1940 & 4111 & 194 & 411 & 505 & 1070 & 472 & 1000 \\
\hline MIBW01(01) & Wed AM & 2857 & 6053 & 286 & 605 & 1698 & 3598 & 450 & 953 \\
\hline & Wed PM & 2990 & 6336 & 299 & 634 & 1949 & 4128 & 433 & 916 \\
\hline & Thurs AM & 2857 & 6053 & 286 & 605 & 1599 & 3387 & 473 & 1003 \\
\hline & Thurs PM & 3009 & 6375 & 301 & 637 & 1531 & 3243 & 536 & 1135 \\
\hline MIBW01(02) & Wed AM & 2295 & 4861 & 229 & 486 & 202 & 428 & 668 & 1416 \\
\hline & Wed PM & 2765 & 5857 & 276 & 586 & 1052 & 2230 & 583 & 1236 \\
\hline & Thurs AM & 2313 & 4901 & 231 & 490 & & & & \\
\hline & Thurs PM & 2443 & 5175 & 244 & 518 & & & & \\
\hline
\end{tabular}




\begin{tabular}{|c|c|c|c|c|c|c|c|c|c|}
\hline \multirow[b]{2}{*}{ System ID } & \multirow[b]{2}{*}{ Day Period } & \multicolumn{2}{|c|}{ Supply airflow } & \multicolumn{2}{|c|}{$\begin{array}{r}\text { Uncertainty in } \\
\text { supply airflow }\end{array}$} & \multicolumn{2}{|c|}{ Outdoor airflow } & \multicolumn{2}{|c|}{$\begin{array}{c}\begin{array}{c}\text { Uncertainty in outdoor } \\
\text { airflow }\end{array} \\
\end{array}$} \\
\hline & & $\mathrm{L} / \mathrm{s}$ & $\mathrm{cfm}$ & $\mathrm{L} / \mathrm{s}$ & $\mathrm{cfm}$ & $\mathrm{L} / \mathrm{s}$ & $\mathrm{cfm}$ & $\mathrm{L} / \mathrm{s}$ & $\mathrm{cfm}$ \\
\hline \multirow[t]{4}{*}{ MIBW03(01) } & Wed AM & 16081 & 34070 & 1608 & 3407 & 4577 & 9696 & 3808 & 8067 \\
\hline & Wed PM & 15998 & 33894 & 1600 & 3389 & 3486 & 7385 & 4080 & 8645 \\
\hline & Thurs AM & 16367 & 34675 & 1637 & 3468 & 3999 & 8472 & 4055 & 8592 \\
\hline & Thurs PM & 13975 & 29606 & 1397 & 2961 & 4711 & 9981 & 3111 & 6590 \\
\hline \multirow[t]{4}{*}{ MIBW04(01) } & Wed AM & 4319 & 9151 & 432 & 915 & 1317 & 2790 & 999 & 2116 \\
\hline & Wed PM & 4307 & 9124 & 431 & 912 & 1606 & 3403 & 917 & 1944 \\
\hline & Thurs AM & 5031 & 10658 & 503 & 1066 & 1264 & 2677 & 1237 & 2621 \\
\hline & Thurs PM & 5107 & 10819 & 511 & 1082 & 1651 & 3499 & 1156 & 2448 \\
\hline \multirow[t]{4}{*}{ MIBW04(02) } & Wed AM & 5624 & 11915 & 562 & 1191 & 2169 & 4594 & 1179 & 2499 \\
\hline & Wed PM & 5423 & 11489 & 542 & 1149 & 1883 & 3989 & 1193 & 2527 \\
\hline & Thurs AM & 5122 & 10851 & 512 & 1085 & 1327 & 2810 & 1248 & 2645 \\
\hline & Thurs PM & 5875 & 12447 & 588 & 1245 & 2401 & 5087 & 1196 & 2535 \\
\hline \multirow[t]{4}{*}{\begin{tabular}{|l} 
MNBW01(01) \\
\end{tabular}} & Wed AM & 4257 & 9019 & 426 & 902 & 1104 & 2340 & 331 & 702 \\
\hline & Wed PM & 4816 & 10203 & 482 & 1020 & 1113 & 2359 & 334 & 708 \\
\hline & Thurs AM & 4284 & 9076 & 428 & 908 & 1072 & 2272 & 322 & 682 \\
\hline & Thurs PM & 4710 & 9978 & 471 & 998 & 1165 & 2469 & 350 & 741 \\
\hline \multirow[t]{4}{*}{ MNBW02(01) } & Wed AM & 5487 & 11625 & 549 & 1162 & 1526 & 3232 & 458 & 970 \\
\hline & Wed PM & 5869 & 12434 & 587 & 1243 & 1730 & 3666 & 519 & 1100 \\
\hline & Thurs AM & 4342 & 9199 & 434 & 920 & 1805 & 3823 & 541 & 1147 \\
\hline & Thurs PM & 5344 & 11322 & 534 & 1132 & 2233 & 4730 & 670 & 1419 \\
\hline \multirow[t]{4}{*}{ MNBW02(02) } & Wed AM & 8190 & 17352 & 819 & 1735 & 2419 & 5124 & 726 & 1537 \\
\hline & Wed PM & 10586 & 22427 & 1059 & 2243 & 4502 & 9539 & 1351 & 2862 \\
\hline & Thurs AM & 6853 & 14519 & 685 & 1452 & 4279 & 9066 & 1284 & 2720 \\
\hline & Thurs PM & 7689 & 16289 & 769 & 1629 & 3516 & 7450 & 1055 & 2235 \\
\hline \multirow[t]{4}{*}{\begin{tabular}{|l|} 
MNBW04(01) \\
\end{tabular}} & Wed AM & 9340 & 19787 & 934 & 1979 & 6735 & 14269 & 2021 & 4281 \\
\hline & Wed PM & 8931 & 18920 & 893 & 1892 & 7330 & 15530 & 2199 & 4659 \\
\hline & Thurs AM & 10270 & 21758 & 1027 & 2176 & 7256 & 15373 & 2177 & 4612 \\
\hline & Thurs PM & 9042 & 19157 & 904 & 1916 & 7740 & 16398 & 2322 & 4919 \\
\hline \multirow[t]{4}{*}{\begin{tabular}{|l|} 
MOCS01(01) \\
\end{tabular}} & Wed AM & 24167 & 51200 & 2417 & 5120 & & & & \\
\hline & Wed PM & 28638 & 60672 & 2864 & 6067 & & & & \\
\hline & Thurs AM & 25979 & 55040 & 2598 & 5504 & & & & \\
\hline & Thurs PM & 28396 & 60160 & 2840 & 6016 & & & & \\
\hline \multirow[t]{4}{*}{ MOCS05(01) } & Wed AM & 45207 & 95775 & 4521 & 9578 & 14860 & 31482 & 4458 & 9445 \\
\hline & Wed PM & 50117 & 106178 & 5012 & 10618 & 17710 & 37519 & 5313 & 11256 \\
\hline & Thurs AM & 40690 & 86206 & 4069 & 8621 & 8957 & 18975 & 2687 & 5693 \\
\hline & Thurs PM & 39282 & 83222 & 3928 & 8322 & 1018 & 2156 & 305 & 647 \\
\hline NCDW02(01) & Wed AM & 10767 & 22811 & 1077 & 2281 & 10054 & 21300 & 3016 & 6390 \\
\hline & Wed PM & 11227 & 23786 & 1123 & 2379 & 10622 & 22504 & 3187 & 6751 \\
\hline & Thurs AM & 11043 & 23396 & 1104 & 2340 & 5595 & 11854 & 1679 & 3556 \\
\hline & Thurs PM & 11227 & 23786 & 1123 & 2379 & 9311 & 19726 & 2793 & 5918 \\
\hline NCDW02(02) & Wed AM & 11595 & 24566 & 1160 & 2457 & 10054 & 21300 & 3016 & 6390 \\
\hline & Wed PM & 12976 & 27490 & 1298 & 2749 & 10622 & 22504 & 3187 & 6751 \\
\hline & Thurs AM & 12055 & 25541 & 1206 & 2554 & 5595 & 11854 & 1679 & 3556 \\
\hline & Thurs PM & 12239 & 25931 & 1224 & 2593 & 9311 & 19726 & 2793 & 5918 \\
\hline NCDW03(01) & Wed AM & & & & & & & & \\
\hline & Wed PM & & & & & & & & \\
\hline & Thurs AM & & & & & & & & \\
\hline & Thurs PM & & & & & & & & \\
\hline NCDW03(02) & Wed AM & & & & & & & & \\
\hline & Wed PM & & & & & & & & \\
\hline & Thurs AM & & & & & & & & \\
\hline & Thurs PM & & & & & & & & \\
\hline NCDW03(03) & Wed AM & & & & & & & & \\
\hline & Wed PM & & & & & & & & \\
\hline & Thurs AM & & & & & & & & \\
\hline & Thurs PM & 49 & 104 & 12 & 25 & 37 & 79 & 11 & 24 \\
\hline
\end{tabular}




\begin{tabular}{|c|c|c|c|c|c|c|c|c|c|}
\hline \multirow[b]{2}{*}{ System ID } & \multirow[b]{2}{*}{ Day Period } & \multicolumn{2}{|c|}{ Supply airflow } & \multicolumn{2}{|c|}{$\begin{array}{r}\text { Uncertainty in } \\
\text { supply airflow }\end{array}$} & \multicolumn{2}{|c|}{ Outdoor airflow } & \multicolumn{2}{|c|}{$\begin{array}{c}\begin{array}{c}\text { Uncertainty in outdoor } \\
\text { airflow }\end{array} \\
\end{array}$} \\
\hline & & $\mathrm{L} / \mathrm{s}$ & $\mathrm{cfm}$ & $\mathrm{L} / \mathrm{s}$ & $\mathrm{cfm}$ & $\mathrm{L} / \mathrm{s}$ & $\mathrm{cfm}$ & $\mathrm{L} / \mathrm{s}$ & $\mathrm{cfm}$ \\
\hline \multirow[t]{4}{*}{\begin{tabular}{|l|} 
NCDW03(04) \\
\end{tabular}} & Wed AM & 85 & 181 & 22 & 47 & 74 & 156 & 22 & 47 \\
\hline & Wed PM & 83 & 175 & 22 & 46 & 71 & 150 & 21 & 45 \\
\hline & Thurs AM & 88 & 186 & 23 & 49 & 76 & 161 & 23 & 48 \\
\hline & Thurs PM & 61 & 128 & 15 & 32 & 49 & 103 & 15 & 31 \\
\hline \multirow[t]{4}{*}{ NCDW03(05) } & Wed AM & & & & & & & & \\
\hline & Wed PM & & & & & & & & \\
\hline & Thurs AM & & & & & & & & \\
\hline & Thurs PM & & & & & & & & \\
\hline \multirow[t]{4}{*}{ NCDW06(01) } & Wed AM & 6300 & 13348 & 630 & 1335 & 2419 & 5124 & 726 & 1537 \\
\hline & Wed PM & 7078 & 14996 & 708 & 1500 & 4016 & 8508 & 1205 & 2552 \\
\hline & Thurs AM & 5322 & 11276 & 532 & 1128 & 3814 & 8081 & 1144 & 2424 \\
\hline & Thurs PM & 6300 & 13348 & 630 & 1335 & 2326 & 4927 & 698 & 1478 \\
\hline \multirow[t]{4}{*}{ NECW01(01) } & Wed AM & 42102 & 89197 & 4210 & 8920 & 13910 & 29471 & 4173 & 8841 \\
\hline & Wed PM & 40713 & 86254 & 4071 & 8625 & 16197 & 34315 & 4859 & 10295 \\
\hline & Thurs AM & 43810 & 92816 & 4381 & 9282 & 15625 & 33104 & 4688 & 9931 \\
\hline & Thurs PM & 43304 & 91744 & 4330 & 9174 & 25281 & 53560 & 7584 & 16068 \\
\hline \multirow[t]{4}{*}{ NECW02(01) } & Wed AM & 67711 & 143453 & 6771 & 14345 & 53438 & 113213 & 16031 & 33964 \\
\hline & Wed PM & 52310 & 110824 & 5231 & 11082 & 29626 & 62766 & 8888 & 18830 \\
\hline & Thurs AM & 68229 & 144550 & 6823 & 14455 & 51499 & 109107 & 15450 & 32732 \\
\hline & Thurs PM & 66517 & 140922 & 6652 & 14092 & 48731 & 103241 & 14619 & 30972 \\
\hline \multirow[t]{4}{*}{ NECW03(01) } & Wed AM & 27504 & 58269 & 2750 & 5827 & 18860 & 39956 & 5658 & 11987 \\
\hline & Wed PM & 31117 & 65925 & 3112 & 6593 & 20824 & 44118 & 6247 & 13236 \\
\hline & Thurs AM & 32121 & 68052 & 3212 & 6805 & 14980 & 31736 & 4494 & 9521 \\
\hline & Thurs PM & 28307 & 59971 & 2831 & 5997 & 24950 & 52859 & 7485 & 15858 \\
\hline \multirow[t]{4}{*}{ NMES01(01) } & Wed AM & 3517 & 7451 & 746 & 1581 & 1799 & 3811 & 540 & 1143 \\
\hline & Wed PM & 3384 & 7168 & 742 & 1571 & 2132 & 4516 & 640 & 1355 \\
\hline & Thurs AM & 3190 & 6758 & 678 & 1437 & 1699 & 3599 & 510 & 1080 \\
\hline & Thurs PM & 3310 & 7013 & 714 & 1512 & 1954 & 4140 & 586 & 1242 \\
\hline \multirow[t]{4}{*}{\begin{tabular}{|l|} 
NMES01(02) \\
\end{tabular}} & Wed AM & 5609 & 11884 & 1408 & 2983 & 1030 & 2182 & 309 & 655 \\
\hline & Wed PM & 5878 & 12453 & 1490 & 3157 & 1016 & 2152 & 305 & 645 \\
\hline & Thurs AM & 4957 & 10502 & 1298 & 2749 & 687 & 1455 & 206 & 436 \\
\hline & Thurs PM & 5638 & 11944 & 1440 & 3050 & 930 & 1970 & 279 & 591 \\
\hline \multirow[t]{4}{*}{ NMES02(01) } & Wed AM & 6220 & 13177 & 622 & 1318 & 8612 & 18245 & 2584 & 5474 \\
\hline & Wed PM & 6897 & 14612 & 690 & 1461 & 8561 & 18136 & 2568 & 5441 \\
\hline & Thurs AM & 7405 & 15687 & 740 & 1569 & 8021 & 16993 & 2406 & 5098 \\
\hline & Thurs PM & 5966 & 12640 & 597 & 1264 & 9075 & 19226 & 2722 & 5768 \\
\hline NMES03(01) & Wed AM & 3423 & 7251 & 342 & 725 & 248 & 526 & 1012 & 2144 \\
\hline & Wed PM & 3498 & 7410 & 350 & 741 & 466 & 986 & 975 & 2065 \\
\hline & Thurs AM & 3122 & 6614 & 312 & 661 & 319 & 677 & 897 & 1900 \\
\hline & Thurs PM & 3046 & 6454 & 305 & 645 & 58 & 123 & 947 & 2006 \\
\hline NMES03(02) & Wed AM & 4992 & 10577 & 499 & 1058 & 548 & 1161 & 1424 & 3016 \\
\hline & Wed PM & 6468 & 13704 & 647 & 1370 & 959 & 2033 & 1775 & 3760 \\
\hline & Thurs AM & 5470 & 11589 & 547 & 1159 & 1054 & 2233 & 1433 & 3036 \\
\hline & Thurs PM & 5991 & 12692 & 599 & 1269 & 865 & 1833 & 1650 & 3496 \\
\hline NVAW01(01) & Wed AM & 46440 & 98387 & 4644 & 9839 & 46478 & 98468 & 13943 & 29540 \\
\hline & Wed PM & 48395 & 102530 & 4840 & 10253 & 32571 & 69005 & 9771 & 20702 \\
\hline & Thurs AM & 49699 & 105291 & 4970 & 10529 & 27074 & 57358 & 8122 & 17207 \\
\hline & Thurs PM & 50350 & 106672 & 5035 & 10667 & 13962 & 29580 & 4189 & 8874 \\
\hline NVAW02(01) & Wed AM & 24729 & 52391 & 2473 & 5239 & 23554 & 49902 & 7066 & 14971 \\
\hline & Wed PM & 27597 & 58466 & 2760 & 5847 & 26457 & 56051 & 7937 & 16815 \\
\hline & Thurs AM & 24045 & 50942 & 2405 & 5094 & 23145 & 49035 & 6943 & 14710 \\
\hline & Thurs PM & 27465 & 58187 & 2746 & 5819 & 25638 & 54317 & 7691 & 16295 \\
\hline NVAW03(01) & Wed AM & 5207 & 11033 & 521 & 1103 & 5679 & 12031 & 1704 & 3609 \\
\hline & Wed PM & 5074 & 10751 & 507 & 1075 & 5747 & 12176 & 1724 & 3653 \\
\hline & Thurs AM & 5188 & 10992 & 519 & 1099 & 5702 & 12079 & 1710 & 3624 \\
\hline & Thurs PM & 5207 & 11033 & 521 & 1103 & 5724 & 12128 & 1717 & 3638 \\
\hline
\end{tabular}




\begin{tabular}{|c|c|c|c|c|c|c|c|c|c|}
\hline \multirow[b]{2}{*}{ System ID } & \multirow[b]{2}{*}{ Day Period } & \multicolumn{2}{|c|}{ Supply airflow } & \multicolumn{2}{|c|}{$\begin{array}{r}\text { Uncertainty in } \\
\text { supply airflow }\end{array}$} & \multicolumn{2}{|c|}{ Outdoor airflow } & \multicolumn{2}{|c|}{$\begin{array}{c}\text { Uncertainty in outdoor } \\
\text { airflow }\end{array}$} \\
\hline & & $\mathrm{L} / \mathrm{s}$ & $\mathrm{cfm}$ & $\mathrm{L} / \mathrm{s}$ & $\mathrm{cfm}$ & $\mathrm{L} / \mathrm{s}$ & $\mathrm{cfm}$ & $\mathrm{L} / \mathrm{s}$ & $\mathrm{cfm}$ \\
\hline \multirow[t]{4}{*}{ NVAW03(02) } & Wed AM & 3695 & 7829 & 370 & 783 & 1802 & 3818 & 541 & 1146 \\
\hline & Wed PM & 3582 & 7590 & 358 & 759 & 1802 & 3818 & 541 & 1146 \\
\hline & Thurs AM & 3441 & 7291 & 344 & 729 & 1764 & 3737 & 529 & 1121 \\
\hline & Thurs PM & 3653 & 7739 & 365 & 774 & 1818 & 3851 & 545 & 1155 \\
\hline \multirow[t]{4}{*}{ NYBS01(01) } & Wed AM & 31613 & 66976 & 3161 & 6698 & 4645 & 9841 & 8686 & 18402 \\
\hline & Wed PM & 32918 & 69739 & 3292 & 6974 & 3897 & 8256 & 9308 & 19720 \\
\hline & Thurs AM & 31951 & 67692 & 3195 & 6769 & 3478 & 7369 & 9120 & 19322 \\
\hline & Thurs PM & 32612 & 69091 & 3261 & 6909 & 4138 & 8768 & 9143 & 19371 \\
\hline \multirow[t]{4}{*}{ NYBS01(02) } & Wed AM & 16430 & 34808 & 1643 & 3481 & 2423 & 5134 & 727 & 1540 \\
\hline & Wed PM & 17456 & 36982 & 1746 & 3698 & 2594 & 5496 & 778 & 1649 \\
\hline & Thurs AM & 17564 & 37211 & 1756 & 3721 & 2509 & 5315 & 753 & 1594 \\
\hline & Thurs PM & 17411 & 36887 & 1741 & 3689 & 2680 & 5677 & 804 & 1703 \\
\hline \multirow[t]{4}{*}{ NYBS02(01) } & Wed AM & 2861 & 6061 & 286 & 606 & 286 & 605 & 86 & 182 \\
\hline & Wed PM & 2981 & 6315 & 298 & 632 & 286 & 605 & 86 & 182 \\
\hline & Thurs AM & 3201 & 6781 & 320 & 678 & 235 & 498 & 71 & 150 \\
\hline & Thurs PM & 2101 & 4450 & 210 & 445 & 286 & 605 & 86 & 182 \\
\hline \multirow[t]{4}{*}{ NYBS02(02) } & Wed AM & 3901 & 8265 & 390 & 826 & 353 & 748 & 106 & 224 \\
\hline & Wed PM & 3401 & 7205 & 340 & 721 & 429 & 908 & 129 & 272 \\
\hline & Thurs AM & 3221 & 6824 & 322 & 682 & 378 & 801 & 113 & 240 \\
\hline & Thurs PM & 2321 & 4917 & 232 & 492 & 378 & 801 & 113 & 240 \\
\hline \multirow[t]{4}{*}{ NYBS04(01) } & Wed AM & 6706 & 14208 & 671 & 1421 & 91 & 193 & 27 & 58 \\
\hline & Wed PM & 7003 & 14838 & 700 & 1484 & 91 & 193 & 27 & 58 \\
\hline & Thurs AM & 7460 & 15805 & 746 & 1580 & 5717 & 12112 & 1715 & 3633 \\
\hline & Thurs PM & 7334 & 15537 & 733 & 1554 & 84 & 177 & 25 & 53 \\
\hline \multirow[t]{4}{*}{$\begin{array}{l}\text { NYBS04(02) } \\
\end{array}$} & Wed AM & 8252 & 17483 & 825 & 1748 & 306 & 648 & 92 & 195 \\
\hline & Wed PM & 8005 & 16959 & 800 & 1696 & 281 & 594 & 84 & 178 \\
\hline & Thurs AM & 8290 & 17563 & 829 & 1756 & 7559 & 16014 & 2268 & 4804 \\
\hline & Thurs PM & 8402 & 17801 & 840 & 1780 & 298 & 630 & 89 & 189 \\
\hline NYBS05(01) & Wed AM & 5655 & 11981 & 566 & 1198 & 1441 & 3052 & 432 & 916 \\
\hline & Wed PM & 6101 & 12926 & 610 & 1293 & 1454 & 3080 & 436 & 924 \\
\hline & Thurs AM & 5890 & 12478 & 589 & 1248 & 1454 & 3080 & 436 & 924 \\
\hline & Thurs PM & 5936 & 12575 & 594 & 1258 & 1347 & 2854 & 404 & 856 \\
\hline NYBS07(01) & Wed AM & 5071 & 10743 & 1256 & 2660 & 1008 & 2137 & 303 & 641 \\
\hline & Wed PM & 5311 & 11252 & 1315 & 2785 & 1058 & 2242 & 317 & 673 \\
\hline & Thurs AM & 5230 & 11080 & 1288 & 2729 & 1072 & 2272 & 322 & 682 \\
\hline & Thurs PM & 5006 & 10606 & 1238 & 2624 & 1001 & 2122 & 300 & 636 \\
\hline ORIS03(01) & Wed AM & 26408 & 55948 & 3083 & 6533 & 11842 & 25089 & 3553 & 7527 \\
\hline & Wed PM & 30621 & 64874 & 3537 & 7494 & 12767 & 27048 & 3830 & 8115 \\
\hline & Thurs AM & 23088 & 48915 & 2682 & 5683 & 10415 & 22065 & 3124 & 6619 \\
\hline & Thurs PM & 26075 & 55243 & 3024 & 6407 & 12144 & 25728 & 3643 & 7718 \\
\hline ORIS03(03) & Wed AM & & & & & & & & \\
\hline & Wed PM & & & & & & & & \\
\hline & Thurs AM & & & & & & & & \\
\hline & Thurs PM & & & & & & & & \\
\hline ORIS04(01) & Wed AM & & & & & & & & \\
\hline & Wed PM & 6117 & 12959 & 612 & 1296 & & & & \\
\hline & Thurs AM & 8734 & 18504 & 873 & 1850 & & & & \\
\hline & Thurs PM & 8528 & 18068 & 853 & 1807 & & & & \\
\hline PABS03(01) & Wed AM & 15911 & 33709 & 1591 & 3371 & 0 & 0 & 5214 & 11046 \\
\hline & Wed PM & 14736 & 31220 & 1474 & 3122 & 0 & 0 & 5125 & 10857 \\
\hline & Thurs AM & 14997 & 31773 & 1500 & 3177 & 0 & 0 & 5598 & 11860 \\
\hline & Thurs PM & 16288 & 34508 & 1629 & 3451 & 0 & 0 & 5908 & 12516 \\
\hline$\overline{P A B S 04(01)}$ & Wed AM & 11128 & 23577 & 1113 & 2358 & 2195 & 4651 & 659 & 1395 \\
\hline & Wed PM & 10982 & 23267 & 1098 & 2327 & 2121 & 4494 & 636 & 1348 \\
\hline & Thurs AM & 10311 & 21844 & 1031 & 2184 & 2009 & 4257 & 603 & 1277 \\
\hline & Thurs PM & 10610 & 22478 & 1061 & 2248 & 2121 & 4494 & 636 & 1348 \\
\hline PABS04(02) & Wed AM & 8150 & 17267 & 815 & 1727 & 309 & 655 & 93 & 196 \\
\hline & Wed PM & 8070 & 17098 & 807 & 1710 & 309 & 655 & 93 & 196 \\
\hline & Thurs AM & 7682 & 16275 & 768 & 1628 & 268 & 568 & 80 & 170 \\
\hline & Thurs PM & 8130 & 17225 & 813 & 1722 & 288 & 611 & 87 & 183 \\
\hline
\end{tabular}




\begin{tabular}{|c|c|c|c|c|c|c|c|c|c|}
\hline \multirow[b]{2}{*}{ System ID } & \multirow[b]{2}{*}{ Day Period } & \multicolumn{2}{|c|}{ Supply airflow } & \multicolumn{2}{|c|}{$\begin{array}{r}\text { Uncertainty in } \\
\text { supply airflow }\end{array}$} & \multicolumn{2}{|c|}{ Outdoor airflow } & \multicolumn{2}{|c|}{$\begin{array}{c}\begin{array}{c}\text { Uncertainty in outdoor } \\
\text { airflow }\end{array} \\
\end{array}$} \\
\hline & & $\mathrm{L} / \mathrm{s}$ & $\mathrm{cfm}$ & $\mathrm{L} / \mathrm{s}$ & $\mathrm{cfm}$ & $\mathrm{L} / \mathrm{s}$ & $\mathrm{cfm}$ & $\mathrm{L} / \mathrm{s}$ & $\mathrm{cfm}$ \\
\hline \multirow[t]{4}{*}{ SCDW01(01) } & Wed AM & 6063 & 12844 & 606 & 1284 & 1463 & 3100 & 439 & 930 \\
\hline & Wed PM & 5127 & 10863 & 513 & 1086 & 1279 & 2709 & 384 & 813 \\
\hline & Thurs AM & 5634 & 11935 & 563 & 1194 & 1340 & 2839 & 402 & 852 \\
\hline & Thurs PM & 4830 & 10234 & 483 & 1023 & 1063 & 2252 & 319 & 676 \\
\hline \multirow[t]{4}{*}{\begin{tabular}{|l} 
SCDW02(01) \\
\end{tabular}} & Wed AM & 24154 & 51173 & 2415 & 5117 & 4391 & 9302 & 1317 & 2791 \\
\hline & Wed PM & 26087 & 55267 & 2609 & 5527 & 4875 & 10327 & 1462 & 3098 \\
\hline & Thurs AM & 23560 & 49914 & 2356 & 4991 & 4502 & 9539 & 1351 & 2862 \\
\hline & Thurs PM & 24526 & 51961 & 2453 & 5196 & 3795 & 8041 & 1139 & 2412 \\
\hline \multirow[t]{4}{*}{\begin{tabular}{|l|} 
SDBW01(01) \\
\end{tabular}} & Wed AM & 6419 & 13600 & 642 & 1360 & 2930 & 6208 & 879 & 1862 \\
\hline & Wed PM & 6870 & 14555 & 687 & 1455 & 3551 & 7524 & 1065 & 2257 \\
\hline & Thurs AM & 6547 & 13870 & 655 & 1387 & 3425 & 7256 & 1028 & 2177 \\
\hline & Thurs PM & 6776 & 14357 & 678 & 1436 & 3697 & 7832 & 1109 & 2350 \\
\hline \multirow[t]{4}{*}{\begin{tabular}{|l|} 
SDBW02(01) \\
\end{tabular}} & Wed AM & 7185 & 15222 & 718 & 1522 & 3187 & 6752 & 956 & 2026 \\
\hline & Wed PM & 6560 & 13898 & 656 & 1390 & 1923 & 4073 & 577 & 1222 \\
\hline & Thurs AM & 7150 & 15148 & 715 & 1515 & 2026 & 4292 & 608 & 1288 \\
\hline & Thurs PM & 6630 & 14045 & 663 & 1405 & 1561 & 3308 & 468 & 992 \\
\hline \multirow{4}{*}{\begin{tabular}{|l} 
SDBW04(01) \\
\end{tabular}} & Wed AM & 11859 & 25125 & 1186 & 2512 & 2541 & 5383 & 3037 & 6433 \\
\hline & Wed PM & 10063 & 21320 & 1006 & 2132 & 2001 & 4239 & 2620 & 5550 \\
\hline & Thurs AM & 9689 & 20528 & 969 & 2053 & 1891 & 4007 & 2532 & 5365 \\
\hline & Thurs PM & 9615 & 20369 & 961 & 2037 & 2081 & 4408 & 2456 & 5204 \\
\hline \multirow[t]{4}{*}{ TNDS05(01) } & Wed AM & 9596 & 20329 & 960 & 2033 & 9596 & 20329 & 2879 & 6099 \\
\hline & \begin{tabular}{|l|} 
Wed PM \\
\end{tabular} & 10762 & 22800 & 1076 & 2280 & 10762 & 22800 & 3229 & 6840 \\
\hline & Thurs AM & 10232 & 21677 & 1023 & 2168 & 10232 & 21677 & 3070 & 6503 \\
\hline & Thurs PM & 9649 & 20442 & 965 & 2044 & 9649 & 20442 & 2895 & 6133 \\
\hline \multirow[t]{4}{*}{ TNDS05(02) } & Wed AM & 4616 & 9780 & 462 & 978 & 4616 & 9780 & 1385 & 2934 \\
\hline & Wed PM & 4454 & 9436 & 445 & 944 & 4454 & 9436 & 1336 & 2831 \\
\hline & Thurs AM & 4259 & 9022 & 426 & 902 & 4259 & 9022 & 1278 & 2707 \\
\hline & Thurs PM & 4031 & 8540 & 403 & 854 & 4031 & 8540 & 1209 & 2562 \\
\hline \multirow[t]{4}{*}{\begin{tabular}{|l} 
TNDS06(01) \\
\end{tabular}} & Wed AM & 86266 & 182763 & 8627 & 18276 & 18357 & 38892 & 22124 & 46871 \\
\hline & Wed PM & 73705 & 156152 & 7371 & 15615 & 6302 & 13352 & 21522 & 45597 \\
\hline & Thurs AM & 67711 & 143452 & 6771 & 14345 & 8809 & 18663 & 18923 & 40091 \\
\hline & Thurs PM & 69550 & 147348 & 6955 & 14735 & 1539 & 3262 & 21556 & 45668 \\
\hline \multirow[t]{4}{*}{ TNDS07(01) } & Wed AM & 4470 & 9470 & 447 & 947 & 107 & 226 & 32 & 68 \\
\hline & Wed PM & 4318 & 9148 & 432 & 915 & 128 & 271 & 38 & 81 \\
\hline & Thurs AM & 4470 & 9470 & 447 & 947 & 135 & 286 & 40 & 86 \\
\hline & Thurs PM & 4516 & 9567 & 452 & 957 & 717 & 1520 & 215 & 456 \\
\hline TNFS08(01) & Wed AM & 3023 & 6405 & 302 & 641 & 616 & 1305 & 185 & 391 \\
\hline & Wed PM & 3047 & 6456 & 305 & 646 & 745 & 1579 & 224 & 474 \\
\hline & Thurs AM & 3262 & 6910 & 326 & 691 & 745 & 1579 & 224 & 474 \\
\hline & Thurs PM & 3952 & 8373 & 395 & 837 & 713 & 1511 & 214 & 453 \\
\hline TNFS08(02) & Wed AM & 1336 & 2830 & 312 & 662 & 359 & 760 & 108 & 228 \\
\hline & Wed PM & 1352 & 2864 & 328 & 695 & 300 & 636 & 90 & 191 \\
\hline & Thurs AM & 1364 & 2889 & 330 & 699 & 308 & 653 & 92 & 196 \\
\hline & Thurs PM & 1316 & 2788 & 319 & 675 & 296 & 628 & 89 & 188 \\
\hline TNFS09(01) & Wed AM & 6846 & 14504 & 685 & 1450 & 2527 & 5354 & 1465 & 3105 \\
\hline & Wed PM & 6295 & 13336 & 629 & 1334 & 2035 & 4312 & 1424 & 3018 \\
\hline & Thurs AM & 5889 & 12476 & 589 & 1248 & 1600 & 3389 & 1415 & 2998 \\
\hline & Thurs PM & 5932 & 12568 & 593 & 1257 & 1762 & 3733 & 1385 & 2933 \\
\hline TNFS09(02) & Wed AM & 5493 & 11637 & 549 & 1164 & 420 & 890 & 126 & 267 \\
\hline & Wed PM & 5925 & 12552 & 592 & 1255 & 420 & 890 & 126 & 267 \\
\hline & Thurs AM & 4057 & 8595 & 406 & 860 & 216 & 458 & 65 & 137 \\
\hline & Thurs PM & 4830 & 10233 & 483 & 1023 & 276 & 585 & 83 & 175 \\
\hline TNFS10(01) & Wed AM & 10660 & 22585 & 1066 & 2258 & 7334 & 15537 & 1460 & 3094 \\
\hline & Wed PM & 12565 & 26621 & 1257 & 2662 & 6728 & 14254 & 2155 & 4566 \\
\hline & Thurs AM & 11859 & 25124 & 1186 & 2512 & 8341 & 17672 & 1587 & 3363 \\
\hline & Thurs PM & 10446 & 22131 & 1045 & 2213 & 7362 & 15597 & 1395 & 2956 \\
\hline
\end{tabular}




\begin{tabular}{|c|c|c|c|c|c|c|c|c|c|}
\hline \multirow[b]{2}{*}{ System ID } & \multirow[b]{2}{*}{ Day Period } & \multicolumn{2}{|c|}{ Supply airflow } & \multicolumn{2}{|c|}{$\begin{array}{r}\text { Uncertainty in } \\
\text { supply airflow }\end{array}$} & \multicolumn{2}{|c|}{ Outdoor airflow } & \multicolumn{2}{|c|}{$\begin{array}{c}\begin{array}{c}\text { Uncertainty in outdoor } \\
\text { airflow }\end{array} \\
\end{array}$} \\
\hline & & $\mathrm{L} / \mathrm{s}$ & $\mathrm{cfm}$ & $\mathrm{L} / \mathrm{s}$ & $\mathrm{cfm}$ & $\mathrm{L} / \mathrm{s}$ & $\mathrm{cfm}$ & $\mathrm{L} / \mathrm{s}$ & $\mathrm{cfm}$ \\
\hline \multirow{4}{*}{ TXFS01(01) } & Wed AM & 34668 & 73447 & 3467 & 7345 & & & & \\
\hline & Wed PM & 42496 & 90032 & 4250 & 9003 & 1933 & 4094 & 580 & 1228 \\
\hline & Thurs AM & 41862 & 88689 & 4186 & 8869 & 1789 & 3791 & 537 & 1137 \\
\hline & Thurs PM & 43118 & 91349 & 4312 & 9135 & 1720 & 3645 & 516 & 1094 \\
\hline \multirow[t]{4}{*}{ TXFS02(01) } & Wed AM & 8906 & 18868 & 891 & 1887 & 416 & 881 & 125 & 264 \\
\hline & Wed PM & 8008 & 16966 & 801 & 1697 & 400 & 847 & 120 & 254 \\
\hline & Thurs AM & 10773 & 22824 & 1077 & 2282 & 386 & 818 & 116 & 245 \\
\hline & Thurs PM & 9480 & 20085 & 948 & 2008 & 462 & 978 & 139 & 294 \\
\hline \multirow[t]{4}{*}{\begin{tabular}{|l|} 
TXFS02(02) \\
\end{tabular}} & Wed AM & 9588 & 20313 & 959 & 2031 & 450 & 954 & 135 & 286 \\
\hline & Wed PM & 10019 & 21226 & 1002 & 2123 & 462 & 978 & 139 & 294 \\
\hline & Thurs AM & 10486 & 22215 & 1049 & 2222 & 448 & 950 & 134 & 285 \\
\hline & Thurs PM & 9229 & 19552 & 923 & 1955 & 407 & 862 & 122 & 259 \\
\hline \multirow[t]{4}{*}{ TXFS07(01) } & Wed AM & 31610 & 66968 & 3161 & 6697 & 4042 & 8562 & 1212 & 2569 \\
\hline & Wed PM & 31610 & 66968 & 3161 & 6697 & 4475 & 9480 & 1342 & 2844 \\
\hline & Thurs AM & 29436 & 62362 & 2944 & 6236 & 4193 & 8884 & 1258 & 2665 \\
\hline & Thurs PM & 27596 & 58464 & 2760 & 5846 & 4382 & 9284 & 1315 & 2785 \\
\hline \multirow[t]{4}{*}{\begin{tabular}{|l|} 
TXFS08(01) \\
\end{tabular}} & Wed AM & 8107 & 17175 & 811 & 1718 & 373 & 791 & 112 & 237 \\
\hline & Wed PM & 8891 & 18837 & 889 & 1884 & 436 & 923 & 131 & 277 \\
\hline & Thurs AM & 8293 & 17570 & 829 & 1757 & 479 & 1014 & 144 & 304 \\
\hline & Thurs PM & 8646 & 18318 & 865 & 1832 & 512 & 1085 & 154 & 326 \\
\hline \multirow[t]{4}{*}{ TXFS08(02) } & Wed AM & 6913 & 14646 & 691 & 1465 & 366 & 776 & 110 & 233 \\
\hline & Wed PM & 7593 & 16087 & 759 & 1609 & 360 & 763 & 108 & 229 \\
\hline & Thurs AM & 6985 & 14799 & 699 & 1480 & 366 & 776 & 110 & 233 \\
\hline & Thurs PM & 7696 & 16305 & 770 & 1631 & 378 & 801 & 113 & 240 \\
\hline \multirow[t]{4}{*}{ TXFS09(01) } & Wed AM & 5083 & 10770 & 508 & 1077 & 975 & 2065 & 292 & 619 \\
\hline & Wed PM & 5168 & 10949 & 517 & 1095 & 947 & 2006 & 284 & 602 \\
\hline & Thurs AM & 5245 & 11112 & 525 & 1111 & 989 & 2095 & 297 & 628 \\
\hline & Thurs PM & 5191 & 10998 & 519 & 1100 & 1003 & 2124 & 301 & 637 \\
\hline \multirow[t]{4}{*}{ TXFS09(02) } & Wed AM & 5156 & 10924 & 516 & 1092 & 975 & 2065 & 292 & 619 \\
\hline & Wed PM & 5270 & 11164 & 527 & 1116 & 947 & 2006 & 284 & 602 \\
\hline & Thurs AM & 5092 & 10788 & 509 & 1079 & 989 & 2095 & 297 & 628 \\
\hline & Thurs PM & 5149 & 10909 & 515 & 1091 & 1003 & 2124 & 301 & 637 \\
\hline \multirow[t]{4}{*}{\begin{tabular}{|l|} 
TXFW05(01) \\
\end{tabular}} & Wed AM & 35400 & 74999 & 3540 & 7500 & 9156 & 19398 & 8633 & 18289 \\
\hline & Wed PM & 34115 & 72277 & 3412 & 7228 & 8465 & 17934 & 8417 & 17833 \\
\hline & Thurs AM & 41709 & 88366 & 4171 & 8837 & 24435 & 51768 & 6652 & 14094 \\
\hline & Thurs PM & 41826 & 88613 & 4183 & 8861 & 26065 & 55220 & 6313 & 13375 \\
\hline \multirow{4}{*}{ TXFW06(01) } & Wed AM & 47533 & 100703 & 4753 & 10070 & 47738 & 101137 & 14321 & 30341 \\
\hline & Wed PM & 39884 & 84498 & 3988 & 8450 & 39878 & 84486 & 11963 & 25346 \\
\hline & Thurs AM & 40703 & 86234 & 4070 & 8623 & 40752 & 86336 & 12225 & 25901 \\
\hline & Thurs PM & 45621 & 96652 & 4562 & 9665 & 45700 & 96820 & 13710 & 29046 \\
\hline \multirow[t]{4}{*}{ WAIW03(01) } & Wed AM & 2958 & 6266 & 296 & 627 & 2986 & 6327 & 896 & 1898 \\
\hline & Wed PM & 4093 & 8672 & 409 & 867 & 3627 & 7684 & 1088 & 2305 \\
\hline & Thurs AM & 3407 & 7217 & 341 & 722 & 3469 & 7350 & 1041 & 2205 \\
\hline & Thurs PM & 4040 & 8560 & 404 & 856 & 3718 & 7877 & 1115 & 2363 \\
\hline \multirow[t]{4}{*}{ WAIW04(01) } & Wed AM & 1570 & 3327 & 157 & 333 & 1528 & 3237 & 458 & 971 \\
\hline & Wed PM & 1570 & 3327 & 157 & 333 & 1555 & 3294 & 466 & 988 \\
\hline & Thurs AM & 1570 & 3327 & 157 & 333 & 1541 & 3266 & 462 & 980 \\
\hline & Thurs PM & 1537 & 3256 & 154 & 326 & 1541 & 3266 & 462 & 980 \\
\hline
\end{tabular}

\begin{tabular}{|l|c|c|c|c|c|c|c|c|}
\hline \# of values & 536 & & & & 510 & & & \\
\hline Mean & 11676 & 24737 & 1243 & 2633 & 5033 & 10662 & 2102 & 4453 \\
\hline StdDev & 12731 & 26972 & 1298 & 2750 & 9113 & 19307 & 3422 & 7250 \\
\hline Minimum & 49 & 104 & 12 & 25 & 0 & 0 & 9 & 19 \\
\hline 10th percentile & 2462 & 5215 & 252 & 534 & 219 & 465 & 89 & 188 \\
\hline 25th percentile & 4450 & 9428 & 449 & 951 & 473 & 1002 & 251 & 532 \\
\hline Median & 6861 & 14537 & 720 & 1525 & 1527 & 3235 & 590 & 1251 \\
\hline 75th percentile & 12259 & 25972 & 1514 & 3207 & 4606 & 9759 & 2580 & 5465 \\
\hline 90th percentile & 31161 & 66018 & 3200 & 6780 & 13374 & 28334 & 5921 & 12544 \\
\hline Maximum & 86266 & 182763 & 8626 & 18276 & 53438 & 113213 & 22124 & 46871 \\
\hline
\end{tabular}




\begin{tabular}{|c|c|c|c|c|c|c|c|c|c|}
\hline \multirow[b]{2}{*}{ System ID } & \multirow[b]{2}{*}{ Day Period } & \multicolumn{2}{|c|}{ Recirculation Airflow } & \multicolumn{2}{|c|}{$\begin{array}{l}\text { Uncertainty in } \\
\text { recirc. airflow }\end{array}$} & \multirow{2}{*}{$\begin{array}{c}\text { Outdoor air } \\
\text { fraction - } \\
\text { volumetric }\end{array}$} & \multirow{2}{*}{$\begin{array}{c}\text { Uncert. in } \\
\text { vol. OA } \\
\text { fraction }\end{array}$} & \multirow{2}{*}{$\begin{array}{c}\text { OA fraction } \\
\mathrm{CO}_{2}\end{array}$} & \multirow{2}{*}{$\begin{array}{c}\text { Uncert. in } \\
\mathrm{CO}_{2} \mathrm{OA} \\
\text { fraction }\end{array}$} \\
\hline & & $\mathrm{L} / \mathrm{s}$ & $\mathrm{cfm}$ & $\mathrm{L} / \mathrm{s}$ & $\mathrm{cfm}$ & & & & \\
\hline \multirow[t]{4}{*}{ ARFW01(01) } & Wed AM & & & & & 0.056 & 0.018 & 0.029 & 0.202 \\
\hline & Wed PM & & & & & 0.054 & 0.017 & 0.000 & 0.203 \\
\hline & Thurs AM & & & & & 0.056 & 0.018 & 0.086 & 0.203 \\
\hline & Thurs PM & & & & & 0.055 & 0.017 & 0.125 & 0.178 \\
\hline \multirow[t]{4}{*}{ ARFW01(02) } & Wed AM & & & & & 0.055 & 0.017 & 0.000 & 0.182 \\
\hline & Wed PM & & & & & 0.054 & 0.017 & 0.051 & 0.182 \\
\hline & Thurs AM & & & & & 0.058 & 0.018 & 0.125 & 0.178 \\
\hline & Thurs PM & & & & & 0.054 & 0.017 & 0.063 & 0.177 \\
\hline \multirow{4}{*}{ ARFW02(01) } & Wed AM & & & & & 0.819 & 0.259 & 0.667 & 2.833 \\
\hline & Wed PM & & & & & 0.841 & 0.266 & 0.611 & 0.921 \\
\hline & Thurs AM & & & & & & & & \\
\hline & Thurs PM & & & & & 0.846 & 0.267 & 0.750 & 1.473 \\
\hline \multirow[t]{4}{*}{ ARFW02(02) } & Wed AM & & & & & & & 0.833 & 0.767 \\
\hline & Wed PM & & & & & 0.796 & 0.252 & 0.235 & 0.741 \\
\hline & Thurs AM & & & & & & & & \\
\hline & Thurs PM & & & & & 0.817 & 0.258 & 0.850 & 0.928 \\
\hline \multirow[t]{4}{*}{ ARFW03(01) } & Wed AM & & & & & 0.042 & 0.013 & 0.120 & 0.251 \\
\hline & Wed PM & & & & & 0.024 & 0.008 & 0.014 & 0.249 \\
\hline & Thurs AM & & & & & 0.027 & 0.009 & 0.041 & 0.207 \\
\hline & Thurs PM & & & & & 0.027 & 0.009 & 0.055 & 0.279 \\
\hline \multirow[t]{4}{*}{ ARFW03(02) } & Wed AM & & & & & 0.110 & 0.035 & 0.031 & 0.217 \\
\hline & Wed PM & & & & & 0.114 & 0.036 & 0.032 & 0.228 \\
\hline & Thurs AM & & & & & 0.127 & 0.040 & 0.054 & 0.175 \\
\hline & Thurs PM & & & & & 0.121 & 0.038 & 0.233 & 0.202 \\
\hline \multirow[t]{4}{*}{ AZHS02(01) } & Wed AM & 2909 & 6162 & 873 & 1849 & 0.365 & 0.218 & 0.418 & 0.341 \\
\hline & Wed PM & 2761 & 5850 & 828 & 1755 & 0.485 & 0.190 & 0.320 & 0.594 \\
\hline & Thurs AM & 2990 & 6334 & 897 & 1900 & 0.294 & 0.236 & 0.169 & 0.806 \\
\hline & Thurs PM & 2769 & 5866 & 831 & 1760 & 0.370 & 0.217 & 0.400 & 1.015 \\
\hline AZHS02(02) & Wed AM & 1364 & 2889 & 409 & 867 & 0.463 & 0.195 & 0.353 & 0.401 \\
\hline & Wed PM & 1270 & 2691 & 381 & 807 & 0.494 & 0.188 & 0.547 & 0.630 \\
\hline & Thurs AM & 1495 & 3168 & 449 & 950 & 0.267 & 0.243 & 0.465 & 0.549 \\
\hline & Thurs PM & 1789 & 3789 & 537 & 1137 & 0.279 & 0.240 & 0.365 & 0.885 \\
\hline AZHS04(01) & Wed AM & 10463 & 22167 & 3139 & 6650 & 0.000 & 0.316 & 0.100 & 0.142 \\
\hline & Wed PM & 10875 & 23040 & 3262 & 6912 & 0.000 & 0.330 & 0.000 & 0.156 \\
\hline & Thurs AM & 9160 & 19405 & 2748 & 5822 & 0.105 & 0.287 & 0.746 & 0.774 \\
\hline & Thurs PM & 10635 & 22531 & 3190 & 6759 & 0.000 & 0.340 & 0.091 & 0.129 \\
\hline AZHS04(02) & Wed AM & 599 & 1269 & 180 & 381 & 0.141 & 0.056 & 0.297 & 0.144 \\
\hline & Wed PM & 598 & 1267 & 179 & 380 & 0.154 & 0.061 & 0.375 & 0.134 \\
\hline & Thurs AM & 637 & 1350 & 191 & 405 & 0.109 & 0.044 & 0.570 & 0.546 \\
\hline & Thurs PM & 691 & 1464 & 207 & 439 & 0.147 & 0.058 & 0.382 & 0.133 \\
\hline AZHW10(01) & Wed AM & & & & & 0.854 & 0.264 & 0.246 & 0.597 \\
\hline & Wed PM & & & & & 1.004 & 0.310 & 0.893 & 1.264 \\
\hline & Thurs AM & & & & & 0.999 & 0.309 & 0.946 & 1.739 \\
\hline & Thurs PM & & & & & 1.003 & 0.310 & 0.967 & 1.639 \\
\hline AZHW10(02) & Wed AM & & & & & & & 0.139 & 0.585 \\
\hline & Wed PM & & & & & & & 0.627 & 1.113 \\
\hline & Thurs AM & & & & & & & 0.446 & 1.383 \\
\hline & Thurs PM & & & & & & & 0.550 & 1.345 \\
\hline AZHW11(01) & Wed AM & 11499 & 24361 & 3450 & 7308 & 0.190 & 0.263 & 0.162 & 0.227 \\
\hline & Wed PM & 11827 & 25057 & 3548 & 7517 & 0.294 & 0.236 & 0.278 & 0.395 \\
\hline & Thurs AM & 11006 & 23317 & 3302 & 6995 & 0.334 & 0.226 & 0.196 & 0.300 \\
\hline & Thurs PM & 11909 & 25231 & 3573 & 7569 & 0.343 & 0.224 & 0.150 & 0.335 \\
\hline AZHW12(01) & Wed AM & & & & & 0.206 & 0.065 & & \\
\hline & Wed PM & & & & & 0.241 & 0.076 & & \\
\hline & Thurs AM & & & & & 0.045 & 0.014 & 0.041 & 0.323 \\
\hline & Thurs PM & & & & & 0.036 & 0.011 & 0.072 & 0.224 \\
\hline
\end{tabular}




\begin{tabular}{|c|c|c|c|c|c|c|c|c|c|}
\hline \multirow[b]{2}{*}{ System ID } & \multirow[b]{2}{*}{ Day Period } & \multicolumn{2}{|c|}{ Recirculation Airflow } & \multicolumn{2}{|c|}{$\begin{array}{l}\text { Uncertainty in } \\
\text { recirc. airflow }\end{array}$} & \multirow{2}{*}{$\begin{array}{c}\text { Outdoor air } \\
\text { fraction - } \\
\text { volumetric }\end{array}$} & \multirow{2}{*}{$\begin{array}{l}\text { Uncert. in } \\
\text { vol. OA } \\
\text { fraction }\end{array}$} & \multirow{2}{*}{$\begin{array}{l}\text { OA fraction } \\
\mathrm{CO}_{2}\end{array}$} & \multirow{2}{*}{$\begin{array}{c}\text { Uncert. in } \\
\mathrm{CO}_{2} \mathrm{OA} \\
\text { fraction }\end{array}$} \\
\hline & & $\mathrm{L} / \mathrm{s}$ & $\mathrm{cfm}$ & $\mathrm{L} / \mathrm{s}$ & $\mathrm{cfm}$ & & & & \\
\hline \multirow{4}{*}{\begin{tabular}{|l} 
AZHW12(02) \\
\end{tabular}} & Wed AM & & & & & 0.305 & 0.096 & & \\
\hline & Wed PM & & & & & 0.305 & 0.096 & & \\
\hline & Thurs AM & & & & & 0.309 & 0.098 & 0.269 & 0.468 \\
\hline & Thurs PM & & & & & 0.305 & 0.096 & 0.295 & 0.358 \\
\hline \multirow[t]{4}{*}{\begin{tabular}{|l} 
CAES17(01) \\
\end{tabular}} & Wed AM & 13246 & 28062 & 3974 & 8419 & 0.187 & 0.264 & 0.250 & 0.364 \\
\hline & Wed PM & 13354 & 28292 & 4006 & 8488 & 0.142 & 0.277 & 0.250 & 0.364 \\
\hline & Thurs AM & 7654 & 16216 & 2296 & 4865 & 0.564 & 0.174 & 0.167 & 0.478 \\
\hline & Thurs PM & 11617 & 24612 & 3485 & 7383 & 0.306 & 0.233 & 0.259 & 0.541 \\
\hline \multirow[t]{4}{*}{\begin{tabular}{|l} 
CAEW07(01) \\
\end{tabular}} & Wed AM & & & & & 0.307 & 0.097 & 0.585 & 1.638 \\
\hline & Wed PM & & & & & 0.869 & 0.275 & 1.148 & 2.340 \\
\hline & Thurs AM & & & & & 0.763 & 0.241 & 0.222 & 0.805 \\
\hline & Thurs PM & & & & & 1.050 & 0.332 & 1.200 & 4.418 \\
\hline \multirow[t]{4}{*}{\begin{tabular}{|l} 
CAEW09(01) \\
\end{tabular}} & Wed AM & & & & & 0.317 & 0.100 & 0.118 & 0.838 \\
\hline & Wed PM & & & & & 0.268 & 0.085 & 0.368 & 0.603 \\
\hline & Thurs AM & & & & & 0.144 & 0.045 & 0.500 & 1.976 \\
\hline & Thurs PM & & & & & 0.149 & 0.047 & 0.281 & 0.480 \\
\hline \multirow[t]{4}{*}{\begin{tabular}{|l|} 
CAJS01(01) \\
\end{tabular}} & Wed AM & & & & & 1.000 & 0.316 & 0.000 & 0.710 \\
\hline & Wed PM & & & & & 1.000 & 0.316 & 0.000 & 0.986 \\
\hline & Thurs AM & & & & & 1.000 & 0.316 & 0.000 & 0.710 \\
\hline & Thurs PM & & & & & 1.000 & 0.316 & 0.000 & 1.775 \\
\hline \multirow[t]{4}{*}{\begin{tabular}{|l|} 
CAJS01(02) \\
\end{tabular}} & Wed AM & & & & & 1.000 & 0.316 & 0.286 & 1.051 \\
\hline & Wed PM & & & & & 1.000 & 0.316 & 0.722 & 0.969 \\
\hline & Thurs AM & & & & & 1.000 & 0.316 & 0.537 & 0.743 \\
\hline & Thurs PM & & & & & 1.000 & 0.316 & 0.556 & 0.899 \\
\hline \multirow[t]{4}{*}{\begin{tabular}{|l|} 
CAJS01(03) \\
\end{tabular}} & Wed AM & & & & & 1.000 & 0.316 & & \\
\hline & Wed PM & & & & & 1.000 & 0.316 & & \\
\hline & Thurs AM & & & & & 1.000 & 0.316 & 0.200 & 0.577 \\
\hline & Thurs PM & & & & & 1.000 & 0.316 & 0.538 & 1.236 \\
\hline \begin{tabular}{|l} 
CAJS02(01) \\
\end{tabular} & Wed AM & & & & & 0.847 & 0.268 & 0.000 & 7.100 \\
\hline & Wed PM & & & & & 0.918 & 0.290 & 1.000 & 4.000 \\
\hline & Thurs AM & & & & & 0.979 & 0.310 & 0.400 & 1.523 \\
\hline & Thurs PM & & & & & 1.082 & 0.342 & 0.444 & 1.433 \\
\hline \begin{tabular}{|l} 
CAJS03(01) \\
\end{tabular} & Wed AM & & & & & 1.000 & 0.316 & 0.143 & 2.551 \\
\hline & Wed PM & & & & & 1.000 & 0.316 & 0.900 & 2.378 \\
\hline & Thurs AM & & & & & 1.000 & 0.316 & 0.488 & 1.919 \\
\hline & Thurs PM & & & & & 0.996 & 0.315 & 0.667 & 1.889 \\
\hline \begin{tabular}{|l} 
CAJS21(01) \\
\end{tabular} & Wed AM & & & & & 0.208 & 0.066 & 0.200 & 0.361 \\
\hline & Wed PM & & & & & 0.244 & 0.077 & 0.333 & 0.497 \\
\hline & Thurs AM & & & & & 0.361 & 0.114 & 0.278 & 0.815 \\
\hline & Thurs PM & & & & & 0.287 & 0.091 & 0.327 & 0.715 \\
\hline \begin{tabular}{|l|l} 
CAJS21(02) \\
\end{tabular} & Wed AM & & & & & 1.000 & 0.316 & & \\
\hline & Wed PM & & & & & 1.000 & 0.316 & & \\
\hline & Thurs AM & & & & & 1.000 & 0.316 & & \\
\hline & Thurs PM & & & & & 1.000 & 0.316 & & \\
\hline \begin{tabular}{|l} 
CAJS222(01) \\
\end{tabular} & Wed AM & 4260 & 9025 & 1278 & 2708 & 0.084 & 0.293 & 0.171 & 0.410 \\
\hline & Wed PM & 4798 & 10165 & 1439 & 3050 & 0.144 & 0.276 & 0.175 & 0.359 \\
\hline & Thurs AM & 3565 & 7553 & 1069 & 2266 & 0.207 & 0.259 & 0.133 & 0.476 \\
\hline & Thurs PM & 4395 & 9310 & 1318 & 2793 & 0.211 & 0.258 & 0.070 & 0.330 \\
\hline \begin{tabular}{|l} 
CAJS23(01) \\
\end{tabular} & Wed AM & & & & & 0.074 & 0.023 & 0.208 & 0.301 \\
\hline & Wed PM & & & & & 0.102 & 0.032 & 0.053 & 0.373 \\
\hline & Thurs AM & & & & & 0.086 & 0.027 & 0.000 & 0.394 \\
\hline & Thurs PM & & & & & 0.095 & 0.030 & 0.000 & 0.394 \\
\hline \begin{tabular}{|l|} 
CAJW18(01) \\
\end{tabular} & Wed AM & & & & & 0.081 & 0.026 & 0.224 & 0.401 \\
\hline & Wed PM & & & & & 0.076 & 0.024 & 0.174 & 0.353 \\
\hline & Thurs AM & & & & & 0.088 & 0.028 & 0.170 & 0.597 \\
\hline & Thurs PM & & & & & 0.078 & 0.025 & 0.148 & 0.379 \\
\hline
\end{tabular}




\begin{tabular}{|c|c|c|c|c|c|c|c|c|c|}
\hline \multirow[b]{2}{*}{ System ID } & \multirow[b]{2}{*}{ Day Period } & \multicolumn{2}{|c|}{ Recirculation Airflow } & \multicolumn{2}{|c|}{$\begin{array}{l}\text { Uncertainty in } \\
\text { recirc. airflow }\end{array}$} & \multirow{2}{*}{\begin{tabular}{|c} 
Outdoor air \\
fraction - \\
volumetric
\end{tabular}} & \multirow{2}{*}{$\begin{array}{c}\text { Uncert. in } \\
\text { vol. OA } \\
\text { fraction }\end{array}$} & \multirow{2}{*}{$\begin{array}{c}\mathrm{OA} \text { fraction } \\
-\mathrm{CO}_{2}\end{array}$} & \multirow{2}{*}{$\begin{array}{l}\text { Uncert. in } \\
\mathrm{CO}_{2} \mathrm{OA} \\
\text { fraction }\end{array}$} \\
\hline & & $\mathrm{L} / \mathrm{s}$ & $\mathrm{cfm}$ & $\mathrm{L} / \mathrm{s}$ & $\mathrm{cfm}$ & & & & \\
\hline \multirow[t]{4}{*}{ CAJW19(01) } & Wed AM & 8940 & 18941 & 2682 & 5682 & 0.497 & 0.188 & 0.374 & 1.054 \\
\hline & Wed PM & 10385 & 22001 & 3115 & 6600 & 0.404 & 0.209 & 0.506 & 1.014 \\
\hline & Thurs AM & 9016 & 19101 & 2705 & 5730 & 0.493 & 0.189 & 0.419 & 0.776 \\
\hline & Thurs PM & 11357 & 24062 & 3407 & 7218 & 0.327 & 0.228 & 0.379 & 1.030 \\
\hline \multirow[t]{4}{*}{\begin{tabular}{|l} 
CAJW20(01) \\
\end{tabular}} & Wed AM & & & & & 1.205 & 0.381 & 0.967 & 1.002 \\
\hline & Wed PM & & & & & 1.144 & 0.362 & 0.955 & 1.051 \\
\hline & Thurs AM & & & & & 1.137 & 0.360 & 1.061 & 0.609 \\
\hline & Thurs PM & & & & & 1.123 & 0.355 & 0.970 & 0.743 \\
\hline \multirow[t]{6}{*}{ CAJW24(01) } & Tues AM & & & & & 0.691 & 0.219 & 0.143 & 1.020 \\
\hline & Tues PM & & & & & 0.036 & 0.011 & 0.033 & 0.236 \\
\hline & Wed AM & & & & & 0.691 & 0.219 & 0.143 & 1.020 \\
\hline & Wed PM & & & & & 0.033 & 0.011 & 0.033 & 0.236 \\
\hline & Thurs AM & & & & & 0.700 & 0.222 & 0.750 & 1.105 \\
\hline & Thurs PM & & & & & 0.886 & 0.280 & 0.400 & 1.523 \\
\hline \multirow[t]{4}{*}{ CAJW25(01) } & Wed AM & & & & & 0.539 & 0.170 & 0.462 & 0.599 \\
\hline & Wed PM & & & & & 0.956 & 0.302 & 0.842 & 0.973 \\
\hline & Thurs AM & & & & & 0.710 & 0.225 & 0.333 & 0.828 \\
\hline & Thurs PM & & & & & 1.024 & 0.324 & 0.842 & 0.973 \\
\hline \multirow[t]{4}{*}{\begin{tabular}{|l} 
CAJW26(01) \\
\end{tabular}} & Wed AM & & & & & 1.136 & 0.359 & 0.667 & 1.133 \\
\hline & Wed PM & & & & & 1.112 & 0.351 & 0.500 & 1.129 \\
\hline & Thurs AM & & & & & 1.067 & 0.338 & 1.000 & 1.250 \\
\hline & Thurs PM & & & & & 0.944 & 0.298 & 1.000 & 0.870 \\
\hline \multirow[t]{4}{*}{\begin{tabular}{|l} 
COAS02(01) \\
\end{tabular}} & Wed AM & 10512 & 22272 & 3154 & 6681 & 0.072 & 0.029 & 0.000 & 0.568 \\
\hline & Wed PM & 8969 & 19001 & 2691 & 5700 & 0.108 & 0.043 & 0.000 & 0.473 \\
\hline & Thurs AM & 10022 & 21232 & 3007 & 6370 & 0.090 & 0.037 & 0.143 & 0.408 \\
\hline & Thurs PM & 10512 & 22272 & 3154 & 6681 & 0.129 & 0.051 & 0.143 & 0.408 \\
\hline COAS04(01) & Wed AM & 33430 & 70825 & 10029 & 21247 & 0.023 & 0.310 & 0.372 & 0.623 \\
\hline & Wed PM & 32611 & 69091 & 9783 & 20727 & 0.065 & 0.298 & 0.270 & 0.495 \\
\hline & Thurs AM & 33376 & 70711 & 10013 & 21213 & 0.005 & 0.315 & 0.114 & 0.407 \\
\hline & Thurs PM & 34907 & 73953 & 10472 & 22186 & 0.000 & 0.321 & 0.000 & 0.507 \\
\hline COAS06(01) & Wed AM & & & & & 0.241 & 0.076 & 0.216 & 0.289 \\
\hline & Wed PM & & & & & 0.207 & 0.066 & 0.333 & 0.191 \\
\hline & Thurs AM & & & & & 0.167 & 0.053 & 0.065 & 0.308 \\
\hline & Thurs PM & & & & & 0.175 & 0.055 & 0.055 & 0.216 \\
\hline FLDW07(02) & Wed AM & 6523 & 13819 & 1957 & 4146 & 0.130 & 0.052 & 0.000 & 0.309 \\
\hline & Wed PM & 5764 & 12212 & 1729 & 3664 & 0.148 & 0.059 & 0.000 & 0.284 \\
\hline & Thurs AM & 5357 & 11348 & 1607 & 3405 & 0.155 & 0.061 & 0.040 & 0.283 \\
\hline & Thurs PM & 5873 & 12442 & 1762 & 3733 & 0.150 & 0.060 & 0.032 & 0.228 \\
\hline FLDW08(01) & Wed AM & & & & & 0.187 & 0.059 & 0.255 & 0.265 \\
\hline & Wed PM & & & & & 0.114 & 0.036 & 0.200 & 0.240 \\
\hline & Thurs AM & & & & & 0.123 & 0.039 & 0.143 & 1.020 \\
\hline & Thurs PM & & & & & 0.671 & 0.212 & 1.000 & 2.500 \\
\hline FLDW10(01) & Wed AM & & & & & 0.077 & 0.024 & 0.250 & 0.729 \\
\hline & Wed PM & & & & & 0.087 & 0.028 & 0.150 & 0.715 \\
\hline & Thurs AM & & & & & 0.094 & 0.030 & 0.192 & 0.554 \\
\hline & Thurs PM & & & & & 0.067 & 0.021 & 0.077 & 0.546 \\
\hline FLGS01(01) & Thurs AM & & & & & 0.195 & 0.062 & 0.268 & 0.357 \\
\hline & Thurs PM & & & & & 0.185 & 0.059 & 0.500 & 0.395 \\
\hline & Fri AM & & & & & 0.196 & 0.062 & 0.237 & 0.382 \\
\hline & Fri PM & & & & & 0.198 & 0.063 & 0.200 & 0.412 \\
\hline FLGS04(01) & Wed AM & & & & & 0.035 & 0.011 & 0.084 & 0.157 \\
\hline & Wed PM & & & & & 0.037 & 0.012 & 0.041 & 0.125 \\
\hline & Thurs AM & & & & & 0.034 & 0.011 & 0.108 & 0.154 \\
\hline & Thurs PM & & & & & 0.030 & 0.010 & 0.016 & 0.124 \\
\hline FLGS04(02) & Wed AM & & & & & 0.042 & 0.013 & 0.053 & 0.156 \\
\hline & Wed PM & & & & & 0.040 & 0.013 & 0.028 & 0.140 \\
\hline & Thurs AM & & & & & 0.041 & 0.013 & 0.069 & 0.152 \\
\hline & Thurs PM & & & & & 0.041 & 0.013 & 0.039 & 0.138 \\
\hline
\end{tabular}




\begin{tabular}{|c|c|c|c|c|c|c|c|c|c|}
\hline \multirow[b]{2}{*}{ System ID } & \multirow[b]{2}{*}{ Day Period } & \multicolumn{2}{|c|}{ Recirculation Airflow } & \multicolumn{2}{|c|}{$\begin{array}{l}\text { Uncertainty in } \\
\text { recirc. airflow }\end{array}$} & \multirow{2}{*}{$\begin{array}{c}\text { Outdoor air } \\
\text { fraction - } \\
\text { volumetric }\end{array}$} & \multirow{2}{*}{$\begin{array}{c}\text { Uncert. in } \\
\text { vol. OA } \\
\text { fraction }\end{array}$} & \multirow{2}{*}{$\begin{array}{c}\text { OA fraction } \\
\mathrm{CO}_{2}\end{array}$} & \multirow{2}{*}{$\begin{array}{c}\text { Uncert. in } \\
\mathrm{CO}_{2} \mathrm{OA} \\
\text { fraction }\end{array}$} \\
\hline & & $\mathrm{L} / \mathrm{s}$ & $\mathrm{cfm}$ & $\mathrm{L} / \mathrm{s}$ & $\mathrm{cfm}$ & & & & \\
\hline \multirow[t]{4}{*}{ FLGS11(01) } & Wed AM & & & & & 0.161 & 0.051 & 0.045 & 0.211 \\
\hline & Wed PM & & & & & 0.104 & 0.033 & 0.034 & 0.122 \\
\hline & Thurs AM & & & & & 0.189 & 0.060 & 0.138 & 0.246 \\
\hline & Thurs PM & & & & & 0.088 & 0.028 & 0.038 & 0.134 \\
\hline \multirow[t]{4}{*}{ FLGS11(02) } & Wed AM & & & & & 0.144 & 0.045 & 0.036 & 0.257 \\
\hline & Wed PM & & & & & 0.111 & 0.035 & 0.030 & 0.143 \\
\hline & Thurs AM & & & & & 0.162 & 0.051 & 0.074 & 0.263 \\
\hline & Thurs PM & & & & & 0.111 & 0.035 & 0.047 & 0.165 \\
\hline \multirow[t]{4}{*}{ FLGS12(01) } & Wed AM & 8386 & 17766 & 2516 & 5330 & 0.164 & 0.065 & & \\
\hline & Wed PM & 8003 & 16955 & 2401 & 5086 & 0.171 & 0.067 & 0.125 & 0.178 \\
\hline & Thurs AM & 7322 & 15512 & 2196 & 4653 & 0.185 & 0.072 & 0.085 & 0.241 \\
\hline & Thurs PM & 7237 & 15331 & 2171 & 4599 & 0.175 & 0.069 & 0.156 & 0.159 \\
\hline \multirow{4}{*}{ GADS01(01) } & Wed AM & 3304 & 6999 & 991 & 2100 & 0.396 & 0.147 & 0.250 & 0.729 \\
\hline & Wed PM & 3996 & 8465 & 1199 & 2540 & 0.322 & 0.121 & 0.364 & 0.684 \\
\hline & Thurs AM & 3209 & 6799 & 963 & 2040 & 0.419 & 0.155 & 0.333 & 0.621 \\
\hline & Thurs PM & 3524 & 7466 & 1057 & 2240 & 0.378 & 0.140 & 0.500 & 0.791 \\
\hline \multirow[t]{4}{*}{ GADS02(01) } & Wed AM & & & & & 0.162 & 0.051 & 0.171 & 0.350 \\
\hline & Wed PM & & & & & 0.159 & 0.050 & 0.167 & 0.239 \\
\hline & Thurs AM & & & & & 0.220 & 0.069 & 0.083 & 0.394 \\
\hline & Thurs PM & & & & & 0.162 & 0.051 & 0.185 & 0.266 \\
\hline GADS02(02) & Wed AM & & & & & 0.253 & 0.080 & 0.125 & 0.356 \\
\hline & Wed PM & & & & & 0.196 & 0.062 & 0.175 & 0.252 \\
\hline & Thurs AM & & & & & 0.208 & 0.066 & 0.125 & 0.445 \\
\hline & Thurs PM & & & & & 0.184 & 0.058 & 0.188 & 0.300 \\
\hline GADS03(01) & Wed AM & & & & & 0.080 & 0.025 & 0.091 & 0.125 \\
\hline & Wed PM & & & & & 0.085 & 0.027 & 0.000 & 0.101 \\
\hline & Thurs AM & & & & & 0.085 & 0.027 & 0.049 & 0.137 \\
\hline & Thurs PM & & & & & 0.087 & 0.027 & 0.000 & 0.105 \\
\hline ILBS01(01) & Wed AM & & & & & & & 0.111 & 0.264 \\
\hline & Wed PM & & & & & & & 0.000 & 0.189 \\
\hline & Thurs AM & & & & & & & 0.222 & 0.402 \\
\hline & Thurs PM & & & & & & & 0.160 & 0.286 \\
\hline ILBS01(02) & Wed AM & & & & & & & 0.263 & 0.385 \\
\hline & Wed PM & & & & & & & 0.222 & 0.322 \\
\hline & Thurs AM & & & & & & & 0.000 & 0.458 \\
\hline & Thurs PM & & & & & & & 0.000 & 0.167 \\
\hline ILBS02(01) & Wed AM & 7636 & 16177 & 2291 & 4853 & 0.083 & 0.026 & 0.000 & 0.645 \\
\hline & Wed PM & 6207 & 13149 & 1862 & 3945 & 0.073 & 0.023 & 0.074 & 0.525 \\
\hline & Thurs AM & 6942 & 14706 & 2082 & 4412 & 0.068 & 0.021 & 0.125 & 0.891 \\
\hline & Thurs PM & 6737 & 14274 & 2021 & 4282 & 0.076 & 0.024 & 0.000 & 0.789 \\
\hline ILBS03(01) & Wed AM & 10354 & 21935 & 3106 & 6581 & 0.362 & 0.219 & 0.333 & 0.497 \\
\hline & Wed PM & 10904 & 23101 & 3271 & 6930 & 0.356 & 0.220 & 0.286 & 0.420 \\
\hline & Thurs AM & 8723 & 18481 & 2617 & 5544 & 0.468 & 0.194 & 0.333 & 0.497 \\
\hline & Thurs PM & 9076 & 19229 & 2723 & 5769 & 0.421 & 0.205 & 0.167 & 0.478 \\
\hline LAGW04(01) & Wed AM & & & & & 0.062 & 0.020 & 0.333 & 0.994 \\
\hline & Wed PM & & & & & 0.045 & 0.014 & 0.000 & 0.568 \\
\hline & Thurs AM & & & & & 0.061 & 0.019 & 0.286 & 0.420 \\
\hline & Thurs PM & & & & & 0.054 & 0.017 & 0.152 & 0.433 \\
\hline LAGW04(02) & Wed AM & & & & & 0.073 & 0.023 & 0.333 & 0.994 \\
\hline & Wed PM & & & & & 0.077 & 0.025 & 0.125 & 0.356 \\
\hline & Thurs AM & & & & & 0.081 & 0.026 & 0.125 & 0.356 \\
\hline & Thurs PM & & & & & 0.075 & 0.024 & 0.111 & 0.316 \\
\hline LAGW05(01) & Wed AM & 6913 & 14646 & 2074 & 4394 & 0.190 & 0.063 & & \\
\hline & Wed PM & 6780 & 14365 & 2034 & 4309 & 0.219 & 0.073 & & \\
\hline & Thurs AM & 6714 & 14224 & 2014 & 4267 & 0.202 & 0.067 & & \\
\hline & Thurs PM & 6758 & 14317 & 2027 & 4295 & 0.217 & 0.072 & & \\
\hline LAGW05(02) & Wed AM & & & & & & & & \\
\hline & Wed PM & & & & & & & 0.443 & 0.236 \\
\hline & \begin{tabular}{|l} 
Thurs AM \\
\end{tabular} & & & & & & & & \\
\hline & Thurs PM & & & & & & & & \\
\hline
\end{tabular}




\begin{tabular}{|c|c|c|c|c|c|c|c|c|c|}
\hline \multirow[b]{2}{*}{ System ID } & \multirow[b]{2}{*}{ Day Period } & \multicolumn{2}{|c|}{ Recirculation Airflow } & \multicolumn{2}{|c|}{$\begin{array}{l}\text { Uncertainty in } \\
\text { recirc. airflow }\end{array}$} & \multirow{2}{*}{$\begin{array}{c}\text { Outdoor air } \\
\text { fraction - } \\
\text { volumetric }\end{array}$} & \multirow{2}{*}{$\begin{array}{c}\text { Uncert. in } \\
\text { vol. OA } \\
\text { fraction }\end{array}$} & \multirow{2}{*}{$\begin{array}{c}\text { OA fraction } \\
\mathrm{CO}_{2}\end{array}$} & \multirow{2}{*}{$\begin{array}{c}\text { Uncert. in } \\
\mathrm{CO}_{2} \mathrm{OA} \\
\text { fraction }\end{array}$} \\
\hline & & $\mathrm{L} / \mathrm{s}$ & $\mathrm{cfm}$ & $\mathrm{L} / \mathrm{s}$ & $\mathrm{cfm}$ & & & & \\
\hline \multirow[t]{4}{*}{ LAGW06(01) } & Wed AM & & & & & 0.126 & 0.040 & & \\
\hline & Wed PM & & & & & 0.122 & 0.039 & & \\
\hline & Thurs AM & & & & & 0.122 & 0.039 & & \\
\hline & Thurs PM & & & & & 0.123 & 0.039 & & \\
\hline \multirow[t]{4}{*}{ LAGW06(02) } & Wed AM & & & & & & & & \\
\hline & Wed PM & & & & & & & & \\
\hline & Thurs AM & & & & & & & & \\
\hline & Thurs PM & & & & & & & & \\
\hline \multirow[t]{4}{*}{ MABW05(01) } & Wed AM & 3767 & 7980 & 1130 & 2394 & 0.099 & 0.288 & 0.178 & 0.206 \\
\hline & Wed PM & 5013 & 10621 & 1504 & 3186 & 0.279 & 0.240 & 0.292 & 0.192 \\
\hline & Thurs AM & 5268 & 11161 & 1580 & 3348 & 0.196 & 0.262 & 0.383 & 0.246 \\
\hline & Thurs PM & 5098 & 10801 & 1529 & 3240 & 0.254 & 0.246 & 0.250 & 0.190 \\
\hline \multirow[t]{4}{*}{ MABW05(02) } & Wed AM & 5466 & 11581 & 1640 & 3474 & 0.104 & 0.287 & 0.137 & 0.192 \\
\hline & Wed PM & 6458 & 13681 & 1937 & 4104 & 0.000 & 0.339 & 0.101 & 0.184 \\
\hline & Thurs AM & 6118 & 12961 & 1835 & 3888 & 0.050 & 0.302 & 0.059 & 0.244 \\
\hline & Thurs PM & 6684 & 14161 & 2005 & 4248 & 0.006 & 0.314 & 0.101 & 0.179 \\
\hline \multirow[t]{4}{*}{ MABW06(01) } & Wed AM & & & & & 0.930 & 0.294 & 0.857 & 0.665 \\
\hline & Wed PM & & & & & 0.966 & 0.305 & 0.926 & 0.714 \\
\hline & Thurs AM & & & & & 0.967 & 0.306 & 0.839 & 0.595 \\
\hline & Thurs PM & & & & & 0.969 & 0.306 & 0.778 & 0.398 \\
\hline \multirow[t]{4}{*}{ MABW08(01) } & Wed AM & 4828 & 10228 & 1448 & 3068 & 0.626 & 0.163 & 0.500 & 0.791 \\
\hline & Wed PM & 4411 & 9346 & 1323 & 2804 & 0.673 & 0.155 & 0.593 & 0.609 \\
\hline & Thurs AM & 5898 & 12496 & 1769 & 3749 & 0.532 & 0.180 & 0.500 & 0.791 \\
\hline & Thurs PM & 5353 & 11341 & 1606 & 3402 & 0.585 & 0.170 & 0.500 & 0.791 \\
\hline \multirow[t]{4}{*}{ MABW08(02) } & Wed AM & 426 & 903 & 128 & 271 & 0.966 & 0.403 & 0.900 & 0.951 \\
\hline & Wed PM & 456 & 966 & 137 & 290 & 0.962 & 0.400 & 0.963 & 0.727 \\
\hline & Thurs AM & 446 & 945 & 134 & 284 & 0.961 & 0.400 & 1.000 & 1.000 \\
\hline & Thurs PM & 595 & 1260 & 178 & 378 & 0.949 & 0.393 & 1.000 & 1.000 \\
\hline MDDS01(01) & Wed AM & 18850 & 39936 & 5655 & 11981 & 0.113 & 0.284 & 0.138 & 0.615 \\
\hline & Wed PM & 21269 & 45060 & 6381 & 13518 & 0.063 & 0.298 & 0.565 & 3.531 \\
\hline & Thurs AM & 25084 & 53142 & 7525 & 15943 & 0.000 & 0.385 & 0.083 & 0.651 \\
\hline & Thurs PM & 21969 & 46543 & 6591 & 13963 & 0.000 & 0.346 & 0.000 & 0.710 \\
\hline MDDS03(01) & Wed AM & & & & & 0.157 & 0.050 & 0.143 & 0.204 \\
\hline & Wed PM & & & & & 0.132 & 0.042 & 0.167 & 0.478 \\
\hline & Thurs AM & & & & & 0.142 & 0.045 & 0.125 & 0.356 \\
\hline & Thurs PM & & & & & 0.136 & 0.043 & 0.200 & 0.288 \\
\hline MDDS03(02) & Wed AM & & & & & 0.032 & 0.010 & 0.333 & 2.485 \\
\hline & Wed PM & & & & & 0.016 & 0.005 & 0.012 & 0.175 \\
\hline & Thurs AM & & & & & 0.032 & 0.010 & 0.000 & 0.284 \\
\hline & Thurs PM & & & & & 0.032 & 0.010 & 0.000 & 0.237 \\
\hline MDDS04(01) & Wed AM & 2266 & 4800 & 680 & 1440 & 0.114 & 0.284 & 0.023 & 0.202 \\
\hline & Wed PM & 2247 & 4760 & 674 & 1428 & 0.112 & 0.285 & 0.000 & 0.145 \\
\hline & Thurs AM & 2285 & 4840 & 685 & 1452 & 0.102 & 0.288 & 0.070 & 0.166 \\
\hline & Thurs PM & 2228 & 4720 & 668 & 1416 & 0.085 & 0.292 & 0.021 & 0.149 \\
\hline MDDS04(02) & Wed AM & 1570 & 3325 & 471 & 998 & 0.267 & 0.243 & 0.197 & 0.295 \\
\hline & Wed PM & 1469 & 3112 & 441 & 933 & 0.237 & 0.251 & 0.143 & 0.255 \\
\hline & Thurs AM & 1547 & 3278 & 464 & 983 & 0.224 & 0.254 & 0.141 & 0.264 \\
\hline & Thurs PM & 1435 & 3040 & 431 & 912 & 0.260 & 0.245 & 0.104 & 0.205 \\
\hline MIBW01(01) & Wed AM & 1159 & 2455 & 348 & 737 & 0.594 & 0.168 & 0.469 & 0.319 \\
\hline & Wed PM & 1042 & 2207 & 313 & 662 & 0.652 & 0.159 & 0.286 & 0.420 \\
\hline & Thurs AM & 1259 & 2666 & 378 & 800 & 0.560 & 0.175 & 0.269 & 0.563 \\
\hline & Thurs PM & 1478 & 3131 & 443 & 939 & 0.509 & 0.185 & 0.345 & 0.516 \\
\hline MIBW01(02) & Wed AM & 2093 & 4433 & 628 & 1330 & 0.088 & 0.291 & 0.250 & 0.607 \\
\hline & Wed PM & 1712 & 3627 & 514 & 1088 & 0.381 & 0.214 & 0.222 & 0.537 \\
\hline & Thurs AM & & & & & & & 0.105 & 0.748 \\
\hline & Thurs PM & & & & & & & 0.345 & 0.516 \\
\hline
\end{tabular}




\begin{tabular}{|c|c|c|c|c|c|c|c|c|c|}
\hline \multirow[b]{2}{*}{ System ID } & \multirow[b]{2}{*}{ Day Period } & \multicolumn{2}{|c|}{ Recirculation Airflow } & \multicolumn{2}{|c|}{$\begin{array}{l}\text { Uncertainty in } \\
\text { recirc. airflow }\end{array}$} & \multirow{2}{*}{$\begin{array}{c}\text { Outdoor air } \\
\text { fraction - } \\
\text { volumetric }\end{array}$} & \multirow{2}{*}{$\begin{array}{l}\text { Uncert. in } \\
\text { vol. OA } \\
\text { fraction }\end{array}$} & \multirow{2}{*}{$\begin{array}{l}\text { OA fraction } \\
\mathrm{CO}_{2}\end{array}$} & \multirow{2}{*}{$\begin{array}{c}\text { Uncert. in } \\
\mathrm{CO}_{2} \mathrm{OA} \\
\text { fraction }\end{array}$} \\
\hline & & $\mathrm{L} / \mathrm{s}$ & $\mathrm{cfm}$ & $\mathrm{L} / \mathrm{s}$ & $\mathrm{cfm}$ & & & & \\
\hline \multirow{4}{*}{ MIBW03(01) } & Wed AM & 11505 & 24374 & 3451 & 7312 & 0.285 & 0.238 & 0.250 & 0.364 \\
\hline & Wed PM & 12512 & 26509 & 3754 & 7953 & 0.218 & 0.256 & 0.353 & 0.441 \\
\hline & Thurs AM & 12368 & 26203 & 3710 & 7861 & 0.244 & 0.249 & 0.313 & 0.463 \\
\hline & Thurs PM & 9264 & 19626 & 2779 & 5888 & 0.337 & 0.225 & 0.667 & 0.567 \\
\hline \multirow[t]{4}{*}{ MIBW04(01) } & Wed AM & 3002 & 6361 & 901 & 1908 & 0.305 & 0.233 & 0.454 & 0.424 \\
\hline & Wed PM & 2700 & 5720 & 810 & 1716 & 0.373 & 0.216 & 0.356 & 0.504 \\
\hline & Thurs AM & 3767 & 7980 & 1130 & 2394 & 0.251 & 0.247 & 0.326 & 0.418 \\
\hline & Thurs PM & 3455 & 7321 & 1037 & 2196 & 0.323 & 0.229 & 0.408 & 0.502 \\
\hline \multirow[t]{4}{*}{\begin{tabular}{|l} 
MIBW04(02) \\
\end{tabular}} & Wed AM & 3455 & 7321 & 1037 & 2196 & 0.386 & 0.213 & 0.333 & 0.414 \\
\hline & Wed PM & 3540 & 7500 & 1062 & 2250 & 0.347 & 0.223 & 0.400 & 0.508 \\
\hline & Thurs AM & 3795 & 8041 & 1139 & 2412 & 0.259 & 0.245 & 0.217 & 0.524 \\
\hline & Thurs PM & 3474 & 7360 & 1042 & 2208 & 0.409 & 0.208 & 0.357 & 0.536 \\
\hline \multirow[t]{4}{*}{\begin{tabular}{|l} 
MNBW01(01) \\
\end{tabular}} & Wed AM & & & & & 0.259 & 0.082 & 0.500 & 0.395 \\
\hline & Wed PM & & & & & 0.231 & 0.073 & 0.405 & 0.412 \\
\hline & Thurs AM & & & & & 0.250 & 0.079 & 0.333 & 0.497 \\
\hline & Thurs PM & & & & & 0.247 & 0.078 & 0.429 & 0.440 \\
\hline \multirow[t]{4}{*}{\begin{tabular}{|l} 
MNBW02(01) \\
\end{tabular}} & Wed AM & & & & & 0.278 & 0.088 & 0.412 & 0.450 \\
\hline & Wed PM & & & & & 0.295 & 0.093 & 0.400 & 0.609 \\
\hline & Thurs AM & & & & & 0.416 & 0.131 & 0.400 & 0.609 \\
\hline & Thurs PM & & & & & 0.418 & 0.132 & 0.400 & 0.609 \\
\hline \multirow[t]{4}{*}{\begin{tabular}{|l} 
MNBW02(02) \\
\end{tabular}} & Wed AM & & & & & 0.295 & 0.093 & 0.250 & 0.729 \\
\hline & Wed PM & & & & & 0.425 & 0.134 & 0.333 & 0.994 \\
\hline & Thurs AM & & & & & 0.624 & 0.197 & 0.333 & 0.994 \\
\hline & Thurs PM & & & & & 0.457 & 0.145 & 0.500 & 1.581 \\
\hline \multirow[t]{4}{*}{\begin{tabular}{|l} 
MNBW04(01) \\
\end{tabular}} & Wed AM & & & & & 0.721 & 0.228 & 0.714 & 0.414 \\
\hline & Wed PM & & & & & 0.821 & 0.260 & 1.077 & 0.799 \\
\hline & Thurs AM & & & & & 0.707 & 0.223 & 0.769 & 0.686 \\
\hline & Thurs PM & & & & & 0.856 & 0.271 & 0.867 & 0.624 \\
\hline MOCS01(01) & Wed AM & & & & & & & 0.200 & 0.288 \\
\hline & Wed PM & & & & & & & 0.273 & 0.267 \\
\hline & Thurs AM & & & & & & & 0.211 & 0.380 \\
\hline & Thurs PM & & & & & & & 0.200 & 0.288 \\
\hline MOCS05(01) & Wed AM & & & & & 0.329 & 0.104 & 0.333 & 0.497 \\
\hline & Wed PM & & & & & 0.353 & 0.112 & 0.230 & 0.363 \\
\hline & Thurs AM & & & & & 0.220 & 0.070 & 0.250 & 0.364 \\
\hline & Thurs PM & & & & & 0.026 & 0.008 & 0.214 & 0.258 \\
\hline NCDW02(01) & Wed AM & & & & & 0.934 & 0.295 & 0.800 & 1.207 \\
\hline & Wed PM & & & & & 0.946 & 0.299 & 0.750 & 1.105 \\
\hline & Thurs AM & & & & & 0.507 & 0.160 & 0.375 & 0.944 \\
\hline & Thurs PM & & & & & 0.829 & 0.262 & 0.667 & 1.133 \\
\hline NCDW02(02) & Wed AM & & & & & 0.867 & 0.274 & 0.800 & 1.207 \\
\hline & Wed PM & & & & & 0.819 & 0.259 & 0.750 & 1.105 \\
\hline & Thurs AM & & & & & 0.464 & 0.147 & 0.438 & 0.965 \\
\hline & Thurs PM & & & & & 0.761 & 0.241 & 0.667 & 1.133 \\
\hline NCDW03(01) & Wed AM & 185 & 391 & 55 & 117 & & & 0.288 & 0.142 \\
\hline & Wed PM & 141 & 299 & 42 & 90 & & & 0.135 & 0.193 \\
\hline & Thurs AM & 177 & 376 & 53 & 113 & & & 0.213 & 0.154 \\
\hline & Thurs PM & 178 & 378 & 54 & 113 & & & 0.179 & 0.171 \\
\hline NCDW03(02) & Wed AM & 79 & 167 & 24 & 50 & & & 0.119 & 0.170 \\
\hline & Wed PM & 76 & 162 & 23 & 49 & & & 0.213 & 0.154 \\
\hline & Thurs AM & 78 & 166 & 23 & 50 & & & 0.152 & 0.144 \\
\hline & Thurs PM & 81 & 172 & 24 & 51 & & & 0.072 & 0.205 \\
\hline NCDW03(03) & Wed AM & 12 & 25 & 4 & 8 & & & 0.000 & 0.125 \\
\hline & Wed PM & 12 & 25 & 4 & 8 & & & 0.000 & 0.222 \\
\hline & Thurs AM & 12 & 25 & 4 & 8 & & & 0.000 & 0.143 \\
\hline & Thurs PM & 12 & 25 & 4 & 8 & 0.759 & 0.291 & 0.217 & 0.629 \\
\hline
\end{tabular}




\begin{tabular}{|c|c|c|c|c|c|c|c|c|c|}
\hline \multirow[b]{2}{*}{ System ID } & \multirow[b]{2}{*}{ Day Period } & \multicolumn{2}{|c|}{ Recirculation Airflow } & \multicolumn{2}{|c|}{$\begin{array}{l}\text { Uncertainty in } \\
\text { recirc. airflow }\end{array}$} & \multirow{2}{*}{$\begin{array}{c}\text { Outdoor air } \\
\text { fraction - } \\
\text { volumetric }\end{array}$} & \multirow{2}{*}{$\begin{array}{l}\text { Uncert. in } \\
\text { vol. OA } \\
\text { fraction }\end{array}$} & \multirow{2}{*}{$\begin{array}{l}\text { OA fraction } \\
\mathrm{CO}_{2}\end{array}$} & \multirow{2}{*}{$\begin{array}{c}\text { Uncert. in } \\
\mathrm{CO}_{2} \mathrm{OA} \\
\text { fraction }\end{array}$} \\
\hline & & $\mathrm{L} / \mathrm{s}$ & $\mathrm{cfm}$ & $\mathrm{L} / \mathrm{s}$ & $\mathrm{cfm}$ & & & & \\
\hline \multirow[t]{4}{*}{ NCDW03(04) } & Wed AM & 12 & 25 & 4 & 7 & 0.862 & 0.343 & 0.000 & 3.550 \\
\hline & Wed PM & 12 & 25 & 4 & 7 & 0.858 & 0.341 & & \\
\hline & Thurs AM & 12 & 25 & 4 & 7 & 0.866 & 0.345 & & \\
\hline & Thurs PM & 12 & 25 & 4 & 7 & 0.806 & 0.314 & & \\
\hline \multirow[t]{4}{*}{ NCDW03(05) } & Wed AM & 57 & 121 & 17 & 36 & & & & \\
\hline & Wed PM & 61 & 129 & 18 & 39 & & & & \\
\hline & Thurs AM & 63 & 134 & 19 & 40 & & & 0.160 & 0.152 \\
\hline & Thurs PM & 59 & 126 & 18 & 38 & & & 0.119 & 0.170 \\
\hline \multirow[t]{4}{*}{\begin{tabular}{|l|} 
NCDW06(01) \\
\end{tabular}} & Wed AM & & & & & 0.384 & 0.121 & 0.489 & 0.350 \\
\hline & Wed PM & & & & & 0.567 & 0.179 & 0.429 & 0.550 \\
\hline & Thurs AM & & & & & 0.717 & 0.227 & 0.529 & 0.471 \\
\hline & Thurs PM & & & & & 0.369 & 0.117 & 0.333 & 0.331 \\
\hline \multirow[t]{4}{*}{ NECW01(01) } & Wed AM & & & & & 0.330 & 0.104 & 0.454 & 0.359 \\
\hline & Wed PM & & & & & 0.398 & 0.126 & 0.601 & 0.598 \\
\hline & Thurs AM & & & & & 0.357 & 0.113 & 0.475 & 0.437 \\
\hline & Thurs PM & & & & & 0.584 & 0.185 & 0.625 & 0.651 \\
\hline \multirow[t]{4}{*}{ NECW02(01) } & Wed AM & & & & & 0.789 & 0.250 & 0.700 & 1.726 \\
\hline & Wed PM & & & & & 0.566 & 0.179 & 0.667 & 1.133 \\
\hline & Thurs AM & & & & & 0.755 & 0.239 & 0.700 & 1.726 \\
\hline & Thurs PM & & & & & 0.733 & 0.232 & 0.800 & 1.811 \\
\hline \multirow[t]{4}{*}{ NECW03(01) } & Wed AM & & & & & 0.686 & 0.217 & 0.331 & 0.426 \\
\hline & Wed PM & & & & & 0.669 & 0.212 & 0.328 & 0.555 \\
\hline & Thurs AM & & & & & 0.466 & 0.147 & 0.263 & 0.385 \\
\hline & Thurs PM & & & & & 0.881 & 0.279 & 0.600 & 0.550 \\
\hline \multirow[t]{4}{*}{ NMES01(01) } & Wed AM & 1718 & 3640 & 515 & 1092 & 0.511 & 0.188 & 0.536 & 0.573 \\
\hline & Wed PM & 1252 & 2652 & 376 & 796 & 0.630 & 0.234 & 0.541 & 0.434 \\
\hline & Thurs AM & 1491 & 3159 & 447 & 948 & 0.533 & 0.196 & 0.600 & 0.471 \\
\hline & Thurs PM & 1356 & 2873 & 407 & 862 & 0.590 & 0.218 & 0.533 & 0.534 \\
\hline NMES01(02) & Wed AM & 4579 & 9702 & 1374 & 2910 & 0.184 & 0.072 & 0.324 & 0.402 \\
\hline & Wed PM & 4862 & 10301 & 1459 & 3090 & 0.173 & 0.068 & 0.194 & 0.400 \\
\hline & Thurs AM & 4271 & 9048 & 1281 & 2714 & 0.139 & 0.055 & 0.225 & 0.362 \\
\hline & Thurs PM & 4708 & 9974 & 1412 & 2992 & 0.165 & 0.065 & 0.108 & 0.384 \\
\hline NMES02(01) & Wed AM & & & & & 1.385 & 0.438 & 0.500 & 0.791 \\
\hline & Wed PM & & & & & 1.241 & 0.393 & 0.968 & 0.635 \\
\hline & Thurs AM & & & & & 1.083 & 0.343 & 0.922 & 1.503 \\
\hline & Thurs PM & & & & & 1.521 & 0.481 & 0.810 & 1.152 \\
\hline NMES03(01) & Wed AM & 3174 & 6725 & 952 & 2018 & 0.073 & 0.296 & 0.231 & 0.279 \\
\hline & Wed PM & 3032 & 6424 & 910 & 1927 & 0.133 & 0.279 & 0.250 & 0.243 \\
\hline & Thurs AM & 2802 & 5937 & 841 & 1781 & 0.102 & 0.287 & 0.130 & 0.310 \\
\hline & Thurs PM & 2988 & 6331 & 897 & 1899 & 0.019 & 0.311 & 0.083 & 0.237 \\
\hline NMES03(02) & Wed AM & 4444 & 9416 & 1333 & 2825 & 0.110 & 0.285 & 0.120 & 0.285 \\
\hline & Wed PM & 5509 & 11671 & 1653 & 3501 & 0.148 & 0.275 & 0.222 & 0.322 \\
\hline & Thurs AM & 4416 & 9355 & 1325 & 2807 & 0.193 & 0.263 & 0.240 & 0.291 \\
\hline & Thurs PM & 5126 & 10860 & 1538 & 3258 & 0.144 & 0.276 & 0.273 & 0.267 \\
\hline NVAW01(01) & Wed AM & & & & & 1.001 & 0.316 & 0.910 & 1.427 \\
\hline & Wed PM & & & & & 0.673 & 0.213 & 0.882 & 1.387 \\
\hline & Thurs AM & & & & & 0.545 & 0.172 & 0.692 & 1.323 \\
\hline & Thurs PM & & & & & 0.277 & 0.088 & 0.500 & 0.791 \\
\hline NVAW02(01) & Wed AM & 1242 & 2632 & 373 & 790 & 0.950 & 0.139 & 0.655 & 0.768 \\
\hline & Wed PM & 1210 & 2563 & 363 & 769 & 0.956 & 0.139 & 1.000 & 1.000 \\
\hline & Thurs AM & 981 & 2078 & 294 & 623 & 0.959 & 0.139 & 1.000 & 4.000 \\
\hline & Thurs PM & 1912 & 4052 & 574 & 1216 & 0.930 & 0.138 & 0.333 & 0.994 \\
\hline NVAW03(01) & Wed AM & & & & & 1.091 & 0.345 & 0.444 & 1.720 \\
\hline & Wed PM & & & & & 1.133 & 0.358 & 0.500 & 1.581 \\
\hline & Thurs AM & & & & & 1.099 & 0.348 & 0.333 & 0.994 \\
\hline & Thurs PM & & & & & 1.099 & 0.348 & 1.000 & 2.000 \\
\hline
\end{tabular}




\begin{tabular}{|c|c|c|c|c|c|c|c|c|c|}
\hline \multirow[b]{2}{*}{ System ID } & \multirow[b]{2}{*}{ Day Period } & \multicolumn{2}{|c|}{ Recirculation Airflow } & \multicolumn{2}{|c|}{$\begin{array}{l}\text { Uncertainty in } \\
\text { recirc. airflow }\end{array}$} & \multirow{2}{*}{$\begin{array}{c}\text { Outdoor air } \\
\text { fraction - } \\
\text { volumetric }\end{array}$} & \multirow{2}{*}{$\begin{array}{c}\text { Uncert. in } \\
\text { vol. OA } \\
\text { fraction }\end{array}$} & \multirow{2}{*}{$\begin{array}{l}\text { OA fraction - } \\
\mathrm{CO}_{2}\end{array}$} & \multirow{2}{*}{$\begin{array}{c}\text { Uncert. in } \\
\mathrm{CO}_{2} \mathrm{OA} \\
\text { fraction }\end{array}$} \\
\hline & & $\mathrm{L} / \mathrm{s}$ & $\mathrm{cfm}$ & $\mathrm{L} / \mathrm{s}$ & $\mathrm{cfm}$ & & & & \\
\hline \multirow[t]{4}{*}{\begin{tabular}{|l|} 
NVAW03(02) \\
\end{tabular}} & Wed AM & & & & & 0.488 & 0.154 & 0.444 & 1.720 \\
\hline & Wed PM & & & & & 0.503 & 0.159 & 0.700 & 1.726 \\
\hline & Thurs AM & & & & & 0.513 & 0.162 & 0.500 & 0.791 \\
\hline & Thurs PM & & & & & 0.498 & 0.157 & 0.000 & 2.840 \\
\hline \multirow[t]{4}{*}{\begin{tabular}{|l|} 
NYBS01(01) \\
\end{tabular}} & Wed AM & 26968 & 57134 & 8090 & 17140 & 0.147 & 0.275 & 0.167 & 0.597 \\
\hline & Wed PM & 29021 & 61484 & 8706 & 18445 & 0.118 & 0.283 & 0.214 & 0.517 \\
\hline & Thurs AM & 28473 & 60324 & 8542 & 18097 & 0.109 & 0.286 & 0.241 & 0.502 \\
\hline & Thurs PM & 28473 & 60324 & 8542 & 18097 & 0.127 & 0.281 & 0.080 & 0.567 \\
\hline \multirow[t]{4}{*}{ NYBS01(02) } & Wed AM & & & & & 0.147 & 0.047 & 0.308 & 0.569 \\
\hline & Wed PM & & & & & 0.149 & 0.047 & 0.133 & 0.476 \\
\hline & Thurs AM & & & & & 0.143 & 0.045 & 0.267 & 0.488 \\
\hline & Thurs PM & & & & & 0.154 & 0.049 & 0.429 & 0.440 \\
\hline \multirow[t]{4}{*}{ NYBS02(01) } & Wed AM & & & & & 0.100 & 0.032 & 0.115 & 0.583 \\
\hline & Wed PM & & & & & 0.096 & 0.030 & 0.513 & 0.668 \\
\hline & Thurs AM & & & & & 0.074 & 0.023 & 0.238 & 0.433 \\
\hline & Thurs PM & & & & & 0.136 & 0.043 & 0.368 & 0.331 \\
\hline \multirow[t]{4}{*}{\begin{tabular}{|l|} 
NYBS02(02) \\
\end{tabular}} & Wed AM & & & & & 0.090 & 0.029 & 0.714 & 1.241 \\
\hline & Wed PM & & & & & 0.126 & 0.040 & 0.615 & 0.639 \\
\hline & Thurs AM & & & & & 0.117 & 0.037 & 0.441 & 0.655 \\
\hline & Thurs PM & & & & & 0.163 & 0.052 & 0.494 & 0.512 \\
\hline NYBS04(01) & Wed AM & & & & & 0.014 & 0.004 & 0.000 & 0.473 \\
\hline & Wed PM & & & & & 0.013 & 0.004 & 0.077 & 0.273 \\
\hline & Thurs AM & & & & & 0.766 & 0.242 & 0.444 & 0.860 \\
\hline & Thurs PM & & & & & 0.011 & 0.004 & 0.154 & 0.550 \\
\hline NYBS04(02) & Wed AM & & & & & 0.037 & 0.012 & 0.000 & 0.473 \\
\hline & Wed PM & & & & & 0.035 & 0.011 & 0.040 & 0.283 \\
\hline & Thurs AM & & & & & 0.912 & 0.288 & 0.400 & 0.762 \\
\hline & Thurs PM & & & & & 0.035 & 0.011 & 0.086 & 0.406 \\
\hline NYBS05(01) & Wed AM & & & & & 0.255 & 0.081 & 0.326 & 0.216 \\
\hline & Wed PM & & & & & 0.238 & 0.075 & 0.208 & 0.234 \\
\hline & Thurs AM & & & & & 0.247 & 0.078 & 0.270 & 0.225 \\
\hline & Thurs PM & & & & & 0.227 & 0.072 & 0.328 & 0.188 \\
\hline NYBS07(01) & Wed AM & 4062 & 8606 & 1219 & 2582 & 0.199 & 0.077 & 0.400 & 0.762 \\
\hline & Wed PM & 4253 & 9010 & 1276 & 2703 & 0.199 & 0.077 & 0.432 & 0.416 \\
\hline & Thurs AM & 4157 & 8808 & 1247 & 2642 & 0.205 & 0.080 & 0.364 & 0.684 \\
\hline & Thurs PM & 4005 & 8485 & 1201 & 2545 & 0.200 & 0.078 & 0.063 & 0.443 \\
\hline ORIS03(01) & Wed AM & & & & & 0.448 & 0.144 & 0.364 & 0.684 \\
\hline & Wed PM & & & & & 0.417 & 0.134 & 0.174 & 0.624 \\
\hline & Thurs AM & & & & & 0.451 & 0.145 & 0.295 & 0.604 \\
\hline & Thurs PM & & & & & 0.466 & 0.150 & 0.286 & 0.525 \\
\hline ORIS03(03) & Wed AM & & & & & & & 0.364 & 0.684 \\
\hline & Wed PM & & & & & & & 0.240 & 0.582 \\
\hline & Thurs AM & & & & & & & 0.348 & 0.567 \\
\hline & Thurs PM & & & & & & & 0.214 & 0.517 \\
\hline ORIS04(01) & Wed AM & & & & & & & 0.833 & 1.534 \\
\hline & Wed PM & & & & & & & 0.667 & 1.416 \\
\hline & Thurs AM & & & & & & & 0.800 & 1.811 \\
\hline & Thurs PM & & & & & & & 0.167 & 1.195 \\
\hline PABS03(01) & Wed AM & 16550 & 35064 & 4965 & 10519 & 0.000 & 0.328 & 0.205 & 0.328 \\
\hline & Wed PM & 16360 & 34661 & 4908 & 10398 & 0.000 & 0.348 & 0.000 & 0.374 \\
\hline & Thurs AM & 17977 & 38087 & 5393 & 11426 & 0.000 & 0.374 & 0.091 & 0.323 \\
\hline & Thurs PM & 18929 & 40102 & 5679 & 12031 & 0.000 & 0.363 & 0.053 & 0.373 \\
\hline PABS04(01) & Wed AM & & & & & 0.197 & 0.062 & 0.125 & 0.165 \\
\hline & Wed PM & & & & & 0.193 & 0.061 & 0.215 & 0.159 \\
\hline & Thurs AM & & & & & 0.195 & 0.062 & 0.214 & 0.207 \\
\hline & Thurs PM & & & & & 0.200 & 0.063 & 0.188 & 0.180 \\
\hline PABS04(02) & Wed AM & & & & & 0.038 & 0.012 & 0.045 & 0.167 \\
\hline & Wed PM & & & & & 0.038 & 0.012 & 0.047 & 0.157 \\
\hline & Thurs AM & & & & & 0.035 & 0.011 & 0.096 & 0.208 \\
\hline & Thurs PM & & & & & 0.035 & 0.011 & 0.063 & 0.177 \\
\hline
\end{tabular}




\begin{tabular}{|c|c|c|c|c|c|c|c|c|c|}
\hline \multirow[b]{2}{*}{ System ID } & \multirow[b]{2}{*}{ Day Period } & \multicolumn{2}{|c|}{ Recirculation Airflow } & \multicolumn{2}{|c|}{$\begin{array}{l}\text { Uncertainty in } \\
\text { recirc. airflow }\end{array}$} & \multirow{2}{*}{$\begin{array}{c}\text { Outdoor air } \\
\text { fraction - } \\
\text { volumetric }\end{array}$} & \multirow{2}{*}{$\begin{array}{c}\text { Uncert. in } \\
\text { vol. OA } \\
\text { fraction }\end{array}$} & \multirow{2}{*}{$\begin{array}{c}\text { OA fraction } \\
\mathrm{CO}_{2}\end{array}$} & \multirow{2}{*}{$\begin{array}{c}\text { Uncert. in } \\
\mathrm{CO}_{2} \mathrm{OA} \\
\text { fraction }\end{array}$} \\
\hline & & $\mathrm{L} / \mathrm{s}$ & $\mathrm{cfm}$ & $\mathrm{L} / \mathrm{s}$ & $\mathrm{cfm}$ & & & & \\
\hline \multirow[t]{4}{*}{ SCDW01(01) } & Wed AM & & & & & 0.241 & 0.076 & 0.212 & 0.222 \\
\hline & Wed PM & & & & & 0.249 & 0.079 & & \\
\hline & Thurs AM & & & & & 0.238 & 0.075 & 0.203 & 0.144 \\
\hline & Thurs PM & & & & & 0.220 & 0.070 & 0.185 & 0.155 \\
\hline \multirow[t]{4}{*}{ SCDW02(01) } & Wed AM & & & & & 0.182 & 0.057 & 0.286 & 0.420 \\
\hline & Wed PM & & & & & 0.187 & 0.059 & 0.250 & 0.364 \\
\hline & Thurs AM & & & & & 0.191 & 0.060 & 0.286 & 0.420 \\
\hline & Thurs PM & & & & & 0.155 & 0.049 & 0.500 & 0.527 \\
\hline \multirow[t]{4}{*}{ SDBW01(01) } & Wed AM & & & & & 0.456 & 0.144 & 0.385 & 0.389 \\
\hline & Wed PM & & & & & 0.517 & 0.163 & 0.471 & 0.460 \\
\hline & Thurs AM & & & & & 0.523 & 0.165 & 0.325 & 0.372 \\
\hline & Thurs PM & & & & & 0.546 & 0.173 & 0.455 & 0.471 \\
\hline \multirow[t]{4}{*}{ SDBW02(01) } & Wed AM & & & & & 0.444 & 0.140 & 0.444 & 0.344 \\
\hline & Wed PM & & & & & 0.293 & 0.093 & 0.444 & 0.344 \\
\hline & Thurs AM & & & & & 0.283 & 0.090 & 0.333 & 0.497 \\
\hline & Thurs PM & & & & & 0.236 & 0.074 & 0.250 & 0.364 \\
\hline \multirow[t]{4}{*}{ SDBW04(01) } & Wed AM & 9318 & 19742 & 2795 & 5922 & 0.214 & 0.257 & 0.094 & 0.444 \\
\hline & Wed PM & 8062 & 17081 & 2419 & 5124 & 0.199 & 0.261 & 0.115 & 0.548 \\
\hline & Thurs AM & 7798 & 16521 & 2339 & 4956 & 0.195 & 0.262 & 0.140 & 0.499 \\
\hline & Thurs PM & 7534 & 15961 & 2260 & 4788 & 0.216 & 0.256 & 0.167 & 0.478 \\
\hline \multirow[t]{4}{*}{\begin{tabular}{|l|} 
TNDS05(01) \\
\end{tabular}} & Wed AM & & & & & 1.000 & 0.316 & & \\
\hline & Wed PM & & & & & 1.000 & 0.316 & & \\
\hline & Thurs AM & & & & & 1.000 & 0.316 & & \\
\hline & Thurs PM & & & & & 1.000 & 0.316 & & \\
\hline \multirow[t]{4}{*}{\begin{tabular}{|l|} 
TNDS05(02) \\
\end{tabular}} & Wed AM & & & & & 1.000 & 0.316 & & \\
\hline & Wed PM & & & & & 1.000 & 0.316 & & \\
\hline & Thurs AM & & & & & 1.000 & 0.316 & & \\
\hline & Thurs PM & & & & & 1.000 & 0.316 & & \\
\hline TNDS06(01) & Wed AM & 67909 & 143871 & 20373 & 43161 & 0.213 & 0.257 & 0.276 & 0.343 \\
\hline & Wed PM & 67403 & 142799 & 20221 & 42840 & 0.086 & 0.292 & 0.335 & 0.284 \\
\hline & Thurs AM & 58901 & 124788 & 17670 & 37437 & 0.130 & 0.280 & 0.208 & 0.301 \\
\hline & Thurs PM & 68010 & 144087 & 20403 & 43226 & 0.022 & 0.310 & 0.222 & 0.322 \\
\hline TNDS07(01) & Wed AM & & & & & 0.024 & 0.008 & 0.000 & 0.710 \\
\hline & Wed PM & & & & & 0.030 & 0.009 & 0.200 & 0.577 \\
\hline & Thurs AM & & & & & 0.030 & 0.010 & 0.000 & 0.568 \\
\hline & Thurs PM & & & & & 0.159 & 0.050 & 0.000 & 0.710 \\
\hline TNFS08(01) & Wed AM & & & & & 0.204 & 0.064 & 0.196 & 0.160 \\
\hline & Wed PM & & & & & 0.245 & 0.077 & 0.205 & 0.168 \\
\hline & Thurs AM & & & & & 0.229 & 0.072 & 0.200 & 0.176 \\
\hline & Thurs PM & & & & & 0.180 & 0.057 & 0.176 & 0.191 \\
\hline TNFS085(02) & Wed AM & 977 & 2070 & 293 & 621 & 0.269 & 0.102 & 0.412 & 0.197 \\
\hline & Wed PM & 1051 & 2227 & 315 & 668 & 0.222 & 0.086 & 0.231 & 0.186 \\
\hline & Thurs AM & 1056 & 2236 & 317 & 671 & 0.226 & 0.087 & 0.202 & 0.221 \\
\hline & Thurs PM & 1019 & 2160 & 306 & 648 & 0.225 & 0.087 & 0.211 & 0.206 \\
\hline TNFS09(01) & Wed AM & 4319 & 9150 & 1296 & 2745 & 0.369 & 0.217 & 0.200 & 0.288 \\
\hline & Wed PM & 4259 & 9024 & 1278 & 2707 & 0.323 & 0.229 & 0.185 & 0.266 \\
\hline & Thurs AM & 4289 & 9087 & 1287 & 2726 & 0.272 & 0.242 & 0.231 & 0.279 \\
\hline & Thurs PM & 4170 & 8835 & 1251 & 2650 & 0.297 & 0.235 & 0.200 & 0.180 \\
\hline TNFS09(02) & Wed AM & & & & & 0.076 & 0.024 & 0.165 & 0.181 \\
\hline & Wed PM & & & & & 0.071 & 0.022 & 0.000 & 0.151 \\
\hline & Thurs AM & & & & & 0.053 & 0.017 & 0.056 & 0.157 \\
\hline & Thurs PM & & & & & 0.057 & 0.018 & 0.050 & 0.142 \\
\hline TNFS10(01) & Wed AM & 3326 & 7047 & 998 & 2114 & 0.688 & 0.153 & 0.634 & 0.681 \\
\hline & Wed PM & 5837 & 12367 & 1751 & 3710 & 0.535 & 0.180 & 0.444 & 0.860 \\
\hline & Thurs AM & 3518 & 7452 & 1055 & 2236 & 0.703 & 0.151 & 0.603 & 0.565 \\
\hline & Thurs PM & 3084 & 6534 & 925 & 1960 & 0.705 & 0.151 & 0.529 & 0.941 \\
\hline
\end{tabular}




\begin{tabular}{|c|c|c|c|c|c|c|c|c|c|}
\hline \multirow[b]{2}{*}{ System ID } & \multirow[b]{2}{*}{ Day Period } & \multicolumn{2}{|c|}{ Recirculation Airflow } & \multicolumn{2}{|c|}{$\begin{array}{l}\text { Uncertainty in } \\
\text { recirc. airflow }\end{array}$} & \multirow{2}{*}{$\begin{array}{c}\text { Outdoor air } \\
\text { fraction - } \\
\text { volumetric }\end{array}$} & \multirow{2}{*}{$\begin{array}{l}\text { Uncert. in } \\
\text { vol. OA } \\
\text { fraction }\end{array}$} & \multirow{2}{*}{$\begin{array}{l}\text { OA fraction } \\
\mathrm{CO}_{2}\end{array}$} & \multirow{2}{*}{$\begin{array}{c}\text { Uncert. in } \\
\mathrm{CO}_{2} \mathrm{OA} \\
\text { fraction }\end{array}$} \\
\hline & & $\mathrm{L} / \mathrm{s}$ & $\mathrm{cfm}$ & $\mathrm{L} / \mathrm{s}$ & $\mathrm{cfm}$ & & & & \\
\hline \multirow[t]{4}{*}{ TXFS01(01) } & Wed AM & & & & & & & 0.061 & 0.173 \\
\hline & Wed PM & & & & & 0.045 & 0.014 & 0.058 & 0.131 \\
\hline & Thurs AM & & & & & 0.043 & 0.014 & 0.071 & 0.204 \\
\hline & Thurs PM & & & & & 0.040 & 0.013 & 0.059 & 0.139 \\
\hline \multirow[t]{4}{*}{ TXFS02(01) } & Wed AM & & & & & 0.047 & 0.015 & 0.050 & 0.177 \\
\hline & Wed PM & & & & & 0.050 & 0.016 & 0.000 & 0.167 \\
\hline & Thurs AM & & & & & 0.036 & 0.011 & 0.000 & 0.215 \\
\hline & Thurs PM & & & & & 0.049 & 0.015 & 0.000 & 0.151 \\
\hline \multirow[t]{4}{*}{ TXFS02(02) } & Wed AM & & & & & 0.047 & 0.015 & 0.040 & 0.189 \\
\hline & Wed PM & & & & & 0.046 & 0.015 & 0.000 & 0.189 \\
\hline & Thurs AM & & & & & 0.043 & 0.014 & 0.000 & 0.237 \\
\hline & Thurs PM & & & & & 0.044 & 0.014 & 0.021 & 0.150 \\
\hline \multirow[t]{4}{*}{ TXFS07(01) } & Wed AM & & & & & 0.128 & 0.040 & 0.119 & 0.327 \\
\hline & Wed PM & & & & & 0.142 & 0.045 & 0.240 & 0.291 \\
\hline & Thurs AM & & & & & 0.142 & 0.045 & 0.214 & 0.258 \\
\hline & Thurs PM & & & & & 0.159 & 0.050 & 0.182 & 0.327 \\
\hline \multirow[t]{4}{*}{ TXFS08(01) } & Wed AM & & & & & 0.046 & 0.015 & 0.053 & 0.149 \\
\hline & Wed PM & & & & & 0.049 & 0.015 & 0.053 & 0.149 \\
\hline & Thurs AM & & & & & 0.058 & 0.018 & 0.063 & 0.177 \\
\hline & Thurs PM & & & & & 0.059 & 0.019 & 0.080 & 0.113 \\
\hline \multirow[t]{4}{*}{ TXFS08(02) } & Wed AM & & & & & 0.053 & 0.017 & 0.100 & 0.142 \\
\hline & Wed PM & & & & & 0.047 & 0.015 & 0.091 & 0.129 \\
\hline & Thurs AM & & & & & 0.052 & 0.017 & 0.056 & 0.157 \\
\hline & Thurs PM & & & & & 0.049 & 0.016 & 0.091 & 0.129 \\
\hline \multirow[t]{4}{*}{ TXFS09(01) } & Wed AM & & & & & 0.192 & 0.061 & 0.143 & 0.204 \\
\hline & Wed PM & & & & & 0.183 & 0.058 & 0.200 & 0.096 \\
\hline & Thurs AM & & & & & 0.188 & 0.060 & 0.125 & 0.178 \\
\hline & Thurs PM & & & & & 0.193 & 0.061 & 0.167 & 0.119 \\
\hline \multirow[t]{4}{*}{ TXFS09(02) } & Wed AM & & & & & 0.189 & 0.060 & 0.143 & 0.204 \\
\hline & Wed PM & & & & & 0.180 & 0.057 & 0.192 & 0.111 \\
\hline & Thurs AM & & & & & 0.194 & 0.061 & 0.125 & 0.178 \\
\hline & Thurs PM & & & & & 0.195 & 0.062 & 0.083 & 0.118 \\
\hline \multirow[t]{4}{*}{\begin{tabular}{|l} 
TXFW05(01) \\
\end{tabular}} & Wed AM & 26244 & 55602 & 7873 & 16680 & 0.259 & 0.245 & 0.516 & 0.652 \\
\hline & Wed PM & 25650 & 54343 & 7695 & 16303 & 0.248 & 0.248 & 0.400 & 0.609 \\
\hline & Thurs AM & 17274 & 36598 & 5182 & 10979 & 0.586 & 0.170 & 0.161 & 0.462 \\
\hline & Thurs PM & 15762 & 33393 & 4729 & 10018 & 0.623 & 0.163 & 0.333 & 0.497 \\
\hline \multirow[t]{4}{*}{ TXFW06(01) } & Wed AM & & & & & 1.004 & 0.318 & 0.667 & 1.133 \\
\hline & Wed PM & & & & & 1.000 & 0.316 & 1.000 & 1.333 \\
\hline & Thurs AM & & & & & 1.001 & 0.317 & 0.800 & 0.724 \\
\hline & Thurs PM & & & & & 1.002 & 0.317 & 0.800 & 0.724 \\
\hline \multirow[t]{4}{*}{\begin{tabular}{|l} 
WAIW03(01) \\
\end{tabular}} & Wed AM & & & & & 1.010 & 0.319 & 0.789 & 0.474 \\
\hline & Wed PM & & & & & 0.886 & 0.280 & 0.938 & 0.606 \\
\hline & Thurs AM & & & & & 1.018 & 0.322 & 0.905 & 0.908 \\
\hline & Thurs PM & & & & & 0.920 & 0.291 & 0.929 & 0.689 \\
\hline WAIW04(01) & Wed AM & & & & & 0.973 & 0.308 & 0.600 & 0.660 \\
\hline & Wed PM & & & & & 0.990 & 0.313 & 0.833 & 0.614 \\
\hline & Thurs AM & & & & & 0.982 & 0.310 & 0.500 & 0.527 \\
\hline & Thurs PM & & & & & 1.003 & 0.317 & 0.571 & 0.465 \\
\hline
\end{tabular}

\begin{tabular}{|l|c|c|c|c|c|c|c|c|}
\hline \# of values & 186 & & & & 509 & & 520 & \\
\hline Mean & 7930 & 16800 & 2379 & 5040 & 0.377 & 0.158 & 0.311 & 0.601 \\
\hline StdDev & 11304 & 23948 & 3391 & 7185 & 0.350 & 0.120 & 0.270 & 0.625 \\
\hline Minimum & 12 & 25 & 4 & 7 & 0.000 & 0.004 & 0.000 & 0.096 \\
\hline 10th percentile & 181 & 384 & 54 & 115 & 0.043 & 0.017 & 0.030 & 0.159 \\
\hline 25th percentile & 1508 & 3196 & 453 & 959 & 0.104 & 0.047 & 0.110 & 0.237 \\
\hline Median & 4357 & 9230 & 1307 & 2769 & 0.222 & 0.144 & 0.231 & 0.433 \\
\hline 75th percentile & 9139 & 19361 & 2742 & 5808 & 0.594 & 0.275 & 0.444 & 0.711 \\
\hline 90th percentile & 18414 & 39012 & 5524 & 11703 & 1.000 & 0.316 & 0.750 & 1.133 \\
\hline Maximum & 68010 & 144087 & 20403 & 43226 & 1.521 & 0.481 & 1.200 & 7.100 \\
\hline
\end{tabular}




\section{Appendix E: Measured Data for Study Spaces}

This appendix presents the following information for the measurements in the study spaces:

Study space ID

Day and time of measurement

Supply airflow per unit floor area and associated uncertainty

Outdoor airflow per person, per unit floor area and in air changes per hour based on volumetric airflow measurements (VOL), and associated uncertainties

Outdoor airflow per person, per unit floor area and in air changes per hour based on volumetric supply airflow times $\mathrm{CO}_{2}$-based outdoor air fraction (RATIO), and associated uncertainties

Outdoor airflow rate per person based on peak $\mathrm{CO}_{2}$ analysis (PEAK), and associated uncertainties

Changes in the table relative to the original 2004 report are highlighted in yellow. 


\begin{tabular}{|c|c|c|c|c|c|c|c|c|c|c|c|c|c|c|c|}
\hline \multirow{3}{*}{$\begin{array}{l}\text { Study Space } \\
\text { ID }\end{array}$} & \multirow[b]{3}{*}{ Period } & \multicolumn{4}{|c|}{ SUPPLY AIRFLOW } & \multicolumn{10}{|c|}{ OUTDOOR AIRFLOW } \\
\hline & & \multicolumn{2}{|c|}{$\begin{array}{c}\text { Volumetric supply } \\
\text { airflow }\end{array}$} & \multicolumn{2}{|c|}{$\begin{array}{l}\text { Uncertainty in } \\
\text { supply airflow }\end{array}$} & \multicolumn{5}{|c|}{ Volumetric } & \multicolumn{5}{|c|}{ Uncertainty in volumetric $\mathrm{OA}$} \\
\hline & & $\mathrm{L} / \mathrm{s} \cdot \mathrm{m}^{2}$ & $\mathrm{cfm} / \mathrm{ft}^{2}$ & $\mathrm{~L} / \mathrm{s} \cdot \mathrm{m}^{2}$ & $\mathrm{cfm} / \mathrm{ft}^{2}$ & $L / s \cdot$ person & $\mathrm{cfm} /$ person & $\mathrm{L} / \mathrm{s} \cdot \mathrm{m}^{2}$ & $\mathrm{cfm} / \mathrm{ft}^{2}$ & $h^{-1}$ & $L / s \cdot$ person & cfm/person & $\mathrm{L} / \mathrm{s} \cdot \mathrm{m}^{2}$ & $\mathrm{cfm} / \mathrm{ft}^{2}$ & $\mathrm{~h}^{-1}$ \\
\hline \multirow[t]{4}{*}{ ARFW01 } & Wed AM & 8.36 & 1.65 & 1.02 & 0.20 & 10.3 & 21.9 & 0.46 & 0.09 & 0.44 & 2.4 & 5.1 & 0.11 & 0.02 & 0.13 \\
\hline & Wed PM & 8.29 & 1.63 & 1.02 & 0.20 & 14.8 & 31.4 & 0.45 & 0.09 & 0.42 & 3.5 & 7.4 & 0.11 & 0.02 & 0.12 \\
\hline & Thur AM & 8.24 & 1.62 & 1.01 & 0.20 & 12.1 & 25.5 & 0.47 & 0.09 & 0.45 & 2.8 & 6.0 & 0.11 & 0.02 & 0.13 \\
\hline & Thur PM & 8.37 & 1.65 & 1.02 & 0.20 & 12.6 & 26.7 & 0.45 & 0.09 & 0.43 & 3.0 & 6.3 & 0.11 & 0.02 & 0.12 \\
\hline \multirow[t]{4}{*}{ ARFW02 } & Wed AM & 2.41 & 0.47 & 0.34 & 0.07 & & & & & & & & & & \\
\hline & Wed PM & 2.32 & 0.46 & 0.33 & 0.06 & 112.7 & 238.7 & 1.88 & 0.37 & 1.51 & 27.6 & 58.5 & 0.46 & 0.09 & 0.45 \\
\hline & Thur AM & & & & & & & & & & & & & & \\
\hline & Thur PM & 2.33 & 0.46 & 0.33 & 0.06 & 81.2 & 172.1 & 1.94 & 0.38 & 1.54 & 19.9 & 42.2 & 0.48 & 0.09 & 0.46 \\
\hline \multirow[t]{4}{*}{ ARFW03 } & Wed AM & 5.04 & 0.99 & 0.62 & 0.12 & 7.6 & 16.2 & 0.34 & 0.07 & 0.27 & 1.8 & 3.9 & 0.08 & 0.02 & 0.08 \\
\hline & Wed PM & 5.46 & 1.08 & 0.68 & 0.13 & 8.1 & 17.1 & 0.32 & 0.06 & 0.25 & 2.1 & 4.4 & 0.08 & 0.02 & 0.08 \\
\hline & Thur AM & 5.42 & 1.07 & 0.67 & 0.13 & 7.1 & 15.1 & 0.36 & 0.07 & 0.29 & 1.8 & 3.9 & 0.09 & 0.02 & 0.09 \\
\hline & Thur PM & 5.35 & 1.05 & 0.66 & 0.13 & 7.9 & 16.8 & 0.34 & 0.07 & 0.27 & 2.0 & 4.3 & 0.09 & 0.02 & 0.08 \\
\hline \multirow[t]{4}{*}{ AZHS02 } & Wed AM & 6.18 & 1.22 & 0.77 & 0.15 & 45.9 & 97.3 & 2.47 & 0.49 & 2.43 & 18.3 & 38.7 & 0.98 & 0.19 & 1.05 \\
\hline & Wed PM & 6.83 & 1.34 & 0.85 & 0.17 & 128.0 & 271.2 & 3.33 & 0.66 & 3.28 & 38.4 & 81.4 & 1.00 & 0.20 & 1.14 \\
\hline & Thur AM & 5.44 & 1.07 & 0.68 & 0.13 & 24.8 & 52.6 & 1.55 & 0.31 & 1.53 & 15.6 & 33.0 & 0.97 & 0.19 & 0.99 \\
\hline & Thur PM & 5.97 & 1.17 & 0.74 & 0.15 & 33.6 & 71.2 & 2.01 & 0.40 & 1.98 & 16.4 & 34.8 & 0.98 & 0.19 & 1.03 \\
\hline \multirow[t]{4}{*}{ AZHS04 } & Wed AM & 6.25 & 1.23 & 0.86 & 0.17 & 0.8 & 1.6 & 0.06 & 0.01 & 0.06 & 25.6 & 54.3 & 2.54 & 0.50 & 1.91 \\
\hline & Wed PM & 6.21 & 1.22 & 0.86 & 0.17 & 1.8 & 3.9 & 0.06 & 0.01 & 0.06 & 58.0 & 122.9 & 2.64 & 0.52 & 1.97 \\
\hline & Thur AM & 6.13 & 1.21 & 0.85 & 0.17 & 1.9 & 4.0 & 0.04 & 0.01 & 0.05 & 71.5 & 151.5 & 2.29 & 0.45 & 1.69 \\
\hline & Thur PM & 5.96 & 1.17 & 0.82 & 0.16 & 2.3 & 4.9 & 0.07 & 0.01 & 0.07 & 65.5 & 138.7 & 2.59 & 0.51 & 1.92 \\
\hline \multirow[t]{4}{*}{ AZHW10 } & Wed AM & 5.72 & 1.13 & 0.86 & 0.17 & 199.5 & 422.7 & 5.72 & 1.13 & 6.15 & 30.1 & 63.8 & 0.86 & 0.17 & 1.41 \\
\hline & Wed PM & 5.56 & 1.09 & 0.83 & 0.16 & 247.3 & 523.8 & 5.56 & 1.09 & 5.97 & 37.1 & 78.5 & 0.83 & 0.16 & 1.37 \\
\hline & Thur AM & 6.21 & 1.22 & 0.94 & 0.18 & 228.7 & 484.6 & 6.21 & 1.22 & 6.67 & 34.6 & 73.3 & 0.94 & 0.18 & 1.53 \\
\hline & Thur PM & 6.25 & 1.23 & 0.95 & 0.19 & 230.2 & 487.7 & 6.25 & 1.23 & 6.71 & 34.9 & 74.0 & 0.95 & 0.19 & 1.55 \\
\hline \multirow[t]{4}{*}{ AZHW11 } & Wed AM & 5.26 & 1.03 & 0.91 & 0.18 & 25.1 & 53.1 & 1.00 & 0.20 & 0.98 & 34.7 & 73.6 & 1.39 & 0.27 & 1.37 \\
\hline & Wed PM & 6.20 & 1.22 & 1.07 & 0.21 & 57.2 & 121.1 & 1.82 & 0.36 & 1.78 & 46.3 & 98.2 & 1.47 & 0.29 & 1.47 \\
\hline & Thur AM & 6.12 & 1.20 & 1.06 & 0.21 & 60.1 & 127.4 & 2.05 & 0.40 & 2.00 & 41.0 & 86.9 & 1.40 & 0.27 & 1.41 \\
\hline & Thur PM & 6.70 & 1.32 & 1.16 & 0.23 & 75.7 & 160.3 & 2.30 & 0.45 & 2.25 & 50.0 & 106.0 & 1.52 & 0.30 & 1.53 \\
\hline \multirow[t]{4}{*}{ AZHW12 } & Wed AM & 1.40 & 0.28 & 0.20 & 0.04 & 10.7 & 22.7 & 0.38 & 0.08 & 0.37 & 2.9 & 6.1 & 0.10 & 0.02 & 0.12 \\
\hline & Wed PM & 1.39 & 0.27 & 0.20 & 0.04 & 12.6 & 26.7 & 0.40 & 0.08 & 0.39 & 3.3 & 7.1 & 0.11 & 0.02 & 0.12 \\
\hline & Thur AM & 1.35 & 0.27 & 0.20 & 0.04 & 9.6 & 20.3 & 0.31 & 0.06 & 0.30 & 3.0 & 6.4 & 0.10 & 0.02 & 0.11 \\
\hline & Thur PM & 1.42 & 0.28 & 0.21 & 0.04 & 11.1 & 23.6 & 0.33 & 0.06 & 0.32 & 3.6 & 7.5 & 0.11 & 0.02 & 0.12 \\
\hline \multirow[t]{4}{*}{ CAES17 } & Wed AM & 19.59 & 3.86 & 2.77 & 0.55 & 64.7 & 137.0 & 3.66 & 0.72 & 3.60 & 91.6 & 194.1 & 5.18 & 1.02 & 5.13 \\
\hline & Wed PM & 18.72 & 3.68 & 2.65 & 0.52 & 50.2 & 106.4 & 2.66 & 0.52 & 2.61 & 97.8 & 207.2 & 5.18 & 1.02 & 5.11 \\
\hline & Thur AM & 21.11 & 4.15 & 2.99 & 0.59 & 235.6 & 499.1 & 11.90 & 2.34 & 11.71 & 72.7 & 154.1 & 3.67 & 0.72 & 4.14 \\
\hline & Thur PM & 20.13 & 3.96 & 2.85 & 0.56 & 113.8 & 241.0 & 6.16 & 1.21 & 6.06 & 86.7 & 183.6 & 4.69 & 0.92 & 4.73 \\
\hline \multirow[t]{4}{*}{ CAEW07 } & Wed AM & 5.28 & 1.04 & 0.91 & 0.18 & 57.2 & 121.2 & 1.62 & 0.32 & 1.44 & 19.0 & 40.2 & 0.54 & 0.11 & 0.54 \\
\hline & Wed PM & 5.60 & 1.10 & 0.97 & 0.19 & 161.3 & 341.8 & 4.86 & 0.96 & 4.33 & 53.5 & 113.4 & 1.61 & 0.32 & 1.62 \\
\hline & Thur AM & 5.28 & 1.04 & 0.91 & 0.18 & 155.9 & 330.3 & 4.03 & 0.79 & 3.59 & 51.7 & 109.6 & 1.34 & 0.26 & 1.34 \\
\hline & Thur PM & 5.20 & 1.02 & 0.90 & 0.18 & 180.9 & 383.3 & 5.45 & 1.07 & 4.86 & 60.0 & 127.1 & 1.81 & 0.36 & 1.82 \\
\hline
\end{tabular}




\begin{tabular}{|c|c|c|c|c|c|c|c|c|c|c|c|c|c|c|c|}
\hline \multirow{3}{*}{$\begin{array}{l}\text { Study Space } \\
\text { ID }\end{array}$} & \multirow[b]{3}{*}{ Period } & \multicolumn{4}{|c|}{ SUPPLY AIRFLOW } & \multicolumn{10}{|c|}{ OUTDOOR AIRFLOW } \\
\hline & & \multicolumn{2}{|c|}{$\begin{array}{c}\text { Volumetric supply } \\
\text { airflow }\end{array}$} & \multicolumn{2}{|c|}{$\begin{array}{l}\text { Uncertainty in } \\
\text { supply airflow }\end{array}$} & \multicolumn{5}{|c|}{ Volumetric } & \multicolumn{5}{|c|}{ Uncertainty in volumetric $\mathrm{OA}$} \\
\hline & & $\mathrm{L} / \mathrm{s} \cdot \mathrm{m}^{2}$ & $\mathrm{cfm} / \mathrm{ft}^{2}$ & $\mathrm{~L} / \mathrm{s} \cdot \mathrm{m}^{2}$ & $\mathrm{cfm} / \mathrm{ft}^{2}$ & $\mathrm{~L} / \mathrm{s} \bullet$ person & $\mathrm{cfm} /$ person & $\mathrm{L} / \mathrm{s} \cdot \mathrm{m}^{2}$ & $\mathrm{cfm} / \mathrm{ft}^{2}$ & $\mathrm{~h}^{-1}$ & L/s•person & $\mathrm{cfm} /$ person & $\mathrm{L} / \mathrm{s} \cdot \mathrm{m}^{2}$ & $\mathrm{cfm} / \mathrm{ft}^{2}$ & $\mathrm{~h}^{-1}$ \\
\hline \multirow[t]{4}{*}{ CAEW09 } & Wed AM & 1.82 & 0.36 & 0.26 & 0.05 & 38.2 & 80.9 & 0.58 & 0.11 & 0.51 & 12.1 & 25.6 & 0.18 & 0.04 & 0.18 \\
\hline & Wed PM & 1.87 & 0.37 & 0.26 & 0.05 & 16.3 & 34.6 & 0.50 & 0.10 & 0.45 & 5.2 & 11.0 & 0.16 & 0.03 & 0.16 \\
\hline & Thur AM & 1.91 & 0.38 & 0.27 & 0.05 & 18.1 & 38.3 & 0.28 & 0.05 & 0.25 & 5.7 & 12.1 & 0.09 & 0.02 & 0.09 \\
\hline & Thur PM & 1.76 & 0.35 & 0.25 & 0.05 & 11.4 & 24.2 & 0.26 & 0.05 & 0.23 & 3.6 & 7.7 & 0.08 & 0.02 & 0.08 \\
\hline \multirow[t]{4}{*}{ CAJS01 } & Wed AM & 1.80 & 0.35 & 0.22 & 0.04 & 53.4 & 113.2 & 1.80 & 0.35 & 1.74 & 9.0 & 19.2 & 0.31 & 0.06 & 0.42 \\
\hline & Wed PM & 1.91 & 0.38 & 0.23 & 0.05 & 67.8 & 143.7 & 1.91 & 0.38 & 1.84 & 10.9 & 23.2 & 0.31 & 0.06 & 0.44 \\
\hline & Thur AM & 1.89 & 0.37 & 0.23 & 0.05 & 60.4 & 128.0 & 1.89 & 0.37 & 1.82 & 10.3 & 21.8 & 0.32 & 0.06 & 0.44 \\
\hline & Thur PM & 1.86 & 0.37 & 0.23 & 0.04 & 66.0 & 139.8 & 1.86 & 0.37 & 1.79 & 10.9 & 23.0 & 0.31 & 0.06 & 0.43 \\
\hline \multirow[t]{4}{*}{ CAJS02 } & Wed AM & 11.65 & 2.29 & 1.65 & 0.32 & & & 9.87 & 1.94 & 10.60 & & & 3.12 & 0.61 & 3.82 \\
\hline & Wed PM & 10.89 & 2.14 & 1.54 & 0.30 & 206.6 & 437.6 & 10.00 & 1.97 & 10.75 & 65.3 & 138.4 & 3.16 & 0.62 & 3.88 \\
\hline & Thur AM & 11.65 & 2.29 & 1.65 & 0.32 & 224.5 & 475.6 & 11.41 & 2.24 & 12.26 & 71.0 & 150.4 & 3.61 & 0.71 & 4.42 \\
\hline & Thur PM & 11.38 & 2.24 & 1.61 & 0.32 & 212.4 & 450.1 & 12.31 & 2.42 & 13.23 & 67.2 & 142.3 & 3.89 & 0.77 & 4.77 \\
\hline \multirow[t]{4}{*}{ CAJS03 } & Wed AM & 4.04 & 0.79 & 0.70 & 0.14 & 128.5 & 272.3 & 4.04 & 0.79 & 4.34 & 42.6 & 90.3 & 1.34 & 0.26 & 1.62 \\
\hline & Wed PM & 4.16 & 0.82 & 0.72 & 0.14 & 94.2 & 199.6 & 4.16 & 0.82 & 4.46 & 31.2 & 66.2 & 1.38 & 0.27 & 1.67 \\
\hline & Thur AM & 4.25 & 0.84 & 0.74 & 0.14 & 113.5 & 240.5 & 4.25 & 0.84 & 4.57 & 37.7 & 79.8 & 1.41 & 0.28 & 1.71 \\
\hline & Thur PM & 4.17 & 0.82 & 0.72 & 0.14 & 101.9 & 215.9 & 4.16 & 0.82 & 4.46 & 33.8 & 71.6 & 1.38 & 0.27 & 1.67 \\
\hline \multirow[t]{4}{*}{ CAJS21 } & Wed AM & 8.86 & 1.74 & 1.11 & 0.22 & 53.4 & 113.2 & 3.93 & 0.77 & 3.64 & 13.1 & 27.8 & 0.97 & 0.19 & 1.09 \\
\hline & Wed PM & 7.93 & 1.56 & 0.98 & 0.19 & 69.7 & 147.7 & 4.14 & 0.81 & 3.83 & 17.4 & 36.9 & 1.03 & 0.20 & 1.16 \\
\hline & Thur AM & 7.59 & 1.49 & 0.94 & 0.18 & 85.1 & 180.3 & 4.61 & 0.91 & 4.27 & 20.6 & 43.5 & 1.11 & 0.22 & 1.27 \\
\hline & Thur PM & 8.20 & 1.61 & 1.02 & 0.20 & 104.1 & 220.6 & 4.47 & 0.88 & 4.14 & 25.5 & 53.9 & 1.09 & 0.22 & 1.24 \\
\hline \multirow[t]{4}{*}{ CAJS22 } & Wed AM & 2.45 & 0.48 & 0.35 & 0.07 & 5.7 & 12.0 & 0.21 & 0.04 & 0.19 & 19.7 & 41.8 & 0.72 & 0.14 & 0.66 \\
\hline & Wed PM & 2.95 & 0.58 & 0.42 & 0.08 & 12.0 & 25.5 & 0.42 & 0.08 & 0.39 & 23.1 & 48.9 & 0.81 & 0.16 & 0.75 \\
\hline & Thur AM & 2.36 & 0.47 & 0.33 & 0.07 & 16.6 & 35.1 & 0.49 & 0.10 & 0.45 & 20.8 & 44.0 & 0.61 & 0.12 & 0.57 \\
\hline & Thur PM & 2.93 & 0.58 & 0.41 & 0.08 & 16.1 & 34.0 & 0.62 & 0.12 & 0.56 & 19.7 & 41.7 & 0.76 & 0.15 & 0.70 \\
\hline \multirow[t]{4}{*}{ CAJS23 } & Wed AM & 12.80 & 2.52 & 1.81 & 0.36 & 16.7 & 35.5 & 0.94 & 0.19 & 0.86 & 5.3 & 11.2 & 0.30 & 0.06 & 0.31 \\
\hline & Wed PM & 11.29 & 2.22 & 1.60 & 0.31 & 21.6 & 45.8 & 1.15 & 0.23 & 1.05 & 6.8 & 14.5 & 0.36 & 0.07 & 0.38 \\
\hline & Thur AM & 12.67 & 2.49 & 1.79 & 0.35 & 20.6 & 43.6 & 1.09 & 0.21 & 1.00 & 6.5 & 13.8 & 0.34 & 0.07 & 0.36 \\
\hline & Thur PM & 13.01 & 2.56 & 1.84 & 0.36 & 28.9 & 61.2 & 1.24 & 0.24 & 1.13 & 9.1 & 19.4 & 0.39 & 0.08 & 0.41 \\
\hline \multirow[t]{4}{*}{ CAJW18 } & Wed AM & 6.72 & 1.32 & 0.95 & 0.19 & 17.2 & 36.5 & 0.54 & 0.11 & 0.53 & 5.5 & 11.6 & 0.17 & 0.03 & 0.19 \\
\hline & Wed PM & 7.02 & 1.38 & 0.99 & 0.20 & 18.1 & 38.3 & 0.53 & 0.11 & 0.52 & 5.7 & 12.1 & 0.17 & 0.03 & 0.19 \\
\hline & Thur AM & 6.88 & 1.35 & 0.97 & 0.19 & 22.9 & 48.4 & 0.60 & 0.12 & 0.58 & 7.2 & 15.3 & 0.19 & 0.04 & 0.21 \\
\hline & Thur PM & 7.76 & 1.53 & 1.10 & 0.22 & 22.3 & 47.3 & 0.60 & 0.12 & 0.58 & 7.1 & 15.0 & 0.19 & 0.04 & 0.21 \\
\hline \multirow[t]{4}{*}{ CAJW19 } & Wed AM & 7.19 & 1.41 & 1.24 & 0.24 & 116.4 & 246.5 & 3.57 & 0.70 & 3.46 & 45.5 & 96.4 & 1.40 & 0.27 & 1.48 \\
\hline & Wed PM & 7.05 & 1.39 & 1.22 & 0.24 & 90.8 & 192.4 & 2.85 & 0.56 & 2.76 & 47.8 & 101.2 & 1.50 & 0.30 & 1.53 \\
\hline & Thur AM & 7.19 & 1.41 & 1.24 & 0.24 & 112.8 & 239.0 & 3.54 & 0.70 & 3.43 & 44.7 & 94.6 & 1.40 & 0.28 & 1.48 \\
\hline & Thur PM & 6.83 & 1.34 & 1.18 & 0.23 & 71.3 & 151.0 & 2.24 & 0.44 & 2.17 & 50.0 & 106.0 & 1.57 & 0.31 & 1.57 \\
\hline \multirow[t]{4}{*}{ CAJW20 } & Wed AM & 1.88 & 0.37 & 0.33 & 0.06 & 71.7 & 151.9 & 2.29 & 0.45 & 1.99 & 23.8 & 50.4 & 0.75 & 0.15 & 0.75 \\
\hline & Wed PM & 2.07 & 0.41 & 0.36 & 0.07 & 84.5 & 179.1 & 2.39 & 0.47 & 2.08 & 28.0 & 59.4 & 0.78 & 0.15 & 0.78 \\
\hline & Thur AM & 1.82 & 0.36 & 0.32 & 0.06 & 72.9 & 154.5 & 2.08 & 0.41 & 1.82 & 24.2 & 51.2 & 0.68 & 0.14 & 0.68 \\
\hline & Thur PM & 1.87 & 0.37 & 0.32 & 0.06 & 69.9 & 148.0 & 2.08 & 0.41 & 1.84 & 23.2 & 49.1 & 0.69 & 0.14 & 0.69 \\
\hline
\end{tabular}




\begin{tabular}{|c|c|c|c|c|c|c|c|c|c|c|c|c|c|c|c|}
\hline \multirow{3}{*}{\begin{tabular}{|c} 
Study Space \\
ID
\end{tabular}} & \multirow[b]{3}{*}{ Period } & \multicolumn{4}{|c|}{ SUPPLY AIRFLOW } & \multicolumn{10}{|c|}{ OUTDOOR AIRFLOW } \\
\hline & & \multicolumn{2}{|c|}{\begin{tabular}{|c} 
Volumetric supply \\
airflow
\end{tabular}} & \multicolumn{2}{|c|}{$\begin{array}{l}\text { Uncertainty in } \\
\text { supply airflow }\end{array}$} & \multicolumn{5}{|c|}{ Volumetric } & \multicolumn{5}{|c|}{ Uncertainty in volumetric $\mathrm{OA}$} \\
\hline & & $\mathrm{L} / \mathrm{s} \cdot \mathrm{m}^{2}$ & $\mathrm{cfm} / \mathrm{ft}$ & $\mathrm{L} / \mathrm{s} \cdot \mathrm{m}^{2}$ & $\mathrm{cfm} / \mathrm{ft}$ & L/s•person & $\mathrm{cfm} /$ person & $\mathrm{L} / \mathrm{s} \cdot \mathrm{m}^{2}$ & $\mathrm{cfm} / \mathrm{ft}$ & $h^{-1}$ & L/s•person & $\mathrm{cfm} /$ person & $\mathrm{L} / \mathrm{s} \cdot \mathrm{m}^{2}$ & $\mathrm{cfm} / \mathrm{ft}^{2}$ & $\mathrm{~h}^{-1}$ \\
\hline \multirow[t]{6}{*}{ CAJW24 } & Tues AM & 6.26 & 1.23 & 1.08 & 0.21 & 63.2 & 133.8 & 4.33 & 0.85 & 4.12 & 20.9 & 44.4 & 1.44 & 0.28 & 1.54 \\
\hline & Tues PM & 6.72 & 1.32 & 1.16 & 0.23 & 3.3 & 7.0 & 0.24 & 0.05 & 0.23 & 1.1 & 2.3 & 0.08 & 0.02 & 0.09 \\
\hline & Wed AM & 6.26 & 1.23 & 1.08 & 0.21 & 64.1 & 135.8 & 4.33 & 0.85 & 4.12 & 21.3 & 45.0 & 1.44 & 0.28 & 1.54 \\
\hline & Wed PM & 7.14 & 1.41 & 1.24 & 0.24 & 3.8 & 8.0 & 0.24 & 0.05 & 0.23 & 1.2 & 2.6 & 0.08 & 0.02 & 0.09 \\
\hline & Thur AM & 7.56 & 1.49 & 1.31 & 0.26 & 77.3 & 163.8 & 5.30 & 1.04 & 5.04 & 25.6 & 54.3 & 1.76 & 0.35 & 1.89 \\
\hline & Thur PM & 7.60 & 1.50 & 1.32 & 0.26 & 113.0 & 239.4 & 6.73 & 1.33 & 6.41 & 37.5 & 79.4 & 2.23 & 0.44 & 2.40 \\
\hline \multirow[t]{4}{*}{\begin{tabular}{|l} 
CAJW25 \\
\end{tabular}} & Wed AM & 4.96 & 0.98 & 0.86 & 0.17 & 47.6 & 100.9 & 2.67 & 0.53 & 2.56 & 15.8 & 33.5 & 0.89 & 0.17 & 0.96 \\
\hline & Wed PM & 5.23 & 1.03 & 0.91 & 0.18 & 85.0 & 180.0 & 5.00 & 0.98 & 4.79 & 28.2 & 59.7 & 1.66 & 0.33 & 1.79 \\
\hline & Thur AM & 4.62 & 0.91 & 0.80 & 0.16 & 61.5 & 130.3 & 3.28 & 0.65 & 3.14 & 20.4 & 43.2 & 1.09 & 0.21 & 1.18 \\
\hline & Thur PM & 5.14 & 1.01 & 0.89 & 0.18 & 78.5 & 166.4 & 5.26 & 1.04 & 5.04 & 26.0 & 55.2 & 1.74 & 0.34 & 1.88 \\
\hline \multirow[t]{4}{*}{\begin{tabular}{|l|} 
CAJW26 \\
\end{tabular}} & Wed AM & 5.26 & 1.04 & 0.91 & 0.18 & 133.7 & 283.3 & 5.98 & 1.18 & 5.73 & 44.4 & 94.0 & 1.98 & 0.39 & 2.14 \\
\hline & Wed PM & 5.92 & 1.17 & 1.03 & 0.20 & 115.1 & 243.8 & 6.58 & 1.30 & 6.30 & 38.2 & 80.9 & 2.18 & 0.43 & 2.36 \\
\hline & Thur AM & 5.52 & 1.09 & 0.96 & 0.19 & 88.5 & 187.5 & 5.89 & 1.16 & 5.64 & 29.3 & 62.2 & 1.95 & 0.38 & 2.11 \\
\hline & Thur PM & 5.80 & 1.14 & 1.00 & 0.20 & 87.7 & 185.7 & 5.47 & 1.08 & 5.24 & 29.1 & 61.6 & 1.81 & 0.36 & 1.96 \\
\hline \multirow[t]{4}{*}{\begin{tabular}{|l}
$\mathrm{COAS} 02$ \\
\end{tabular}} & Wed AM & 3.37 & 0.66 & 1.06 & 0.21 & 6.9 & 14.6 & 0.24 & 0.05 & 0.17 & 2.3 & 4.8 & 0.08 & 0.02 & 0.06 \\
\hline & Wed PM & 2.99 & 0.59 & 0.91 & 0.18 & 9.5 & 20.2 & 0.32 & 0.06 & 0.23 & 3.2 & 6.7 & 0.11 & 0.02 & 0.09 \\
\hline & Thur AM & 3.28 & 0.65 & 1.01 & 0.20 & 9.6 & 20.4 & 0.29 & 0.06 & 0.21 & 3.2 & 6.8 & 0.10 & 0.02 & 0.08 \\
\hline & Thur PM & 3.59 & 0.71 & 1.08 & 0.21 & 15.8 & 33.4 & 0.46 & 0.09 & 0.33 & 5.2 & 11.1 & 0.15 & 0.03 & 0.12 \\
\hline \multirow[t]{4}{*}{ COAS04 } & Wed AM & 5.83 & 1.15 & 1.01 & 0.20 & 4.4 & 9.4 & 0.13 & 0.03 & 0.10 & 60.0 & 127.1 & 1.81 & 0.36 & 1.30 \\
\hline & Wed PM & 5.94 & 1.17 & 1.03 & 0.20 & 12.7 & 26.8 & 0.39 & 0.08 & 0.28 & 57.7 & 122.3 & 1.77 & 0.35 & 1.28 \\
\hline & Thur AM & 5.71 & 1.12 & 0.99 & 0.19 & 1.0 & 2.1 & 0.03 & 0.01 & 0.02 & 67.4 & 142.8 & 1.80 & 0.35 & 1.30 \\
\hline & Thur PM & 5.85 & 1.15 & 1.01 & 0.20 & 0.0 & 0.0 & 0.00 & 0.00 & 0.00 & 60.1 & 127.3 & 1.9 & 0.37 & 1.35 \\
\hline \multirow[t]{4}{*}{ COAS06 } & Wed AM & 2.80 & 0.55 & 0.40 & 0.08 & 27.3 & 57.7 & 0.68 & 0.13 & 0.64 & 8.6 & 18.3 & 0.21 & 0.04 & 0.23 \\
\hline & Wed PM & 3.52 & 0.69 & 0.50 & 0.10 & 25.6 & 54.3 & 0.73 & 0.14 & 0.69 & 8.1 & 17.2 & 0.23 & 0.05 & 0.25 \\
\hline & Thur AM & 4.71 & 0.93 & 0.67 & 0.13 & 22.8 & 48.4 & 0.78 & 0.15 & 0.75 & 7.2 & 15.3 & 0.25 & 0.05 & 0.27 \\
\hline & Thur PM & 3.70 & 0.73 & 0.52 & 0.10 & 21.6 & 45.8 & 0.65 & 0.13 & 0.62 & 6.8 & 14.5 & 0.20 & 0.04 & 0.22 \\
\hline \multirow[t]{4}{*}{ FLDW07 } & Wed AM & 3.75 & 0.74 & 1.06 & 0.21 & 22.7 & 48.1 & 0.49 & 0.10 & 0.40 & 7.2 & 15.2 & 0.15 & 0.03 & 0.15 \\
\hline & Wed PM & 3.38 & 0.67 & 0.94 & 0.19 & 25.0 & 53.0 & 0.50 & 0.10 & 0.41 & 7.9 & 16.8 & 0.16 & 0.03 & 0.15 \\
\hline & Thur AM & 3.17 & 0.62 & 0.88 & 0.17 & 25.2 & 53.4 & 0.49 & 0.10 & 0.40 & 8.0 & 16.9 & 0.16 & 0.03 & 0.15 \\
\hline & Thur PM & 3.46 & 0.68 & 0.96 & 0.19 & 24.7 & 52.4 & 0.52 & 0.10 & 0.43 & 7.8 & 16.6 & 0.16 & 0.03 & 0.15 \\
\hline \multirow[t]{4}{*}{\begin{tabular}{|l|} 
FLDW08 \\
\end{tabular}} & Wed AM & 4.55 & 0.90 & 0.79 & 0.16 & 25.0 & 53.0 & 0.85 & 0.17 & 0.72 & 8.3 & 17.6 & 0.28 & 0.06 & 0.27 \\
\hline & Wed PM & 4.99 & 0.98 & 0.86 & 0.17 & 16.3 & 34.6 & 0.57 & 0.11 & 0.48 & 5.4 & 11.5 & 0.19 & 0.04 & 0.18 \\
\hline & Thur AM & 4.62 & 0.91 & 0.80 & 0.16 & 12.0 & 25.4 & 0.57 & 0.11 & 0.48 & 4.0 & 8.4 & 0.19 & 0.04 & 0.18 \\
\hline & Thur PM & 4.64 & 0.91 & 0.80 & 0.16 & 89.4 & 189.3 & 3.11 & 0.61 & 2.62 & 29.6 & 62.8 & 1.03 & 0.20 & 0.98 \\
\hline \multirow[t]{4}{*}{\begin{tabular}{|l|} 
FLDW10 \\
\end{tabular}} & Wed AM & 2.38 & 0.47 & 0.34 & 0.07 & 3.7 & 7.7 & 0.18 & 0.04 & 0.18 & 1.2 & 2.4 & 0.06 & 0.01 & 0.06 \\
\hline & Wed PM & 2.39 & 0.47 & 0.34 & 0.07 & 4.5 & 9.5 & 0.21 & 0.04 & 0.20 & 1.4 & 3.0 & 0.07 & 0.01 & 0.07 \\
\hline & Thur AM & 2.43 & 0.48 & 0.34 & 0.07 & 3.8 & 8.0 & 0.23 & 0.05 & 0.23 & 1.2 & 2.5 & 0.07 & 0.01 & 0.08 \\
\hline & Thur PM & 2.20 & 0.43 & 0.31 & 0.06 & 3.3 & 7.0 & 0.15 & 0.03 & 0.14 & 1.0 & 2.2 & 0.05 & 0.01 & 0.05 \\
\hline \multirow[t]{4}{*}{ FLGS01 } & Thur AM & 2.99 & 0.59 & 0.42 & 0.08 & 16.3 & 34.6 & 0.58 & 0.11 & 0.57 & 5.2 & 10.9 & 0.18 & 0.04 & 0.21 \\
\hline & Thur PM & 3.31 & 0.65 & 0.47 & 0.09 & 17.2 & 36.3 & 0.61 & 0.12 & 0.60 & 5.4 & 11.5 & 0.19 & 0.04 & 0.22 \\
\hline & Fri AM & 2.89 & 0.57 & 0.41 & 0.08 & 18.1 & 38.3 & 0.57 & 0.11 & 0.56 & 5.7 & 12.1 & 0.18 & 0.04 & 0.20 \\
\hline & Fri PM & 3.14 & 0.62 & 0.44 & 0.09 & 18.0 & 38.2 & 0.62 & 0.12 & 0.61 & 5.7 & 12.1 & 0.20 & 0.04 & 0.22 \\
\hline
\end{tabular}




\begin{tabular}{|c|c|c|c|c|c|c|c|c|c|c|c|c|c|c|c|}
\hline \multirow{3}{*}{$\begin{array}{l}\text { Study Space } \\
\text { ID }\end{array}$} & \multirow[b]{3}{*}{ Period } & \multicolumn{4}{|c|}{ SUPPLY AIRFLOW } & \multicolumn{10}{|c|}{ OUTDOOR AIRFLOW } \\
\hline & & \multicolumn{2}{|c|}{$\begin{array}{c}\text { Volumetric supply } \\
\text { airflow }\end{array}$} & \multicolumn{2}{|c|}{$\begin{array}{l}\text { Uncertainty in } \\
\text { supply airflow }\end{array}$} & \multicolumn{5}{|c|}{ Volumetric } & \multicolumn{5}{|c|}{ Uncertainty in volumetric OA } \\
\hline & & $\mathrm{L} / \mathrm{s} \cdot \mathrm{m}^{2}$ & $\mathrm{cfm} / \mathrm{ft}^{2}$ & $\mathrm{~L} / \mathrm{s} \bullet \mathrm{m}^{2}$ & $\mathrm{cfm} / \mathrm{ft}^{2}$ & $\mathrm{~L} / \mathrm{s} \bullet$ person & $\mathrm{cfm} /$ person & $\mathrm{L} / \mathrm{s} \cdot \mathrm{m}^{2}$ & $\mathrm{cfm} / \mathrm{ft}^{2}$ & $\mathrm{~h}^{-1}$ & $\mathrm{~L} / \mathrm{s} \bullet$ person & $\mathrm{cfm} /$ person & $\mathrm{L} / \mathrm{s} \cdot \mathrm{m}^{2}$ & $\mathrm{cfm} / \mathrm{ft}^{2}$ & $\mathrm{~h}^{-1}$ \\
\hline \multirow[t]{4}{*}{\begin{tabular}{|l|} 
FLGS04 \\
\end{tabular}} & Wed AM & 9.70 & 1.91 & 1.41 & 0.28 & 6.9 & 14.6 & 0.38 & 0.08 & 0.38 & 1.8 & 3.8 & 0.10 & 0.02 & 0.12 \\
\hline & Wed PM & 9.90 & 1.95 & 1.43 & 0.28 & 7.5 & 15.8 & 0.39 & 0.08 & 0.38 & 1.9 & 4.1 & 0.10 & 0.02 & 0.12 \\
\hline & Thur AM & 9.93 & 1.95 & 1.44 & 0.28 & 7.8 & 16.6 & 0.38 & 0.08 & 0.38 & 2.1 & 4.4 & 0.10 & 0.02 & 0.12 \\
\hline & Thur PM & 10.24 & 2.01 & 1.49 & 0.29 & 7.9 & 16.6 & 0.39 & 0.08 & 0.38 & 2.1 & 4.4 & 0.10 & 0.02 & 0.12 \\
\hline \multirow[t]{4}{*}{ FLGS11 } & Wed AM & 2.15 & 0.42 & 0.26 & 0.05 & 11.9 & 25.2 & 0.32 & 0.06 & 0.37 & 2.8 & 5.9 & 0.08 & 0.02 & 0.11 \\
\hline & Wed PM & 3.00 & 0.59 & 0.37 & 0.07 & 13.1 & 27.8 & 0.32 & 0.06 & 0.36 & 3.1 & 6.5 & 0.08 & 0.01 & 0.11 \\
\hline & Thur AM & 1.77 & 0.35 & 0.22 & 0.04 & 12.0 & 25.5 & 0.31 & 0.06 & 0.35 & 2.8 & 6.0 & 0.07 & 0.01 & 0.10 \\
\hline & Thur PM & 2.96 & 0.58 & 0.36 & 0.07 & 11.6 & 24.6 & 0.29 & 0.06 & 0.33 & 2.7 & 5.8 & 0.07 & 0.01 & 0.10 \\
\hline \multirow{4}{*}{ FLGS12 } & Wed AM & 9.03 & 1.78 & 2.48 & 0.49 & 37.3 & 79.1 & 1.48 & 0.29 & 1.58 & 11.8 & 25.0 & 0.47 & 0.09 & 0.57 \\
\hline & Wed PM & 8.69 & 1.71 & 2.37 & 0.47 & 34.5 & 73.1 & 1.49 & 0.29 & 1.60 & 10.9 & 23.1 & 0.47 & 0.09 & 0.58 \\
\hline & Thur AM & 8.09 & 1.59 & 2.18 & 0.43 & 35.4 & 75.0 & 1.50 & 0.29 & 1.60 & 11.2 & 23.7 & 0.47 & 0.09 & 0.58 \\
\hline & Thur PM & 7.90 & 1.55 & 2.15 & 0.42 & 25.6 & 54.3 & 1.38 & 0.27 & 1.48 & 8.1 & 17.2 & 0.44 & 0.09 & 0.53 \\
\hline \multirow[t]{4}{*}{ GADS01 } & Wed AM & 2.42 & 0.48 & 0.58 & 0.11 & 32.8 & 69.5 & 0.96 & 0.19 & 0.91 & 10.4 & 22.0 & 0.30 & 0.06 & 0.33 \\
\hline & Wed PM & 2.61 & 0.51 & 0.64 & 0.13 & 35.7 & 75.7 & 0.84 & 0.17 & 0.79 & 11.3 & 24.0 & 0.27 & 0.05 & 0.29 \\
\hline & Thur AM & 2.44 & 0.48 & 0.58 & 0.11 & 41.3 & 87.5 & 1.02 & 0.20 & 0.97 & 13.1 & 27.7 & 0.32 & 0.06 & 0.35 \\
\hline & Thur PM & 2.51 & 0.49 & 0.60 & 0.12 & 39.0 & 82.6 & 0.95 & 0.19 & 0.90 & 12.3 & 26.1 & 0.30 & 0.06 & 0.32 \\
\hline \multirow[t]{4}{*}{ GADS02 } & Wed AM & 3.06 & 0.60 & 0.37 & 0.07 & 36.0 & 76.3 & 0.63 & 0.12 & 0.60 & 8.6 & 18.2 & 0.15 & 0.03 & 0.18 \\
\hline & Wed PM & 3.52 & 0.69 & 0.43 & 0.08 & 29.9 & 63.4 & 0.62 & 0.12 & 0.59 & 7.0 & 14.9 & 0.15 & 0.03 & 0.17 \\
\hline & Thur AM & 3.05 & 0.60 & 0.37 & 0.07 & 35.4 & 74.9 & 0.65 & 0.13 & 0.61 & 8.3 & 17.6 & 0.15 & 0.03 & 0.18 \\
\hline & Thur PM & 3.71 & 0.73 & 0.45 & 0.09 & 33.9 & 71.8 & 0.64 & 0.13 & 0.61 & 8.0 & 16.9 & 0.15 & 0.03 & 0.18 \\
\hline \multirow[t]{4}{*}{ GADS03 } & Wed AM & 5.79 & 1.14 & 0.82 & 0.16 & 11.7 & 24.7 & 0.46 & 0.09 & 0.46 & 3.7 & 7.8 & 0.15 & 0.03 & 0.17 \\
\hline & Wed PM & 5.53 & 1.09 & 0.78 & 0.15 & 9.9 & 21.0 & 0.47 & 0.09 & 0.47 & 3.1 & 6.6 & 0.15 & 0.03 & 0.17 \\
\hline & Thur AM & 5.51 & 1.08 & 0.78 & 0.15 & 10.8 & 22.9 & 0.47 & 0.09 & 0.47 & 3.4 & 7.2 & 0.15 & 0.03 & 0.17 \\
\hline & Thur PM & 5.44 & 1.07 & 0.77 & 0.15 & 11.6 & 24.7 & 0.47 & 0.09 & 0.47 & 3.7 & 7.8 & 0.15 & 0.03 & 0.17 \\
\hline \multirow[t]{4}{*}{ ILBS01 } & Wed AM & 5.55 & 1.09 & 0.72 & 0.14 & & & & & & & & & & \\
\hline & Wed PM & 5.61 & 1.10 & 0.73 & 0.14 & & & & & & & & & & \\
\hline & Thur AM & 5.34 & 1.05 & 0.69 & 0.14 & & & & & & & & & & \\
\hline & Thur PM & 5.68 & 1.12 & 0.74 & 0.15 & & & & & & & & & & \\
\hline \multirow[t]{4}{*}{ ILBS02 } & Wed AM & 7.32 & 1.44 & 1.04 & 0.20 & 18.1 & 38.4 & 0.61 & 0.12 & 0.68 & 5.7 & 12.1 & 0.19 & 0.04 & 0.25 \\
\hline & Wed PM & 7.60 & 1.50 & 1.08 & 0.21 & 18.9 & 40.1 & 0.56 & 0.11 & 0.63 & 6.0 & 12.7 & 0.18 & 0.03 & 0.23 \\
\hline & Thur AM & 7.12 & 1.40 & 1.01 & 0.20 & 21.6 & 45.8 & 0.48 & 0.10 & 0.55 & 6.8 & 14.5 & 0.15 & 0.03 & 0.20 \\
\hline & Thur PM & 7.28 & 1.43 & 1.03 & 0.20 & 23.6 & 50.0 & 0.55 & 0.11 & 0.62 & 7.5 & 15.8 & 0.17 & 0.03 & 0.22 \\
\hline \multirow[t]{4}{*}{ ILBS03 } & Wed AM & 10.25 & 2.02 & 1.45 & 0.29 & 139.9 & 296.3 & 3.71 & 0.73 & 3.82 & 84.6 & 179.2 & 2.24 & 0.44 & 2.40 \\
\hline & Wed PM & 10.70 & 2.11 & 1.51 & 0.30 & 113.7 & 240.9 & 3.81 & 0.75 & 3.92 & 70.4 & 149.2 & 2.36 & 0.46 & 2.52 \\
\hline & Thur AM & 10.35 & 2.04 & 1.46 & 0.29 & 218.9 & 463.7 & 4.84 & 0.95 & 4.98 & 90.9 & 192.6 & 2.01 & 0.40 & 2.24 \\
\hline & Thur PM & 9.91 & 1.95 & 1.40 & 0.28 & 132.1 & 279.9 & 4.17 & 0.82 & 4.29 & 64.2 & 136.1 & 2.03 & 0.40 & 2.21 \\
\hline \multirow[t]{4}{*}{ LAGW04 } & Wed AM & 5.49 & 1.08 & 0.78 & 0.15 & 14.9 & 31.5 & 0.36 & 0.07 & 0.37 & 3.7 & 7.7 & 0.09 & 0.02 & 0.11 \\
\hline & Wed PM & 5.65 & 1.11 & 0.81 & 0.16 & 12.4 & 26.4 & 0.33 & 0.06 & 0.34 & 3.1 & 6.5 & 0.08 & 0.02 & 0.10 \\
\hline & Thur AM & 5.32 & 1.05 & 0.76 & 0.15 & 15.6 & 33.0 & 0.37 & 0.07 & 0.38 & 3.8 & 8.1 & 0.09 & 0.02 & 0.11 \\
\hline & Thur PM & 5.67 & 1.12 & 0.81 & 0.16 & 15.2 & 32.2 & 0.35 & 0.07 & 0.36 & 3.7 & 7.9 & 0.09 & 0.02 & 0.11 \\
\hline
\end{tabular}




\begin{tabular}{|c|c|c|c|c|c|c|c|c|c|c|c|c|c|c|c|}
\hline \multirow{3}{*}{$\begin{array}{c}\text { Study Space } \\
\text { ID }\end{array}$} & \multirow[b]{3}{*}{ Period } & \multicolumn{4}{|c|}{ SUPPLY AIRFLOW } & \multicolumn{10}{|c|}{ OUTDOOR AIRFLOW } \\
\hline & & \multicolumn{2}{|c|}{$\begin{array}{c}\text { Volumetric supply } \\
\text { airflow }\end{array}$} & \multicolumn{2}{|c|}{$\begin{array}{l}\text { Uncertainty in } \\
\text { supply airflow }\end{array}$} & \multicolumn{5}{|c|}{ Volumetric } & \multicolumn{5}{|c|}{ Uncertainty in volumetric OA } \\
\hline & & $\mathrm{L} / \mathrm{s} \cdot \mathrm{m}^{2}$ & $\mathrm{cfm} / \mathrm{ft}^{2}$ & $\mathrm{~L} / \mathrm{s} \bullet \mathrm{m}^{2}$ & $\mathrm{cfm} / \mathrm{ft}^{2}$ & $\mathrm{~L} / \mathrm{s} \bullet$ person & $\mathrm{cfm} /$ person & $\mathrm{L} / \mathrm{s} \bullet \mathrm{m}^{2}$ & $\mathrm{cfm} / \mathrm{ft}^{2}$ & $\mathrm{~h}^{-1}$ & $\mathrm{~L} / \mathrm{s} \bullet$ person & $\mathrm{cfm} /$ person & $\mathrm{L} / \mathrm{s} \cdot \mathrm{m}^{2}$ & $\mathrm{cfm} / \mathrm{ft}^{2}$ & $\mathrm{~h}^{-1}$ \\
\hline \multirow[t]{4}{*}{ LAGW05 } & Wed AM & 16.24 & 3.20 & 2.02 & 0.40 & 56.8 & 120.3 & 3.09 & 0.61 & 3.05 & 18.0 & 38.0 & 0.98 & 0.19 & 1.10 \\
\hline & Wed PM & 15.81 & 3.11 & 1.97 & 0.39 & 95.4 & 202.2 & 3.46 & 0.68 & 3.41 & 30.2 & 63.9 & 1.09 & 0.22 & 1.23 \\
\hline & Thur AM & 16.12 & 3.17 & 2.00 & 0.39 & 34.1 & 72.3 & 3.25 & 0.64 & 3.21 & 10.8 & 22.9 & 1.03 & 0.20 & 1.16 \\
\hline & Thur PM & 15.76 & 3.10 & 1.96 & 0.39 & 63.0 & 133.4 & 3.43 & 0.67 & 3.38 & 19.9 & 42.2 & 1.08 & 0.21 & 1.22 \\
\hline \multirow[t]{4}{*}{ LAGW06 } & Wed AM & 5.11 & 1.00 & 0.72 & 0.14 & 14.8 & 31.4 & 0.65 & 0.13 & 0.64 & 4.7 & 9.9 & 0.20 & 0.04 & 0.23 \\
\hline & Wed PM & 5.14 & 1.01 & 0.73 & 0.14 & 23.0 & 48.7 & 0.63 & 0.12 & 0.62 & 7.3 & 15.4 & 0.20 & 0.04 & 0.22 \\
\hline & Thur AM & 5.12 & 1.01 & 0.72 & 0.14 & 19.9 & 42.2 & 0.62 & 0.12 & 0.62 & 6.3 & 13.4 & 0.20 & 0.04 & 0.22 \\
\hline & Thur PM & 5.15 & 1.01 & 0.73 & 0.14 & 17.8 & 37.8 & 0.63 & 0.12 & 0.62 & 5.6 & 12.0 & 0.20 & 0.04 & 0.23 \\
\hline \multirow[t]{4}{*}{ MABW05 } & Wed AM & 0.88 & 0.17 & 0.13 & 0.03 & 2.7 & 5.7 & 0.09 & 0.02 & 0.08 & 6.4 & 13.5 & 0.21 & 0.04 & 0.19 \\
\hline & Wed PM & 1.34 & 0.26 & 0.21 & 0.04 & 10.9 & 23.0 & 0.32 & 0.06 & 0.30 & 9.6 & 20.4 & 0.29 & 0.06 & 0.27 \\
\hline & Thur AM & 1.29 & 0.25 & 0.20 & 0.04 & 6.9 & 14.6 & 0.23 & 0.04 & 0.21 & 9.0 & 19.0 & 0.29 & 0.06 & 0.28 \\
\hline & Thur PM & 1.34 & 0.26 & 0.21 & 0.04 & 9.3 & 19.8 & 0.29 & 0.06 & 0.27 & 9.3 & 19.6 & 0.29 & 0.06 & 0.27 \\
\hline \multirow[t]{4}{*}{ MABW06 } & Wed AM & 2.23 & 0.44 & 0.31 & 0.06 & 39.3 & 83.3 & 2.07 & 0.41 & 2.08 & 12.4 & 26.3 & 0.65 & 0.13 & 0.75 \\
\hline & Wed PM & 2.20 & 0.43 & 0.31 & 0.06 & 41.1 & 87.0 & 2.12 & 0.42 & 2.13 & 13.0 & 27.5 & 0.67 & 0.13 & 0.77 \\
\hline & Thur AM & 1.88 & 0.37 & 0.27 & 0.05 & 41.0 & 86.9 & 1.82 & 0.36 & 1.82 & 13.0 & 27.5 & 0.57 & 0.11 & 0.66 \\
\hline & Thur PM & 1.82 & 0.36 & 0.26 & 0.05 & 32.2 & 68.2 & 1.77 & 0.35 & 1.77 & 10.2 & 21.6 & 0.56 & 0.11 & 0.64 \\
\hline \multirow[t]{4}{*}{ MABW08 } & Wed AM & 4.48 & 0.88 & 0.76 & 0.15 & 54.1 & 114.6 & 3.30 & 0.65 & 3.30 & 24.7 & 52.3 & 1.50 & 0.30 & 1.61 \\
\hline & Wed PM & 4.56 & 0.90 & 0.77 & 0.15 & 44.9 & 95.1 & 3.47 & 0.68 & 3.48 & 19.9 & 42.1 & 1.54 & 0.30 & 1.66 \\
\hline & Thur AM & 4.31 & 0.85 & 0.73 & 0.14 & 38.3 & 81.1 & 2.87 & 0.56 & 2.88 & 9.8 & 20.7 & 0.73 & 0.14 & 0.89 \\
\hline & Thur PM & 4.40 & 0.87 & 0.74 & 0.15 & 36.4 & 77.1 & 3.07 & 0.60 & 3.08 & 8.6 & 18.2 & 0.73 & 0.14 & 0.90 \\
\hline \multirow[t]{4}{*}{ MDDS01 } & Wed AM & 5.06 & 1.00 & 0.88 & 0.17 & 14.6 & 30.9 & 0.57 & 0.11 & 0.44 & 36.7 & 77.7 & 1.44 & 0.28 & 1.10 \\
\hline & Wed PM & 5.41 & 1.06 & 0.94 & 0.18 & 13.7 & 29.0 & 0.34 & 0.07 & 0.26 & 64.5 & 136.7 & 1.61 & 0.32 & 1.23 \\
\hline & \begin{tabular}{|l|} 
Thur AM \\
\end{tabular} & 4.83 & 0.95 & 0.84 & 0.16 & 0.0 & 0.0 & 0.0 & 0.00 & 0.00 & 57.7 & 122.3 & 1.88 & 0.37 & 1.41 \\
\hline & Thur PM & 4.73 & 0.93 & 0.82 & 0.16 & 0.0 & 0.0 & 0.0 & 0.00 & 0.00 & 45.9 & 97.2 & 1.63 & 0.32 & 1.25 \\
\hline \multirow[t]{4}{*}{ MDDS03 } & Wed AM & 2.29 & 0.45 & 0.28 & 0.06 & 3.8 & 8.0 & 0.18 & 0.04 & 0.22 & 1.0 & 2.1 & 0.05 & 0.01 & 0.07 \\
\hline & Wed PM & 2.16 & 0.43 & 0.27 & 0.05 & 2.9 & 6.2 & 0.14 & 0.03 & 0.16 & 0.8 & 1.7 & 0.04 & 0.01 & 0.05 \\
\hline & Thur AM & 2.25 & 0.44 & 0.28 & 0.05 & 3.6 & 7.5 & 0.17 & 0.03 & 0.20 & 0.9 & 1.9 & 0.04 & 0.01 & 0.06 \\
\hline & \begin{tabular}{|l|} 
Thur PM \\
\end{tabular} & 2.21 & 0.43 & 0.27 & 0.05 & 4.0 & 8.5 & 0.16 & 0.03 & 0.19 & 1.0 & 2.2 & 0.04 & 0.01 & 0.06 \\
\hline \multirow[t]{4}{*}{ MDDS04 } & Wed AM & 4.02 & 0.79 & 0.49 & 0.10 & 17.6 & 37.4 & 0.74 & 0.15 & 0.60 & 18.3 & 38.7 & 0.77 & 0.15 & 0.63 \\
\hline & Wed PM & 3.81 & 0.75 & 0.47 & 0.09 & 15.7 & 33.3 & 0.63 & 0.12 & 0.52 & 18.5 & 39.2 & 0.74 & 0.15 & 0.61 \\
\hline & Thur AM & 3.88 & 0.76 & 0.48 & 0.09 & 16.4 & 34.8 & 0.60 & 0.12 & 0.49 & 20.7 & 43.9 & 0.76 & 0.15 & 0.63 \\
\hline & Thur PM & 3.74 & 0.74 & 0.46 & 0.09 & 13.9 & 29.5 & 0.61 & 0.12 & 0.50 & 16.8 & 35.6 & 0.73 & 0.14 & 0.60 \\
\hline \multirow[t]{4}{*}{ MIBW01 } & Wed AM & 3.08 & 0.61 & 0.40 & 0.08 & 32.0 & 67.9 & 1.15 & 0.23 & 1.12 & 13.6 & 28.8 & 0.49 & 0.10 & 0.51 \\
\hline & Wed PM & 3.43 & 0.67 & 0.45 & 0.09 & 45.4 & 96.1 & 1.80 & 0.35 & 1.74 & 11.8 & 25.1 & 0.47 & 0.09 & 0.55 \\
\hline & Thur AM & 3.09 & 0.61 & 0.40 & 0.08 & & & & & & & & & & \\
\hline & Thur PM & 3.25 & 0.64 & 0.42 & 0.08 & & & & & & & & & & \\
\hline \multirow[t]{4}{*}{ MIBW03 } & Wed AM & 5.37 & 1.06 & 0.93 & 0.18 & 36.0 & 76.3 & 1.53 & 0.30 & 1.53 & 30.4 & 64.4 & 1.29 & 0.25 & 1.32 \\
\hline & Wed PM & 5.35 & 1.05 & 0.93 & 0.18 & 21.2 & 44.9 & 1.16 & 0.23 & 1.16 & 25.0 & 52.9 & 1.37 & 0.27 & 1.39 \\
\hline & Thur AM & 5.47 & 1.08 & 0.95 & 0.19 & 27.4 & 58.1 & 1.34 & 0.26 & 1.34 & 28.1 & 59.5 & 1.37 & 0.27 & 1.39 \\
\hline & Thur PM & 4.67 & 0.92 & 0.81 & 0.16 & 24.8 & 52.6 & 1.57 & 0.31 & 1.57 & 16.8 & 35.5 & 1.06 & 0.21 & 1.10 \\
\hline
\end{tabular}




\begin{tabular}{|c|c|c|c|c|c|c|c|c|c|c|c|c|c|c|c|}
\hline \multirow{3}{*}{$\begin{array}{l}\text { Study Space } \\
\text { ID }\end{array}$} & \multirow[b]{3}{*}{ Period } & \multicolumn{4}{|c|}{ SUPPLY AIRFLOW } & \multicolumn{10}{|c|}{ OUTDOOR AIRFLOW } \\
\hline & & \multicolumn{2}{|c|}{$\begin{array}{c}\text { Volumetric supply } \\
\text { airflow }\end{array}$} & \multicolumn{2}{|c|}{$\begin{array}{l}\text { Uncertainty in } \\
\text { supply airflow }\end{array}$} & \multicolumn{5}{|c|}{ Volumetric } & \multicolumn{5}{|c|}{ Uncertainty in volumetric $\mathrm{OA}$} \\
\hline & & $\mathrm{L} / \mathrm{s} \cdot \mathrm{m}^{2}$ & $\mathrm{cfm} / \mathrm{ft}^{2}$ & $\mathrm{~L} / \mathrm{s} \cdot \mathrm{m}^{2}$ & $\mathrm{cfm} / \mathrm{ft}^{2}$ & L/s•person & $\mathrm{cfm} /$ person & $\mathrm{L} / \mathrm{s} \cdot \mathrm{m}^{2}$ & $\mathrm{cfm} / \mathrm{ft}^{2}$ & $\mathrm{~h}^{-1}$ & L/s•person & cfm/person & $\mathrm{L} / \mathrm{s} \cdot \mathrm{m}^{2}$ & $\mathrm{cfm} / \mathrm{ft}^{2}$ & $\mathrm{~h}^{-1}$ \\
\hline \multirow[t]{4}{*}{ MIBW04 } & Wed AM & 2.71 & 0.53 & 0.39 & 0.08 & 21.8 & 40.1 & 0.97 & 0.19 & 0.97 & 10.0 & 21.3 & 0.45 & 0.09 & 0.48 \\
\hline & Wed PM & 2.64 & 0.52 & 0.38 & 0.08 & 22.6 & 47.9 & 0.94 & 0.19 & 0.94 & 10.6 & 22.4 & 0.44 & 0.09 & 0.47 \\
\hline & Thur AM & 2.70 & 0.53 & 0.39 & 0.08 & 17.5 & 37.1 & 0.69 & 0.14 & 0.69 & 12.2 & 25.9 & 0.48 & 0.10 & 0.50 \\
\hline & Thur PM & 2.96 & 0.58 & 0.43 & 0.08 & 37.8 & 80.2 & 1.12 & 0.22 & 1.12 & 16.1 & 34.1 & 0.47 & 0.09 & 0.51 \\
\hline \multirow[t]{4}{*}{ MNBW01 } & Wed AM & 2.81 & 0.55 & 0.40 & 0.08 & 38.1 & 80.7 & 0.73 & 0.14 & 0.72 & 12.0 & 25.5 & 0.23 & 0.05 & 0.26 \\
\hline & Wed PM & 3.18 & 0.63 & 0.45 & 0.09 & 39.8 & 84.2 & 0.74 & 0.14 & 0.72 & 12.6 & 26.6 & 0.23 & 0.05 & 0.26 \\
\hline & Thur AM & 2.83 & 0.56 & 0.40 & 0.08 & 39.7 & 84.1 & 0.71 & 0.14 & 0.70 & 12.6 & 26.6 & 0.22 & 0.04 & 0.25 \\
\hline & Thur PM & 3.11 & 0.61 & 0.44 & 0.09 & 50.7 & 107.3 & 0.77 & 0.15 & 0.76 & 16.0 & 33.9 & 0.24 & 0.05 & 0.27 \\
\hline \multirow[t]{4}{*}{ MNBW02 } & Wed AM & 3.58 & 0.70 & 0.51 & 0.10 & 49.6 & 105.1 & 1.02 & 0.20 & 1.10 & 12.2 & 25.8 & 0.25 & 0.05 & 0.33 \\
\hline & Wed PM & 4.20 & 0.83 & 0.59 & 0.12 & 58.3 & 123.5 & 1.52 & 0.30 & 1.63 & 14.6 & 30.9 & 0.38 & 0.07 & 0.50 \\
\hline & Thur AM & 2.91 & 0.57 & 0.41 & 0.08 & 54.7 & 115.8 & 1.50 & 0.30 & 1.61 & 13.6 & 28.7 & 0.37 & 0.07 & 0.49 \\
\hline & Thur PM & 3.42 & 0.67 & 0.48 & 0.10 & 62.0 & 131.4 & 1.49 & 0.29 & 1.60 & 15.2 & 32.2 & 0.37 & 0.07 & 0.48 \\
\hline \multirow[t]{4}{*}{ MNBW04 } & Wed AM & 2.71 & 0.53 & 0.47 & 0.09 & 108.6 & 230.1 & 1.95 & 0.38 & 2.14 & 36.0 & 76.3 & 0.65 & 0.13 & 0.80 \\
\hline & Wed PM & 2.59 & 0.51 & 0.45 & 0.09 & 229.1 & 485.3 & 2.12 & 0.42 & 2.33 & 76.0 & 161.0 & 0.70 & 0.14 & 0.87 \\
\hline & Thur AM & 2.97 & 0.59 & 0.52 & 0.10 & 98.1 & 207.7 & 2.10 & 0.41 & 2.31 & 32.5 & 68.9 & 0.70 & 0.14 & 0.86 \\
\hline & Thur PM & 2.62 & 0.52 & 0.45 & 0.09 & 101.8 & 215.8 & 2.24 & 0.44 & 2.46 & 33.8 & 71.6 & 0.74 & 0.15 & 0.92 \\
\hline \multirow[t]{4}{*}{\begin{tabular}{|l|} 
MOCS01 \\
\end{tabular}} & Wed AM & 2.61 & 0.51 & 0.45 & 0.09 & & & & & & & & & & \\
\hline & Wed PM & 3.10 & 0.61 & 0.54 & 0.11 & & & & & & & & & & \\
\hline & Thur AM & 2.81 & 0.55 & 0.49 & 0.10 & & & & & & & & & & \\
\hline & Thur PM & 3.07 & 0.60 & 0.53 & 0.10 & & & & & & & & & & \\
\hline \multirow[t]{4}{*}{\begin{tabular}{|l|} 
MOCS05 \\
\end{tabular}} & Wed AM & 3.10 & 0.61 & 0.54 & 0.11 & 31.8 & 67.5 & 1.02 & 0.20 & 0.91 & 10.6 & 22.4 & 0.34 & 0.07 & 0.34 \\
\hline & Wed PM & 3.43 & 0.68 & 0.59 & 0.12 & 39.8 & 84.4 & 1.21 & 0.24 & 1.08 & 13.2 & 28.0 & 0.40 & 0.08 & 0.40 \\
\hline & Thur AM & 2.79 & 0.55 & 0.48 & 0.09 & 21.2 & 44.9 & 0.61 & 0.12 & 0.55 & 7.0 & 14.9 & 0.20 & 0.04 & 0.20 \\
\hline & Thur PM & 2.69 & 0.53 & 0.47 & 0.09 & 2.1 & 4.5 & 0.07 & 0.01 & 0.06 & 0.7 & 1.5 & 0.02 & 0.00 & 0.02 \\
\hline \multirow[t]{4}{*}{\begin{tabular}{|l} 
NCDW02 \\
\end{tabular}} & Wed AM & 2.83 & 0.56 & 0.41 & 0.08 & 98.6 & 208.8 & 2.54 & 0.50 & 3.28 & 24.5 & 52.0 & 0.61 & 0.12 & 0.99 \\
\hline & Wed PM & 3.08 & 0.61 & 0.44 & 0.09 & 88.5 & 187.5 & 2.64 & 0.52 & 3.47 & 22.0 & 46.7 & 0.66 & 0.13 & 1.05 \\
\hline & Thur AM & 2.92 & 0.58 & 0.42 & 0.08 & 37.8 & 80.1 & 1.42 & 0.28 & 1.83 & 9.4 & 19.9 & 0.36 & 0.07 & 0.55 \\
\hline & Thur PM & 2.97 & 0.58 & 0.43 & 0.08 & 61.3 & 129.8 & 2.34 & 0.46 & 3.04 & 15.2 & 32.3 & 0.56 & 0.11 & 0.92 \\
\hline \multirow[t]{4}{*}{ NCDW03 } & Wed AM & & & & & & & & & & & & & & \\
\hline & Wed PM & & & & & & & & & & & & & & \\
\hline & Thur AM & & & & & & & & & & & & & & \\
\hline & Thur PM & & & & & & & & & & & & & & \\
\hline \multirow[t]{4}{*}{ NCDW06 } & Wed AM & 5.74 & 1.13 & 0.99 & 0.20 & 39.7 & 84.2 & 2.20 & 0.43 & 2.00 & 13.2 & 27.9 & 0.73 & 0.14 & 0.75 \\
\hline & Wed PM & 6.45 & 1.27 & 1.12 & 0.22 & 56.0 & 118.6 & 3.66 & 0.72 & 3.32 & 18.6 & 39.3 & 1.21 & 0.24 & 1.24 \\
\hline & Thur AM & 4.85 & 0.95 & 0.84 & 0.17 & 47.4 & 100.5 & 3.47 & 0.68 & 3.16 & 15.7 & 33.3 & 1.15 & 0.23 & 1.18 \\
\hline & Thur PM & 5.74 & 1.13 & 0.99 & 0.20 & 33.4 & 70.8 & 2.12 & 0.42 & 1.93 & 11.1 & 23.5 & 0.70 & 0.14 & 0.72 \\
\hline \multirow{4}{*}{ NECW01 } & Wed AM & 3.07 & 0.61 & 0.53 & 0.10 & 20.1 & 42.7 & 1.02 & 0.20 & 0.77 & 6.7 & 14.1 & 0.34 & 0.07 & 0.29 \\
\hline & Wed PM & 2.97 & 0.59 & 0.51 & 0.10 & 24.1 & 51.0 & 1.18 & 0.23 & 0.89 & 8.0 & 16.9 & 0.39 & 0.08 & 0.33 \\
\hline & Thur AM & 3.20 & 0.63 & 0.55 & 0.11 & 21.5 & 45.5 & 1.14 & 0.22 & 0.86 & 7.1 & 15.1 & 0.38 & 0.07 & 0.32 \\
\hline & Thur PM & 3.16 & 0.62 & 0.55 & 0.11 & & & 1.85 & 0.36 & 1.40 & & & 0.61 & 0.12 & 0.52 \\
\hline
\end{tabular}




\begin{tabular}{|c|c|c|c|c|c|c|c|c|c|c|c|c|c|c|c|}
\hline \multirow{3}{*}{$\begin{array}{l}\text { Study Space } \\
\text { ID }\end{array}$} & \multirow[b]{3}{*}{ Period } & \multicolumn{4}{|c|}{ SUPPLY AIRFLOW } & \multicolumn{10}{|c|}{ OUTDOOR AIRFLOW } \\
\hline & & \multicolumn{2}{|c|}{$\begin{array}{c}\text { Volumetric supply } \\
\text { airflow }\end{array}$} & \multicolumn{2}{|c|}{$\begin{array}{l}\text { Uncertainty in } \\
\text { supply airflow }\end{array}$} & \multicolumn{5}{|c|}{ Volumetric } & \multicolumn{5}{|c|}{ Uncertainty in volumetric $\mathrm{OA}$} \\
\hline & & $\mathrm{L} / \mathrm{s} \cdot \mathrm{m}^{2}$ & $\mathrm{cfm} / \mathrm{ft}^{2}$ & $\mathrm{~L} / \mathrm{s} \bullet \mathrm{m}^{2}$ & $\mathrm{cfm} / \mathrm{ft}^{2}$ & $\mathrm{~L} / \mathrm{s} \bullet$ person & $\mathrm{cfm} /$ person & $\mathrm{L} / \mathrm{s} \cdot \mathrm{m}^{2}$ & $\mathrm{cfm} / \mathrm{ft}^{2}$ & $\mathrm{~h}^{-1}$ & $\mathrm{~L} / \mathrm{s} \bullet$ person & $\mathrm{cfm} /$ person & $\mathrm{L} / \mathrm{s} \cdot \mathrm{m}^{2}$ & $\mathrm{cfm} / \mathrm{ft}^{2}$ & $\mathrm{~h}^{-1}$ \\
\hline \multirow[t]{4}{*}{ NECW02 } & Wed AM & 8.20 & 1.61 & 1.42 & 0.28 & 226.7 & 480.3 & 6.47 & 1.27 & 4.89 & 75.2 & 159.3 & 2.15 & 0.42 & 1.83 \\
\hline & Wed PM & 6.34 & 1.25 & 1.10 & 0.22 & 109.1 & 231.2 & 3.59 & 0.71 & 2.71 & 36.2 & 76.7 & 1.19 & 0.23 & 1.02 \\
\hline & Thur AM & 8.26 & 1.63 & 1.43 & 0.28 & 175.9 & 372.6 & 6.24 & 1.23 & 4.72 & 58.3 & 123.6 & 2.07 & 0.41 & 1.76 \\
\hline & Thur PM & 8.06 & 1.59 & 1.40 & 0.27 & 310.1 & 657.0 & 5.90 & 1.16 & 4.46 & 102.8 & 217.9 & 1.96 & 0.39 & 1.67 \\
\hline \multirow[t]{4}{*}{ NECW03 } & Wed AM & 6.28 & 1.24 & 1.09 & 0.21 & 65.8 & 139.4 & 4.31 & 0.85 & 4.32 & 21.8 & 46.2 & 1.43 & 0.28 & 1.62 \\
\hline & Wed PM & 7.11 & 1.40 & 1.23 & 0.24 & 78.1 & 165.4 & 4.76 & 0.94 & 4.77 & 25.9 & 54.9 & 1.58 & 0.31 & 1.79 \\
\hline & Thur AM & 7.34 & 1.44 & 1.27 & 0.25 & 51.7 & 109.4 & 3.42 & 0.67 & 3.43 & 17.1 & 36.3 & 1.14 & 0.22 & 1.28 \\
\hline & Thur PM & 6.47 & 1.27 & 1.12 & 0.22 & 87.0 & 184.4 & 5.70 & 1.12 & 5.72 & 28.9 & 61.2 & 1.89 & 0.37 & 2.14 \\
\hline \multirow[t]{4}{*}{ NMES01 } & Wed AM & 4.88 & 0.96 & 0.98 & 0.19 & 72.5 & 153.7 & 1.51 & 0.30 & 1.52 & 17.5 & 37.1 & 0.37 & 0.07 & 0.45 \\
\hline & Wed PM & 4.95 & 0.97 & 1.02 & 0.20 & 69.9 & 148.2 & 1.68 & 0.33 & 1.69 & 17.2 & 36.5 & 0.41 & 0.08 & 0.51 \\
\hline & Thur AM & 4.35 & 0.86 & 0.90 & 0.18 & 68.2 & 144.4 & 1.27 & 0.25 & 1.28 & 17.1 & 36.3 & 0.32 & 0.06 & 0.39 \\
\hline & Thur PM & 4.78 & 0.94 & 0.98 & 0.19 & 57.7 & 122.2 & 1.54 & 0.30 & 1.55 & 14.2 & 30.1 & 0.38 & 0.07 & 0.47 \\
\hline \multirow[t]{4}{*}{ NMES02 } & Wed AM & 5.30 & 1.04 & 0.75 & 0.15 & 183.2 & 388.2 & 7.34 & 1.44 & 6.85 & 57.9 & 122.8 & 2.32 & 0.46 & 2.47 \\
\hline & Wed PM & 5.88 & 1.16 & 0.83 & 0.16 & 203.8 & 431.8 & 7.30 & 1.44 & 6.81 & 64.5 & 136.6 & 2.31 & 0.45 & 2.45 \\
\hline & Thur AM & 6.31 & 1.24 & 0.89 & 0.18 & 186.5 & 395.2 & 6.84 & 1.35 & 6.38 & 59.0 & 125.0 & 2.16 & 0.43 & 2.30 \\
\hline & Thur PM & 5.09 & 1.00 & 0.72 & 0.14 & 201.7 & 427.2 & 7.74 & 1.52 & 7.21 & 63.8 & 135.1 & 2.45 & 0.48 & 2.60 \\
\hline \multirow[t]{4}{*}{ NMES03 } & Wed AM & 4.69 & 0.92 & 0.58 & 0.11 & 7.2 & 15.3 & 0.44 & 0.09 & 0.41 & 15.9 & 33.7 & 0.97 & 0.19 & 0.91 \\
\hline & Wed PM & 5.55 & 1.09 & 0.69 & 0.14 & 20.4 & 43.1 & 0.79 & 0.16 & 0.74 & 29.0 & 61.4 & 1.13 & 0.22 & 1.06 \\
\hline & Thur AM & 4.79 & 0.94 & 0.59 & 0.12 & 17.0 & 35.9 & 0.77 & 0.15 & 0.71 & 20.9 & 44.4 & 0.95 & 0.19 & 0.89 \\
\hline & Thur PM & 5.04 & 0.99 & 0.63 & 0.12 & 12.3 & 26.1 & 0.51 & 0.10 & 0.48 & 25.4 & 53.8 & 1.06 & 0.21 & 0.99 \\
\hline \multirow[t]{4}{*}{ NVAW01 } & Wed AM & 6.31 & 1.24 & 1.09 & 0.22 & 151.8 & 321.5 & 6.31 & 1.24 & 6.62 & 50.3 & 106.6 & 2.09 & 0.41 & 2.48 \\
\hline & Wed PM & 6.57 & 1.29 & 1.14 & 0.22 & 104.2 & 220.8 & 4.42 & 0.87 & 4.64 & 34.6 & 73.2 & 1.47 & 0.29 & 1.74 \\
\hline & Thur AM & 6.75 & 1.33 & 1.17 & 0.23 & 86.6 & 183.5 & 3.68 & 0.72 & 3.86 & 28.7 & 60.9 & 1.22 & 0.24 & 1.44 \\
\hline & Thur PM & 6.84 & 1.35 & 1.18 & 0.23 & 50.8 & 107.6 & 1.90 & 0.37 & 1.99 & 16.8 & 35.7 & 0.63 & 0.12 & 0.74 \\
\hline \multirow[t]{4}{*}{ NVAW02 } & Wed AM & 4.15 & 0.82 & 0.72 & 0.14 & 82.9 & 175.6 & 3.95 & 0.78 & 3.73 & 27.5 & 58.2 & 1.31 & 0.26 & 1.40 \\
\hline & Wed PM & 4.63 & 0.91 & 0.80 & 0.16 & 132.3 & 280.3 & 4.44 & 0.87 & 4.19 & 43.9 & 93.0 & 1.47 & 0.29 & 1.57 \\
\hline & Thur AM & 4.04 & 0.79 & 0.70 & 0.14 & 133.3 & 282.3 & 3.88 & 0.76 & 3.67 & 44.2 & 93.6 & 1.29 & 0.25 & 1.37 \\
\hline & Thur PM & 4.61 & 0.91 & 0.80 & 0.16 & 121.8 & 258.0 & 4.30 & 0.85 & 4.07 & 40.4 & 85.6 & 1.43 & 0.28 & 1.52 \\
\hline \multirow[t]{4}{*}{ NVAW03 } & Wed AM & 8.78 & 1.73 & 1.08 & 0.21 & 174.0 & 368.6 & 7.38 & 1.45 & 6.97 & 45.1 & 95.5 & 1.91 & 0.38 & 2.17 \\
\hline & Wed PM & 8.54 & 1.68 & 1.05 & 0.21 & 148.0 & 313.6 & 7.44 & 1.47 & 7.03 & 38.4 & 81.4 & 1.93 & 0.38 & 2.19 \\
\hline & Thur AM & 8.51 & 1.67 & 1.05 & 0.21 & 106.6 & 225.9 & 7.36 & 1.45 & 6.95 & 27.7 & 58.7 & 1.91 & 0.38 & 2.17 \\
\hline & Thur PM & 8.74 & 1.72 & 1.08 & 0.21 & 127.8 & 270.8 & 7.44 & 1.46 & 7.03 & 33.1 & 70.1 & 1.93 & 0.38 & 2.19 \\
\hline \multirow[t]{4}{*}{ NYBS01 } & Wed AM & 9.42 & 1.85 & 1.37 & 0.27 & 35.3 & 74.9 & 1.39 & 0.27 & 1.43 & 43.8 & 92.8 & 1.72 & 0.34 & 1.78 \\
\hline & Wed PM & 9.88 & 1.94 & 1.43 & 0.28 & 54.1 & 114.6 & 1.27 & 0.25 & 1.31 & 78.1 & 165.5 & 1.84 & 0.36 & 1.90 \\
\hline & Thur AM & 9.71 & 1.91 & 1.40 & 0.28 & 40.8 & 86.5 & 1.17 & 0.23 & 1.21 & 62.6 & 132.6 & 1.80 & 0.35 & 1.86 \\
\hline & Thur PM & 9.81 & 1.93 & 1.42 & 0.28 & 35.3 & 74.7 & 1.34 & 0.26 & 1.38 & 47.7 & 101.0 & 1.81 & 0.36 & 1.87 \\
\hline \multirow[t]{4}{*}{ NYBS02 } & Wed AM & 6.72 & 1.32 & 0.83 & 0.16 & 16.4 & 34.7 & 0.63 & 0.12 & 0.58 & 3.9 & 8.2 & 0.15 & 0.03 & 0.17 \\
\hline & Wed PM & 6.34 & 1.25 & 0.78 & 0.15 & 14.6 & 30.9 & 0.71 & 0.14 & 0.65 & 3.5 & 7.4 & 0.17 & 0.03 & 0.19 \\
\hline & Thur AM & 6.38 & 1.26 & 0.78 & 0.15 & 13.6 & 28.9 & 0.61 & 0.12 & 0.55 & 3.3 & 6.9 & 0.15 & 0.03 & 0.16 \\
\hline & Thur PM & 4.39 & 0.86 & 0.54 & 0.11 & 17.5 & 37.0 & 0.66 & 0.13 & 0.60 & 4.1 & 8.7 & 0.16 & 0.03 & 0.18 \\
\hline
\end{tabular}




\begin{tabular}{|c|c|c|c|c|c|c|c|c|c|c|c|c|c|c|c|}
\hline \multirow{3}{*}{$\begin{array}{l}\text { Study Space } \\
\text { ID }\end{array}$} & \multirow[b]{3}{*}{ Period } & \multicolumn{4}{|c|}{ SUPPLY AIRFLOW } & \multicolumn{10}{|c|}{ OUTDOOR AIRFLOW } \\
\hline & & \multicolumn{2}{|c|}{$\begin{array}{c}\text { Volumetric supply } \\
\text { airflow }\end{array}$} & \multicolumn{2}{|c|}{$\begin{array}{l}\text { Uncertainty in } \\
\text { supply airflow }\end{array}$} & \multicolumn{5}{|c|}{ Volumetric } & \multicolumn{5}{|c|}{ Uncertainty in volumetric $\mathrm{OA}$} \\
\hline & & $\mathrm{L} / \mathrm{s} \cdot \mathrm{m}^{2}$ & $\mathrm{cfm} / \mathrm{ft}^{2}$ & $\mathrm{~L} / \mathrm{s} \bullet \mathrm{m}^{2}$ & $\mathrm{cfm} / \mathrm{ft}^{2}$ & $\mathrm{~L} / \mathrm{s} \bullet$ person & $\mathrm{cfm} /$ person & $\mathrm{L} / \mathrm{s} \cdot \mathrm{m}^{2}$ & $\mathrm{cfm} / \mathrm{ft}^{2}$ & $\mathrm{~h}^{-1}$ & $\mathrm{~L} / \mathrm{s} \bullet$ person & $\mathrm{cfm} /$ person & $\mathrm{L} / \mathrm{s} \cdot \mathrm{m}^{2}$ & $\mathrm{cfm} / \mathrm{ft}^{2}$ & $\mathrm{~h}^{-1}$ \\
\hline \multirow[t]{4}{*}{ NYBS04 } & Wed AM & 5.40 & 1.06 & 0.76 & 0.15 & 3.3 & 7.1 & 0.14 & 0.03 & 0.14 & 0.9 & 1.9 & 0.04 & 0.01 & 0.05 \\
\hline & Wed PM & 5.42 & 1.07 & 0.77 & 0.15 & 3.9 & 8.3 & 0.13 & 0.03 & 0.13 & 1.0 & 2.2 & 0.04 & 0.01 & 0.04 \\
\hline & Thur AM & 5.70 & 1.12 & 0.81 & 0.16 & 99.0 & 209.8 & 4.78 & 0.94 & 4.84 & 24.4 & 51.6 & 1.18 & 0.23 & 1.46 \\
\hline & Thur PM & 5.69 & 1.12 & 0.80 & 0.16 & 3.5 & 7.5 & 0.14 & 0.03 & 0.14 & 1.0 & 2.0 & 0.04 & 0.01 & 0.04 \\
\hline \multirow[t]{4}{*}{ NYBS05 } & Wed AM & 2.50 & 0.49 & 0.43 & 0.09 & 12.8 & 27.1 & 0.64 & 0.13 & 0.54 & 4.2 & 9.0 & 0.21 & 0.04 & 0.20 \\
\hline & Wed PM & 2.69 & 0.53 & 0.47 & 0.09 & 13.8 & 29.2 & 0.64 & 0.13 & 0.55 & 4.6 & 9.7 & 0.21 & 0.04 & 0.20 \\
\hline & Thur AM & 2.60 & 0.51 & 0.45 & 0.09 & 14.5 & 30.8 & 0.64 & 0.13 & 0.55 & 4.8 & 10.2 & 0.21 & 0.04 & 0.20 \\
\hline & Thur PM & 2.62 & 0.52 & 0.45 & 0.09 & 12.3 & 26.2 & 0.59 & 0.12 & 0.51 & 4.1 & 8.7 & 0.20 & 0.04 & 0.19 \\
\hline \multirow[t]{4}{*}{ NYBS07 } & Wed AM & 4.87 & 0.96 & 1.30 & 0.26 & 18.3 & 38.8 & 0.97 & 0.19 & 0.90 & 5.8 & 12.3 & 0.31 & 0.06 & 0.32 \\
\hline & Wed PM & 5.10 & 1.00 & 1.36 & 0.27 & 27.1 & 57.5 & 1.02 & 0.20 & 0.94 & 8.6 & 18.2 & 0.32 & 0.06 & 0.34 \\
\hline & Thur AM & 5.03 & 0.99 & 1.34 & 0.26 & 21.4 & 45.4 & 1.03 & 0.20 & 0.96 & 6.8 & 14.4 & 0.33 & 0.06 & 0.34 \\
\hline & Thur PM & 4.81 & 0.95 & 1.28 & 0.25 & 23.8 & 50.5 & 0.96 & 0.19 & 0.89 & 7.5 & 16.0 & 0.30 & 0.06 & 0.32 \\
\hline \multirow[t]{4}{*}{ ORIS03 } & Wed AM & 3.89 & 0.77 & 0.71 & 0.14 & 64.9 & 137.6 & 1.75 & 0.34 & 1.62 & 21.5 & 45.6 & 0.58 & 0.11 & 0.61 \\
\hline & Wed PM & 4.52 & 0.89 & 0.82 & 0.16 & 74.8 & 158.6 & 1.88 & 0.37 & 1.75 & 24.8 & 52.6 & 0.62 & 0.12 & 0.65 \\
\hline & Thur AM & 3.40 & 0.67 & 0.62 & 0.12 & 65.6 & 138.9 & 1.54 & 0.30 & 1.42 & 21.7 & 46.1 & 0.51 & 0.10 & 0.53 \\
\hline & Thur PM & 3.84 & 0.76 & 0.70 & 0.14 & 108.7 & 230.2 & 1.79 & 0.35 & 1.66 & 36.0 & 76.3 & 0.59 & 0.12 & 0.62 \\
\hline \multirow[t]{4}{*}{ ORIS04 } & Wed AM & & & & & & & & & & & & & & \\
\hline & Wed PM & 3.98 & 0.78 & 0.69 & 0.14 & & & & & & & & & & \\
\hline & Thur AM & 5.68 & 1.12 & 0.98 & 0.19 & & & & & & & & & & \\
\hline & Thur PM & 5.55 & 1.09 & 0.96 & 0.19 & & & & & & & & & & \\
\hline \multirow[t]{4}{*}{ PABS03 } & Wed AM & 3.37 & 0.66 & 0.58 & 0.11 & 0.0 & 0.0 & 0.00 & 0.00 & 0.00 & 34.7 & 73.6 & 1.12 & 0.22 & 1.09 \\
\hline & Wed PM & 3.12 & 0.61 & 0.54 & 0.11 & 0.0 & 0.0 & 0.00 & 0.00 & 0.00 & 38.7 & 81.9 & 1.07 & 0.21 & 1.07 \\
\hline & Thur AM & 3.18 & 0.63 & 0.55 & 0.11 & 0.0 & 0.0 & 0.00 & 0.00 & 0.00 & 43.9 & 93.0 & 1.17 & 0.23 & 1.17 \\
\hline & Thur PM & 3.45 & 0.68 & 0.60 & 0.12 & 0.0 & 0.0 & 0.00 & 0.00 & 0.00 & 42.2 & 89.4 & 1.27 & 0.25 & 1.23 \\
\hline \multirow[t]{4}{*}{ PABS04 } & Wed AM & 4.88 & 0.96 & 0.69 & 0.14 & 8.5 & 17.9 & 0.63 & 0.12 & 0.60 & 2.5 & 5.3 & 0.19 & 0.04 & 0.21 \\
\hline & Wed PM & 4.82 & 0.95 & 0.69 & 0.13 & 9.0 & 19.1 & 0.61 & 0.12 & 0.58 & 2.7 & 5.6 & 0.18 & 0.04 & 0.20 \\
\hline & Thur AM & 4.55 & 0.90 & 0.65 & 0.13 & 7.5 & 16.0 & 0.58 & 0.11 & 0.54 & 2.3 & 4.8 & 0.17 & 0.03 & 0.19 \\
\hline & Thur PM & 4.74 & 0.93 & 0.67 & 0.13 & 9.2 & 19.5 & 0.61 & 0.12 & 0.58 & 2.7 & 5.8 & 0.18 & 0.04 & 0.20 \\
\hline \multirow[t]{4}{*}{ SCDW01 } & Wed AM & 5.88 & 1.16 & 0.83 & 0.16 & 18.5 & 39.2 & 1.42 & 0.28 & 1.42 & 5.9 & 12.4 & 0.45 & 0.09 & 0.51 \\
\hline & Wed PM & 4.97 & 0.98 & 0.70 & 0.14 & 18.3 & 38.7 & 1.24 & 0.24 & 1.24 & 5.8 & 12.2 & 0.39 & 0.08 & 0.45 \\
\hline & Thur AM & 5.46 & 1.08 & 0.77 & 0.15 & 18.1 & 38.4 & 1.30 & 0.26 & 1.30 & 5.7 & 12.1 & 0.41 & 0.08 & 0.47 \\
\hline & Thur PM & 4.68 & 0.92 & 0.66 & 0.13 & 15.9 & 33.6 & 1.03 & 0.20 & 1.03 & 5.0 & 10.6 & 0.33 & 0.06 & 0.37 \\
\hline \multirow[t]{4}{*}{ SCDW02 } & Wed AM & 7.58 & 1.49 & 1.31 & 0.26 & 26.1 & 55.4 & 1.38 & 0.27 & 1.15 & 8.7 & 18.4 & 0.46 & 0.09 & 0.43 \\
\hline & Wed PM & 8.18 & 1.61 & 1.42 & 0.28 & 25.9 & 54.9 & 1.53 & 0.30 & 1.28 & 8.6 & 18.2 & 0.51 & 0.10 & 0.48 \\
\hline & Thur AM & 7.39 & 1.45 & 1.28 & 0.25 & 23.9 & 50.7 & 1.41 & 0.28 & 1.18 & 7.9 & 16.8 & 0.47 & 0.09 & 0.44 \\
\hline & Thur PM & 7.69 & 1.51 & 1.33 & 0.26 & 22.6 & 47.9 & 1.19 & 0.23 & 0.99 & 7.5 & 15.9 & 0.39 & 0.08 & 0.37 \\
\hline \multirow[t]{4}{*}{ SDBW01 } & Wed AM & 3.87 & 0.76 & 0.55 & 0.11 & 43.1 & 91.3 & 1.77 & 0.35 & 1.96 & 13.6 & 28.9 & 0.56 & 0.11 & 0.71 \\
\hline & Wed PM & 4.15 & 0.82 & 0.59 & 0.12 & 64.6 & 136.8 & 2.14 & 0.42 & 2.37 & 20.4 & 43.3 & 0.68 & 0.13 & 0.86 \\
\hline & Thur AM & 3.95 & 0.78 & 0.56 & 0.11 & 56.1 & 119.0 & 2.07 & 0.41 & 2.29 & 17.8 & 37.6 & 0.65 & 0.13 & 0.83 \\
\hline & Thur PM & 4.09 & 0.80 & 0.58 & 0.11 & 60.6 & 128.4 & 2.23 & 0.44 & 2.47 & 19.2 & 40.6 & 0.71 & 0.14 & 0.89 \\
\hline
\end{tabular}




\begin{tabular}{|c|c|c|c|c|c|c|c|c|c|c|c|c|c|c|c|}
\hline \multirow{3}{*}{$\begin{array}{l}\text { Study Space } \\
\text { ID }\end{array}$} & \multirow[b]{3}{*}{ Period } & \multicolumn{4}{|c|}{ SUPPLY AIRFLOW } & \multicolumn{10}{|c|}{ OUTDOOR AIRFLOW } \\
\hline & & \multicolumn{2}{|c|}{$\begin{array}{c}\text { Volumetric supply } \\
\text { airflow }\end{array}$} & \multicolumn{2}{|c|}{$\begin{array}{l}\text { Uncertainty in } \\
\text { supply airflow }\end{array}$} & \multicolumn{5}{|c|}{ Volumetric } & \multicolumn{5}{|c|}{ Uncertainty in volumetric $\mathrm{OA}$} \\
\hline & & $\mathrm{L} / \mathrm{s} \cdot \mathrm{m}^{2}$ & $\mathrm{cfm} / \mathrm{ft}^{2}$ & $\mathrm{~L} / \mathrm{s} \bullet \mathrm{m}^{2}$ & $\mathrm{cfm} / \mathrm{ft}^{2}$ & $\mathrm{~L} / \mathrm{s} \bullet$ person & $\mathrm{cfm} /$ person & $\mathrm{L} / \mathrm{s} \cdot \mathrm{m}^{2}$ & $\mathrm{cfm} / \mathrm{ft}^{2}$ & $\mathrm{~h}^{-1}$ & $\mathrm{~L} / \mathrm{s} \bullet$ person & $\mathrm{cfm} /$ person & $\mathrm{L} / \mathrm{s} \cdot \mathrm{m}^{2}$ & $\mathrm{cfm} / \mathrm{ft}^{2}$ & $\mathrm{~h}^{-1}$ \\
\hline \multirow[t]{4}{*}{ SDBW02 } & Wed AM & 3.66 & 0.72 & 0.63 & 0.12 & 49.9 & 105.6 & 1.62 & 0.32 & 1.80 & 16.5 & 35.0 & 0.54 & 0.11 & 0.67 \\
\hline & Wed PM & 3.34 & 0.66 & 0.58 & 0.11 & 53.3 & 112.9 & 0.98 & 0.19 & 1.08 & 17.7 & 37.5 & 0.32 & 0.06 & 0.41 \\
\hline & Thur AM & 3.64 & 0.72 & 0.63 & 0.12 & 35.3 & 74.8 & 1.03 & 0.20 & 1.14 & 11.7 & 24.8 & 0.34 & 0.07 & 0.43 \\
\hline & Thur PM & 3.37 & 0.66 & 0.58 & 0.12 & 31.7 & 67.3 & 0.79 & 0.16 & 0.88 & 10.5 & 22.3 & 0.26 & 0.05 & 0.33 \\
\hline \multirow[t]{4}{*}{ SDBW04 } & Wed AM & 11.17 & 2.20 & 1.58 & 0.31 & 47.1 & 99.7 & 2.39 & 0.47 & 2.68 & 56.4 & 119.6 & 2.87 & 0.57 & 3.24 \\
\hline & Wed PM & 9.48 & 1.87 & 1.34 & 0.26 & 55.6 & 117.8 & 1.89 & 0.37 & 2.11 & 73.0 & 154.6 & 2.48 & 0.49 & 2.79 \\
\hline & Thur AM & 9.13 & 1.80 & 1.29 & 0.25 & 44.0 & 93.2 & 1.78 & 0.35 & 1.99 & 59.1 & 125.1 & 2.39 & 0.47 & 2.70 \\
\hline & Thur PM & 9.06 & 1.78 & 1.28 & 0.25 & 39.3 & 83.2 & 1.96 & 0.39 & 2.19 & 46.5 & 98.5 & 2.32 & 0.46 & 2.62 \\
\hline \multirow[t]{4}{*}{ TNDS05 } & Wed AM & 2.08 & 0.41 & 0.32 & 0.06 & 59.1 & 125.1 & 2.08 & 0.41 & 2.32 & 16.7 & 35.3 & 0.59 & 0.12 & 0.77 \\
\hline & Wed PM & 2.27 & 0.45 & 0.35 & 0.07 & 89.6 & 189.8 & 2.27 & 0.45 & 2.54 & 25.7 & 54.5 & 0.65 & 0.13 & 0.85 \\
\hline & Thur AM & 2.16 & 0.42 & 0.34 & 0.07 & 65.3 & 138.3 & 2.16 & 0.42 & 2.41 & 18.7 & 39.7 & 0.62 & 0.12 & 0.81 \\
\hline & Thur PM & 2.04 & 0.40 & 0.32 & 0.06 & 82.7 & 175.3 & 2.04 & 0.40 & 2.28 & 23.7 & 50.2 & 0.58 & 0.11 & 0.76 \\
\hline \multirow[t]{4}{*}{ TNDS06 } & Wed AM & 2.64 & 0.52 & 0.46 & 0.09 & 17.3 & 36.7 & 0.56 & 0.11 & 0.51 & 21.0 & 44.5 & 0.68 & 0.13 & 0.62 \\
\hline & Wed PM & 2.25 & 0.44 & 0.39 & 0.08 & 6.7 & 14.2 & 0.19 & 0.04 & 0.17 & 22.9 & 48.5 & 0.66 & 0.13 & 0.59 \\
\hline & Thur AM & 2.07 & 0.41 & 0.36 & 0.07 & 5.4 & 11.5 & 0.27 & 0.05 & 0.24 & 11.7 & 24.8 & 0.58 & 0.11 & 0.52 \\
\hline & Thur PM & 2.13 & 0.42 & 0.37 & 0.07 & 1.3 & 2.8 & 0.05 & 0.01 & 0.04 & 18.3 & 38.7 & 0.66 & 0.13 & 0.59 \\
\hline \multirow[t]{4}{*}{ TNDS07 } & Wed AM & 5.55 & 1.09 & 0.79 & 0.15 & 3.1 & 6.6 & 0.13 & 0.03 & 0.14 & 1.0 & 2.1 & 0.04 & 0.01 & 0.05 \\
\hline & Wed PM & 5.36 & 1.06 & 0.76 & 0.15 & 2.6 & 5.5 & 0.16 & 0.03 & 0.17 & 0.8 & 1.7 & 0.05 & 0.01 & 0.06 \\
\hline & Thur AM & 5.55 & 1.09 & 0.79 & 0.15 & 2.6 & 5.6 & 0.17 & 0.03 & 0.18 & 0.8 & 1.8 & 0.05 & 0.01 & 0.06 \\
\hline & Thur PM & 5.61 & 1.10 & 0.79 & 0.16 & 14.6 & 31.0 & 0.89 & 0.18 & 0.96 & 4.6 & 9.8 & 0.28 & 0.06 & 0.35 \\
\hline \multirow[t]{4}{*}{ TNFS08 } & Wed AM & 3.59 & 0.71 & 0.51 & 0.10 & 14.5 & 30.8 & 0.80 & 0.16 & 0.86 & 3.5 & 7.4 & 0.19 & 0.04 & 0.26 \\
\hline & Wed PM & 3.63 & 0.71 & 0.52 & 0.10 & 20.9 & 44.3 & 0.86 & 0.17 & 0.93 & 5.3 & 11.1 & 0.22 & 0.04 & 0.28 \\
\hline & Thur AM & 3.81 & 0.75 & 0.54 & 0.11 & 15.7 & 33.3 & 0.87 & 0.17 & 0.93 & 3.9 & 8.3 & 0.22 & 0.04 & 0.28 \\
\hline & Thur PM & 4.34 & 0.85 & 0.60 & 0.12 & 15.3 & 32.4 & 0.83 & 0.16 & 0.89 & 3.8 & 8.1 & 0.21 & 0.04 & 0.27 \\
\hline \multirow[t]{4}{*}{ TNFS09 } & Wed AM & 3.29 & 0.65 & 0.48 & 0.10 & 10.7 & 22.8 & 0.93 & 0.18 & 0.96 & 5.9 & 12.5 & 0.51 & 0.10 & 0.55 \\
\hline & Wed PM & 3.18 & 0.63 & 0.46 & 0.09 & 12.2 & 25.8 & 0.76 & 0.15 & 0.78 & 7.9 & 16.7 & 0.49 & 0.10 & 0.53 \\
\hline & Thur AM & 2.71 & 0.53 & 0.40 & 0.08 & 7.5 & 15.8 & 0.58 & 0.11 & 0.60 & 6.2 & 13.2 & 0.49 & 0.10 & 0.51 \\
\hline & Thur PM & 2.86 & 0.56 & 0.42 & 0.08 & 8.4 & 17.9 & 0.65 & 0.13 & 0.66 & 6.2 & 13.2 & 0.48 & 0.09 & 0.50 \\
\hline \multirow[t]{4}{*}{ TNFS10 } & Wed AM & 6.20 & 1.22 & 1.07 & 0.21 & 84.9 & 179.9 & 4.27 & 0.84 & 3.53 & 20.7 & 43.9 & 1.04 & 0.21 & 1.06 \\
\hline & Wed PM & 7.31 & 1.44 & 1.27 & 0.25 & 75.3 & 159.5 & 3.92 & 0.77 & 3.24 & 26.4 & 55.8 & 1.37 & 0.27 & 1.27 \\
\hline & Thur AM & 6.90 & 1.36 & 1.20 & 0.24 & 103.9 & 220.1 & 4.85 & 0.96 & 4.02 & 24.6 & 52.2 & 1.15 & 0.23 & 1.18 \\
\hline & Thur PM & 6.08 & 1.20 & 1.05 & 0.21 & 81.0 & 171.6 & 4.28 & 0.84 & 3.55 & 19.2 & 40.6 & 1.01 & 0.20 & 1.04 \\
\hline \multirow[t]{4}{*}{ TXFS01 } & Wed AM & 3.58 & 0.71 & 0.62 & 0.12 & & & & & & & & & & \\
\hline & Wed PM & 4.39 & 0.86 & 0.76 & 0.15 & 5.9 & 12.4 & 0.20 & 0.04 & 0.17 & 1.9 & 4.1 & 0.07 & 0.01 & 0.06 \\
\hline & Thur AM & 4.33 & 0.85 & 0.75 & 0.15 & 4.6 & 9.7 & 0.19 & 0.04 & 0.15 & 1.5 & 3.2 & 0.06 & 0.01 & 0.06 \\
\hline & Thur PM & 4.46 & 0.88 & 0.77 & 0.15 & 6.5 & 13.8 & 0.18 & 0.04 & 0.15 & 2.2 & 4.6 & 0.06 & 0.01 & 0.06 \\
\hline \multirow[t]{4}{*}{ TXFS02 } & Wed AM & 6.64 & 1.31 & 0.81 & 0.16 & 10.8 & 22.9 & 0.31 & 0.06 & 0.35 & 2.5 & 5.4 & 0.07 & 0.01 & 0.10 \\
\hline & Wed PM & 6.47 & 1.27 & 0.79 & 0.16 & 12.9 & 27.2 & 0.31 & 0.06 & 0.35 & 3.0 & 6.4 & 0.07 & 0.01 & 0.10 \\
\hline & Thur AM & 7.63 & 1.50 & 0.93 & 0.18 & 9.5 & 20.1 & 0.30 & 0.06 & 0.34 & 2.2 & 4.7 & 0.07 & 0.01 & 0.10 \\
\hline & Thur PM & 6.71 & 1.32 & 0.82 & 0.16 & 14.7 & 31.2 & 0.31 & 0.06 & 0.35 & 3.5 & 7.3 & 0.07 & 0.01 & 0.10 \\
\hline
\end{tabular}




\begin{tabular}{|c|c|c|c|c|c|c|c|c|c|c|c|c|c|c|c|}
\hline \multirow{3}{*}{$\begin{array}{c}\text { Study Space } \\
\text { ID }\end{array}$} & \multirow[b]{3}{*}{ Period } & \multicolumn{4}{|c|}{ SUPPLY AIRFLOW } & \multicolumn{10}{|c|}{ OUTDOOR AIRFLOW } \\
\hline & & \multicolumn{2}{|c|}{$\begin{array}{c}\text { Volumetric supply } \\
\text { airflow }\end{array}$} & \multicolumn{2}{|c|}{$\begin{array}{l}\text { Uncertainty in } \\
\text { supply airflow }\end{array}$} & \multicolumn{5}{|c|}{ Volumetric } & \multicolumn{5}{|c|}{ Uncertainty in volumetric $\mathrm{OA}$} \\
\hline & & $\mathrm{L} / \mathrm{s} \cdot \mathrm{m}^{2}$ & $\mathrm{cfm} / \mathrm{ft}^{2}$ & $\mathrm{~L} / \mathrm{s} \cdot \mathrm{m}^{2}$ & $\mathrm{cfm} / \mathrm{ft}^{2}$ & $\mathrm{~L} / \mathrm{s} \cdot$ person & cfm/person & $\mathrm{L} / \mathrm{s} \cdot \mathrm{m}^{2}$ & $\mathrm{cfm} / \mathrm{ft}^{2}$ & $\mathrm{~h}^{-1}$ & L/s•person & cfm/person & $\mathrm{L} / \mathrm{s} \cdot \mathrm{m}^{2}$ & $\mathrm{cfm} / \mathrm{ft}^{2}$ & $\mathrm{~h}^{-1}$ \\
\hline \multirow[t]{4}{*}{ TXFS07 } & Wed AM & 4.72 & 0.93 & 0.82 & 0.16 & 7.0 & 14.8 & 0.60 & 0.12 & 0.69 & 2.3 & \begin{tabular}{|l|}
4.9 \\
\end{tabular} & 0.20 & 0.04 & 0.26 \\
\hline & Wed PM & 4.72 & 0.93 & 0.82 & 0.16 & 7.9 & 16.7 & 0.67 & 0.13 & 0.77 & 2.6 & 5.5 & 0.22 & 0.04 & 0.29 \\
\hline & \begin{tabular}{|l|} 
Thur AM \\
\end{tabular} & 4.39 & 0.86 & 0.76 & 0.15 & 7.5 & 15.8 & 0.63 & 0.12 & 0.72 & 2.5 & 5.2 & 0.21 & 0.04 & 0.27 \\
\hline & Thur PM & 4.12 & 0.81 & 0.71 & 0.14 & 6.7 & 14.2 & 0.65 & 0.13 & 0.75 & 2.2 & 4.7 & 0.22 & 0.04 & 0.28 \\
\hline \multirow[t]{4}{*}{ TXFS08 } & Wed AM & 4.45 & 0.88 & 0.64 & 0.13 & 6.0 & 12.7 & 0.22 & 0.04 & 0.25 & 1.5 & 3.2 & 0.05 & 0.01 & 0.08 \\
\hline & Wed PM & 4.89 & 0.96 & 0.71 & 0.14 & 6.6 & 13.9 & 0.24 & 0.05 & 0.27 & 1.7 & 3.5 & 0.06 & 0.01 & 0.08 \\
\hline & Thur AM & 4.54 & 0.89 & 0.66 & 0.13 & 8.9 & 18.8 & 0.25 & 0.05 & 0.29 & 2.3 & 4.8 & 0.07 & 0.01 & 0.09 \\
\hline & Thur PM & 4.82 & 0.95 & 0.70 & 0.14 & 7.2 & 15.2 & 0.27 & 0.05 & 0.31 & 1.9 & 3.9 & 0.07 & 0.01 & 0.10 \\
\hline \multirow[t]{4}{*}{ TXFS09 } & Wed AM & 4.30 & 0.85 & 0.53 & 0.10 & 28.3 & 59.9 & 0.82 & 0.16 & 0.78 & 6.6 & 14.0 & 0.19 & 0.04 & 0.23 \\
\hline & Wed PM & 4.39 & 0.86 & 0.54 & 0.11 & 32.6 & 69.2 & 0.80 & 0.16 & 0.76 & 7.7 & 16.2 & 0.19 & 0.04 & 0.22 \\
\hline & Thur AM & 4.34 & 0.86 & 0.53 & 0.10 & 31.9 & 67.6 & 0.83 & 0.16 & 0.80 & 7.5 & 15.8 & 0.19 & 0.04 & 0.23 \\
\hline & Thur PM & 4.35 & 0.86 & 0.53 & 0.10 & 29.9 & 63.4 & 0.84 & 0.17 & 0.81 & 7.0 & 14.9 & 0.20 & 0.04 & 0.24 \\
\hline \multirow[t]{4}{*}{ TXFW05 } & Wed AM & 1.98 & 0.39 & 0.34 & 0.07 & 13.5 & 28.5 & 0.51 & 0.10 & 0.58 & 12.8 & 27.2 & 0.49 & 0.10 & 0.56 \\
\hline & Wed PM & 1.91 & 0.38 & 0.33 & 0.07 & 11.6 & 24.6 & 0.47 & 0.09 & 0.54 & 11.6 & 24.7 & 0.48 & 0.09 & 0.55 \\
\hline & Thur AM & 2.34 & 0.46 & 0.40 & 0.08 & 33.0 & 70.0 & 1.37 & 0.27 & 1.56 & 10.1 & 21.5 & 0.42 & 0.08 & 0.55 \\
\hline & Thur PM & 2.34 & 0.46 & 0.41 & 0.08 & 38.9 & 82.4 & 1.46 & 0.29 & 1.66 & 10.9 & 23.1 & 0.41 & 0.08 & 0.55 \\
\hline \multirow[t]{4}{*}{ TXFW06 } & Wed AM & 3.39 & 0.67 & 0.59 & 0.12 & 143.9 & 304.8 & 3.41 & 0.67 & 3.87 & 47.7 & 101.1 & 1.13 & 0.22 & 1.45 \\
\hline & Wed PM & 2.85 & 0.56 & 0.49 & 0.10 & 130.9 & 277.4 & 2.85 & 0.56 & 3.23 & 43.4 & 92.0 & 0.94 & 0.19 & 1.21 \\
\hline & Thur AM & 2.91 & 0.57 & 0.50 & 0.10 & 116.4 & 246.7 & 2.91 & 0.57 & 3.30 & 38.6 & 81.8 & 0.96 & 0.19 & 1.24 \\
\hline & Thur PM & 3.26 & 0.64 & 0.56 & 0.11 & 201.1 & 426.0 & 3.26 & 0.64 & 3.70 & 66.7 & 141.3 & 1.08 & 0.21 & 1.39 \\
\hline \multirow[t]{4}{*}{ WAIW03 } & Wed AM & 1.54 & 0.30 & 0.22 & 0.04 & 45.2 & 95.9 & 1.56 & 0.31 & 1.60 & 14.3 & 30.3 & 0.49 & 0.10 & 0.58 \\
\hline & Wed PM & 2.14 & 0.42 & 0.30 & 0.06 & 68.4 & 145.0 & 1.89 & 0.37 & 1.95 & 21.6 & 45.8 & 0.60 & 0.12 & 0.70 \\
\hline & Thur AM & 1.78 & 0.35 & 0.25 & 0.05 & 51.8 & 109.7 & 1.81 & 0.36 & 1.86 & 16.4 & 34.7 & 0.57 & 0.11 & 0.67 \\
\hline & Thur PM & 2.11 & 0.41 & 0.30 & 0.06 & 70.2 & 148.6 & 1.94 & 0.38 & 2.00 & 22.2 & 47.0 & 0.61 & 0.12 & 0.72 \\
\hline \multirow[t]{4}{*}{ WAIW04 } & Wed AM & 1.29 & 0.25 & 0.18 & 0.04 & 58.8 & 124.5 & 1.25 & 0.25 & 1.20 & 18.6 & 39.4 & 0.40 & 0.08 & 0.43 \\
\hline & Wed PM & 1.29 & 0.25 & 0.18 & 0.04 & 48.6 & 102.9 & 1.28 & 0.25 & 1.22 & 15.4 & 32.6 & 0.40 & 0.08 & 0.44 \\
\hline & Thur AM & 1.29 & 0.25 & 0.18 & 0.04 & 49.7 & 105.3 & 1.26 & 0.25 & 1.21 & 15.7 & 33.3 & 0.40 & 0.08 & 0.44 \\
\hline & \begin{tabular}{|l|} 
Thur PM \\
\end{tabular} & 1.26 & 0.25 & 0.18 & 0.04 & 51.4 & 108.9 & 1.26 & 0.25 & 1.21 & 16.2 & 34.4 & 0.40 & 0.08 & 0.44 \\
\hline \multicolumn{2}{|l|}{$\#$ of values } & 384 & & & & 367 & & 369 & & 369 & & & & & \\
\hline \multicolumn{2}{|l|}{ Mean } & 5.12 & 1.01 & 0.80 & 0.16 & 49.4 & 104.7 & 1.87 & 0.37 & 1.83 & 20.5 & 43.4 & 0.78 & 0.15 & 0.83 \\
\hline \multicolumn{2}{|l|}{ StdDev } & 3.02 & 0.59 & 0.45 & 0.09 & 53.6 & 113.5 & 2.08 & 0.41 & 2.07 & 20.6 & 43.6 & 0.82 & 0.16 & 0.86 \\
\hline \multicolumn{2}{|l|}{ Minimum } & 0.88 & 0.17 & 0.13 & 0.03 & 0.0 & 0.0 & 0.00 & 0.00 & 0.00 & 0.7 & 1.5 & 0.02 & 0.00 & 0.02 \\
\hline \multicolumn{2}{|l|}{ 10th percentile } & 2.16 & 0.43 & 0.32 & 0.06 & 6.3 & 13.3 & 0.24 & 0.05 & 0.22 & 2.4 & 5.0 & 0.09 & 0.02 & 0.10 \\
\hline \multicolumn{2}{|l|}{25 th percentile } & 2.99 & 0.59 & 0.46 & 0.09 & 12.6 & 26.8 & 0.50 & 0.10 & 0.47 & 5.7 & 12.0 & 0.19 & 0.04 & 0.21 \\
\hline Median & & 4.69 & 0.92 & 0.74 & 0.15 & 29.9 & 63.4 & 1.03 & 0.20 & 0.98 & 13.0 & 27.5 & 0.48 & 0.09 & 0.53 \\
\hline 75 th percentile & & 6.25 & 1.23 & 1.01 & 0.20 & 65.9 & 139.6 & 2.30 & 0.45 & 2.46 & 28.0 & 59.4 & 1.13 & 0.22 & 1.24 \\
\hline 90th percentile & & 8.47 & 1.67 & 1.34 & 0.26 & 115.6 & 244.9 & 4.64 & 0.91 & 4.46 & 50.9 & 107.8 & 1.88 & 0.37 & 1.88 \\
\hline Maximum & & 21.11 & 4.15 & 2.99 & 0.59 & 310.1 & 657.0 & 12.31 & 2.42 & 13.23 & 102.8 & 217.9 & 5.18 & 1.02 & 5.13 \\
\hline
\end{tabular}




\begin{tabular}{|c|c|c|c|c|c|c|c|c|c|c|c|c|c|c|c|}
\hline \multirow{3}{*}{$\begin{array}{c}\text { Study Space } \\
\text { ID }\end{array}$} & \multirow[b]{3}{*}{ Period } & \multicolumn{14}{|c|}{ OUTDOOR AIRFLOW } \\
\hline & & \multicolumn{5}{|c|}{$\mathrm{CO}_{2}$ Ratio } & \multicolumn{5}{|c|}{ Uncertainty in $\mathrm{CO}_{2}$ ratio $\mathrm{OA}$} & \multicolumn{2}{|c|}{ Peak $\mathrm{CO}_{2}$} & \multicolumn{2}{|c|}{$\begin{array}{c}\text { Uncertainty in peak } \mathrm{CO}_{2} \\
\mathrm{OA}\end{array}$} \\
\hline & & $\mathrm{L} / \mathrm{s} \bullet$ person & $\mathrm{cfm} /$ person & $\mathrm{L} / \mathrm{s} \cdot \mathrm{m}^{2}$ & $\mathrm{cfm} / \mathrm{ft}^{2}$ & $\mathrm{~h}^{-1}$ & L/s•person & $\mathrm{cfm} /$ person & $\mathrm{L} / \mathrm{s} \cdot \mathrm{m}^{2}$ & $\mathrm{cfm} / \mathrm{ft}^{2}$ & $\mathrm{~h}^{-1}$ & $\mathrm{~L} / \mathrm{s}$ •person & cfm/person & $\mathrm{L} / \mathrm{s} \cdot$ person & $\mathrm{cfm} /$ person \\
\hline \multirow{3}{*}{ ARFW01 } & Wed PM & 6.9 & 14.6 & 0.21 & 0.04 & 0.20 & 37.4 & 79.2 & 1.13 & 0.22 & 1.07 & 13.3 & 28.1 & 2.3 & 4.9 \\
\hline & Thur AM & 22.2 & 46.9 & 0.87 & 0.17 & 0.82 & 28.6 & 60.6 & 1.12 & 0.22 & 1.07 & 11.6 & 24.6 & 1.9 & 3.9 \\
\hline & Thur PM & 21.8 & 46.3 & 0.79 & 0.15 & 0.74 & 29.3 & 62.2 & 1.06 & 0.21 & 1.01 & 11.1 & 23.5 & 1.7 & 3.7 \\
\hline \multirow{3}{*}{ ARFW02 } & Wed AM & 68.0 & 144.1 & 1.81 & 0.36 & 1.44 & 133.2 & 282.1 & 3.54 & 0.70 & 2.83 & 22.0 & 46.7 & 5.7 & 12.0 \\
\hline & Thur AM & & & & & & & & & & & 12.4 & 26.3 & 2.1 & 4.4 \\
\hline & Thur PM & 78.2 & 165.8 & 1.87 & 0.37 & 1.49 & 85.4 & 180.9 & 2.04 & 0.40 & 1.64 & 25.0 & 53.0 & 7.2 & 15.2 \\
\hline \multirow[t]{4}{*}{ ARFW03 } & Wed AM & 9.6 & 20.4 & 0.43 & 0.08 & 0.34 & 19.8 & 41.9 & 0.89 & 0.17 & 0.70 & 11.0 & 23.3 & 1.7 & 3.6 \\
\hline & Wed PM & 2.9 & 6.1 & 0.11 & 0.02 & 0.09 & 24.3 & 51.4 & 0.97 & 0.19 & 0.76 & 11.8 & 25.1 & 1.9 & 4.1 \\
\hline & Thur AM & 5.0 & 10.5 & 0.25 & 0.05 & 0.20 & 15.4 & 32.5 & 0.78 & 0.15 & 0.62 & 11.1 & 23.5 & 1.7 & 3.6 \\
\hline & Thur PM & 15.4 & 32.7 & 0.66 & 0.13 & 0.53 & 23.4 & 49.5 & 1.01 & 0.20 & 0.80 & 10.4 & 22.0 & 1.6 & 3.3 \\
\hline \multirow[t]{3}{*}{ AZHS02 } & Wed AM & 45.3 & 96.0 & 2.44 & 0.48 & 2.40 & 30.6 & 64.8 & 1.65 & 0.32 & 1.67 & 27.0 & 57.1 & 8.5 & 18.0 \\
\hline & Wed PM & 103.0 & 218.1 & 2.68 & 0.53 & 2.64 & 119.2 & 252.5 & 3.10 & 0.61 & 3.09 & 35.2 & 74.6 & 14.2 & 30.1 \\
\hline & Thur AM & 23.1 & 48.9 & 1.44 & 0.28 & 1.42 & 49.9 & 105.8 & 3.12 & 0.61 & 3.08 & 25.5 & 54.1 & 7.7 & 16.3 \\
\hline \multirow[t]{4}{*}{ AZHS04 } & Wed AM & 9.7 & 20.6 & 0.70 & 0.14 & 0.72 & 11.6 & 24.6 & 0.84 & 0.17 & 0.87 & 7.3 & 15.5 & 0.9 & 2.0 \\
\hline & Wed PM & 4.5 & 9.5 & 0.15 & 0.03 & 0.15 & 27.5 & 58.3 & 0.91 & 0.18 & 0.94 & 8.2 & 17.3 & 1.1 & 2.3 \\
\hline & Thur AM & 196.0 & 415.2 & 4.50 & 0.89 & 4.63 & 195.2 & 413.5 & 4.48 & 0.88 & 4.68 & & & & \\
\hline & Thur PM & 23.6 & 50.0 & 0.67 & 0.13 & 0.69 & 25.2 & 53.4 & 0.72 & 0.14 & 0.75 & 10.5 & 22.3 & 1.6 & 3.4 \\
\hline \multirow[t]{4}{*}{ AZHW10 } & Wed AM & 44.0 & 93.2 & 1.26 & 0.25 & 1.36 & 95.2 & 201.6 & 2.73 & 0.54 & 2.94 & 20.7 & 43.9 & 5.2 & 11.0 \\
\hline & Wed PM & 204.3 & 432.8 & 4.59 & 0.90 & 4.93 & 246.0 & 521.1 & 5.53 & 1.09 & 6.00 & 31.1 & 65.8 & 11.2 & 23.6 \\
\hline & Thur AM & 189.8 & 402.2 & 5.15 & 1.01 & 5.53 & 315.3 & 667.9 & 8.55 & 1.68 & 9.24 & 33.0 & 70.0 & 12.6 & 26.6 \\
\hline & Thur PM & 200.9 & 425.6 & 5.45 & 1.07 & 5.86 & 302.2 & 640.2 & 8.20 & 1.61 & 8.87 & 26.1 & 55.4 & 8.0 & 17.0 \\
\hline \multirow[t]{4}{*}{ AZHW11 } & Wed AM & 21.3 & 45.1 & 0.85 & 0.17 & 0.83 & 30.0 & 63.6 & 1.20 & 0.24 & 1.18 & 13.7 & 29.0 & 2.5 & 5.3 \\
\hline & Wed PM & 54.1 & 114.7 & 1.72 & 0.34 & 1.68 & 77.6 & 164.3 & 2.47 & 0.49 & 2.43 & 22.3 & 47.3 & 6.0 & 12.7 \\
\hline & Thur AM & 35.2 & 74.5 & 1.20 & 0.24 & 1.17 & 54.3 & 115.0 & 1.85 & 0.36 & 1.82 & 15.8 & 33.5 & 3.2 & 6.8 \\
\hline & Thur PM & 33.1 & 70.1 & 1.00 & 0.20 & 0.98 & 74.2 & 157.1 & 2.25 & 0.44 & 2.21 & 15.8 & 33.4 & 3.2 & 6.7 \\
\hline \multirow[t]{4}{*}{ AZHW12 } & Wed AM & & & & & & & & & & & 14.3 & 30.4 & 2.7 & 5.7 \\
\hline & Wed PM & & & & & & & & & & & 14.1 & 29.8 & 2.6 & 5.5 \\
\hline & Thur AM & 8.4 & 17.8 & 0.27 & 0.05 & 0.27 & 14.3 & 30.4 & 0.47 & 0.09 & 0.46 & 15.6 & 33.0 & 3.1 & 6.6 \\
\hline & Thur PM & 11.3 & 23.9 & 0.33 & 0.07 & 0.33 & 13.0 & 27.5 & 0.38 & 0.08 & 0.38 & 11.9 & 25.2 & 2.0 & 4.2 \\
\hline \multirow[t]{3}{*}{ CAES17 } & Wed AM & 86.6 & 183.5 & 4.90 & 0.96 & 4.82 & 126.9 & 268.8 & 7.17 & 1.41 & 7.10 & 15.2 & 32.1 & 3.0 & 6.3 \\
\hline & Wed PM & 88.4 & 187.4 & 4.68 & 0.92 & 4.60 & 129.5 & 274.4 & 6.86 & 1.35 & 6.79 & 10.7 & 22.6 & 1.7 & 3.5 \\
\hline & Thur AM & 69.6 & 147.5 & 3.52 & 0.69 & 3.46 & 199.9 & 423.6 & 10.10 & 1.99 & 9.95 & 16.7 & 35.3 & 3.5 & 7.4 \\
\hline \multirow{3}{*}{ CAEW07 } & Wed PM & 213.1 & 451.6 & 6.42 & 1.26 & 5.72 & 436.1 & 923.9 & 13.15 & 2.59 & 11.75 & 10.7 & 22.7 & 1.7 & 3.5 \\
\hline & Thur AM & 45.4 & 96.2 & 1.17 & 0.23 & 1.05 & 164.7 & 349.0 & 4.26 & 0.84 & 3.80 & 68.9 & 146.0 & 53.3 & 112.9 \\
\hline & Thur PM & 206.8 & 438.2 & 6.23 & 1.23 & 5.55 & 762.4 & 1615.1 & 22.98 & 4.52 & 20.50 & & & & \\
\hline
\end{tabular}




\begin{tabular}{|c|c|c|c|c|c|c|c|c|c|c|c|c|c|c|c|}
\hline \multirow{3}{*}{$\begin{array}{l}\text { Study Space } \\
\text { ID }\end{array}$} & \multirow[b]{3}{*}{ Period } & \multicolumn{14}{|c|}{ OUTDOOR AIRFLOW } \\
\hline & & \multicolumn{5}{|c|}{$\mathrm{CO}_{2}$ Ratio } & \multicolumn{5}{|c|}{ Uncertainty in $\mathrm{CO}_{2}$ ratio $\mathrm{OA}$} & \multicolumn{2}{|c|}{ Peak $\mathrm{CO}_{2}$} & \multicolumn{2}{|c|}{$\begin{array}{c}\text { Uncertainty in peak } \mathrm{CO}_{2} \\
\mathrm{OA}\end{array}$} \\
\hline & & $\mathrm{L} / \mathrm{s} \bullet$ person & cfm/person & $\mathrm{L} / \mathrm{s} \cdot \mathrm{m}^{2}$ & $\mathrm{cfm} / \mathrm{ft}^{2}$ & $\mathrm{~h}^{-1}$ & $\mathrm{~L} / \mathrm{s} \cdot$ person & cfm/person & $\mathrm{L} / \mathrm{s} \cdot \mathrm{m}^{2}$ & $\mathrm{cfm} / \mathrm{ft}^{2}$ & $\mathrm{~h}^{-1}$ & $L / s \bullet$ person & cfm/person & $\mathrm{L} / \mathrm{s} \cdot$ person & cfm/person \\
\hline \multirow[t]{4}{*}{\begin{tabular}{|l} 
CAEW09 \\
\end{tabular}} & Wed AM & 14.2 & 30.0 & 0.21 & 0.04 & 0.19 & 101.0 & 214.0 & 1.52 & 0.30 & 1.36 & & & & \\
\hline & Wed PM & 22.5 & 47.6 & 0.69 & 0.14 & 0.61 & 36.9 & 78.2 & 1.13 & 0.22 & 1.01 & 17.4 & 36.8 & 3.8 & 8.0 \\
\hline & Thur AM & 62.8 & 133.1 & 0.96 & 0.19 & 0.85 & 248.6 & 526.6 & 3.78 & 0.74 & 3.37 & & & & \\
\hline & Thur PM & 21.6 & 45.7 & 0.50 & 0.10 & 0.44 & 37.0 & 78.3 & 0.85 & 0.17 & 0.76 & 19.0 & 40.2 & 4.4 & 9.4 \\
\hline \multirow[t]{4}{*}{ CAJS01 } & Wed AM & & & & & & & & & & & & & & \\
\hline & Wed PM & & & & & & & & & & & & & & \\
\hline & \begin{tabular}{|l} 
Thur AM \\
\end{tabular} & 21.2 & 45.0 & 0.67 & 0.13 & 0.62 & 27.7 & 58.6 & 0.79 & 0.16 & 0.82 & & & & \\
\hline & Thur PM & 35.3 & 74.7 & 1.00 & 0.20 & 0.93 & 51.4 & 109.0 & 1.33 & 0.26 & 1.37 & & & & \\
\hline \multirow[t]{4}{*}{ CAJS02 } & Wed AM & & & 0.00 & 0.00 & 0.00 & & & 82.69 & 16.27 & 88.84 & 61.8 & 131.0 & 42.9 & 91.0 \\
\hline & Wed PM & 224.9 & 476.5 & 10.89 & 2.14 & 11.70 & 900.2 & 1907.2 & 43.59 & 8.58 & 46.88 & 32.8 & 69.5 & 12.4 & 26.3 \\
\hline & Thur AM & 91.7 & 194.3 & 4.66 & 0.92 & 5.01 & 349.4 & 740.2 & 17.75 & 3.49 & 19.09 & 79.3 & 167.9 & 70.3 & 149.0 \\
\hline & Thur PM & 87.3 & 184.8 & 5.06 & 1.00 & 5.43 & 281.6 & 596.6 & 16.32 & 3.21 & 17.56 & & & & \\
\hline \multirow[t]{4}{*}{ CAJS03 } & Wed AM & 18.4 & 38.9 & 0.58 & 0.11 & 0.62 & 327.9 & 694.8 & 10.30 & 2.03 & 11.07 & 74.8 & 158.5 & 62.7 & 132.8 \\
\hline & Wed PM & 84.8 & 179.6 & 3.74 & 0.74 & 4.02 & 224.5 & 475.7 & 9.90 & 1.95 & 10.66 & 23.9 & 50.7 & 6.8 & 14.4 \\
\hline & Thur AM & 55.4 & 117.3 & 2.07 & 0.41 & 2.23 & 218.1 & 462.0 & 8.16 & 1.61 & 8.78 & 87.1 & 184.6 & 84.9 & 179.9 \\
\hline & Thur PM & 68.2 & 144.6 & 2.78 & 0.55 & 2.99 & 193.7 & 410.4 & 7.90 & 1.55 & 8.50 & & & & \\
\hline \multirow[t]{4}{*}{ CAJS21 } & Wed AM & & & & & & & & & & & 25.4 & 53.8 & 7.4 & 15.7 \\
\hline & Wed PM & & & & & & & & & & & 25.6 & 54.2 & 10.3 & 21.9 \\
\hline & Thur AM & & & & & & & & & & & 31.7 & 67.2 & 11.3 & 23.9 \\
\hline & Thur PM & & & & & & & & & & & 28.5 & 60.4 & 9.2 & 19.5 \\
\hline \multirow[t]{4}{*}{ CAJS22 } & Wed AM & 11.6 & 24.5 & 0.42 & 0.08 & 0.38 & 27.7 & 58.7 & 1.00 & 0.20 & 0.92 & & & & \\
\hline & Wed PM & 14.6 & 31.0 & 0.52 & 0.10 & 0.47 & 30.1 & 63.8 & 1.06 & 0.21 & 0.97 & 14.9 & 31.6 & 2.8 & 6.0 \\
\hline & Thur AM & 10.7 & 22.7 & 0.32 & 0.06 & 0.29 & 38.2 & 80.9 & 1.12 & 0.22 & 1.03 & & & & \\
\hline & Thur PM & 5.3 & 11.3 & 0.20 & 0.04 & 0.19 & 25.2 & 53.3 & 0.97 & 0.19 & 0.89 & & & & \\
\hline \multirow[t]{4}{*}{ CAJS23 } & Wed AM & 47.3 & 100.2 & 2.67 & 0.52 & 2.44 & 68.6 & 145.4 & 3.87 & 0.76 & 3.57 & 13.9 & 29.5 & 2.5 & 5.3 \\
\hline & Wed PM & 11.2 & 23.7 & 0.59 & 0.12 & 0.54 & 79.4 & 168.2 & 4.21 & 0.83 & 3.85 & 22.5 & 47.7 & 5.9 & 12.5 \\
\hline & Thur AM & 0.0 & 0.0 & 0.00 & 0.00 & 0.00 & 94.3 & 199.8 & 5.00 & 0.98 & 4.58 & 22.8 & 48.3 & 6.0 & 12.8 \\
\hline & Thur PM & 0.0 & 0.0 & 0.00 & 0.00 & 0.00 & 119.7 & 253.7 & 5.13 & 1.01 & 4.70 & 16.1 & 34.2 & 3.2 & 6.9 \\
\hline \multirow[t]{4}{*}{ CAJW18 } & Wed AM & 47.8 & 101.2 & 1.50 & 0.30 & 1.46 & 85.9 & 182.1 & 2.71 & 0.53 & 2.64 & 12.9 & 27.3 & 2.3 & 4.8 \\
\hline & Wed PM & 41.3 & 87.5 & 1.22 & 0.24 & 1.18 & 84.0 & 177.9 & 2.48 & 0.49 & 2.42 & 13.0 & 27.6 & 2.3 & 4.9 \\
\hline & \begin{tabular}{|l} 
Thur AM \\
\end{tabular} & 44.3 & 93.9 & 1.17 & 0.23 & 1.13 & 156.0 & 330.4 & 4.11 & 0.81 & 3.99 & 14.9 & 31.6 & 2.9 & 6.1 \\
\hline & Thur PM & 42.7 & 90.4 & 1.15 & 0.23 & 1.12 & 109.1 & 231.1 & 2.94 & 0.58 & 2.86 & 12.0 & 25.5 & 2.0 & 4.3 \\
\hline \multirow[t]{4}{*}{ CAJW19 } & Wed AM & 87.7 & 185.7 & 2.69 & 0.53 & 2.61 & 247.5 & 524.3 & 7.59 & 1.49 & 7.38 & 32.1 & 68.1 & 11.9 & 25.3 \\
\hline & Wed PM & 113.8 & 241.0 & 3.57 & 0.70 & 3.46 & 228.5 & 484.2 & 7.17 & 1.41 & 6.98 & 27.1 & 57.4 & 8.6 & 18.2 \\
\hline & Thur AM & 96.0 & 203.3 & 3.01 & 0.59 & 2.92 & 178.5 & 378.2 & 5.60 & 1.10 & 5.46 & 24.3 & 51.4 & 7.0 & 14.8 \\
\hline & Thur PM & 82.4 & 174.6 & 2.59 & 0.51 & 2.51 & 224.7 & 476.0 & 7.05 & 1.39 & 6.85 & & & & \\
\hline \multirow[t]{4}{*}{ CAJW20 } & Wed AM & 57.6 & 122.0 & 1.82 & 0.36 & 1.60 & 60.4 & 128.1 & 1.91 & 0.38 & 1.70 & 22.4 & 47.4 & 6.0 & 12.7 \\
\hline & Wed PM & 70.6 & 149.6 & 1.97 & 0.39 & 1.74 & 78.7 & 166.7 & 2.20 & 0.43 & 1.96 & 21.7 & 46.0 & 5.7 & 12.0 \\
\hline & Thur AM & 68.1 & 144.2 & 1.93 & 0.38 & 1.70 & 40.8 & 86.5 & 1.16 & 0.23 & 1.06 & 25.3 & 53.5 & 7.5 & 16.0 \\
\hline & Thur PM & 60.3 & 127.8 & 1.81 & 0.36 & 1.59 & 47.4 & 100.4 & 1.42 & 0.28 & 1.28 & 21.6 & 45.7 & 5.6 & 11.9 \\
\hline
\end{tabular}




\begin{tabular}{|c|c|c|c|c|c|c|c|c|c|c|c|c|c|c|c|}
\hline \multirow{3}{*}{$\begin{array}{l}\text { Study Space } \\
\text { ID }\end{array}$} & \multirow[b]{3}{*}{ Period } & \multicolumn{14}{|c|}{ OUTDOOR AIRFLOW } \\
\hline & & \multicolumn{5}{|c|}{$\mathrm{CO}_{2}$ Ratio } & \multicolumn{5}{|c|}{ Uncertainty in $\mathrm{CO}_{2}$ ratio $\mathrm{OA}$} & \multicolumn{2}{|c|}{ Peak $\mathrm{CO}_{2}$} & \multicolumn{2}{|c|}{$\begin{array}{c}\text { Uncertainty in peak } \mathrm{CO}_{2} \\
\text { OA }\end{array}$} \\
\hline & & L/s•person & $\mathrm{cfm} /$ person & $\mathrm{L} / \mathrm{s} \cdot \mathrm{m}^{2}$ & $\mathrm{cfm} / \mathrm{ft}^{2}$ & $\mathrm{~h}^{-1}$ & L/s*person & $\mathrm{cfm} /$ person & $\mathrm{L} / \mathrm{s} \cdot \mathrm{m}^{2}$ & $\mathrm{cfm} / \mathrm{ft}^{2}$ & $\mathrm{~h}^{-1}$ & $\mathrm{~L} / \mathrm{s} \bullet$ person & cfm/person & $L / s \bullet$ person & $\mathrm{cfm} /$ person \\
\hline \multirow[t]{6}{*}{ CAJW24 } & Tues AM & 13.1 & 27.7 & 0.89 & 0.18 & 0.85 & 93.3 & 197.6 & 6.39 & 1.26 & 6.09 & 33.8 & 71.6 & 12.8 & 27.0 \\
\hline & Tues PM & 3.0 & 6.5 & 0.22 & 0.04 & 0.21 & 21.6 & 45.7 & 1.58 & 0.31 & 1.51 & 12.9 & 27.4 & 2.2 & 4.7 \\
\hline & Wed AM & 13.2 & 28.1 & 0.89 & 0.18 & 0.85 & 94.6 & 200.5 & 6.39 & 1.26 & 6.09 & 28.8 & 61.1 & 9.4 & 19.9 \\
\hline & Wed PM & 3.7 & 7.9 & 0.24 & 0.05 & 0.23 & 26.5 & 56.1 & 1.68 & 0.33 & 1.60 & 11.9 & 25.3 & 1.9 & 4.1 \\
\hline & Thur AM & 82.8 & 175.4 & 5.67 & 1.12 & 5.40 & 122.8 & 260.1 & 8.41 & 1.66 & 8.06 & 41.3 & 87.4 & 18.8 & 39.8 \\
\hline & Thur PM & 51.0 & 108.1 & 3.04 & 0.60 & 2.89 & 194.4 & 411.9 & 11.58 & 2.28 & 11.04 & 30.0 & 63.6 & 10.2 & 21.5 \\
\hline \multirow[t]{4}{*}{ CAJW25 } & Wed AM & 40.8 & 86.5 & 2.29 & 0.45 & 2.19 & 53.4 & 113.2 & 3.00 & 0.59 & 2.90 & 24.1 & 51.1 & 6.7 & 14.2 \\
\hline & Wed PM & 74.8 & 158.5 & 4.40 & 0.87 & 4.21 & 87.4 & 185.2 & 5.14 & 1.01 & 4.98 & 28.1 & 59.6 & 9.0 & 19.0 \\
\hline & Thur AM & 28.9 & 61.1 & 1.54 & 0.30 & 1.48 & 71.9 & 152.3 & 3.84 & 0.76 & 3.68 & 19.6 & 41.6 & 4.6 & 9.7 \\
\hline & \begin{tabular}{|l|} 
Thur PM \\
\end{tabular} & 64.6 & 136.8 & 4.33 & 0.85 & 4.14 & 75.5 & 159.9 & 5.06 & 1.00 & 4.89 & & & & \\
\hline \multirow[t]{4}{*}{ CAJW26 } & Wed AM & 78.5 & 166.3 & 3.51 & 0.69 & 3.36 & 134.1 & 284.0 & 6.00 & 1.18 & 5.77 & 26.3 & 55.8 & 7.9 & 16.8 \\
\hline & Wed PM & 51.8 & 109.7 & 2.96 & 0.58 & 2.83 & 117.3 & 248.4 & 6.71 & 1.32 & 6.44 & 29.2 & 61.9 & 9.7 & 20.5 \\
\hline & Thur AM & 82.9 & 175.6 & 5.52 & 1.09 & 5.28 & 104.6 & 221.6 & 6.96 & 1.37 & 6.73 & 23.1 & 49.0 & 6.2 & 13.1 \\
\hline & Thur PM & 92.9 & 196.8 & 5.80 & 1.14 & 5.55 & 82.3 & 174.5 & 5.14 & 1.01 & 5.01 & 33.6 & 71.1 & 12.6 & 26.6 \\
\hline \multirow[t]{4}{*}{ COAS02 } & Wed AM & 0.0 & 0.0 & 0.00 & 0.00 & 0.00 & 54.6 & 115.6 & 1.92 & 0.38 & 1.38 & 25.4 & 53.8 & 7.6 & 16.1 \\
\hline & Wed PM & 0.0 & 0.0 & 0.00 & 0.00 & 0.00 & 41.9 & 88.8 & 1.42 & 0.28 & 1.02 & 18.9 & 40.1 & 4.4 & 9.4 \\
\hline & Thur AM & 15.3 & 32.4 & 0.47 & 0.09 & 0.34 & 43.9 & 93.0 & 1.35 & 0.26 & 0.97 & 20.0 & 42.4 & 4.9 & 10.3 \\
\hline & Thur PM & 17.5 & 37.1 & 0.51 & 0.10 & 0.37 & 50.3 & 106.5 & 1.47 & 0.29 & 1.06 & 18.7 & 39.6 & 4.3 & 9.2 \\
\hline \multirow[t]{4}{*}{ COAS04 } & Wed AM & 72.0 & 152.6 & 2.17 & 0.43 & 1.56 & 121.4 & 257.1 & 3.65 & 0.72 & 2.64 & 21.2 & 44.9 & 5.4 & 11.5 \\
\hline & Wed PM & 52.4 & 111.0 & 1.61 & 0.32 & 1.16 & 96.4 & 204.1 & 2.96 & 0.58 & 2.14 & 17.2 & 36.4 & 3.7 & 7.8 \\
\hline & Thur AM & 24.5 & 51.8 & 0.65 & 0.13 & 0.47 & 87.1 & 184.6 & 2.33 & 0.46 & 1.68 & 18.8 & 39.8 & 4.4 & 9.2 \\
\hline & Thur PM & 0.0 & 0.0 & 0.00 & 0.00 & 0.00 & 95.0 & 201.2 & 2.97 & 0.58 & 2.14 & 16.9 & 35.9 & 3.6 & 7.6 \\
\hline \multirow[t]{4}{*}{ COAS06 } & Wed AM & 24.4 & 51.7 & 0.61 & 0.12 & 0.58 & 32.8 & 69.6 & 0.82 & 0.16 & 0.78 & 12.8 & 27.2 & 2.2 & 4.7 \\
\hline & Wed PM & 41.2 & 87.2 & 1.17 & 0.23 & 1.12 & 24.3 & 51.5 & 0.69 & 0.14 & 0.69 & 10.0 & 21.1 & 1.5 & 3.1 \\
\hline & \begin{tabular}{|l} 
Thur AM \\
\end{tabular} & 8.9 & 19.0 & 0.31 & 0.06 & 0.29 & 42.3 & 89.6 & 1.45 & 0.29 & 1.38 & 14.1 & 29.9 & 2.6 & 5.6 \\
\hline & \begin{tabular}{|l|} 
Thur PM \\
\end{tabular} & 6.8 & 14.4 & 0.20 & 0.04 & 0.19 & 26.7 & 56.6 & 0.80 & 0.16 & 0.76 & 11.4 & 24.1 & 1.8 & 3.9 \\
\hline \multirow[t]{4}{*}{ FLDW07 } & Wed AM & 0.0 & 0.0 & 0.00 & 0.00 & 0.00 & 53.9 & 114.1 & 1.16 & 0.23 & 0.95 & 14.4 & 30.6 & 2.7 & 5.7 \\
\hline & Wed PM & 0.0 & 0.0 & 0.00 & 0.00 & 0.00 & 48.1 & 101.8 & 0.96 & 0.19 & 0.79 & 12.7 & 26.8 & 2.1 & 4.5 \\
\hline & Thur AM & 6.5 & 13.8 & 0.13 & 0.02 & 0.10 & 46.0 & 97.6 & 0.90 & 0.18 & 0.74 & 12.0 & 25.5 & 2.0 & 4.2 \\
\hline & Thur PM & 5.3 & 11.2 & 0.11 & 0.02 & 0.09 & 37.6 & 79.6 & 0.79 & 0.16 & 0.65 & 11.8 & 25.0 & 1.9 & 4.0 \\
\hline \multirow[t]{4}{*}{ FLDW08 } & Wed AM & 34.0 & 72.0 & 1.16 & 0.23 & 0.98 & 35.9 & 76.1 & 1.22 & 0.24 & 1.05 & 15.0 & 31.7 & 2.8 & 6.0 \\
\hline & Wed PM & 28.6 & 60.7 & 1.00 & 0.20 & 0.84 & 34.8 & 73.7 & 1.21 & 0.24 & 1.03 & 14.3 & 30.4 & 2.6 & 5.6 \\
\hline & Thur AM & 13.9 & 29.5 & 0.66 & 0.13 & 0.56 & 99.5 & 210.8 & 4.72 & 0.93 & 3.98 & 21.9 & 46.3 & 5.6 & 11.8 \\
\hline & Thur PM & 133.2 & 282.3 & 4.64 & 0.91 & 3.91 & 333.9 & 707.3 & 11.63 & 2.29 & 9.83 & 23.2 & 49.1 & 6.2 & 13.2 \\
\hline \multirow[t]{4}{*}{ FLDW10 } & Wed AM & 11.9 & 25.1 & 0.59 & 0.12 & 0.58 & 34.6 & 73.4 & 1.74 & 0.34 & 1.71 & 21.4 & 45.3 & 5.4 & 11.4 \\
\hline & Wed PM & 7.8 & 16.4 & 0.36 & 0.07 & 0.35 & 37.0 & 78.3 & 1.71 & 0.34 & 1.68 & 20.9 & 44.3 & 5.2 & 10.9 \\
\hline & Thur AM & 7.7 & 16.4 & 0.47 & 0.09 & 0.46 & 22.3 & 47.3 & 1.35 & 0.27 & 1.33 & 16.6 & 35.2 & 3.4 & 7.2 \\
\hline & Thur PM & 3.8 & 8.1 & 0.17 & 0.03 & 0.17 & 27.0 & 57.2 & 1.20 & 0.24 & 1.18 & & & & \\
\hline \multirow[t]{4}{*}{ FLGS01 } & Thur AM & 22.4 & 47.6 & 0.80 & 0.16 & 0.79 & 30.0 & 63.7 & 1.07 & 0.21 & 1.07 & 15.9 & 33.6 & 3.2 & 6.8 \\
\hline & Thur PM & 46.3 & 98.1 & 1.65 & 0.33 & 1.63 & 37.2 & 78.7 & 1.33 & 0.26 & 1.34 & 14.4 & 30.5 & 2.7 & 5.8 \\
\hline & Fri AM & 21.9 & 46.3 & 0.69 & 0.13 & 0.67 & 35.4 & 75.1 & 1.11 & 0.22 & 1.10 & 15.6 & 33.0 & 3.1 & 6.6 \\
\hline & Fri PM & 20.0 & 42.4 & 0.63 & 0.12 & 0.62 & 41.3 & 87.6 & 1.30 & 0.26 & 1.28 & 17.8 & 37.8 & 4.0 & 8.4 \\
\hline
\end{tabular}




\begin{tabular}{|c|c|c|c|c|c|c|c|c|c|c|c|c|c|c|c|}
\hline \multirow{3}{*}{$\begin{array}{c}\text { Study Space } \\
\text { ID }\end{array}$} & \multirow[b]{3}{*}{ Period } & \multicolumn{14}{|c|}{ OUTDOOR AIRFLOW } \\
\hline & & \multicolumn{5}{|c|}{$\mathrm{CO}_{2}$ Ratio } & \multicolumn{5}{|c|}{ Uncertainty in $\mathrm{CO}_{2}$ ratio $\mathrm{OA}$} & \multicolumn{2}{|c|}{ Peak $\mathrm{CO}_{2}$} & \multicolumn{2}{|c|}{$\begin{array}{c}\text { Uncertainty in peak } \mathrm{CO}_{2} \\
\mathrm{OA}\end{array}$} \\
\hline & & $\mathrm{L} / \mathrm{s} \bullet$ person & $\mathrm{cfm} /$ person & $\mathrm{L} / \mathrm{s} \cdot \mathrm{m}^{2}$ & $\mathrm{cfm} / \mathrm{ft}^{2}$ & $\mathrm{~h}^{-1}$ & $\mathrm{~L} / \mathrm{s} \cdot$ person & cfm/person & $\mathrm{L} / \mathrm{s} \cdot \mathrm{m}^{2}$ & $\mathrm{cfm} / \mathrm{ft}^{2}$ & $\mathrm{~h}^{-1}$ & $\mathrm{~L} / \mathrm{s} \bullet$ person & cfm/person & $\mathrm{L} / \mathrm{s} \cdot$ person & $\mathrm{cfm} /$ person \\
\hline \multirow{3}{*}{ FLGS04 } & Wed PM & 6.1 & 13.0 & 0.32 & 0.06 & 0.31 & 19.3 & 40.9 & 1.00 & 0.20 & 0.99 & 8.4 & 17.8 & 1.2 & 2.4 \\
\hline & Thur AM & 16.6 & 35.1 & 0.81 & 0.16 & 0.80 & 23.1 & 48.9 & 1.13 & 0.22 & 1.12 & 9.6 & 20.3 & 1.4 & 3.0 \\
\hline & Thur PM & 6.6 & 13.9 & 0.32 & 0.06 & 0.32 & 21.2 & 45.0 & 1.04 & 0.20 & 1.03 & 8.8 & 18.6 & 1.2 & 2.6 \\
\hline \multirow[t]{3}{*}{ FLGS11 } & Wed AM & 3.1 & 6.7 & 0.09 & 0.02 & 0.10 & 13.7 & 29.0 & 0.37 & 0.07 & 0.42 & & & & \\
\hline & Thur AM & 7.1 & 14.9 & 0.18 & 0.04 & 0.20 & 12.7 & 26.9 & 0.32 & 0.06 & 0.37 & & & & \\
\hline & Thur PM & 4.9 & 10.4 & 0.12 & 0.02 & 0.14 & 12.4 & 26.2 & 0.31 & 0.06 & 0.35 & 6.8 & 14.4 & 0.8 & 1.8 \\
\hline \multirow[t]{4}{*}{ FLGS12 } & Wed AM & & & & & & & & & & & 12.5 & 26.5 & 2.1 & 4.4 \\
\hline & Wed PM & 25.2 & 53.3 & 1.09 & 0.21 & 1.16 & 36.5 & 77.3 & 1.58 & 0.31 & 1.70 & 8.9 & 18.9 & 1.2 & 2.6 \\
\hline & Thur AM & 16.2 & 34.3 & 0.69 & 0.13 & 0.73 & 46.2 & 97.9 & 1.95 & 0.38 & 2.10 & 11.2 & 23.7 & 1.8 & 3.7 \\
\hline & Thur PM & 22.7 & 48.2 & 1.23 & 0.24 & 1.32 & 24.1 & 51.0 & 1.30 & 0.26 & 1.41 & 9.1 & 19.4 & 1.3 & 2.7 \\
\hline \multirow[t]{3}{*}{ GADS01 } & Wed AM & 20.7 & 43.9 & 0.61 & 0.12 & 0.57 & 60.6 & 128.4 & 1.77 & 0.35 & 1.68 & 22.4 & 47.5 & 5.9 & 12.4 \\
\hline & Wed PM & 40.4 & 85.6 & 0.95 & 0.19 & 0.90 & 76.7 & 162.4 & 1.80 & 0.35 & 1.71 & 18.2 & 38.5 & 4.0 & 8.5 \\
\hline & Thur AM & 32.9 & 69.6 & 0.81 & 0.16 & 0.77 & 61.7 & 130.8 & 1.53 & 0.30 & 1.45 & 27.5 & 58.3 & 8.6 & 18.2 \\
\hline \multirow[t]{4}{*}{ GADS02 } & Wed AM & 25.9 & 55.0 & 0.45 & 0.09 & 0.43 & 43.7 & 92.7 & 0.77 & 0.15 & 0.73 & 14.2 & 30.0 & 2.6 & 5.5 \\
\hline & Wed PM & 29.0 & 61.3 & 0.60 & 0.12 & 0.57 & 29.6 & 62.7 & 0.61 & 0.12 & 0.59 & 14.4 & 30.5 & 2.7 & 5.6 \\
\hline & Thur AM & 17.3 & 36.7 & 0.32 & 0.06 & 0.30 & 49.5 & 104.8 & 0.91 & 0.18 & 0.86 & 17.6 & 37.3 & 3.8 & 8.0 \\
\hline & Thur PM & 36.4 & 77.2 & 0.69 & 0.14 & 0.65 & 39.6 & 83.8 & 0.75 & 0.15 & 0.72 & & & & \\
\hline \multirow[t]{4}{*}{ GADS03 } & Wed AM & 13.3 & 28.3 & 0.53 & 0.10 & 0.53 & 18.3 & 38.8 & 0.72 & 0.14 & 0.73 & 7.7 & 16.4 & 1.0 & 2.1 \\
\hline & Wed PM & 0.0 & 0.0 & 0.00 & 0.00 & 0.00 & 11.8 & 25.1 & 0.56 & 0.11 & 0.56 & 6.5 & 13.7 & 0.8 & 1.7 \\
\hline & Thur AM & 6.2 & 13.0 & 0.27 & 0.05 & 0.27 & 17.5 & 37.0 & 0.76 & 0.15 & 0.76 & 9.3 & 19.6 & 1.3 & 2.8 \\
\hline & Thur PM & 0.0 & 0.0 & 0.00 & 0.00 & 0.00 & 14.1 & 29.9 & 0.57 & 0.11 & 0.57 & & & & \\
\hline \multirow[t]{4}{*}{ ILBS01 } & Wed AM & 31.9 & 67.7 & 1.09 & 0.21 & 1.08 & 40.0 & 84.8 & 1.36 & 0.27 & 1.37 & 15.8 & 33.5 & 3.1 & 6.6 \\
\hline & Wed PM & 23.6 & 50.0 & 0.76 & 0.15 & 0.75 & 36.8 & 78.0 & 1.18 & 0.23 & 1.18 & 12.0 & 25.5 & 2.0 & 4.2 \\
\hline & Thur AM & 16.2 & 34.4 & 0.46 & 0.09 & 0.46 & 60.1 & 127.4 & 1.71 & 0.34 & 1.71 & 14.4 & 30.5 & 2.7 & 5.6 \\
\hline & Thur PM & 14.9 & 31.6 & 0.39 & 0.08 & 0.38 & 34.3 & 72.6 & 0.88 & 0.17 & 0.88 & 11.3 & 24.0 & 1.8 & 3.8 \\
\hline \multirow[t]{4}{*}{ ILBS02 } & Wed AM & 0.0 & 0.0 & 0.00 & 0.00 & 0.00 & 141.1 & 298.9 & 4.73 & 0.93 & 5.33 & 26.8 & 56.8 & 8.2 & 17.3 \\
\hline & Wed PM & 19.1 & 40.5 & 0.56 & 0.11 & 0.64 & 135.6 & 287.4 & 3.99 & 0.79 & 4.51 & 25.3 & 53.5 & 7.3 & 15.5 \\
\hline & Thur AM & 39.9 & 84.4 & 0.89 & 0.18 & 1.00 & 284.1 & 601.9 & 6.35 & 1.25 & 7.16 & 29.2 & 61.9 & 9.7 & 20.5 \\
\hline & Thur PM & 0.0 & 0.0 & 0.00 & 0.00 & 0.00 & 246.0 & 521.2 & 5.75 & 1.13 & 6.48 & & & & \\
\hline \multirow[t]{3}{*}{ ILBS03 } & Wed AM & 128.8 & 272.9 & 3.42 & 0.67 & 3.51 & 192.9 & 408.6 & 5.12 & 1.01 & 5.30 & 23.1 & 49.0 & 6.2 & 13.1 \\
\hline & Wed PM & 91.3 & 193.4 & 3.06 & 0.60 & 3.14 & 134.9 & 285.7 & 4.52 & 0.89 & 4.68 & 18.0 & 38.1 & 3.9 & 8.3 \\
\hline & Thur AM & 156.0 & 330.6 & 3.45 & 0.68 & 3.55 & 233.7 & 495.0 & 5.17 & 1.02 & 5.35 & 42.3 & 89.5 & 19.7 & 41.7 \\
\hline \multirow{3}{*}{ LAGW04 } & Wed PM & 10.8 & 22.8 & 0.28 & 0.06 & 0.29 & 78.9 & 167.2 & 2.08 & 0.41 & 2.14 & 10.2 & 21.5 & 1.5 & 3.2 \\
\hline & Thur AM & 49.0 & 103.9 & 1.16 & 0.23 & 1.20 & 64.7 & 137.0 & 1.53 & 0.30 & 1.59 & 14.6 & 31.0 & 2.8 & 5.9 \\
\hline & Thur PM & 32.9 & 69.6 & 0.77 & 0.15 & 0.79 & 70.4 & 149.1 & 1.64 & 0.32 & 1.70 & & & & \\
\hline
\end{tabular}




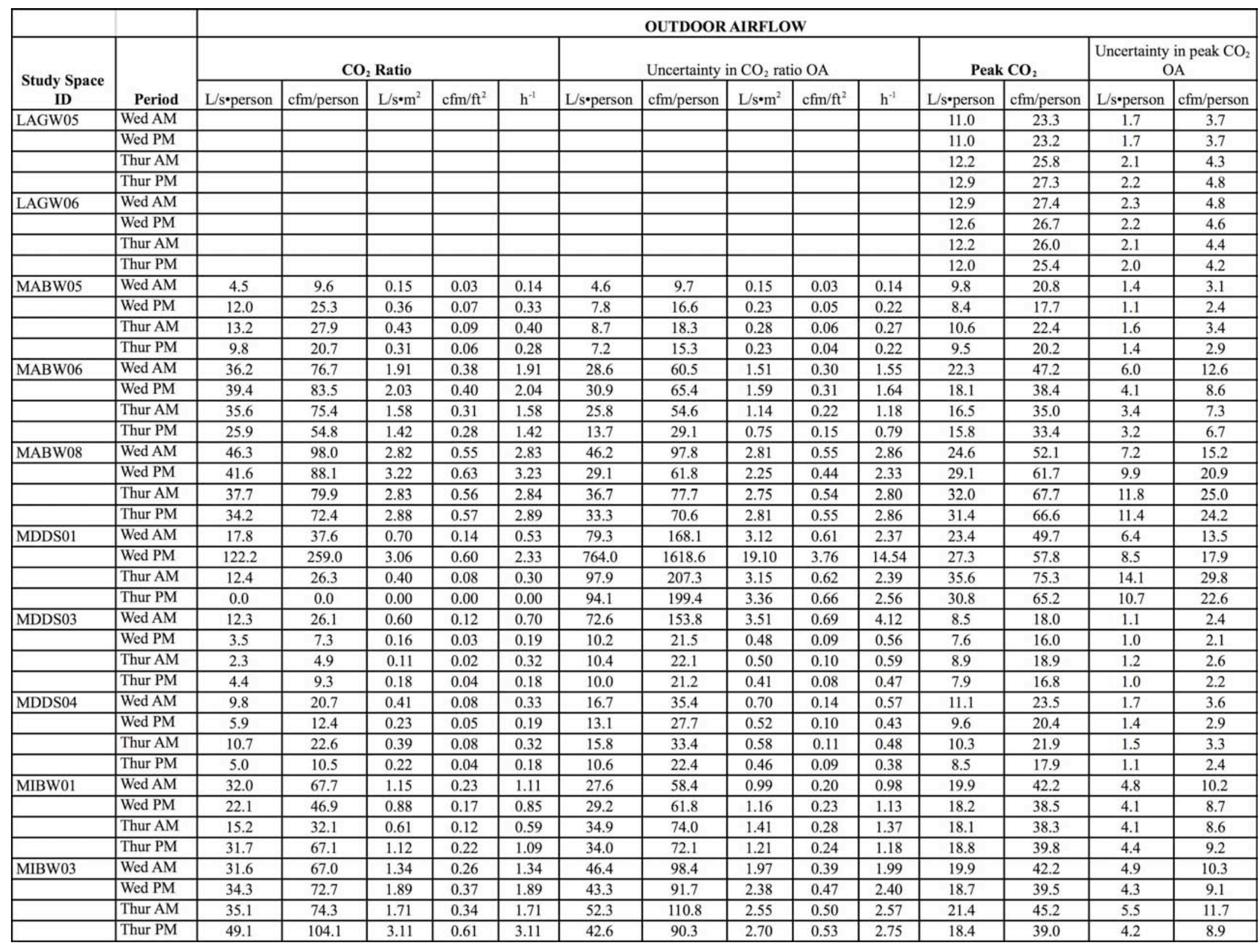




\begin{tabular}{|c|c|c|c|c|c|c|c|c|c|c|c|c|c|c|c|}
\hline \multirow{3}{*}{$\begin{array}{l}\text { Study Space } \\
\text { ID }\end{array}$} & \multirow[b]{3}{*}{ Period } & \multicolumn{14}{|c|}{ OUTDOOR AIRFLOW } \\
\hline & & \multicolumn{5}{|c|}{$\mathrm{CO}_{2}$ Ratio } & \multicolumn{5}{|c|}{ Uncertainty in $\mathrm{CO}_{2}$ ratio $\mathrm{OA}$} & \multicolumn{2}{|c|}{ Peak $\mathrm{CO}_{2}$} & \multicolumn{2}{|c|}{$\begin{array}{c}\text { Uncertainty in peak } \mathrm{CO}_{2} \\
\mathrm{OA}\end{array}$} \\
\hline & & L/s•person & $\mathrm{cfm} /$ person & $\mathrm{L} / \mathrm{s} \cdot \mathrm{m}^{2}$ & $\mathrm{cfm} / \mathrm{ft}^{2}$ & $\mathrm{~h}^{-1}$ & L/s•person & $\mathrm{cfm} /$ person & $\mathrm{L} / \mathrm{s} \cdot \mathrm{m}^{2}$ & $\mathrm{cfm} / \mathrm{ft}^{2}$ & $\mathrm{~h}^{-1}$ & L/s•person & cfm/person & $\mathrm{L} / \mathrm{s} \bullet$ person & $\mathrm{cfm} /$ person \\
\hline \multirow{4}{*}{\begin{tabular}{|l|} 
MIBW04 \\
\end{tabular}} & Wed AM & 22.8 & 48.3 & 1.02 & 0.20 & 1.02 & 19.0 & 40.3 & 0.85 & 0.17 & 0.87 & 21.9 & 46.4 & 5.8 & 12.2 \\
\hline & Wed PM & 24.4 & 51.7 & 1.02 & 0.20 & 1.02 & 24.0 & 50.8 & 1.00 & 0.20 & 1.01 & 21.8 & 46.2 & 5.7 & 12.1 \\
\hline & Thur AM & 17.8 & 37.8 & 0.71 & 0.14 & 0.71 & 24.5 & 51.9 & 0.97 & 0.19 & 0.98 & 20.3 & 43.0 & 5.0 & 10.6 \\
\hline & Thur PM & 37.8 & 80.0 & 1.11 & 0.22 & 1.11 & 39.1 & 82.7 & 1.15 & 0.23 & 1.17 & 20.6 & 43.7 & 5.2 & 10.9 \\
\hline \multirow[t]{4}{*}{ MNBW01 } & Wed AM & 73.4 & 155.5 & 1.41 & 0.28 & 1.38 & 58.9 & 124.9 & 1.13 & 0.22 & 1.14 & 17.2 & 36.4 & 3.7 & 7.9 \\
\hline & Wed PM & 69.7 & 147.7 & 1.29 & 0.25 & 1.27 & 71.6 & 151.7 & 1.32 & 0.26 & 1.32 & 15.4 & 32.6 & 3.1 & 6.5 \\
\hline & Thur AM & 52.9 & 112.0 & 0.94 & 0.19 & 0.93 & 79.2 & 167.8 & 1.41 & 0.28 & 1.40 & 18.3 & 38.8 & 4.2 & 8.8 \\
\hline & Thur PM & 87.8 & 185.9 & 1.33 & 0.26 & 1.31 & 90.9 & 192.5 & 1.38 & 0.27 & 1.38 & 18.0 & 38.1 & 4.0 & 8.5 \\
\hline \multirow[t]{4}{*}{ MNBW02 } & Wed AM & 58.1 & 123.2 & 1.20 & 0.24 & 1.28 & 73.0 & 154.6 & 1.51 & 0.30 & 1.63 & 29.4 & 62.4 & 10.1 & 21.4 \\
\hline & Wed PM & 58.7 & 124.5 & 1.54 & 0.30 & 1.64 & 95.8 & 203.0 & 2.50 & 0.49 & 2.70 & 29.8 & 63.2 & 10.3 & 21.9 \\
\hline & Thur AM & 38.8 & 82.3 & 1.07 & 0.21 & 1.14 & 61.1 & 129.4 & 1.68 & 0.33 & 1.81 & 28.3 & 60.0 & 9.4 & 19.8 \\
\hline & Thur PM & 63.5 & 134.5 & 1.53 & 0.30 & 1.64 & 114.5 & 242.5 & 2.75 & 0.54 & 2.96 & 41.1 & 87.1 & 19.2 & 40.7 \\
\hline \multirow[t]{4}{*}{ MNBW04 } & Wed AM & 107.6 & 228.0 & 1.93 & 0.38 & 2.12 & 65.1 & 137.8 & 1.17 & 0.23 & 1.33 & 20.2 & 42.8 & 5.2 & 11.1 \\
\hline & Wed PM & 300.5 & 636.7 & 2.79 & 0.55 & 3.06 & 229.1 & 485.3 & 2.12 & 0.42 & 2.39 & 44.7 & 94.8 & 24.0 & 50.9 \\
\hline & Thur AM & 106.8 & 226.2 & 2.29 & 0.45 & 2.51 & 97.0 & 205.5 & 2.08 & 0.41 & 2.32 & 30.5 & 64.7 & 11.4 & 24.2 \\
\hline & Thur PM & 103.1 & 218.5 & 2.27 & 0.45 & 2.49 & 76.3 & 161.7 & 1.68 & 0.33 & 1.89 & 36.2 & 76.6 & 15.8 & 33.6 \\
\hline \multirow[t]{4}{*}{ MOCS01 } & Wed AM & 14.9 & 31.7 & 0.52 & 0.10 & 0.57 & 21.7 & 46.0 & 0.76 & 0.15 & 0.84 & 19.4 & 41.1 & 4.6 & 9.8 \\
\hline & Wed PM & 24.1 & 51.1 & 0.84 & 0.17 & 0.93 & 24.0 & 50.8 & 0.84 & 0.17 & 0.93 & 21.9 & 46.3 & 5.8 & 12.2 \\
\hline & Thur AM & 14.8 & 31.3 & 0.59 & 0.12 & 0.65 & 26.8 & 56.7 & 1.07 & 0.21 & 1.18 & 21.8 & 46.1 & 5.7 & 12.1 \\
\hline & \begin{tabular}{|l|} 
Thur PM \\
\end{tabular} & 18.2 & 38.6 & 0.61 & 0.12 & 0.67 & 26.5 & 56.1 & 0.89 & 0.18 & 0.99 & & & & \\
\hline \multirow[t]{4}{*}{ MOCS05 } & Wed AM & 32.3 & 68.4 & 1.03 & 0.20 & 0.92 & 48.5 & 102.7 & 1.55 & 0.30 & 1.39 & 29.9 & 63.3 & 10.4 & 22.0 \\
\hline & Wed PM & 25.9 & 54.9 & 0.79 & 0.16 & 0.70 & 41.2 & 87.2 & 1.25 & 0.25 & 1.12 & 27.2 & 57.7 & 8.7 & 18.4 \\
\hline & Thur AM & 24.1 & 51.0 & 0.70 & 0.14 & 0.62 & 35.4 & 74.9 & 1.02 & 0.20 & 0.92 & 22.3 & 47.3 & 6.0 & 12.7 \\
\hline & Thur PM & 17.6 & 37.3 & 0.58 & 0.11 & 0.51 & 21.5 & 45.4 & 0.70 & 0.14 & 0.63 & 18.7 & 39.6 & 4.3 & 9.1 \\
\hline \multirow[t]{4}{*}{\begin{tabular}{|l|} 
NCDW02 \\
\end{tabular}} & Wed AM & 88.4 & 187.2 & 2.26 & 0.45 & 2.94 & 97.7 & 206.9 & 2.50 & 0.49 & 3.29 & 24.5 & 51.9 & 6.9 & 14.7 \\
\hline & Wed PM & 76.7 & 162.6 & 2.31 & 0.45 & 3.00 & 83.5 & 176.9 & 2.52 & 0.50 & 3.31 & 31.3 & 66.3 & 11.0 & 23.3 \\
\hline & Thur AM & 32.6 & 69.0 & 1.21 & 0.24 & 1.57 & 55.1 & 116.8 & 2.05 & 0.40 & 2.68 & 25.8 & 54.6 & 7.6 & 16.1 \\
\hline & Thur PM & 51.9 & 110.0 & 1.98 & 0.39 & 2.57 & 64.6 & 136.9 & 2.47 & 0.49 & 3.23 & 30.5 & 64.7 & 10.5 & 22.2 \\
\hline \multirow[t]{4}{*}{\begin{tabular}{|l|} 
NCDW03 \\
\end{tabular}} & Wed AM & & & & & & & & & & & 15.8 & 33.6 & 3.1 & 6.6 \\
\hline & Wed PM & & & & & & & & & & & 13.0 & 27.6 & 2.2 & 4.8 \\
\hline & Thur AM & & & & & & & & & & & 11.9 & 25.2 & 1.9 & 4.1 \\
\hline & Thur PM & & & & & & & & & & & 14.5 & 30.6 & 2.7 & 5.7 \\
\hline \multirow[t]{4}{*}{\begin{tabular}{|l|} 
NCDW06 \\
\end{tabular}} & Wed AM & 50.6 & 107.2 & 2.81 & 0.55 & 2.55 & 37.3 & 78.9 & 2.07 & 0.41 & 1.93 & 18.2 & 38.5 & 4.0 & 8.5 \\
\hline & Wed PM & 42.3 & 89.6 & 2.76 & 0.54 & 2.51 & 54.7 & 115.9 & 3.57 & 0.70 & 3.28 & 17.5 & 37.1 & 3.7 & 7.9 \\
\hline & Thur AM & 35.0 & 74.2 & 2.57 & 0.51 & 2.33 & 31.7 & 67.2 & 2.32 & 0.46 & 2.15 & 22.8 & 48.3 & 6.0 & 12.8 \\
\hline & Thur PM & 30.2 & 64.0 & 1.91 & 0.38 & 1.74 & 30.5 & 64.5 & 1.93 & 0.38 & 1.78 & 17.4 & 37.0 & 3.7 & 7.9 \\
\hline \multirow[t]{4}{*}{\begin{tabular}{|l|} 
NECW01 \\
\end{tabular}} & Wed AM & 27.6 & 58.6 & 1.39 & 0.27 & 1.05 & 22.4 & 47.5 & 1.13 & 0.22 & 0.87 & 19.2 & 40.7 & 4.5 & 9.6 \\
\hline & Wed PM & 36.4 & 77.1 & 1.79 & 0.35 & 1.35 & 36.7 & 77.8 & 1.80 & 0.36 & 1.38 & 22.1 & 46.7 & 5.8 & 12.4 \\
\hline & Thur AM & 28.6 & 60.6 & 1.52 & 0.30 & 1.15 & 26.8 & 56.8 & 1.42 & 0.28 & 1.09 & 21.5 & 45.5 & 5.6 & 11.8 \\
\hline & Thur PM & & & 1.98 & 0.39 & 1.49 & & & 2.09 & 0.41 & 1.60 & 25.0 & 52.9 & 7.4 & 15.6 \\
\hline
\end{tabular}




\begin{tabular}{|c|c|c|c|c|c|c|c|c|c|c|c|c|c|c|c|}
\hline \multirow{3}{*}{$\begin{array}{l}\text { Study Space } \\
\text { ID }\end{array}$} & \multirow[b]{3}{*}{ Period } & \multicolumn{14}{|c|}{ OUTDOOR AIRFLOW } \\
\hline & & \multicolumn{5}{|c|}{$\mathrm{CO}_{2}$ Ratio } & \multicolumn{5}{|c|}{ Uncertainty in $\mathrm{CO}_{2}$ ratio $\mathrm{OA}$} & \multicolumn{2}{|c|}{ Peak $\mathrm{CO}_{2}$} & \multicolumn{2}{|c|}{$\begin{array}{c}\text { Uncertainty in peak } \mathrm{CO}_{2} \\
\mathrm{OA}\end{array}$} \\
\hline & & $\mathrm{L} / \mathrm{s} \bullet$ person & $\mathrm{cfm} /$ person & $\mathrm{L} / \mathrm{s} \cdot \mathrm{m}^{2}$ & $\mathrm{cfm} / \mathrm{ft}^{2}$ & $\mathrm{~h}^{-1}$ & L/s•person & $\mathrm{cfm} /$ person & $\mathrm{L} / \mathrm{s} \cdot \mathrm{m}^{2}$ & $\mathrm{cfm} / \mathrm{ft}^{2}$ & $\mathrm{~h}^{-1}$ & $\mathrm{~L} / \mathrm{s}$ •person & cfm/person & $\mathrm{L} / \mathrm{s} \bullet$ person & cfm/person \\
\hline \multirow{4}{*}{ NECW02 } & Wed AM & 201.1 & 426.0 & 5.74 & 1.13 & 4.34 & 497.1 & 1053.2 & 14.19 & 2.79 & 10.76 & 70.2 & 148.6 & 55.2 & 116.9 \\
\hline & Wed PM & 128.5 & 272.2 & 4.22 & 0.83 & 3.19 & 219.5 & 465.0 & 7.22 & 1.42 & 5.48 & 74.0 & 156.8 & 61.4 & 130.0 \\
\hline & Thur AM & 163.1 & 345.5 & 5.78 & 1.14 & 4.37 & 403.2 & 854.2 & 14.30 & 2.81 & 10.84 & 83.1 & 176.0 & 77.2 & 163.5 \\
\hline & Thur PM & 338.6 & 717.4 & 6.45 & 1.27 & 4.87 & 768.8 & 1628.9 & 14.63 & 2.88 & 11.10 & 42.2 & 89.3 & 20.2 & 42.8 \\
\hline \multirow[t]{3}{*}{ NECW03 } & Wed AM & 31.8 & 67.4 & 2.08 & 0.41 & 2.09 & 41.2 & 87.3 & 2.70 & 0.53 & 2.73 & 24.2 & 51.3 & 7.0 & 14.8 \\
\hline & Thur AM & 29.1 & 61.8 & 1.93 & 0.38 & 1.94 & 42.9 & 90.9 & 2.84 & 0.56 & 2.87 & 27.1 & 57.4 & 8.6 & 18.2 \\
\hline & Thur PM & 59.2 & 125.5 & 3.88 & 0.76 & 3.89 & 55.2 & 117.0 & 3.62 & 0.71 & 3.69 & & & & \\
\hline \multirow[t]{4}{*}{ NMES01 } & Wed AM & 95.0 & 201.2 & 1.98 & 0.39 & 1.98 & 79.6 & 168.7 & 1.66 & 0.33 & 1.70 & 20.6 & 43.6 & 5.0 & 10.6 \\
\hline & Wed PM & 66.0 & 139.9 & 1.59 & 0.31 & 1.59 & 63.0 & 133.4 & 1.51 & 0.30 & 1.54 & 18.4 & 39.0 & 4.1 & 8.7 \\
\hline & Thur AM & 86.6 & 183.4 & 1.62 & 0.32 & 1.62 & 69.0 & 146.1 & 1.29 & 0.25 & 1.32 & 22.2 & 47.1 & 5.8 & 12.2 \\
\hline & Thur PM & 47.5 & 100.6 & 1.27 & 0.25 & 1.27 & 56.7 & 120.2 & 1.52 & 0.30 & 1.54 & 17.5 & 37.1 & 3.7 & 7.9 \\
\hline \multirow[t]{3}{*}{ NMES02 } & Wed AM & 66.2 & 140.2 & 2.65 & 0.52 & 2.47 & 105.0 & 222.5 & 4.21 & 0.83 & 3.95 & 31.3 & 66.3 & 11.0 & 23.3 \\
\hline & Wed PM & 158.9 & 336.7 & 5.69 & 1.12 & 5.31 & 106.6 & 225.9 & 3.82 & 0.75 & 3.68 & 24.0 & 50.8 & 6.6 & 14.1 \\
\hline & Thur AM & 158.7 & 336.3 & 5.82 & 1.15 & 5.43 & 259.7 & 550.3 & 9.52 & 1.87 & 8.93 & 35.2 & 74.6 & 13.8 & 29.2 \\
\hline \multirow[t]{4}{*}{ NMES03 } & Wed AM & 12.6 & 26.8 & 0.77 & 0.15 & 0.72 & 15.7 & 33.2 & 0.96 & 0.19 & 0.90 & 12.9 & 27.4 & 2.2 & 4.7 \\
\hline & Wed PM & 33.0 & 70.0 & 1.29 & 0.25 & 1.20 & 32.4 & 68.6 & 1.26 & 0.25 & 1.20 & 12.1 & 25.7 & 2.0 & 4.2 \\
\hline & Thur AM & 21.2 & 45.0 & 0.96 & 0.19 & 0.89 & 23.2 & 49.0 & 1.04 & 0.21 & 0.99 & 11.0 & 23.4 & 1.7 & 3.6 \\
\hline & Thur PM & 25.2 & 53.3 & 1.05 & 0.21 & 0.98 & 23.6 & 50.0 & 0.99 & 0.19 & 0.93 & & & & \\
\hline \multirow[t]{4}{*}{ NVAW01 } & Wed AM & 138.1 & 292.5 & 5.74 & 1.13 & 6.03 & 217.7 & 461.3 & 9.06 & 1.78 & 9.56 & 36.0 & 76.2 & 14.8 & 31.4 \\
\hline & Wed PM & 136.6 & 289.5 & 5.80 & 1.14 & 6.09 & 216.1 & 457.8 & 9.17 & 1.80 & 9.68 & 34.7 & 73.5 & 13.8 & 29.3 \\
\hline & Thur AM & 110.1 & 233.3 & 4.67 & 0.92 & 4.90 & 211.3 & 447.6 & 8.97 & 1.77 & 9.45 & 34.3 & 72.7 & 13.5 & 28.7 \\
\hline & Thur PM & 91.5 & 193.9 & 3.42 & 0.67 & 3.59 & 145.6 & 308.5 & 5.44 & 1.07 & 5.74 & 29.3 & 62.1 & 10.0 & 21.2 \\
\hline \multirow[t]{4}{*}{ NVAW02 } & Wed AM & 57.0 & 120.7 & 2.72 & 0.53 & 2.57 & 67.6 & 143.2 & 3.22 & 0.63 & 3.08 & 31.5 & 66.8 & 11.5 & 24.4 \\
\hline & Wed PM & 138.0 & 292.3 & 4.63 & 0.91 & 4.38 & 140.0 & 296.7 & 4.70 & 0.93 & 4.50 & 30.7 & 65.0 & 10.9 & 23.1 \\
\hline & Thur AM & 138.4 & 293.3 & 4.04 & 0.79 & 3.81 & 554.3 & 1174.3 & 16.16 & 3.18 & 15.28 & 25.2 & 53.3 & 7.5 & 15.8 \\
\hline & Thur PM & 43.5 & 92.1 & 1.54 & 0.30 & 1.45 & 129.9 & 275.1 & 4.59 & 0.90 & 4.34 & 20.2 & 42.7 & 5.0 & 10.5 \\
\hline \multirow[t]{4}{*}{ NVAW03 } & Wed AM & 92.0 & 194.9 & 3.90 & 0.77 & 3.69 & 255.6 & 541.5 & 10.84 & 2.13 & 10.26 & 33.4 & 70.8 & 12.9 & 27.3 \\
\hline & Wed PM & 98.9 & 209.6 & 4.97 & 0.98 & 4.70 & 199.0 & 421.6 & 10.01 & 1.97 & 9.49 & 39.7 & 84.2 & 18.0 & 38.1 \\
\hline & Thur AM & 49.3 & 104.4 & 3.40 & 0.67 & 3.21 & 83.5 & 176.9 & 5.76 & 1.13 & 5.47 & 42.3 & 89.5 & 20.3 & 43.0 \\
\hline & Thur PM & 88.3 & 187.0 & 5.14 & 1.01 & 4.85 & 249.5 & 528.5 & 14.52 & 2.86 & 13.74 & 55.5 & 117.6 & 34.7 & 73.6 \\
\hline \multirow[t]{3}{*}{ NYBS01 } & Wed AM & 51.6 & 109.4 & 2.02 & 0.40 & 2.08 & 105.6 & 223.8 & 4.14 & 0.82 & 4.28 & 25.4 & 53.8 & 7.4 & 15.6 \\
\hline & Wed PM & 78.2 & 165.6 & 1.84 & 0.36 & 1.89 & 158.1 & 335.0 & 3.72 & 0.73 & 3.84 & 22.8 & 48.3 & 6.0 & 12.8 \\
\hline & Thur AM & 84.5 & 179.1 & 2.43 & 0.48 & 2.50 & 124.5 & 263.8 & 3.58 & 0.70 & 3.71 & 22.4 & 47.4 & 5.8 & 12.4 \\
\hline \multirow{3}{*}{ NYBS02 } & Wed PM & 73.9 & 156.6 & 3.60 & 0.71 & 3.27 & 60.8 & 128.8 & 2.96 & 0.58 & 2.75 & 14.1 & 29.9 & 2.6 & 5.4 \\
\hline & Thur AM & 48.5 & 102.7 & 2.17 & 0.43 & 1.97 & 56.4 & 119.5 & 2.52 & 0.50 & 2.32 & 16.0 & 33.8 & 3.2 & 6.7 \\
\hline & Thur PM & 50.5 & 107.0 & 1.91 & 0.38 & 1.73 & 36.7 & 77.9 & 1.39 & 0.27 & 1.30 & & & & \\
\hline
\end{tabular}




\begin{tabular}{|c|c|c|c|c|c|c|c|c|c|c|c|c|c|c|c|}
\hline \multirow{3}{*}{$\begin{array}{c}\text { Study Space } \\
\text { ID }\end{array}$} & \multirow[b]{3}{*}{ Period } & \multicolumn{14}{|c|}{ OUTDOOR AIRFLOW } \\
\hline & & \multicolumn{5}{|c|}{$\mathrm{CO}_{2}$ Ratio } & \multicolumn{5}{|c|}{ Uncertainty in $\mathrm{CO}_{2}$ ratio $\mathrm{OA}$} & \multicolumn{2}{|c|}{ Peak $\mathrm{CO}_{2}$} & \multicolumn{2}{|c|}{$\begin{array}{c}\text { Uncertainty in peak } \mathrm{CO}_{2} \\
\mathrm{OA}\end{array}$} \\
\hline & & $\mathrm{L} / \mathrm{s} \bullet$ person & $\mathrm{cfm} /$ person & $\mathrm{L} / \mathrm{s} \cdot \mathrm{m}^{2}$ & $\mathrm{cfm} / \mathrm{ft}^{2}$ & $\mathrm{~h}^{-1}$ & L/s•person & cfm/person & $\mathrm{L} / \mathrm{s} \cdot \mathrm{m}^{2}$ & $\mathrm{cfm} / \mathrm{ft}^{2}$ & $\mathrm{~h}^{-1}$ & $\mathrm{~L} / \mathrm{s} \bullet$ person & $\mathrm{cfm} /$ person & $\mathrm{L} / \mathrm{s}$ •person & $\mathrm{cfm} /$ person \\
\hline \multirow{3}{*}{ NYBS04 } & Wed PM & 9.3 & 19.8 & 0.31 & 0.06 & 0.32 & 31.7 & 67.2 & 1.07 & 0.21 & 1.08 & 14.9 & 31.6 & 2.8 & 6.0 \\
\hline & Thur AM & 49.7 & 105.4 & 2.40 & 0.47 & 2.43 & 68.0 & 144.0 & 3.28 & 0.65 & 3.35 & 13.1 & 27.6 & 2.3 & 4.8 \\
\hline & Thur PM & 17.7 & 37.5 & 0.68 & 0.13 & 0.68 & 50.5 & 107.0 & 1.93 & 0.38 & 1.96 & 11.3 & 24.0 & 1.8 & 3.8 \\
\hline \multirow[t]{3}{*}{ NYBS05 } & Wed AM & 16.3 & 34.6 & 0.81 & 0.16 & 0.69 & 11.2 & 23.7 & 0.56 & 0.11 & 0.49 & 12.9 & 27.3 & 2.2 & 4.7 \\
\hline & Thur AM & 15.9 & 33.7 & 0.70 & 0.14 & 0.60 & 13.5 & 28.6 & 0.60 & 0.12 & 0.52 & 12.2 & 25.9 & 2.0 & 4.3 \\
\hline & Thur PM & 17.9 & 37.8 & 0.86 & 0.17 & 0.73 & 10.7 & 22.6 & 0.51 & 0.10 & 0.46 & & & & \\
\hline \multirow{4}{*}{ NYBS07 } & Wed AM & 36.9 & 78.1 & 1.95 & 0.38 & 1.81 & 70.9 & 150.2 & 3.75 & 0.74 & 3.49 & 19.0 & 40.3 & 4.3 & 9.2 \\
\hline & Wed PM & 58.9 & 124.8 & 2.21 & 0.43 & 2.05 & 58.8 & 124.7 & 2.21 & 0.43 & 2.08 & 22.1 & 46.8 & 5.7 & 12.1 \\
\hline & Thur AM & 38.0 & 80.6 & 1.83 & 0.36 & 1.70 & 72.3 & 153.1 & 3.47 & 0.68 & 3.23 & 21.9 & 46.3 & 5.6 & 11.8 \\
\hline & Thur PM & 7.4 & 15.8 & 0.30 & 0.06 & 0.28 & 52.8 & 111.9 & 2.13 & 0.42 & 1.98 & & & & \\
\hline \multirow[t]{3}{*}{ ORIS03 } & Wed AM & & & & & & & & & & & 38.3 & 81.2 & 16.8 & 35.5 \\
\hline & Wed PM & & & & & & & & & & & 38.2 & 81.0 & 16.7 & 35.4 \\
\hline & Thur AM & & & & & & & & & & & 44.1 & 93.4 & 22.0 & 46.7 \\
\hline \multirow[t]{4}{*}{ ORIS04 } & Wed AM & & & & & & & & & & & 122.6 & 259.8 & 167.7 & 355.3 \\
\hline & Wed PM & 69.2 & 146.7 & 2.65 & 0.52 & 2.85 & 147.6 & 312.7 & 5.65 & 1.11 & 6.10 & 41.2 & 87.3 & 19.3 & 40.9 \\
\hline & Thur AM & 103.1 & 218.4 & 4.55 & 0.89 & 4.88 & 234.1 & 495.9 & 10.32 & 2.03 & 11.12 & 213.4 & 452.1 & 506.7 & 1073.5 \\
\hline & Thur PM & 25.6 & 54.2 & 0.92 & 0.18 & 0.99 & 183.5 & 388.7 & 6.63 & 1.30 & 7.13 & 49.6 & 105.1 & 27.8 & 58.9 \\
\hline \multirow[t]{4}{*}{ PABS03 } & Wed AM & 24.1 & 51.1 & 0.69 & 0.14 & 0.68 & 38.9 & 82.4 & 1.11 & 0.22 & 1.10 & 14.4 & 30.5 & 2.7 & 5.8 \\
\hline & Wed PM & 0.0 & 0.0 & 0.00 & 0.00 & 0.00 & 43.2 & 91.5 & 1.17 & 0.23 & 1.15 & 14.4 & 30.6 & 2.7 & 5.8 \\
\hline & Thur AM & 10.7 & 22.7 & 0.29 & 0.06 & 0.28 & 38.0 & 80.5 & 1.03 & 0.20 & 1.01 & 13.6 & 28.8 & 2.5 & 5.2 \\
\hline & Thur PM & 6.1 & 13.0 & 0.18 & 0.04 & 0.18 & 43.4 & 91.9 & 1.29 & 0.25 & 1.27 & 13.9 & 29.4 & 2.5 & 5.4 \\
\hline \multirow[t]{4}{*}{ PABS04 } & Wed AM & 5.9 & 12.6 & 0.44 & 0.09 & 0.42 & 7.8 & 16.5 & 0.58 & 0.11 & 0.55 & 9.6 & 20.3 & 1.4 & 3.0 \\
\hline & Wed PM & 10.1 & 21.5 & 0.69 & 0.14 & 0.65 & 8.1 & 17.3 & 0.56 & 0.11 & 0.54 & 9.8 & 20.7 & 1.4 & 3.1 \\
\hline & Thur AM & 9.8 & 20.7 & 0.75 & 0.15 & 0.71 & 8.9 & 18.9 & 0.68 & 0.13 & 0.66 & 10.1 & 21.4 & 1.5 & 3.2 \\
\hline & Thur PM & 9.5 & 20.2 & 0.63 & 0.12 & 0.60 & 9.2 & 19.6 & 0.61 & 0.12 & 0.59 & 10.7 & 22.6 & 1.7 & 3.5 \\
\hline \multirow[t]{4}{*}{ SCDW01 } & Wed AM & 16.3 & 34.5 & 1.25 & 0.25 & 1.25 & 17.2 & 36.5 & 1.32 & 0.26 & 1.34 & 11.8 & 25.1 & 2.0 & 4.2 \\
\hline & Wed PM & & & & & & & & & & & 12.0 & 25.4 & 2.0 & 4.2 \\
\hline & Thur AM & 15.4 & 32.7 & 1.11 & 0.22 & 1.11 & 11.2 & 23.7 & 0.80 & 0.16 & 0.83 & 12.0 & 25.5 & 2.0 & 4.3 \\
\hline & Thur PM & 13.3 & 28.2 & 0.87 & 0.17 & 0.86 & 11.3 & 24.0 & 0.74 & 0.14 & 0.75 & & & & \\
\hline \multirow[t]{3}{*}{ SCDW02 } & Wed AM & 41.1 & 87.0 & 2.16 & 0.43 & 1.81 & 60.8 & 128.9 & 3.21 & 0.63 & 2.70 & 19.3 & 40.9 & 4.6 & 9.7 \\
\hline & Wed PM & 34.7 & 73.5 & 2.05 & 0.40 & 1.71 & 50.9 & 107.9 & 3.00 & 0.59 & 2.53 & 9.5 & 20.1 & 1.4 & 2.9 \\
\hline & Thur AM & 35.8 & 75.9 & 2.11 & 0.42 & 1.76 & 53.0 & 112.3 & 3.13 & 0.62 & 2.63 & 19.9 & 42.1 & 4.8 & 10.2 \\
\hline \multirow{3}{*}{ SDBW01 } & Wed PM & 58.8 & 124.5 & 1.95 & 0.38 & 2.16 & 58.0 & 122.9 & 1.93 & 0.38 & 2.17 & 19.1 & 40.5 & 4.4 & 9.3 \\
\hline & Thur AM & 34.9 & 73.9 & 1.28 & 0.25 & 1.42 & 40.2 & 85.2 & 1.48 & 0.29 & 1.66 & 17.7 & 37.5 & 3.8 & 8.1 \\
\hline & Thur PM & 50.5 & 107.0 & 1.86 & 0.37 & 2.06 & 52.8 & 111.8 & 1.94 & 0.38 & 2.18 & 19.5 & 41.2 & 4.5 & 9.6 \\
\hline
\end{tabular}




\begin{tabular}{|c|c|c|c|c|c|c|c|c|c|c|c|c|c|c|c|}
\hline \multirow{3}{*}{$\begin{array}{l}\text { Study Space } \\
\text { ID }\end{array}$} & \multirow[b]{3}{*}{ Period } & \multicolumn{14}{|c|}{ OUTDOOR AIRFLOW } \\
\hline & & \multicolumn{5}{|c|}{$\mathrm{CO}_{2}$ Ratio } & \multicolumn{5}{|c|}{ Uncertainty in $\mathrm{CO}_{2}$ ratio $\mathrm{OA}$} & \multicolumn{2}{|c|}{ Peak $\mathrm{CO}_{2}$} & \multicolumn{2}{|c|}{$\begin{array}{c}\text { Uncertainty in peak } \mathrm{CO}_{2} \\
\mathrm{OA}\end{array}$} \\
\hline & & $\mathrm{L} / \mathrm{s} \bullet$ person & $\mathrm{cfm} /$ person & $\mathrm{L} / \mathrm{s} \cdot \mathrm{m}^{2}$ & $\mathrm{cfm} / \mathrm{ft}^{2}$ & $\mathrm{~h}^{-1}$ & L/s•person & $\mathrm{cfm} /$ person & $\mathrm{L} / \mathrm{s} \cdot \mathrm{m}^{2}$ & $\mathrm{cfm} / \mathrm{ft}^{2}$ & $\mathrm{~h}^{-1}$ & L/s•person & cfm/person & L/s•person & $\mathrm{cfm} /$ person \\
\hline \multirow{3}{*}{ SDBW02 } & Wed PM & 80.8 & 171.3 & 1.48 & 0.29 & 1.64 & 64.1 & 135.8 & 1.18 & 0.23 & 1.33 & 20.2 & 42.9 & 4.9 & 10.3 \\
\hline & Thur AM & 41.5 & 88.0 & 1.21 & 0.24 & 1.34 & 62.3 & 132.1 & 1.82 & 0.36 & 2.03 & 18.7 & 39.7 & 4.2 & 8.9 \\
\hline & Thur PM & 33.7 & 71.4 & 0.84 & 0.17 & 0.93 & 49.5 & 104.8 & 1.24 & 0.24 & 1.38 & & & & \\
\hline \multirow[t]{3}{*}{ SDBW04 } & Wed AM & 20.6 & 43.6 & 1.05 & 0.21 & 1.17 & 97.5 & 206.6 & 4.96 & 0.98 & 5.55 & 19.0 & 40.2 & 4.3 & 9.2 \\
\hline & Thur AM & 31.5 & 66.8 & 1.28 & 0.25 & 1.43 & 112.6 & 238.5 & 4.56 & 0.90 & 5.11 & 26.5 & 56.2 & 8.0 & 17.0 \\
\hline & Thur PM & 30.2 & 64.1 & 1.51 & 0.30 & 1.69 & 86.8 & 183.9 & 4.33 & 0.85 & 4.85 & 23.8 & 50.4 & 6.5 & 13.8 \\
\hline \multirow[t]{4}{*}{ TNDS05 } & Wed AM & & & & & & & & & & & 18.1 & 38.4 & 4.1 & 8.6 \\
\hline & Wed PM & & & & & & & & & & & 21.3 & 45.1 & 5.5 & 11.6 \\
\hline & Thur AM & & & & & & & & & & & 20.2 & 42.9 & 5.0 & 10.6 \\
\hline & Thur PM & & & & & & & & & & & 26.4 & 55.9 & 8.2 & 17.4 \\
\hline \multirow[t]{3}{*}{ TNDS06 } & Wed AM & 22.4 & 47.5 & 0.73 & 0.14 & 0.66 & 28.2 & 59.7 & 0.91 & 0.18 & 0.83 & 13.8 & 29.2 & 2.5 & 5.3 \\
\hline & Wed PM & 26.2 & 55.6 & 0.75 & 0.15 & 0.68 & 22.7 & 48.1 & 0.65 & 0.13 & 0.60 & 13.3 & 28.2 & 2.4 & 5.1 \\
\hline & Thur AM & 8.7 & 18.4 & 0.43 & 0.08 & 0.39 & 12.7 & 26.8 & 0.63 & 0.12 & 0.57 & 15.8 & 33.4 & 3.2 & 6.7 \\
\hline \multirow[t]{4}{*}{ TNDS07 } & Wed AM & 0.0 & 0.0 & 0.00 & 0.00 & 0.00 & 93.4 & 197.8 & 3.94 & 0.78 & 4.24 & 23.0 & 48.7 & 6.3 & 13.4 \\
\hline & Wed PM & 17.6 & 37.3 & 1.07 & 0.21 & 1.15 & 50.9 & 107.8 & 3.10 & 0.61 & 3.34 & 19.5 & 41.3 & 4.6 & 9.8 \\
\hline & Thur AM & 0.0 & 0.0 & 0.00 & 0.00 & 0.00 & 49.8 & 105.5 & 3.16 & 0.62 & 3.39 & 18.2 & 38.6 & 4.1 & 8.7 \\
\hline & Thur PM & 0.0 & 0.0 & 0.00 & 0.00 & 0.00 & 65.4 & 138.6 & 3.98 & 0.78 & 4.28 & 18.1 & 38.4 & 4.1 & 8.6 \\
\hline \multirow[t]{4}{*}{ TNFS08 } & Wed AM & 17.0 & 36.1 & 0.94 & 0.19 & 1.01 & 8.7 & 18.4 & 0.48 & 0.09 & 0.54 & 10.5 & 22.3 & 1.6 & 3.4 \\
\hline & Wed PM & 18.7 & 39.6 & 0.77 & 0.15 & 0.83 & 11.7 & 24.8 & 0.48 & 0.10 & 0.54 & 10.0 & 21.2 & 1.5 & 3.1 \\
\hline & Thur AM & 13.9 & 29.4 & 0.77 & 0.15 & 0.82 & 9.9 & 20.9 & 0.55 & 0.11 & 0.60 & 10.2 & 21.7 & 1.5 & 3.2 \\
\hline & Thur PM & 14.7 & 31.2 & 0.80 & 0.16 & 0.86 & 12.3 & 26.1 & 0.67 & 0.13 & 0.74 & 10.1 & 21.4 & 1.5 & 3.2 \\
\hline \multirow[t]{4}{*}{ TNFS09 } & Wed AM & 7.2 & 15.2 & 0.62 & 0.12 & 0.64 & 8.1 & 17.1 & 0.70 & 0.14 & 0.73 & 10.1 & 21.4 & 1.5 & 3.2 \\
\hline & Wed PM & 6.3 & 13.3 & 0.40 & 0.08 & 0.41 & 9.4 & 20.0 & 0.59 & 0.12 & 0.61 & 9.2 & 19.6 & 1.3 & 2.8 \\
\hline & Thur AM & 6.4 & 13.6 & 0.50 & 0.10 & 0.51 & 7.4 & 15.6 & 0.57 & 0.11 & 0.60 & 9.9 & 21.0 & 1.5 & 3.1 \\
\hline & Thur PM & 5.8 & 12.3 & 0.45 & 0.09 & 0.46 & 5.1 & 10.8 & 0.39 & 0.08 & 0.41 & 8.4 & 17.9 & 1.1 & 2.4 \\
\hline \multirow[t]{4}{*}{ TNFS10 } & Wed AM & 78.3 & 165.8 & 3.93 & 0.77 & 3.26 & 85.1 & 180.3 & 4.28 & 0.84 & 3.58 & 23.8 & 50.5 & 6.6 & 13.9 \\
\hline & Wed PM & 62.5 & 132.4 & 3.25 & 0.64 & 2.69 & 121.3 & 257.1 & 6.31 & 1.24 & 5.24 & 21.1 & 44.6 & 5.2 & 11.1 \\
\hline & Thur AM & 89.0 & 188.6 & 4.16 & 0.82 & 3.44 & 84.9 & 179.9 & 3.97 & 0.78 & 3.34 & 28.1 & 59.6 & 9.0 & 19.0 \\
\hline & Thur PM & 60.8 & 128.9 & 3.22 & 0.63 & 2.66 & 108.7 & 230.2 & 5.75 & 1.13 & 4.78 & 26.1 & 55.2 & 7.8 & 16.4 \\
\hline \multirow[t]{3}{*}{ TXFS01 } & Wed AM & 6.6 & 14.0 & 0.22 & 0.04 & 0.18 & 18.8 & 39.7 & 0.62 & 0.12 & 0.51 & 13.1 & 27.7 & 2.3 & 4.9 \\
\hline & Wed PM & 7.4 & 15.7 & 0.25 & 0.05 & 0.21 & 17.0 & 36.0 & 0.58 & 0.11 & 0.48 & 8.8 & 18.7 & 1.2 & 2.6 \\
\hline & Thur AM & 7.6 & 16.1 & 0.31 & 0.06 & 0.25 & 21.9 & 46.4 & 0.88 & 0.17 & 0.73 & 13.7 & 29.1 & 2.5 & 5.3 \\
\hline \multirow{3}{*}{ TXFS02 } & Wed PM & 0.0 & 0.0 & 0.00 & 0.00 & 0.00 & 34.6 & 73.4 & 0.83 & 0.16 & 0.94 & 10.6 & 22.4 & 1.6 & 3.5 \\
\hline & Thur AM & 0.0 & 0.0 & 0.00 & 0.00 & 0.00 & 38.6 & 81.8 & 1.22 & 0.24 & 1.37 & 13.8 & 29.2 & 2.5 & 5.4 \\
\hline & Thur PM & 3.4 & 7.1 & 0.07 & 0.01 & 0.08 & 33.8 & 71.6 & 0.72 & 0.14 & 0.81 & 10.5 & 22.3 & 1.6 & 3.4 \\
\hline
\end{tabular}




\begin{tabular}{|c|c|c|c|c|c|c|c|c|c|c|c|c|c|c|c|}
\hline \multirow{3}{*}{$\begin{array}{c}\text { Study Space } \\
\text { ID }\end{array}$} & \multirow[b]{3}{*}{ Period } & \multicolumn{14}{|c|}{ OUTDOOR AIRFLOW } \\
\hline & & \multicolumn{5}{|c|}{$\mathrm{CO}_{2}$ Ratio } & \multicolumn{5}{|c|}{ Uncertainty in $\mathrm{CO}_{2}$ ratio $\mathrm{OA}$} & \multicolumn{2}{|c|}{ Peak $\mathrm{CO}_{2}$} & \multicolumn{2}{|c|}{$\begin{array}{c}\text { Uncertainty in peak } \mathrm{CO}_{2} \\
\mathrm{OA}\end{array}$} \\
\hline & & L/s•person & $\mathrm{cfm} /$ person & $\mathrm{L} / \mathrm{s} \cdot \mathrm{m}^{2}$ & $\mathrm{cfm} / \mathrm{ft}^{2}$ & $\mathrm{~h}^{-1}$ & L/s•person & cfm/person & $\mathrm{L} / \mathrm{s} \cdot \mathrm{m}^{2}$ & $\mathrm{cfm} / \mathrm{ft}^{2}$ & $\mathrm{~h}^{-1}$ & L/s•person & $\mathrm{cfm} /$ person & L/s•person & cfm/person \\
\hline \multirow[t]{4}{*}{ TXFS07 } & Wed AM & 6.5 & 13.8 & 0.56 & 0.11 & 0.65 & 17.9 & 38.0 & 1.54 & 0.30 & 1.77 & 13.4 & 28.5 & 2.4 & 5.0 \\
\hline & Wed PM & 13.3 & 28.2 & 1.13 & 0.22 & 1.30 & 16.3 & 34.6 & 1.39 & 0.27 & 1.61 & 12.0 & 25.5 & 2.0 & 4.2 \\
\hline & Thur AM & 11.2 & 23.8 & 0.94 & 0.19 & 1.08 & 13.7 & 29.0 & 1.15 & 0.23 & 1.33 & 12.7 & 26.8 & 2.1 & 4.5 \\
\hline & Thur PM & 7.7 & 16.3 & 0.75 & 0.15 & 0.86 & 13.9 & 29.3 & 1.35 & 0.27 & 1.56 & 12.8 & 27.2 & 2.2 & 4.6 \\
\hline \multirow[t]{4}{*}{ TXFS08 } & Wed AM & 8.5 & 18.1 & 0.31 & 0.06 & 0.35 & 13.5 & 28.5 & 0.49 & 0.10 & 0.56 & 8.7 & 18.4 & 1.2 & 2.5 \\
\hline & Wed PM & 8.9 & 19.0 & 0.32 & 0.06 & 0.37 & 14.5 & 30.7 & 0.52 & 0.10 & 0.60 & 6.4 & 13.5 & 0.8 & 1.6 \\
\hline & Thur AM & 9.5 & 20.2 & 0.27 & 0.05 & 0.31 & 20.3 & 43.0 & 0.58 & 0.11 & 0.67 & 8.0 & 17.0 & 1.1 & 2.2 \\
\hline & Thur PM & 10.9 & 23.0 & 0.41 & 0.08 & 0.46 & 11.2 & 23.8 & 0.42 & 0.08 & 0.49 & & & & \\
\hline \multirow[t]{4}{*}{ TXFS09 } & Wed AM & 21.2 & 44.9 & 0.61 & 0.12 & 0.59 & 21.6 & 45.7 & 0.63 & 0.12 & 0.61 & 8.1 & 17.1 & 1.1 & 2.3 \\
\hline & Wed PM & 35.3 & 74.8 & 0.86 & 0.17 & 0.82 & 13.9 & 29.5 & 0.34 & 0.07 & 0.35 & 6.3 & 13.4 & 0.8 & 1.6 \\
\hline & Thur AM & 20.8 & 44.2 & 0.54 & 0.11 & 0.52 & 21.2 & 44.8 & 0.55 & 0.11 & 0.54 & 8.3 & 17.6 & 1.1 & 2.4 \\
\hline & Thur PM & 19.3 & 40.9 & 0.54 & 0.11 & 0.52 & 13.2 & 28.0 & 0.37 & 0.07 & 0.37 & & & & \\
\hline \multirow[t]{3}{*}{$\begin{array}{l}\text { TXFW05 } \\
\end{array}$} & Wed AM & 26.9 & 57.0 & 1.02 & 0.20 & 1.16 & 34.3 & 72.6 & 1.31 & 0.26 & 1.50 & 20.1 & 42.5 & 4.9 & 10.4 \\
\hline & Wed PM & 18.7 & 39.6 & 0.76 & 0.15 & 0.87 & 28.7 & 60.7 & 1.17 & 0.23 & 1.34 & 14.2 & 30.0 & 2.6 & 5.6 \\
\hline & Thur AM & 9.1 & 19.3 & 0.38 & 0.07 & 0.43 & 26.1 & 55.3 & 1.08 & 0.21 & 1.23 & 29.8 & 63.2 & 10.3 & 21.9 \\
\hline \multirow[t]{4}{*}{ TXFW06 } & Wed AM & 95.5 & 202.3 & 2.26 & 0.45 & 2.57 & 163.2 & 345.7 & 3.86 & 0.76 & 4.41 & 34.3 & 72.7 & 13.5 & 28.7 \\
\hline & Wed PM & 131.0 & 277.5 & 2.85 & 0.56 & 3.23 & 176.1 & 373.0 & 3.83 & 0.75 & 4.38 & 22.8 & 48.2 & 6.2 & 13.1 \\
\hline & Thur AM & 93.0 & 197.1 & 2.32 & 0.46 & 2.64 & 85.8 & 181.7 & 2.14 & 0.42 & 2.48 & 20.6 & 43.6 & 5.1 & 10.9 \\
\hline & Thur PM & 160.6 & 340.2 & 2.61 & 0.51 & 2.96 & 148.1 & 313.7 & 2.40 & 0.47 & 2.78 & 17.8 & 37.6 & 3.9 & 8.3 \\
\hline \multirow[t]{4}{*}{ WAIW03 } & Wed AM & 35.4 & 75.0 & 1.22 & 0.24 & 1.25 & 21.8 & 46.2 & 0.75 & 0.15 & 0.80 & 16.1 & 34.2 & 3.3 & 7.0 \\
\hline & Wed PM & 72.4 & 153.4 & 2.00 & 0.39 & 2.06 & 47.9 & 101.5 & 1.32 & 0.26 & 1.41 & 14.4 & 30.5 & 2.7 & 5.8 \\
\hline & Thur AM & 46.0 & 97.5 & 1.61 & 0.32 & 1.65 & 46.6 & 98.8 & 1.63 & 0.32 & 1.70 & 17.5 & 37.1 & 3.8 & 8.1 \\
\hline & Thur PM & 70.8 & 150.0 & 1.96 & 0.39 & 2.01 & 53.5 & 113.3 & 1.48 & 0.29 & 1.56 & 16.8 & 35.6 & 3.6 & 7.5 \\
\hline \multirow[t]{4}{*}{ WAIW04 } & Wed AM & 36.2 & 76.8 & 0.77 & 0.15 & 0.74 & 40.2 & 85.1 & 0.86 & 0.17 & 0.83 & 14.2 & 30.0 & 2.6 & 5.6 \\
\hline & Wed PM & 40.9 & 86.6 & 1.07 & 0.21 & 1.03 & 30.7 & 65.0 & 0.80 & 0.16 & 0.79 & 13.6 & 28.8 & 2.5 & 5.2 \\
\hline & Thur AM & 25.3 & 53.7 & 0.64 & 0.13 & 0.62 & 26.9 & 57.1 & 0.68 & 0.13 & 0.66 & 14.7 & 31.2 & 2.8 & 6.0 \\
\hline & Thur PM & 29.3 & 62.0 & 0.72 & 0.14 & 0.69 & 24.2 & 51.3 & 0.60 & 0.12 & 0.58 & 13.6 & 28.9 & 2.5 & 5.2 \\
\hline \multicolumn{2}{|l|}{$\#$ of values } & 356 & & 358 & & 358 & & & & & & 353 & & & \\
\hline \multicolumn{2}{|l|}{ Mean } & 44.3 & 93.8 & 1.59 & 0.31 & 1.54 & 84.5 & 179.0 & 3.27 & 0.64 & 3.22 & 21.4 & 45.3 & 8.5 & 18.1 \\
\hline \multicolumn{2}{|l|}{ StdDev } & 47.4 & 100.5 & 1.55 & 0.31 & 1.51 & 111.1 & 235.4 & 5.76 & 1.13 & 5.98 & 16.6 & 35.3 & 29.7 & 62.9 \\
\hline \multicolumn{2}{|l|}{ Minimum } & 0.0 & 0.0 & 0.00 & 0.00 & 0.00 & 4.6 & 9.7 & 0.15 & 0.03 & 0.14 & 6.3 & 13.4 & 0.8 & 1.6 \\
\hline \multicolumn{2}{|l|}{ 10th percentile } & 5.3 & 11.3 & 0.20 & 0.04 & 0.19 & 13.6 & 28.8 & 0.60 & 0.12 & 0.58 & 10.0 & 21.3 & 1.5 & 3.1 \\
\hline 75th percentile & & 59.0 & 125.0 & 2.17 & 0.43 & 2.15 & 95.3 & 202.0 & 3.84 & 0.76 & 3.69 & 25.0 & 53.0 & 7.3 & 15.5 \\
\hline 90th percentile & & 95.7 & 202.8 & 3.89 & 0.77 & 3.56 & 199.5 & 422.6 & 6.99 & 1.38 & 6.89 & 33.3 & 70.7 & 12.6 & 26.6 \\
\hline Maximum & & 338.6 & 717.4 & 10.89 & 2.14 & 11.70 & 900.2 & 1907.2 & 82.69 & 16.27 & 88.84 & 213.4 & 452.1 & 506.7 & 1073.5 \\
\hline
\end{tabular}




\title{
Appendix F: Reanalysis of BASE Ventilation Data
}

This appendix presents the letter report published in October 2008 discussing the BASE ventilation data reanalysis that led to the revision of the original (2004) NIST report.

\section{Reanalysis of BASE Ventilation Data \\ Letter Report to U.S. Environmental Protection Agency October 10, 2008}

\author{
Andrew Persily \\ Building and Fire Research Laboratory \\ National Institute of Standards and Technology
}

\begin{abstract}
In 2004, the National Institute of Standards and Technology (NIST) published an analysis of the ventilation data collected as part of the U.S. Environmental Protection Agency (EPA) Building Assessment Survey and Evaluation (BASE) study [1]. That analysis provided a unique dataset of office building ventilation rates, both design and measured, along with many insights into building ventilation. The analysis also raised questions regarding the use of the difference between peak indoor carbon dioxide $\left(\mathrm{CO}_{2}\right)$ concentrations and the corresponding outdoor $\mathrm{CO}_{2}$ concentrations to estimate building ventilation rates, as there was a systematic difference between the ventilation rates based on this method and those based on duct traverse measurements. The current study examined the discrepancies between the peak indoor $\mathrm{CO}_{2-}$ based and traverse-based ventilation rates in more detail. In addition, the overall ventilation rate dataset was re-examined for consistency and, as a result, some errors were corrected.
\end{abstract}

\section{SUMMARY OF ANALYSIS AND REPORT CONTENT}

The BASE ventilation data reanalysis effort focused on two primary areas: 1) general corrections and adjustments to the original data; and 2) the disagreement between the outdoor air ventilation rates based on peak indoor $\mathrm{CO}_{2}$ concentrations and those based on traverse measurements at the air handlers (sometimes referred to as volumetric rates). The corrections involved a detailed review of the data files generated by National Institute of Standards and Technology (NIST) and provided to U.S. Environmental Protection Agency (EPA) for the BASE (Building Assessment Survey and Evaluation) CD distributed by EPA [2]. In addition, outliers (primarily those with high measured ventilation rates) were examined in more detail. Regarding the second issue, a number of potential explanations were examined for the differences between the ventilation rates estimated from peak indoor $\mathrm{CO}_{2}$ concentrations and the traverse-based or volumetric rates.

\section{DATABASE CORRECTIONS}

As part of the data review, the various files used in the ventilation data analysis were studied and compared with the files on the CD distributed by EPA [2]. As a result, a number of changes were made to the dataset, which are identified below. However, none of the changes modify the overall conclusions of the study, only some of the summary statistics. An updated version of the original NIST report on the dataset [1] will be published with these corrections. 
This data review effort involved a detailed examination of the data analysis files generated by the original analysis, including the following design parameters:

Supply capacity of each air handling unit (AHU)

AHU return capacity

Floor area served by each AHU

AHU design minimum outdoor air intake

Number of occupants served by each AHU

AHU supply capacity divided by floor area served

AHU design minimum outdoor air per person

AHU ratio of minimum outdoor air to supply capacity

Number of occupants per unit floor area (for each AHU)

Ratio of supply to return airflow (for each AHU)

In addition, the following measured parameters were also reviewed:

AHU supply airflow and associated uncertainty

AHU outdoor airflow and associated uncertainty

AHU recirculation airflow and associated uncertainty

AHU outdoor air intake fraction and associated uncertainty

Study space supply airflow per unit floor area and associated uncertainty

Study space outdoor airflow (per person, per unit floor area and per unit volume) and associated uncertainty

The changes made to the data files as a result of this effort are documented in Table 1.

\begin{tabular}{|c|c|c|c|}
\hline Building & Parameter & Modification & Comment \\
\hline CAJS01 & $\begin{array}{l}\text { Peak } \mathrm{CO}_{2} \text { value and } \\
\text { outdoor airflow } \\
\text { calculated from peak }\end{array}$ & All values deleted. & $\begin{array}{l}\text { All indoor } \mathrm{CO}_{2} \text { concentrations are } \\
\text { very erratic; two locations are } \\
\text { consistently below outdoors at } \\
\text { night. }\end{array}$ \\
\hline CAJW20 & $\begin{array}{l}\% \text { of AHU capacity } \\
\text { serving test space } \\
\left(\mathrm{C} 1 \mathrm{TS} 1 \mathrm{PCT}^{*}\right)\end{array}$ & $\begin{array}{l}\text { Changed from } 100 \% \text { to } \\
14 \%, \text { based on floor area } \\
\text { and number of occupants } \\
\text { served. }\end{array}$ & $\begin{array}{l}\text { Field notes indicate AHU serves } 7 \\
\text { floors, not } 1 \text { as indicated by } \\
\text { original value of C1TS1PCT. } \\
\text { Results in } 86 \% \text { reduction in supply } \\
\text { and outdoor airflows, and } \\
\text { associated reduction in uncertainty. }\end{array}$ \\
\hline CAJW24 & $\begin{array}{l}\text { Uncertainty in } \mathrm{CO}_{2} \\
\text { ratio outdoor airflow } \\
\text { per person. }\end{array}$ & $\begin{array}{l}\text { Fixed small error in } \\
\text { uncertainty in } \mathrm{L} / \mathrm{s} \bullet \text { person } \\
\text { and } \mathrm{cfm} / \text { person }\end{array}$ & $\begin{array}{l}\text { Roughly } 10 \% \text { reduction in these } \\
\text { two uncertainty values; no impact } \\
\text { on airflow results. }\end{array}$ \\
\hline MOCS01 & $\begin{array}{l}\text { Floor area served by } \\
\text { system }(\text { C7AAREA*) }\end{array}$ & $\begin{array}{l}\text { Increased by roughly a } \\
\text { factor of } 8 \text { (\# of building } \\
\text { floors) as listed value is } \\
\text { only for a single floor. }\end{array}$ & $\begin{array}{l}\text { Reduces design value of supply } \\
\text { airflow per unit floor area and } \\
\text { occupant density by factor of } 8 \text {. }\end{array}$ \\
\hline NCDW02 & $\begin{array}{l}\% \text { of AHU capacity } \\
\text { serving test space } \\
(\mathrm{C} 1 \mathrm{TS} 1 \mathrm{PCT})\end{array}$ & $\begin{array}{l}\text { Change from } 50 \% \text { to } \\
20 \% \text { for AHU \#1 and to } \\
30 \% \text { for AHU \#2, based } \\
\text { on floor area and number } \\
\text { of occupants served. }\end{array}$ & $\begin{array}{l}\text { Results in roughly } 50 \% \text { reduction } \\
\text { in reported supply and outdoor } \\
\text { airflows, and associated reduction } \\
\text { in uncertainties. }\end{array}$ \\
\hline PABS04 & $\begin{array}{l}\text { Design \# of occupants } \\
\text { (C7AOCCU) }\end{array}$ & $\begin{array}{l}\text { Replaced value of } 0 \text { with } \\
\text { blank cell for AHU \#2 }\end{array}$ & $\begin{array}{l}\text { AHU serves perimeter; occupants } \\
\text { accounted for by other systems. }\end{array}$ \\
\hline TNDS05 & $\begin{array}{l}\text { Design \# of occupants } \\
\text { (C7AOCCU) }\end{array}$ & $\begin{array}{l}\text { Replaced value of } 0 \text { with } \\
\text { blank cell for AHU \#2. }\end{array}$ & $\begin{array}{l}\text { AHU serves corridor; occupants } \\
\text { accounted for by other systems. }\end{array}$ \\
\hline
\end{tabular}




\begin{tabular}{|c|l|l|l|}
\hline TXFS02 & $\begin{array}{l}\text { Uncertainty in } \mathrm{CO}_{2} \\
\text { ratio outdoor airflow } \\
\text { per floor area. }\end{array}$ & $\begin{array}{l}\text { Fixed error in } \\
\text { uncertainty in } \mathrm{L} / \mathrm{s} \bullet \mathrm{m}^{2} \text { and } \\
\text { cfm/ft }\end{array}$
\end{tabular}$\quad$\begin{tabular}{l}
$\begin{array}{l}\text { Corrected uncertainty values ten } \\
\text { times uncorrected; no impact on } \\
\text { airflow results. }\end{array}$ \\
\hline
\end{tabular}

* Variable name from BASE data dictionary.

Table 1 Modifications to BASE ventilation data parameters

As a result of these modifications, some of the summary statistics in the original NIST report to EPA (NISTIR 7145) also change. The affected tables and figures are presented below, with the table and figure number from the original report in parentheses. In the tables, the revised values are highlighted in bold font.

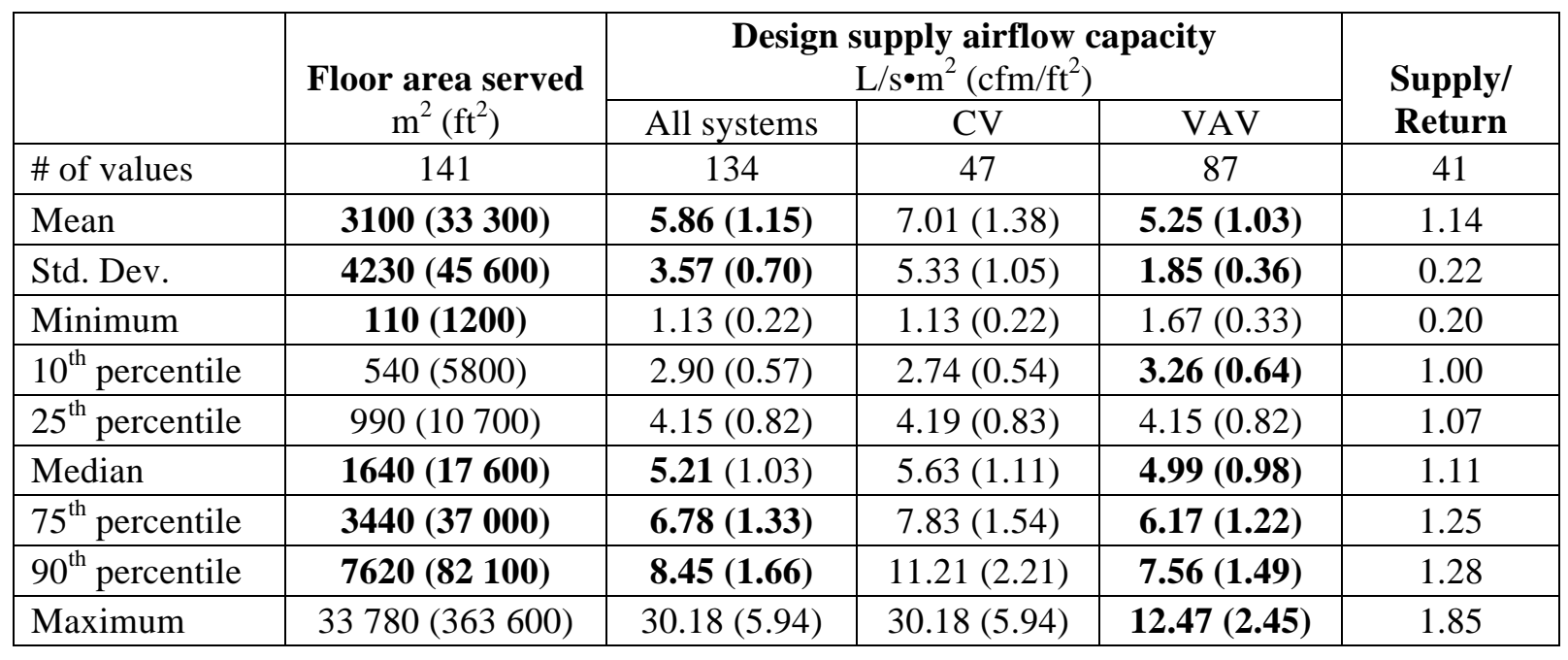

\begin{tabular}{|c|c|c|c|c|}
\hline & \multicolumn{2}{|c|}{ Design minimum outdoor air intake } & \multirow{2}{*}{$\begin{array}{l}\text { Minimum OA/ } \\
\text { Supply }\end{array}$} & \multirow{2}{*}{$\begin{array}{l}\text { Occupant density } \\
\# / 100 \mathrm{~m}^{2}\left(1000 \mathrm{ft}^{2}\right)\end{array}$} \\
\hline & $\mathrm{L} / \mathrm{s}(\mathrm{cfm})$ per person & $\mathrm{L} / \mathrm{s} \bullet \mathrm{m}^{2}\left(\mathrm{cfm} / \mathrm{ft}^{2}\right)$ & & \\
\hline \# of values & 74 & 76 & 76 & 137 \\
\hline Mean & $18.4(39.0)$ & $0.94(0.18)$ & 0.19 & $5.3(4.9)$ \\
\hline Std. Dev. & $13.7(29.0)$ & $1.06(0.21)$ & 0.22 & $6.5(6.1)$ \\
\hline Minimum & $1.3(2.9)$ & $0.17(0.03)$ & 0.06 & $0.9(0.8)$ \\
\hline $10^{\text {th }}$ percentile & $7.5(16.0)$ & $0.31(0.06)$ & 0.08 & $2.2(2.0)$ \\
\hline $25^{\text {th }}$ percentile & $10.6(22.4)$ & $0.42(0.08)$ & 0.10 & $2.9(2.7)$ \\
\hline Median & $15.2(32.1)$ & $0.60(0.12)$ & 0.12 & $3.9(3.7)$ \\
\hline $75^{\text {th }}$ percentile & $23.6(50.0)$ & $0.92(0.18)$ & 0.15 & $5.9(5.4)$ \\
\hline $90^{\text {th }}$ percentile & $29.7(63.0)$ & $1.82(0.36)$ & 0.31 & $8.0(7.4)$ \\
\hline Maximum & $98.3(208.2)$ & $6.67(1.31)$ & 1.00 & $65.1(60.5)$ \\
\hline
\end{tabular}

Table 2 System Design Values (Table 6 in NISTIR 7145) 


\begin{tabular}{|c|c|c|}
\hline System * & Issue & Comments \\
\hline AZHW10 (2 of 2) & $\begin{array}{l}\text { High supply capacity, } 24 \mathrm{~L} / \mathrm{s}^{\bullet} \mathrm{m}^{2} \\
\left(4.7 \mathrm{cfm} / \mathrm{ft}^{2}\right)\end{array}$ & System (1) at $8 \mathrm{~L} / \mathrm{s} \bullet \mathrm{m}^{2}\left(1.5 \mathrm{cfm} / \mathrm{ft}^{2}\right)$ \\
\hline LAGW05 (1 of 2) & $\begin{array}{l}\text { High supply capacity, } 18 \mathrm{~L} / \mathrm{s}^{\bullet} \mathrm{m}^{2} \\
\left(3.6 \mathrm{cfm} / \mathrm{ft}^{2}\right)\end{array}$ & $\begin{array}{l}\text { System (2) at } 4 \mathrm{~L} / \mathrm{s} \bullet \mathrm{m}^{2}\left(0.7 \mathrm{cfm} / \mathrm{ft}^{2}\right) \\
\text { occupant density } 5 \text { times that of system } \\
\text { (2); floor area could be low }\end{array}$ \\
\hline MOCSO1 (1 of 1) & $\begin{array}{l}\text { High supply capacity, } 27 \mathrm{~L} / \mathrm{s}^{\prime} \cdot \mathrm{m}^{2} \\
\left(5.3 \mathrm{cfm} / \mathrm{ft}^{z}\right)\end{array}$ & \\
\hline PABS04 (2 of 2$)$ & $\begin{array}{l}\text { High supply capacity, } 25 \mathrm{~L} / \mathrm{s}^{\bullet} \mathrm{m}^{2} \\
\left(5.9 \mathrm{cfm} / \mathrm{ft}^{2}\right)\end{array}$ & System (1) at $4 \mathrm{~L} / \mathrm{s} \bullet \mathrm{m}^{2}\left(0.8 \mathrm{cfm} / \mathrm{ft}^{2}\right)$ \\
\hline CAEW09 (1 of 1$)$ & $\begin{array}{l}\text { High minimum outdoor air } 53 \mathrm{~L} / \mathrm{s} \\
(113 \mathrm{cfm}) \text { per person, }\end{array}$ & $\begin{array}{l}\text { Minimum outdoor air based on supply and } \\
\text { return capacities }\end{array}$ \\
\hline CAJS21 (2 of 2) & $\begin{array}{l}\text { High minimum outdoor air, } 98 \mathrm{~L} / \mathrm{s} \\
(208 \mathrm{cfm}) \text { per person }\end{array}$ & $\begin{array}{l}100 \% \text { outdoor air system; System (1) at } \\
29 \mathrm{~L} / \mathrm{s}(61 \mathrm{cfm}) \text { per person }\end{array}$ \\
\hline MDDS01 (1 of 1) & $\begin{array}{l}\text { High minimum outdoor air, } 51 \mathrm{~L} / \mathrm{s} \\
(109 \mathrm{cfm}) \text { per person }\end{array}$ & \\
\hline NCDW03 (2 of 5) & $\begin{array}{l}\text { High minimum outdoor air, } 38 \mathrm{~L} / \mathrm{s} \\
(80 \mathrm{cfm}) \text { per person }\end{array}$ & $\begin{array}{l}\text { Other } 4 \text { systems from } 9 \mathrm{~L} / \mathrm{s}(20 \mathrm{cfm}) \text { per } \\
\text { person to } 16 \mathrm{~L} / \mathrm{s}(33 \mathrm{cfm}) \text { per person; } \\
\text { system }(2) \text { occupant density about } 25 \% \text { of } \\
\text { other } 4 \text { systems. }\end{array}$ \\
\hline NECW02 (1 of 1$)$ & $\begin{array}{l}\text { High minimum outdoor air, } 38 \mathrm{~L} / \mathrm{s} \\
(80 \mathrm{cfm}) \text { per person }\end{array}$ & $\begin{array}{l}\text { High occupant density, } 16 \text { occupants per } \\
100 \mathrm{~m}^{2}\left(1000 \mathrm{ft}^{2}\right)\end{array}$ \\
\hline TNFS10 ( 1 of 1$)$ & $\begin{array}{l}\text { High minimum outdoor air, } 34 \mathrm{~L} / \mathrm{s} \\
(72 \mathrm{cfm}) \text { per person }\end{array}$ & $\begin{array}{l}\text { Low occupant density, } 1.1 \text { occupants per } \\
100 \mathrm{~m}^{2}\left(1000 \mathrm{ft}^{2}\right)\end{array}$ \\
\hline CAJW25 (1 of 1$)$ & $\begin{array}{l}\text { High occupant density, } 61 \\
\text { occupants per } 100 \mathrm{~m}^{2}\left(1000 \mathrm{ft}^{2}\right)\end{array}$ & $\begin{array}{l}\text { Supply airflow } 24 \mathrm{~L} / \mathrm{s}^{\bullet} \mathrm{m}^{2}\left(2.5 \mathrm{cfm} / \mathrm{ft}^{2}\right) \text {; } \\
\text { floor area could be low }\end{array}$ \\
\hline MOCS01 (1 of 1) & $\begin{array}{l}\text { High occupant density, } 24 \\
\text { occupants per } 100 \mathrm{~m}^{2}\left(1000 \mathrm{ft}^{2}\right)\end{array}$ & \\
\hline NECW02 (1 of 1$)$ & $\begin{array}{l}\text { High occupant density, } 16 \\
\text { occupants per } 100 \mathrm{~m}^{2}\left(1000 \mathrm{ft}^{2}\right)\end{array}$ & \\
\hline SDBW02 (1 of 1) & $\begin{array}{l}\text { High occupant density, } 38 \\
\text { occupants per } 100 \mathrm{~m}^{2}\left(1000 \mathrm{ft}^{2}\right)\end{array}$ & $\begin{array}{l}\text { Low minimum outdoor air } 1 \mathrm{~L} / \mathrm{s}(3 \mathrm{cfm}) \\
\text { per person, consistent with high occupant } \\
\text { density value }\end{array}$ \\
\hline TNDS05 (1 of 2$)$ & $\begin{array}{l}\text { High occupant density, just over } \\
12 \text { occupants per } 100 \mathrm{~m}^{2}\left(1000 \mathrm{ft}^{2}\right)\end{array}$ & System (2) lists no occupants \\
\hline
\end{tabular}

* Values in parentheses refers to air handler number relative to total number of air handlers, e.g. (2 of 2) means second of two air handlers serving the study space.

\section{Table 3 System design outliers*}

(Table 7 in NISTIR 7145)

\footnotetext{
* The text in the table noted with a strikethrough corresponds to two occurrences that are no longer outliers given the modifications to the data described earlier.
} 


\begin{tabular}{|l|c|}
\hline & $\begin{array}{c}\text { Study space outdoor air requirement } \\
\text { L/s (cfm) per person }\end{array}$ \\
\hline Mean & $\mathbf{9 . 0}(\mathbf{1 9 . 1})$ \\
\hline Std. Dev. & $\mathbf{3 . 3}(\mathbf{6 . 9})$ \\
\hline Minimum & $4.8(10.2)$ \\
\hline $10^{\text {th }}$ percentile & $\mathbf{6 . 5}(\mathbf{1 3 . 7 )}$ \\
\hline $25^{\text {th }}$ percentile & $7.2(15.3)$ \\
\hline Median & $8.7(18.3)$ \\
\hline $75^{\text {th }}$ percentile & $10.0(21.1)$ \\
\hline $90^{\text {th }}$ percentile & $\mathbf{1 2 . 1}(\mathbf{2 5 . 7 )}$ \\
\hline Maximum & $33.5(71.0)$ \\
\hline
\end{tabular}

Table 4 Study space outdoor air requirements based on Standard 62 addendum n

(Table 8 in NISTIR 7145)

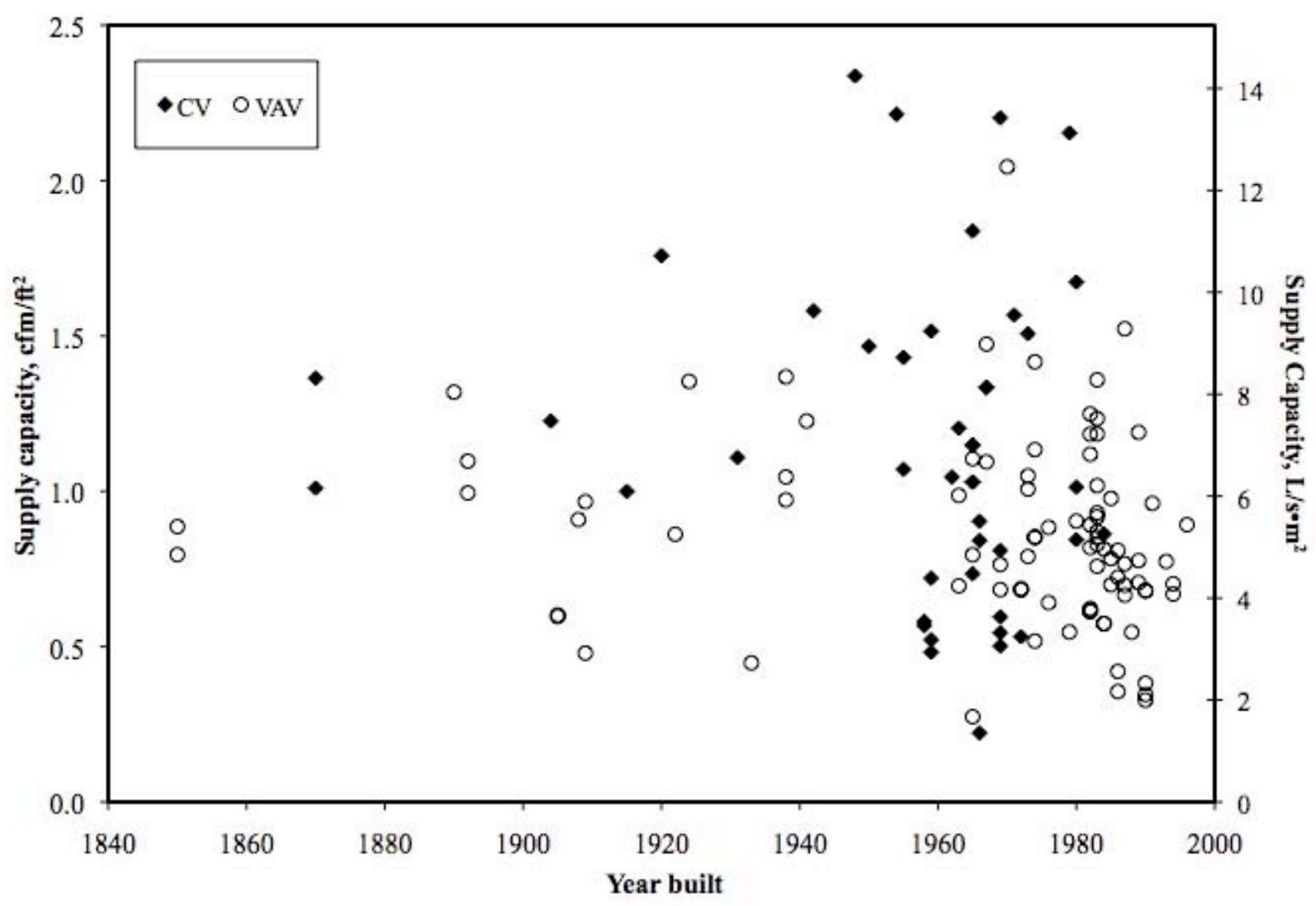

Figure 1 Design supply airflow capacity versus year built

(Figure 3 in NISTIR 7145) 


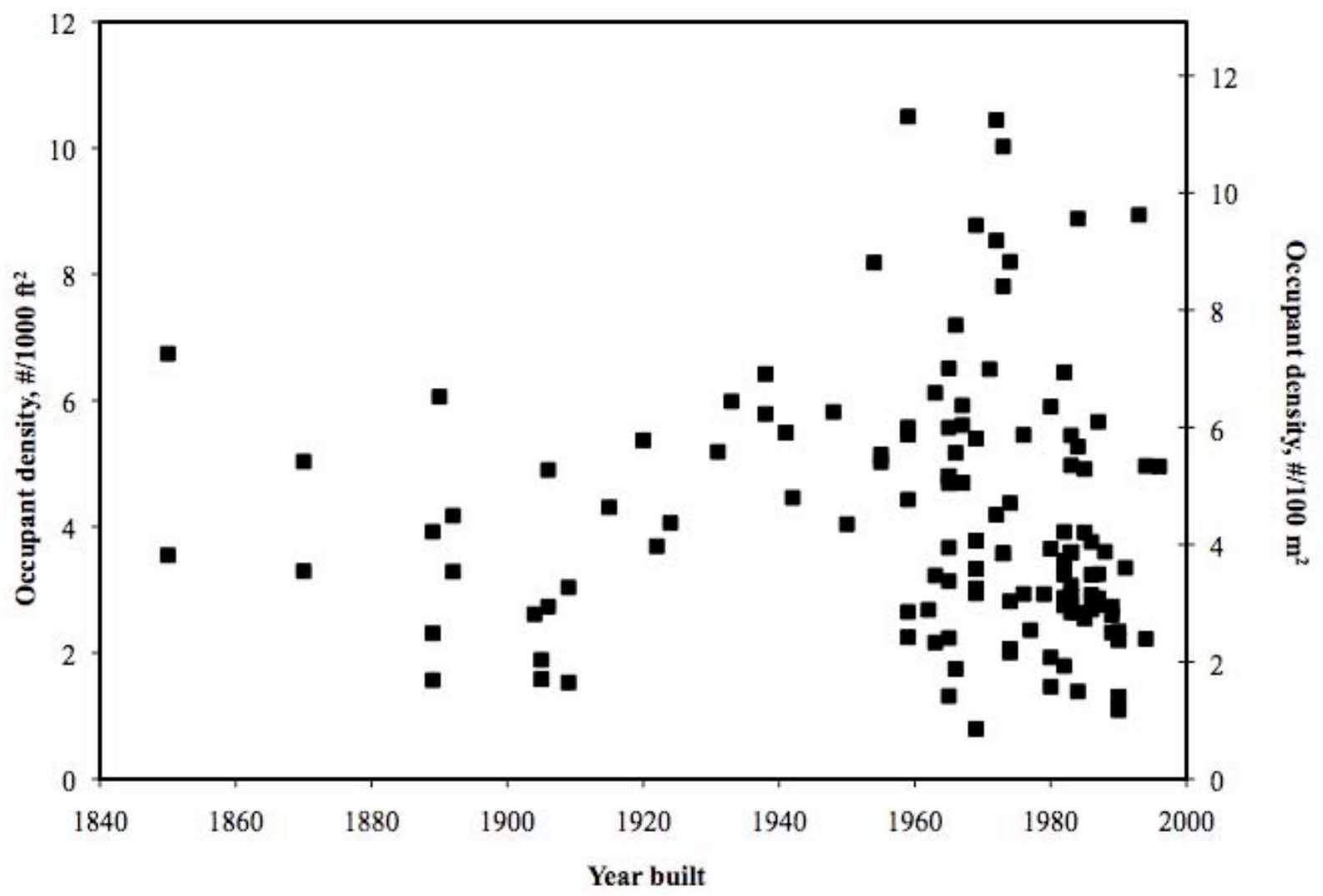

Figure 2 Design occupant density versus year built (Figure 5 in NISTIR 7145)

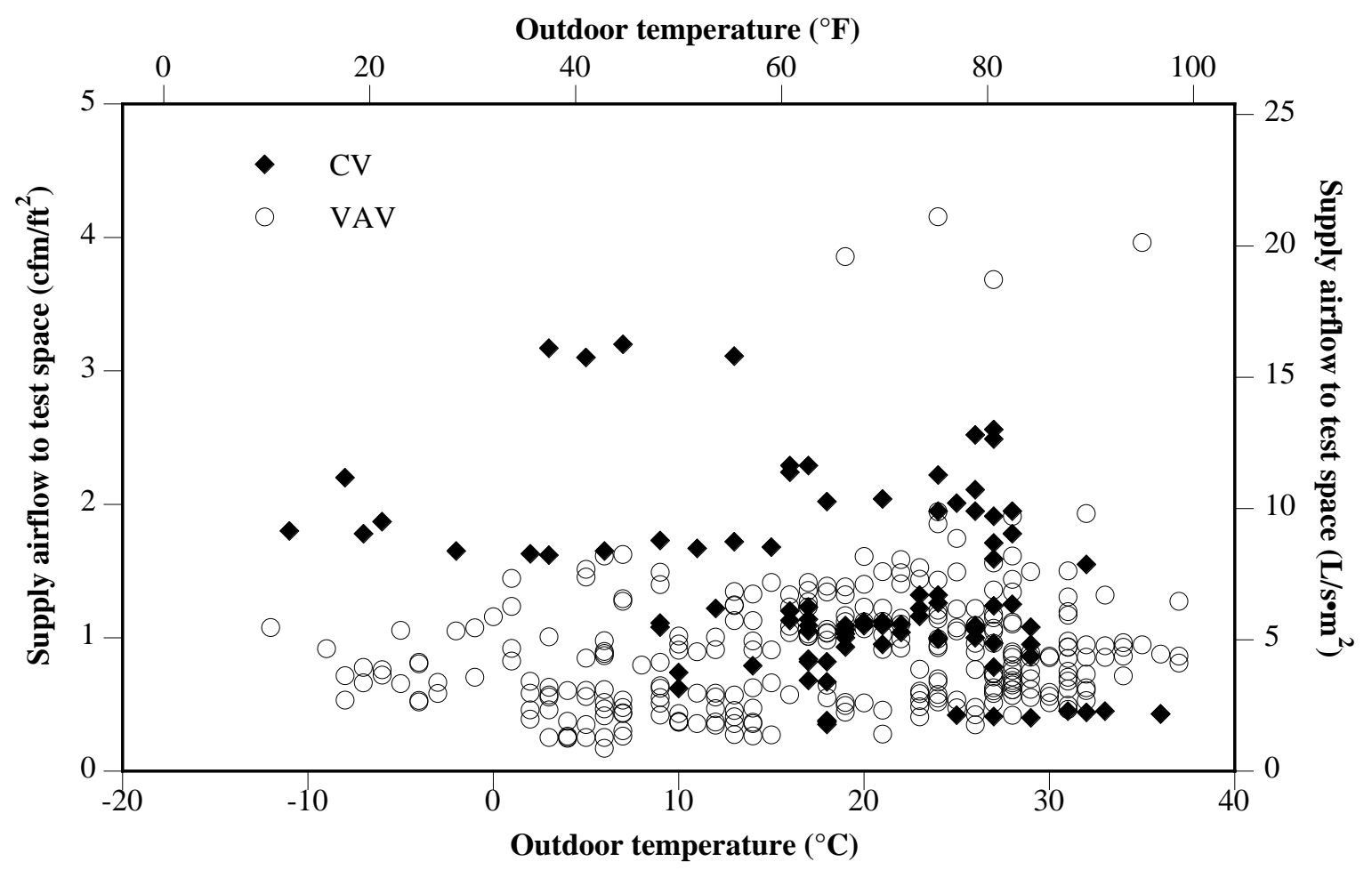

Figure 3 Measured study space supply airflow vs. outdoor temperature

(Figure 7 in NISTIR 7145) 


\begin{tabular}{|l|c|c|c|}
\hline & \multicolumn{3}{|c|}{$\begin{array}{c}\text { Supply airflow/Floor area } \\
\mathrm{L} / \mathrm{s}^{\bullet} \mathrm{m}^{2}\left(\mathrm{cfm} / \mathrm{ft}^{2}\right)\end{array}$} \\
\hline & All systems & VAV & CV \\
\hline \# of values & 384 & 289 & 95 \\
\hline Mean & $\mathbf{5 . 1 2}(\mathbf{1 . 0 1})$ & $\mathbf{4 . 5 5}(\mathbf{0 . 9 0})$ & $6.86(1.35)$ \\
\hline Std. Dev. & $\mathbf{3 . 0 2}(\mathbf{0 . 5 9})$ & $\mathbf{2 . 6 2}(\mathbf{0 . 5 2})$ & $3.46(0.68)$ \\
\hline Minimum & $0.88(0.17)$ & $0.88(0.17)$ & $1.80(0.35)$ \\
\hline $10^{\text {th }}$ percentile & $\mathbf{2 . 1 6 ( 0 . 4 3 )}$ & $\mathbf{2 . 1 2 ( \mathbf { 0 . 4 2 } )}$ & $2.25(0.44)$ \\
\hline $25^{\text {th }}$ percentile & $\mathbf{2 . 9 9}(\mathbf{0 . 5 9})$ & $\mathbf{2 . 8 9}(\mathbf{0 . 5 7})$ & $4.82(0.95)$ \\
\hline Median & $\mathbf{4 . 6 9}(\mathbf{0 . 9 2})$ & $\mathbf{4 . 3 0}(\mathbf{0 . 8 5})$ & $5.72(1.13)$ \\
\hline $75^{\text {th }}$ percentile & $\mathbf{6 . 2 5}(\mathbf{1 . 2 3})$ & $\mathbf{5 . 6 9}(\mathbf{1 . 1 2})$ & $9.04(1.78)$ \\
\hline $90^{\text {th }}$ percentile & $\mathbf{8 . 4 7}(\mathbf{1 . 6 7})$ & $\mathbf{7 . 1 9}(\mathbf{1 . 4 1})$ & $11.34(2.23)$ \\
\hline Maximum & $21.11(4.15)$ & $21.11(4.15)$ & $16.24(3.20)$ \\
\hline
\end{tabular}

Table 5 Summary of measured supply airflows (Table 13 in NISTIR 7145)

\begin{tabular}{|l|c|c|}
\hline & Best volumetric & Carbon dioxide \\
\hline \# of values & $\mathbf{5 0 9}$ & 520 \\
\hline Mean & $\mathbf{0 . 3 8}$ & 0.31 \\
\hline Standard deviation & 0.35 & 0.27 \\
\hline Minimum & 0.00 & 0.00 \\
\hline $10^{\text {th }}$ percentile & 0.04 & 0.03 \\
\hline $25^{\text {th }}$ percentile & 0.10 & 0.11 \\
\hline Median & 0.22 & 0.23 \\
\hline $75^{\text {th }}$ percentile & 0.59 & 0.44 \\
\hline $90^{\text {th }}$ percentile & 1.00 & 0.75 \\
\hline Maximum & $\mathbf{1 . 5 2}$ & 1.20 \\
\hline
\end{tabular}

Table 6 Summary of measured outdoor air fraction (Table 14 in NISTIR 7145) 


\begin{tabular}{|l|c|c|c|}
\hline & $\begin{array}{c}\text { Per person } \\
\mathrm{L} / \mathrm{s}(\mathrm{cfm}) \text { per person }\end{array}$ & $\begin{array}{c}\text { Per unit floor area } \\
\mathrm{L} / \mathrm{s} \bullet \mathrm{m}^{2}\left(\mathrm{cfm} / \mathrm{ft}^{2}\right)\end{array}$ & $\begin{array}{c}\text { Air changes per } \\
\text { hour, } \mathrm{h}^{-1}\end{array}$ \\
\hline \# of values & 367 & 369 & 369 \\
\hline Mean & $\mathbf{4 9}(\mathbf{1 0 5})$ & $\mathbf{1 . 8 7}(\mathbf{0 . 3 7})$ & $\mathbf{1 . 8 3}$ \\
\hline Std. Dev. & $\mathbf{5 4 ( 1 1 4 )}$ & $\mathbf{2 . 0 8}(\mathbf{0 . 4 1})$ & $\mathbf{2 . 0 7}$ \\
\hline Minimum & $0(0)$ & $0(0)$ & 0.00 \\
\hline $10^{\text {th }}$ percentile & $6(13)$ & $0.24(0.05)$ & 0.22 \\
\hline $25^{\text {th }}$ percentile & $13(27)$ & $0.50(0.10)$ & 0.47 \\
\hline Median & $30(63)$ & $1.03(0.20)$ & 0.98 \\
\hline $75^{\text {th }}$ percentile & $\mathbf{6 6}(\mathbf{1 4 0})$ & $\mathbf{2 . 3 0}(\mathbf{0 . 4 5})$ & $\mathbf{2 . 4 6}$ \\
\hline $90^{\text {th }}$ percentile & $\mathbf{1 1 6}(\mathbf{2 4 5})$ & $\mathbf{4 . 6 4}(\mathbf{0 . 9 1})$ & $\mathbf{4 . 4 6}$ \\
\hline Maximum & $\mathbf{3 1 0}(\mathbf{6 5 7})$ & $\mathbf{1 2 . 3 1}(\mathbf{2 . 4 2})$ & $\mathbf{1 3 . 2 3}$ \\
\hline
\end{tabular}

Table 7 Summary of Measured Outdoor Air Ventilation - Volumetric (Table 15 in NISTIR 7145)

\begin{tabular}{|l|c|}
\hline & $\begin{array}{c}\text { Outdoor air per person, } \\
\text { L/s (cfm) }\end{array}$ \\
\hline \# of values & 356 \\
\hline Mean & $\mathbf{4 4 ( 9 4 )}$ \\
\hline Std. Dev. & $\mathbf{4 7}(\mathbf{1 0 1})$ \\
\hline Minimum & $0(0)$ \\
\hline $10^{\text {th }}$ percentile & $5(11)$ \\
\hline $25^{\text {th }}$ percentile & $12(26)$ \\
\hline Median & $31(65)$ \\
\hline $75^{\text {th }}$ percentile & $\mathbf{5 9}(\mathbf{1 2 5})$ \\
\hline $90^{\text {th }}$ percentile & $\mathbf{9 6}(\mathbf{2 0 3})$ \\
\hline Maximum & $\mathbf{3 3 9}(\mathbf{7 1 7})$ \\
\hline
\end{tabular}

Table 8 Summary of Measured Outdoor Air Ventilation - $\mathrm{CO}_{2}$ Ratio (Table 16 in NISTIR 7145) 


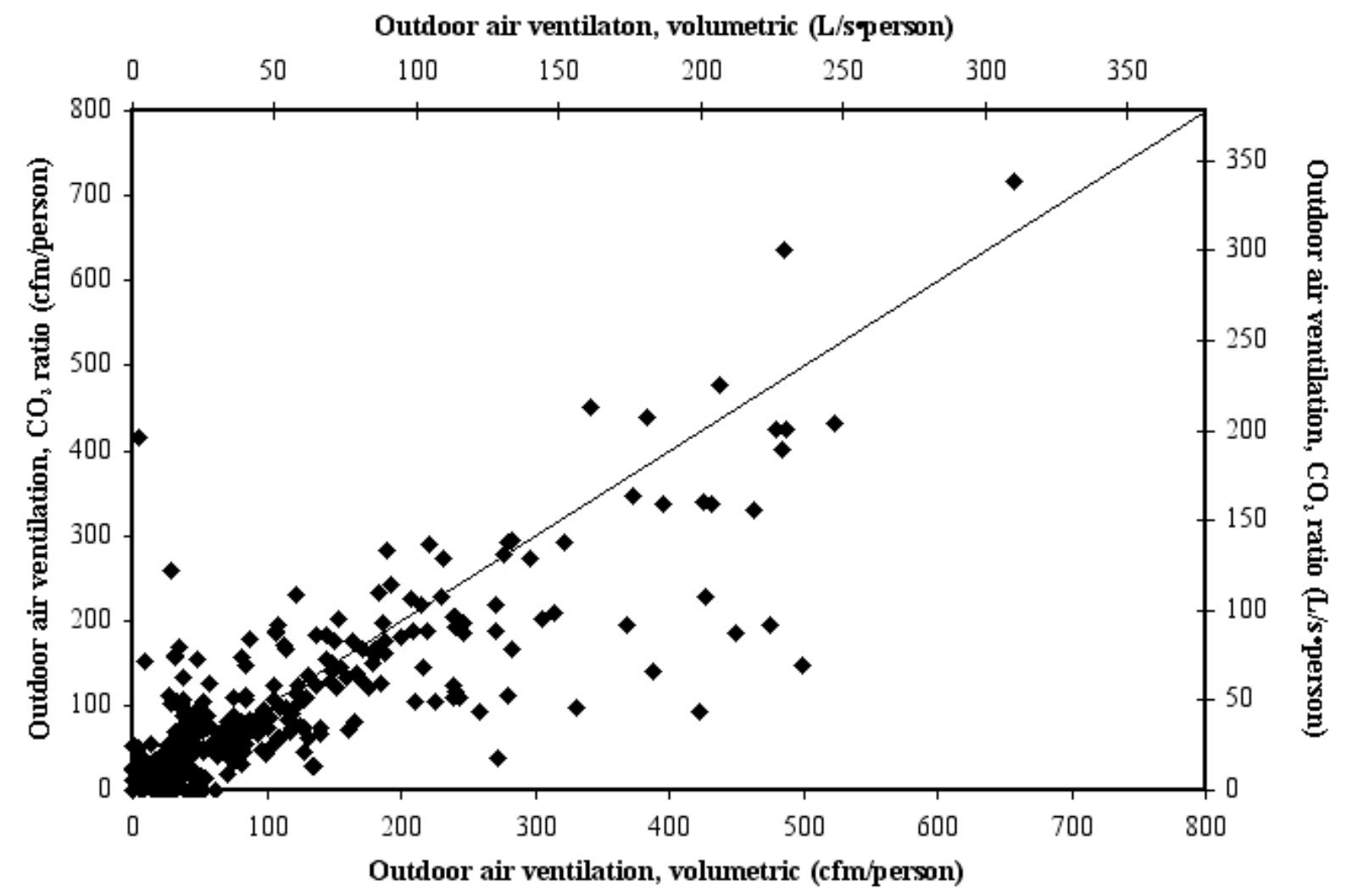

Figure 4 Outdoor air ventilation, $\mathrm{CO}_{2}$-ratio vs. volumetric

(Figure 14 in NISTIR 7145)

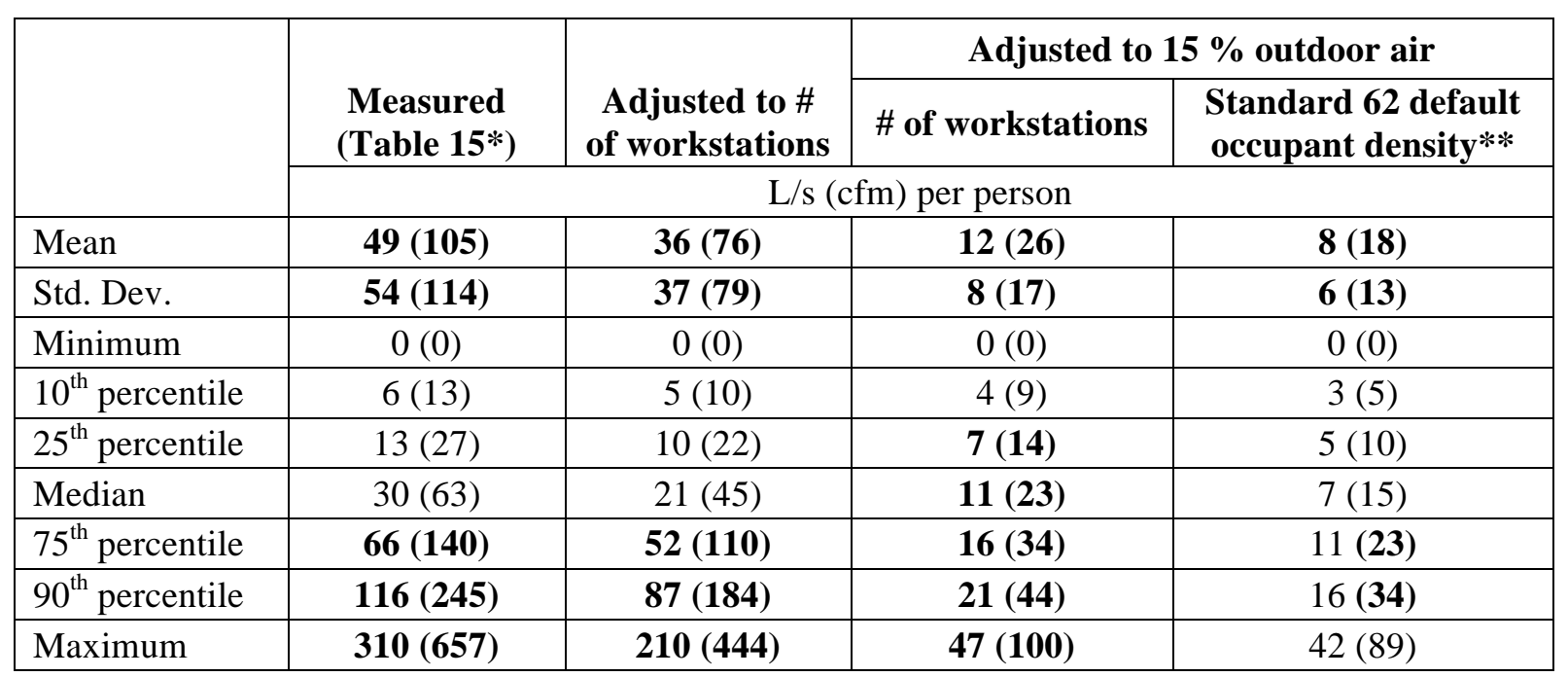

* Refers to Table 15 in the original report.

** Adjustment based on default occupant density in Standard 62.12001 (same as 1989) and not in 2004 and 2007 versions.

Table 9 Outdoor air ventilation adjusted for occupancy and outdoor air fraction

(Table 17 in NISTIR 7145) 


\begin{tabular}{|l|c|c|c|}
\hline & \multicolumn{3}{|c|}{ Outdoor air ventilation, L/s (cfm) per person } \\
\hline & All peak $\mathbf{C O}_{2}$ data & $\begin{array}{c}\text { Peak CO2 data on } \\
\text { "test days" }\end{array}$ & $\begin{array}{c}\text { Volumetric results from } \\
\text { Table 15* }\end{array}$ \\
\hline \# of values & $\mathbf{5 4 8}$ & $\mathbf{3 5 3}$ & 367 \\
\hline Mean & $\mathbf{2 0}(\mathbf{4 3})$ & $\mathbf{2 1}(\mathbf{4 5})$ & $\mathbf{4 9}(\mathbf{1 0 5})$ \\
\hline Std. Dev. & $\mathbf{1 4 ( 3 1 )}$ & $\mathbf{1 7}(\mathbf{3 5})$ & $\mathbf{5 4}(\mathbf{1 1 4})$ \\
\hline Minimum & $6(13)$ & $6(13)$ & $0(0)$ \\
\hline $10^{\text {th }}$ percentile & $10(20)$ & $10(21)$ & $6(13)$ \\
\hline $25^{\text {th }}$ percentile & $12(26)$ & $13(27)$ & $13(27)$ \\
\hline Median & $18(\mathbf{3 7})$ & $18(\mathbf{3 8})$ & $30(63)$ \\
\hline $75^{\text {th }}$ percentile & $24(\mathbf{5 0})$ & $25(\mathbf{5 3})$ & $\mathbf{6 6}(\mathbf{1 4 0})$ \\
\hline $90^{\text {th }}$ percentile & $\mathbf{3 2}(\mathbf{6 8})$ & $\mathbf{3 3}(\mathbf{7 1})$ & $\mathbf{1 1 6}(\mathbf{2 4 5})$ \\
\hline Maximum & $213(452)$ & $213(452)$ & $\mathbf{3 1 0}(\mathbf{6 5 7})$ \\
\hline
\end{tabular}

* Refers to Table 15 in the original report.

Table 10 Summary of Measured Outdoor Air Ventilation - Peak $\mathrm{CO}_{2}$

(Table 18 in NISTIR 7145)

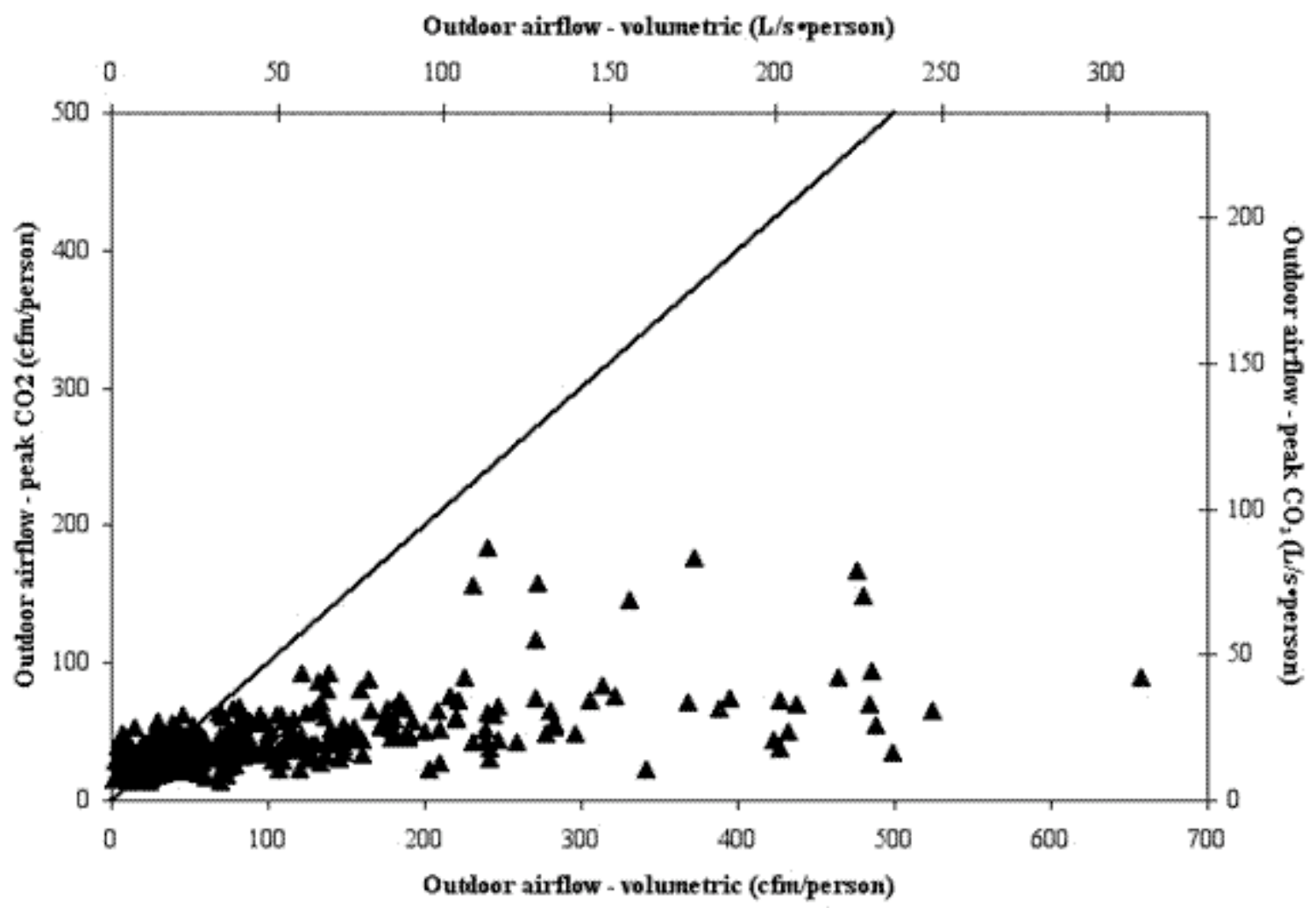

Figure 5 Outdoor air ventilation, $\mathrm{CO}_{2}$ peak vs. volumetric

(Figure 15 in NISTIR 7145) 
In reviewing the data, the issue of low values of traverse measurements of airflow was examined but no changes were made to the dataset as a result. For the airflow traverses, the concern is the accuracy of the anemometer or pitot tube measurements at lower air speeds. While a small number of traverse measurements of airflow are in the range of $50 \mathrm{~L} / \mathrm{s}(100 \mathrm{cfm})$, it is actually the air speed measured in the duct that is most relevant to its accuracy. For the supply duct traverses, the mean measured air speed is $5.3 \mathrm{~m} / \mathrm{s}(1000 \mathrm{ft} / \mathrm{min})$, which is within the range at which such measurements are expected to be accurate. A small number of the air speeds are low enough to be of potential concern, but less than $1 \%$ are below $0.3 \mathrm{~m} / \mathrm{s}(60 \mathrm{ft} / \mathrm{min})$. The mean air speed for the outdoor air intake traverses is $3.1 \mathrm{~m} / \mathrm{s}(600 \mathrm{ft} / \mathrm{min})$, again in a reliable range, with only about $3 \%$ below about $0.3 \mathrm{~m} / \mathrm{s}(60 \mathrm{ft} / \mathrm{min})$. No modifications were made to the dataset to eliminate the low readings, but given the small number of such values, their removal would not have a major effect on the overall conclusions of the study.

\section{OUTDOOR AIRFLOW: COMPARISON OF PEAK INDOOR CO2-BASED AND DUCT TRAVERSE-BASED VALUES}

A key finding of the original study, and a primary motivation for this reanalysis, is the consistent difference between the outdoor airflow rates based on the duct traverse measurements and the estimates based on peak $\mathrm{CO}_{2}$ concentrations in the study spaces. The latter estimates were based on indoor $\mathrm{CO}_{2}$ concentrations measured continuously during several days of the study period using 3 to 4 fixed monitors distributed randomly in the study space. The concentrations were then averaged and peak values of those averages were determined for each morning and afternoon. This approach to ventilation rate estimation has been used for a number of years though often without a complete understanding of the assumptions inherent in the method [3]. The peak indoor $\mathrm{CO}_{2}$ method for estimating outdoor air ventilation rates is essentially a singlezone, constant injection tracer gas technique. Therefore, it is based on the assumption that the indoor $\mathrm{CO}_{2}$ concentration is uniform throughout the study space and that the test space is isolated from the rest of the building or that the rest of the building is at the same $\mathrm{CO}_{2}$ concentration as the study space. In addition, the approach as typically applied assumes that the indoor $\mathrm{CO}_{2}$ concentration is at steady-state and that the following quantities are constant: outdoor concentration, ventilation airflow rate, and building occupancy. The validity of these assumptions was not assessed as part of the BASE study and most of them cannot be assessed based on the available data.

As seen in Figure 5 above (corrected Figure 15 from the original report), for volumetric (traverse-based) outdoor airflow rates above about $20 \mathrm{~L} / \mathrm{s} \bullet$ person (40 cfm/person), the values based on peak $\mathrm{CO}_{2}$ concentrations are consistently lower than the volumetric values. This issue was discussed in the original report as follows:

"The reason that the peak $\mathrm{CO}_{2}$ values tend to be lower than expected has been investigated, but no explanation has yet been verified. Considering the methodology behind the peak $\mathrm{CO}_{2}$ analysis, one might suspect the lack of steady-state $\mathrm{CO}_{2}$ concentrations could be impacting the agreement between the two values. However, steady state is more likely to occur at the higher ventilation rates due to the shorter system time constants, resulting in better agreement at higher rates, which is contrary to what is seen in Figure 15. Another potential explanation is the existence of significant $\mathrm{CO}_{2}$ concentration gradients within the study spaces, as well as between them and adjoining spaces, given that the single-zone analysis method assumes a uniform concentration within the zone and neglects interzone transfer of $\mathrm{CO}_{2}$. While it is 
certainly possible that the $\mathrm{CO}_{2}$ concentrations were different in adjoining zones, one would expect the impact to be positive in some cases and negative in others. However, the differences in the data tend to all be in one direction. The level of agreement was examined in those study spaces that corresponded to an entire building, for which concentration differences in adjoining spaces are not an issue, and the peak $\mathrm{CO}_{2}$ and volumetric ventilation rates were not observed to agree any better. Note that the fixed $\mathrm{CO}_{2}$ monitors in the study spaces were placed at a height of $1.1 \mathrm{~m}$ (43 in.) above the floor and at locations representative of workstation layout and work activities, i.e., locations in hallways and passageways were intentionally avoided (EPA 2003) ${ }^{1}$. Given these guidelines on location, it is possible that the measured $\mathrm{CO}_{2}$ concentrations are higher than the study-space average. If the measured $\mathrm{CO}_{2}$ concentration is indeed higher than the true space average, then the calculated ventilation rates would be low relative to their actual value. Also, it is reasonable to expect that the lack of uniformity would be more pronounced at higher outdoor air ventilation with less recirculation of return air, leading to the observed increase in errors. However, it is not possible to verify the magnitude of the concentration nonuniformity in these spaces based on the available data, and therefore it cannot be confirmed whether this is necessarily a valid explanation for the observed differences. The peak $\mathrm{CO}_{2}$ concentrations were examined with the issue of nonuniformity in mind, and it was determined that the actual average concentration in the study space would have to be $360 \mathrm{mg} / \mathrm{m}^{3}$ to $720 \mathrm{mg} / \mathrm{m}^{3}$ (200 ppm(v) to $400 \mathrm{ppm}(\mathrm{v})$ ) lower than that measured by the fixed monitors to explain the observed differences."

Figure 15 in the original report actually included only a subset of the values, i.e., those with volumetric outdoor air ventilation rates less than $200 \mathrm{~L} / \mathrm{s} \bullet$ person $(400 \mathrm{cfm} /$ person). The corrected version above in Figure 5 contains all the points in the corrected dataset. The corrected dataset includes many outdoor airflow values with high uncertainties. These uncertainties were calculated using standard approaches to the propagation of error in which the estimated uncertainties in the values used to calculate the airflows were propagated through the mathematical operations used to determine the airflow rates. Note that these uncertainty estimates do not account for biases in the measurement methods or the impact of the assumptions behind the peak $\mathrm{CO}_{2}$ method not being valid. For the volumetric values, the mean value of the ratio of the uncertainty in the outdoor airflow per person to the corresponding measured value is close to 1.1; the median ratio is about 0.3 . The mean ratio of the uncertainty to the measured value for the peak indoor $\mathrm{CO}_{2}$-based values is much smaller, about 0.3 , and there are values over 1.0. The relative uncertainties for the volumetric flows tend to be larger due in part to the existence of a small number of measurement events with very low outdoor airflow rates but very high uncertainties. These high uncertainty cases occur when the outdoor airflow is determined by subtracting the recirculation airflow from the supply.

Figure 6 is a plot of the same data shown in Figure 5, but with only those values for which the ratio of the uncertainty to the measured value is less than one. These data exhibit less scatter than that seen in Figure 5. Figure 7 restricts the data plotted even further to values for which the ratio is less than 0.5 . This plot is particularly striking in the very flat distribution of the data in which the volumetric values range from $0 \mathrm{~L} / \mathrm{s}$-person to about $250 \mathrm{~L} / \mathrm{s}$-person $(500 \mathrm{cfm} /$ person $)$ while the peak indoor $\mathrm{CO}_{2}$-based values cover a much more narrow range from about $7 \mathrm{~L} / \mathrm{s}$-person (15 cfm/person) to $35 \mathrm{~L} / \mathrm{s} \bullet$ person $(74 \mathrm{cfm} /$ person). The ratio of the standard deviation to the

\footnotetext{
${ }^{1}$ This is reference number 4 in the list of references for this report.
} 
mean for the values in Figure 7 is 1.0 for the volumetric rates but only 0.4 for the peak $\mathrm{CO}_{2}$ values. The lack of variability in the peak $\mathrm{CO}_{2}$ values relative to the volumetric rates is notable and is discussed further below.

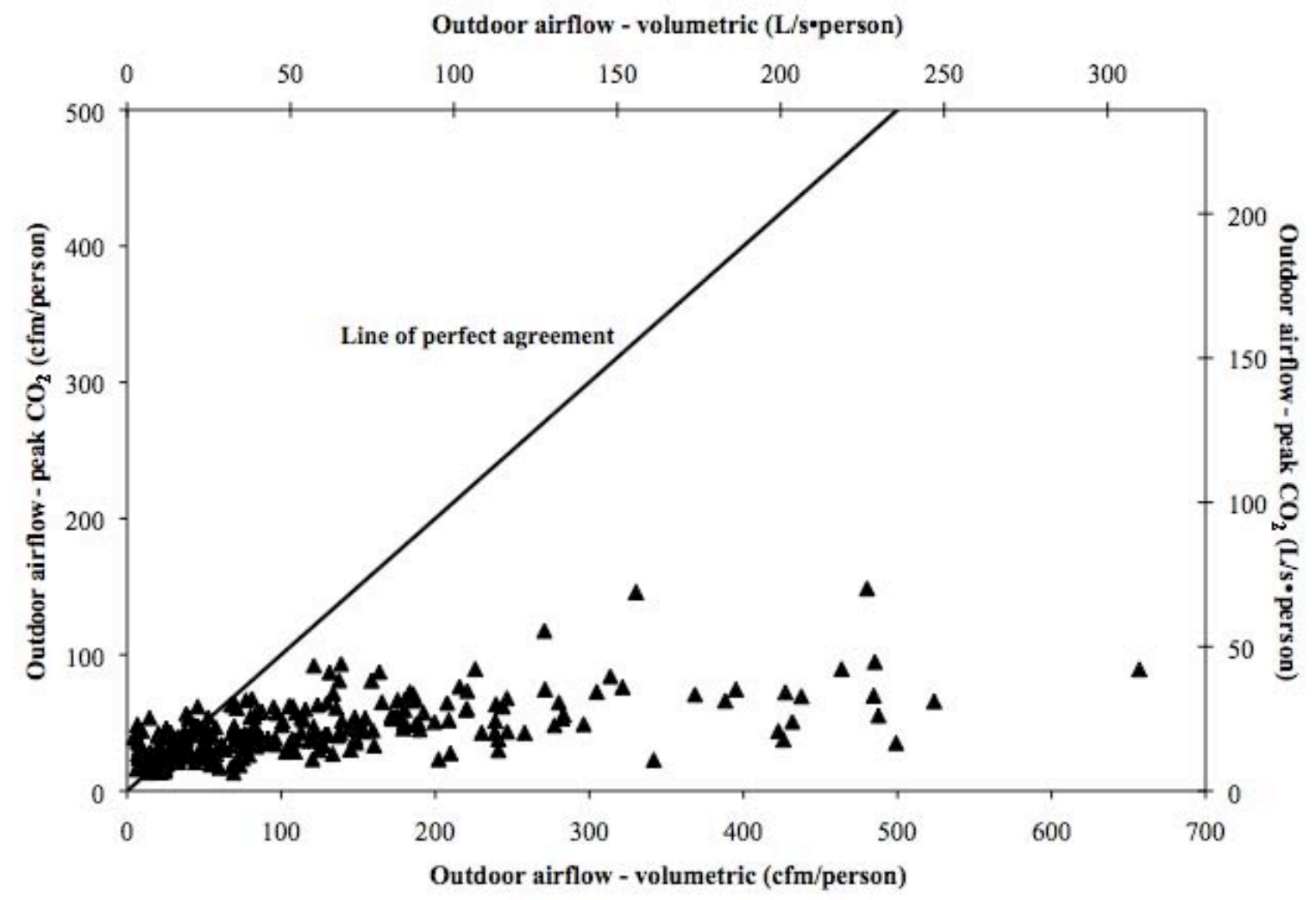

Figure 6 Updated - Outdoor air ventilation, $\mathrm{CO}_{2}$ peak vs. volumetric (relative uncertainty < 1) 


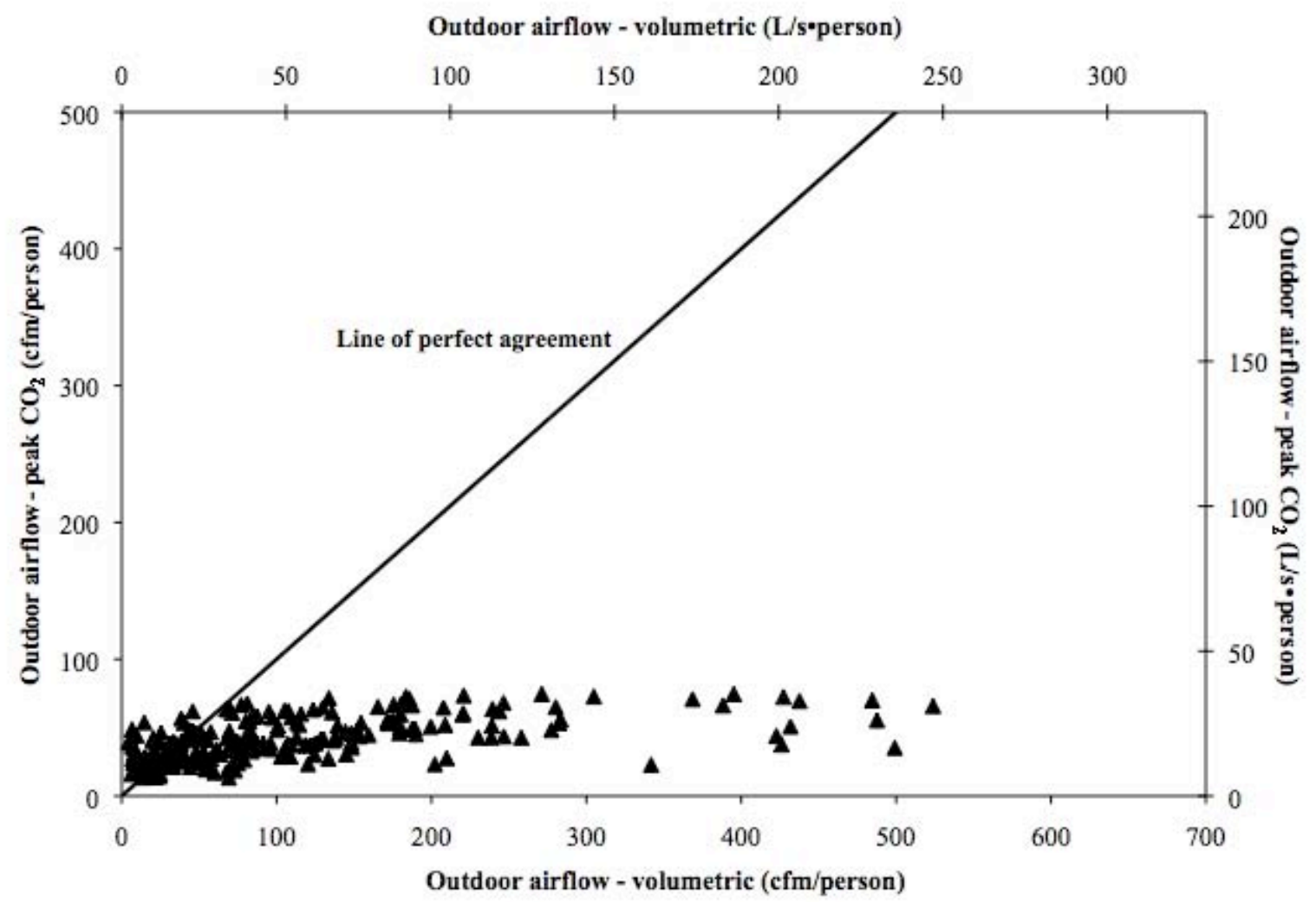

Figure 7 Updated - Outdoor air ventilation, $\mathrm{CO}_{2}$ peak vs. volumetric (rel. uncertainty $<0.5$ )

Nonuniform $\mathrm{CO}_{2}$ concentrations

As noted in the original report, one potential explanation for the discrepancy between the traverse and peak $\mathrm{CO}_{2}$ rates is nonuniformity in the $\mathrm{CO}_{2}$ concentrations in the space.

Specifically, the fact that the $\mathrm{CO}_{2}$ concentrations were sampled "at a height of $1.1 \mathrm{~m}$ (43 in.) above the floor and at locations representative of workstation layout and work activities" raises the question of whether the readings were impacted by the occupants' local exhalations. In addition, the BASE protocol requires that these monitoring locations be selected among $5 \mathrm{~m}$ by $5 \mathrm{~m}$ grids of which more than $50 \%$ of the area is occupied full time [4]. $\mathrm{CO}_{2}$ concentrations in the exhaled breath from people are in the range of $72000 \mathrm{mg} / \mathrm{m}^{3}$ (40 $\left.000 \mathrm{ppm}(\mathrm{v})\right)$ [3], which is well above the concentrations measured in the study spaces. Therefore the proximity of occupants to the indoor monitoring locations does lead to the potential for the measured concentrations being elevated relative to the space average.

The issue of nonuniform concentration was evaluated in two ways, by comparing the space concentrations to those measured in the air handler returns and by examining the uniformity among the various sample locations in each study space.

As part of the ventilation evaluations, $\mathrm{CO}_{2}$ concentrations were measured on four occasions during the test week (typically on Wednesday and Thursday of the study week in the morning and afternoon) in the air handler return, supply, and outdoor airstreams to calculate the outdoor air intake fraction based on a mass balance of $\mathrm{CO}_{2}$ in the air handler. These discrete measurements of $\mathrm{CO}_{2}$ in the return were compared with the average of the concentrations in the study space taken at the same time, which is generally not the same time as peak in the study 
space concentration. Note that the return airstreams sometimes contained air drawn from other spaces in addition to the study space, therefore the comparisons were only made for study spaces served by a dedicated air handler, i.e., an air handler that doesn't serve any other spaces. Figure 8 is a plot of the space concentration versus the corresponding concentration in the air handler return (open squares) as well as the difference between the space and return concentrations again plotted against the return concentration (open circles). The space concentrations do tend to exceed the return concentrations, though there are a small number of cases for which the space concentration is lower. The average difference for the 183 cases where both values exist equals $108 \mathrm{mg} / \mathrm{m}^{3}$ (60 ppm(v)). The differences tend be higher for lower return concentrations, which correspond to higher ventilation rates. These higher ventilation rates are associated with higher outdoor air intake fractions, which result in less mixing of the indoor air and are consistent with the greater differences between space and return concentrations.

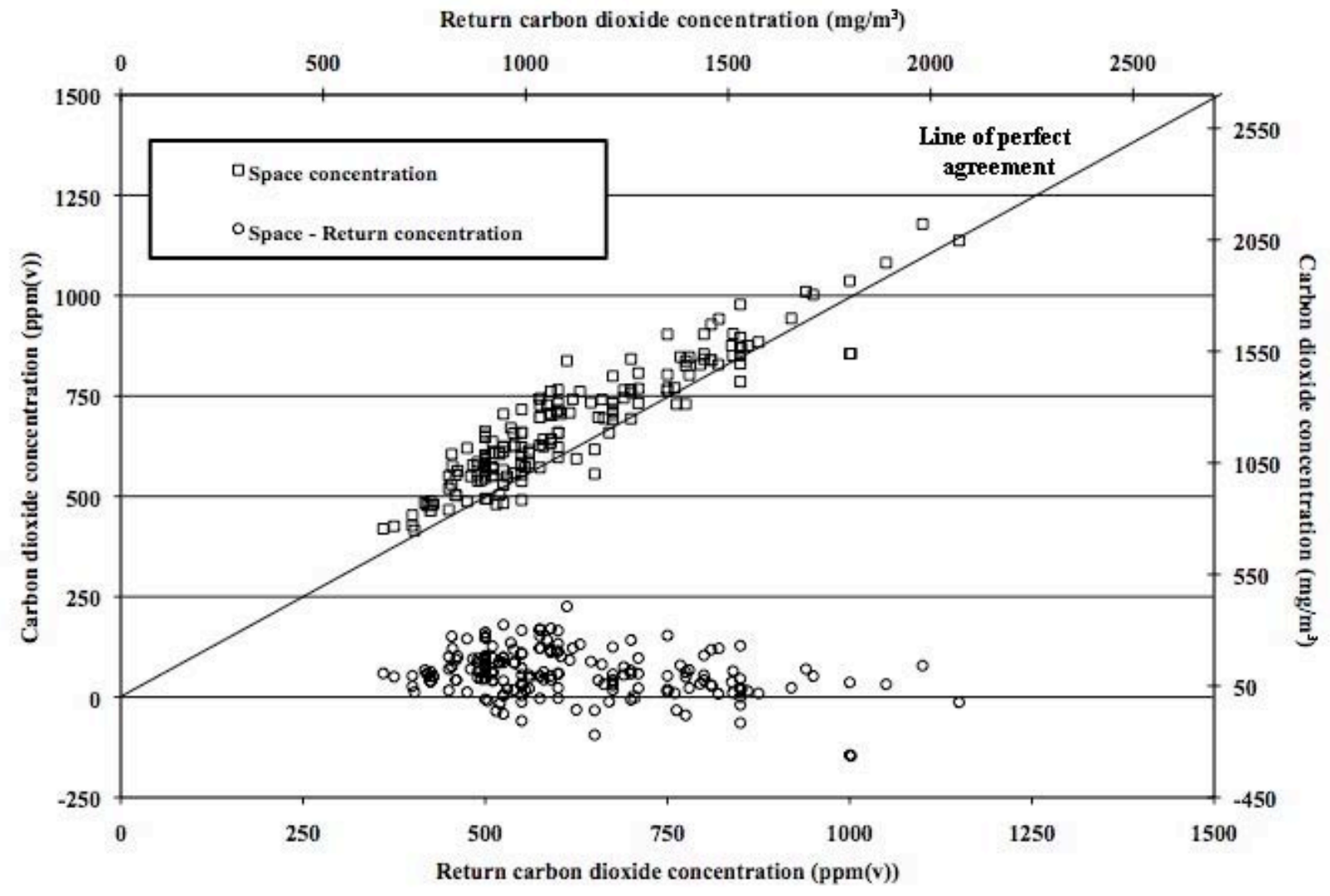

Figure 8 Space and space-minus-return $\mathrm{CO}_{2}$ concentrations vs. return concentration

The return versus space concentration differences were also examined for study spaces that correspond to an entire building. One might expect the concentration differences to be more clearly defined in such situations because there is no interzone airflow and $\mathrm{CO}_{2}$ transport to confound the return-versus-space relationship. However, those study spaces revealed no significant differences relative to other spaces.

Some of the buildings tested later in the BASE project were also subject to continuous measurements of $\mathrm{CO}_{2}$ in the air handler returns. Several of these datasets were examined for systematic differences between the study space and air handler return peak $\mathrm{CO}_{2}$ concentrations. 
The results were largely consistent with those seen between the space and spot measurements in the return.

While the observed differences between the return and space concentrations indicate that the space concentrations may be elevated due to the presence of occupants, the magnitude of the impact is not sufficient to explain the observed differences between the volumetric and peak $\mathrm{CO}_{2}$ based ventilation rates. Figure 9 is a plot of the peak $\mathrm{CO}_{2}$ rates adjusted using the average spacereturn difference of $108 \mathrm{mg} / \mathrm{m}^{3}(60 \mathrm{ppm}(\mathrm{v}))$, i.e., with the peak space concentration reduced by that average difference. In this figure, the adjusted rates are superimposed on the unadjusted data from Figure 6.

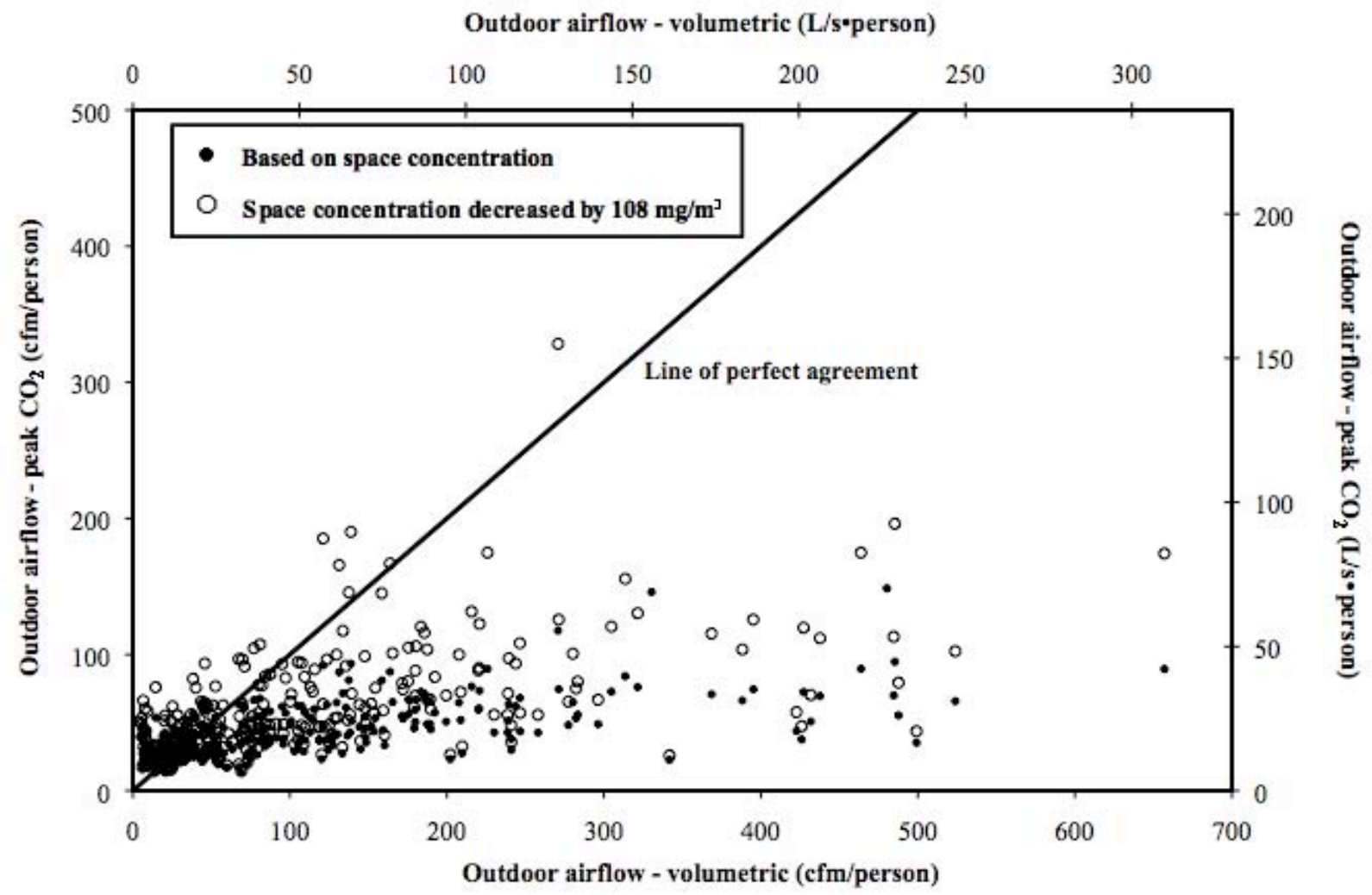

Figure $9 \mathrm{CO}_{2}$ peak vs. volumetric ventilation rate adjusted for space-return concentration

The second approach used to examine the issue of nonuniform $\mathrm{CO}_{2}$ concentrations in the study spaces was to consider the concentration variations within the space. As noted earlier, the $\mathrm{CO}_{2}$ concentrations were measured at multiple locations in each study space, and the concentrations among these locations varied. In an attempt to examine the impact of those nonuniformities, the ventilation rates were recalculated using the $\mathrm{CO}_{2}$ sampling location that yielded the lowest peak value. Figure 10 is a plot of the measured $\mathrm{CO}_{2}$ concentrations for study space MIBW03, including the outdoor and three indoor locations. The difference between the indoor locations is evident in this plot. Note that ASTM D6245 [3] requires that $\mathrm{CO}_{2}$ concentrations within the study space not vary from the space average by more than $10 \%$ when estimating ventilation rates based on peak $\mathrm{CO}_{2}$ concentrations. This requirement is not met for this study space and for many of the other BASE study spaces. 


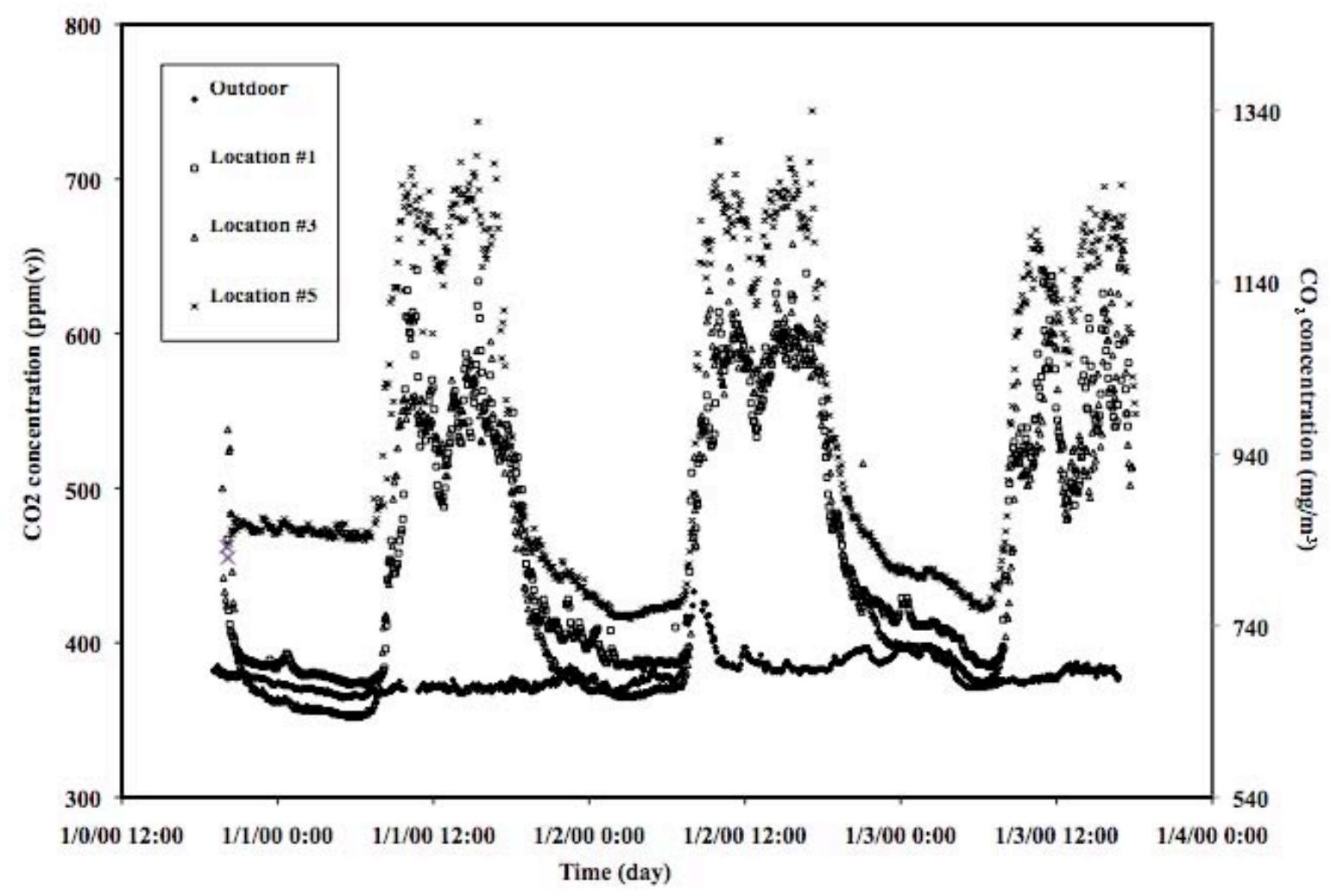

Figure 10 Variation in $\mathrm{CO}_{2}$ concentrations among indoor locations (study space MIBW03)

For each study space, the indoor location with the lowest peak $\mathrm{CO}_{2}$ value was used to estimate the outdoor air ventilation values. Figure 11 is a plot of the outdoor airflows estimated using the monitoring location with the minimum peak $\mathrm{CO}_{2}$ value against the volumetric rates, with the airflows based on the peak average $\mathrm{CO}_{2}$ concentration from Figure 6 included as well. Using the minimum peak $\mathrm{CO}_{2}$ concentrations does increase the outdoor airflow values, but not enough to result in good agreement with the volumetric values. The improvement is more pronounced than that seen for the adjustment based on the average return-space concentration difference seen in Figure 9. 


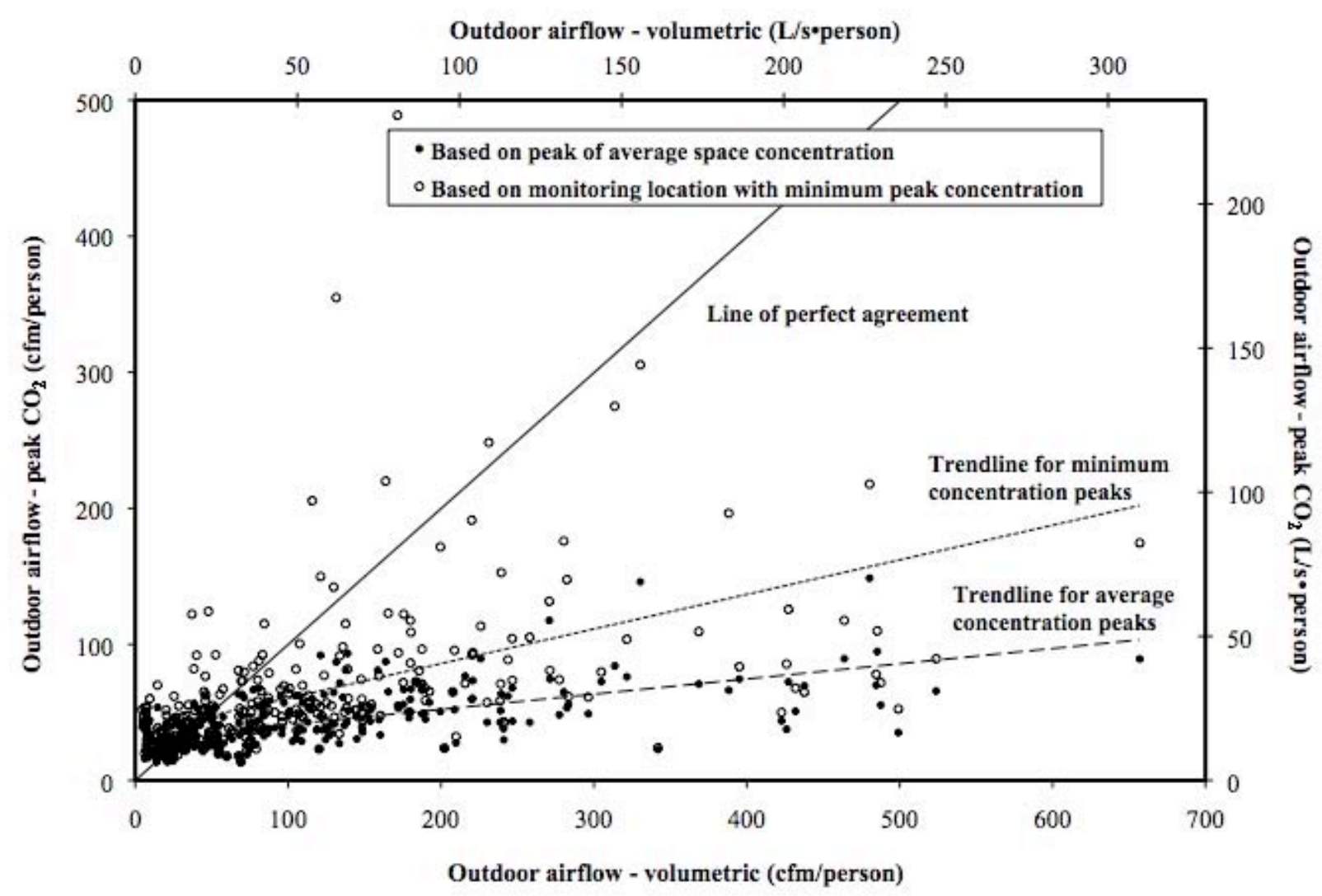

Figure $11 \mathrm{CO}_{2}$ peak vs. volumetric ventilation rate, using monitoring location with minimum peak concentration

While using the return concentrations and the minimum peak $\mathrm{CO}_{2}$ concentrations instead of the study space concentrations is not sufficient to explain the difference between the peak $\mathrm{CO}_{2}$ and the volumetric values, these two explanations are consistent with the existence of nonuniform concentrations in the study spaces.

If $\mathrm{CO}_{2}$ concentration variations between the study space and the rest of the building is an issue, then study spaces that are a whole building or are served by dedicated air handlers might be expected to exhibit better agreement between the peak indoor $\mathrm{CO}_{2}$-based and volumetric airflow values. The level of agreement between the two airflow rates was examined for test spaces corresponding to a whole building (only 6 cases) or which were served by dedicated air handlers (43 cases), but no obvious difference in the agreement was evident. Note that within-space nonuniformity may have been an issue in these spaces as well.

Association of peak-volumetric difference with various factors

In investigating the differences between the peak indoor $\mathrm{CO}_{2}$-based estimates and volumetric measurements of the outdoor airflows in the BASE buildings, a number of parameters were considered to see if they were associated with the magnitudes of the differences and therefore might offer some explanation.

Given the hypothesis that nonuniform indoor $\mathrm{CO}_{2}$ concentrations might be important, the standard deviation of the peak concentrations for the various indoor locations was computed for 
each study space. This standard deviation was then divided by the mean peak to determine the coefficient of variation (COV). Figure 12 is a plot of the relative difference between the volumetric and peak indoor $\mathrm{CO}_{2}$-based airflows (volumetric minus peak indoor $\mathrm{CO}_{2}$-based, divided by peak value) against the COV. The data in this figure do not show a strong dependence of the flow discrepancy on the COV.

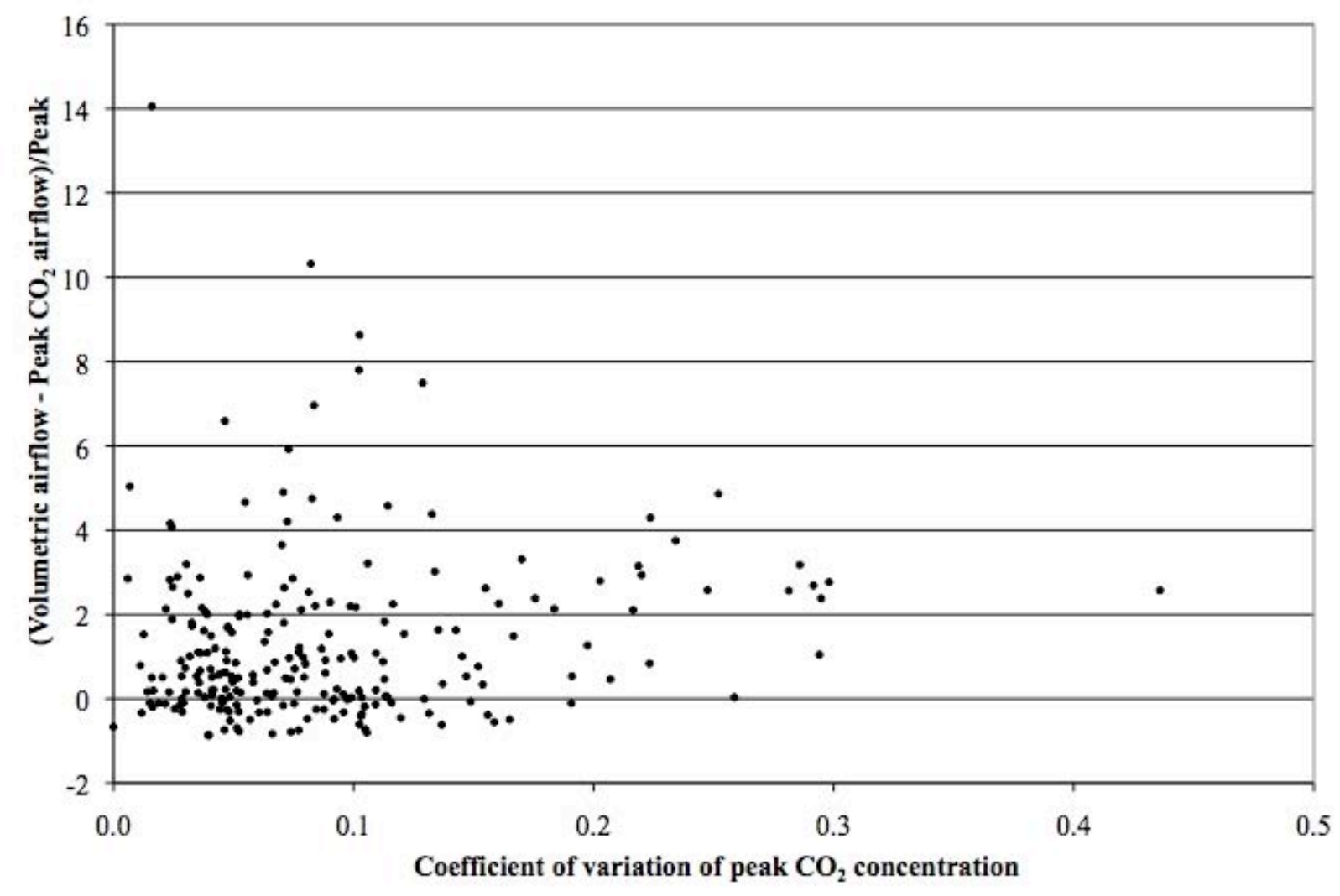

Figure 12 Relative difference between airflows vs. coefficient of variation

Given that the indoor concentrations are expected to be more uniform with more mixing, i.e., lower outdoor air fractions $(\% \mathrm{OA})$, the differences between the peak indoor $\mathrm{CO}_{2}$-based and volumetric airflows were also examined relative to \%OA for the study space. The results are plotted in Figure 13. The volumetric airflows are below the peak indoor $\mathrm{CO}_{2}$-based values at the lowest values of \%OA and become increasingly larger than the peak values as the \%OA increases. Note that the low \%OA values are consistent with more air mixing in the building, while higher values correspond to less. The trend seen here does support poor mixing as a potential explanation of the observed discrepancy. 


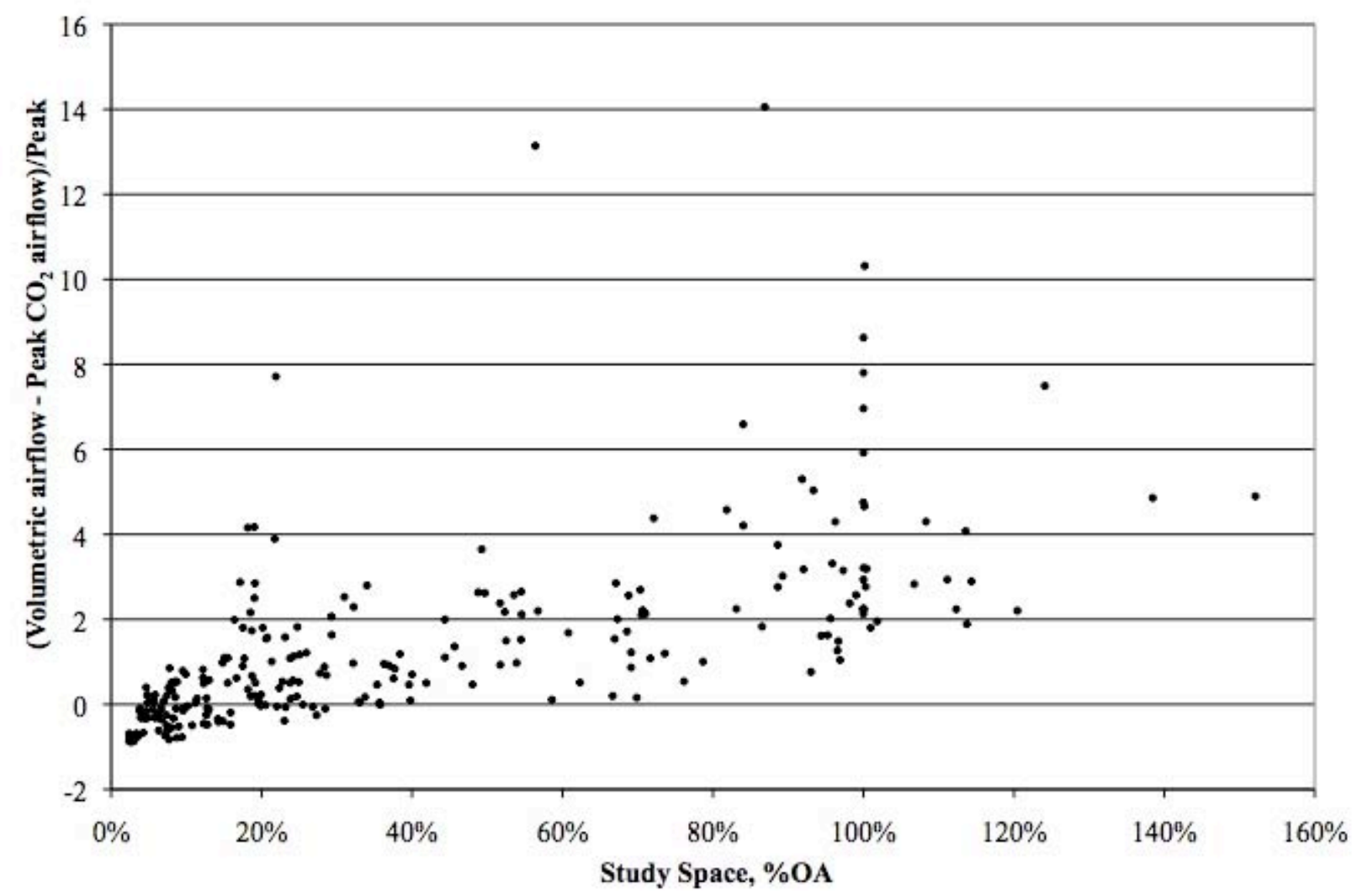

Figure 13 Relative difference between airflows vs. study space outdoor air fraction

However, low \%OA values also correspond to low outdoor airflow rates, and as seen in Figures 5 through 7, the discrepancy is largest as the volumetric outdoor airflow rate increases. Therefore the trend in Figure 13 may be simply a manifestation of the dependency already noted.

The discrepancy between the volumetric and peak indoor $\mathrm{CO}_{2}$-based airflow values were also examined for any dependence on a number of other factors, including the measured occupant density in the study space (number of people per unit floor area) and the estimated uncertainty of the peak indoor $\mathrm{CO}_{2}$-based airflow rate, but no dependence was observed.

Accuracy of volumetric airflows

While questions have been raised above regarding the precision and bias of the peak indoor $\mathrm{CO}_{2}$-based airflow rates, it is also reasonable to consider the accuracy of the traverse measurements. Industry guidance generally cites a measurement uncertainty of about $10 \%$ for duct traverses under good field conditions [5-7], but the basis for this estimate is not well defined. The key question in the current study is whether there is a reason to suspect that the traverse measurements are biased high, particularly for the higher values of outdoor airflow per person. These higher values are associated with higher duct velocities. In general, traverse errors are more of a concern for low velocities, and therefore there is no particular reason to suspect the higher airflow rates to be inaccurate. While duct leakage would cause the delivered outdoor airflow to the space to be lower than that measured at the air handler, the amount of leakage required to account for the observed differences would have to be extremely high, as much as $90 \%$ of the supply air leaking out of the ductwork. This is much larger than the commercial 
building duct leakage values that have been measured in the field to date, which are more in the $10 \%$ to $20 \%$ range [8].

One indication of the reliability of the duct traverse measurements is the comparison of the outdoor air fraction determined from the measured supply and outdoor airflow rates with the outdoor air fraction estimated from the $\mathrm{CO}_{2}$ concentrations in the return, outdoor, and supply airstreams. As discussed in the original report, these two independent measurements of the outdoor air fraction are on average consistent. These data are replotted in Figure 14, and while there is some scatter in the data, no strong bias is evident.

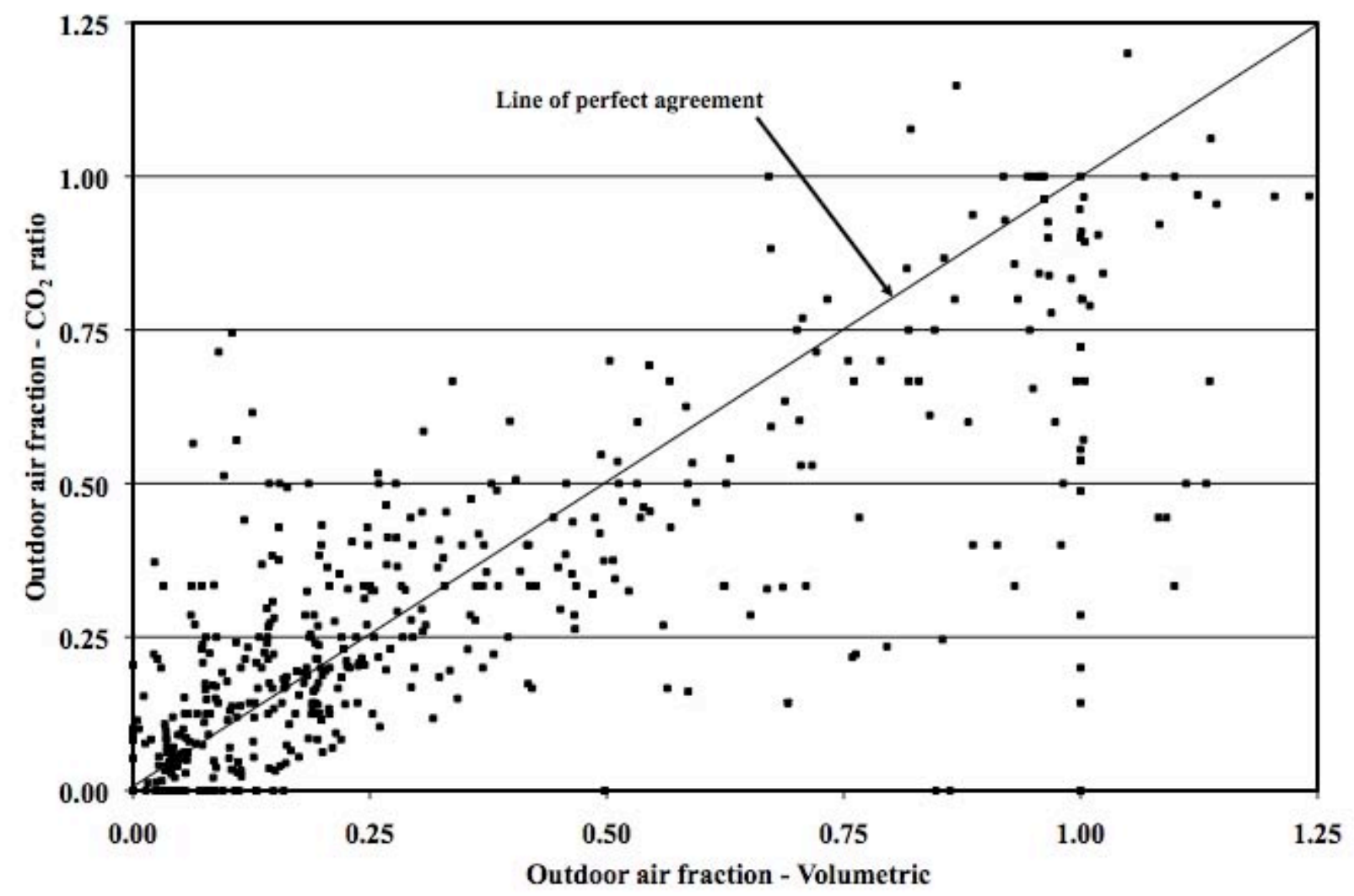

Figure 14 Outdoor air fraction based on $\mathrm{CO}_{2}$ ratio vs. based on volumetric flows

A similar comparison can be made by comparing the outdoor airflow intake of the air handlers calculated from the supply traverse value times the outdoor air fraction determined from the airstream $\mathrm{CO}_{2}$ concentrations with the outdoor airflow measured by the traverse measurements. These data are plotted in Figure 15, and while there is significant scatter in the plot the two methods of determining this quantity are on average consistent. The mean value of the former $\left(\mathrm{Q}_{\text {supply }} \mathrm{x} \% \mathrm{OA}\right)$ is about $4800 \mathrm{~L} / \mathrm{s}(10200 \mathrm{cfm})$, while the mean of the latter is about $5600 \mathrm{~L} / \mathrm{s}$ $(11900 \mathrm{cfm})$. Therefore, the traverse measurements of outdoor airflow are somewhat higher on average, but not enough to account for the differences noted related to the peak indoor $\mathrm{CO}_{2}$ based airflows. 


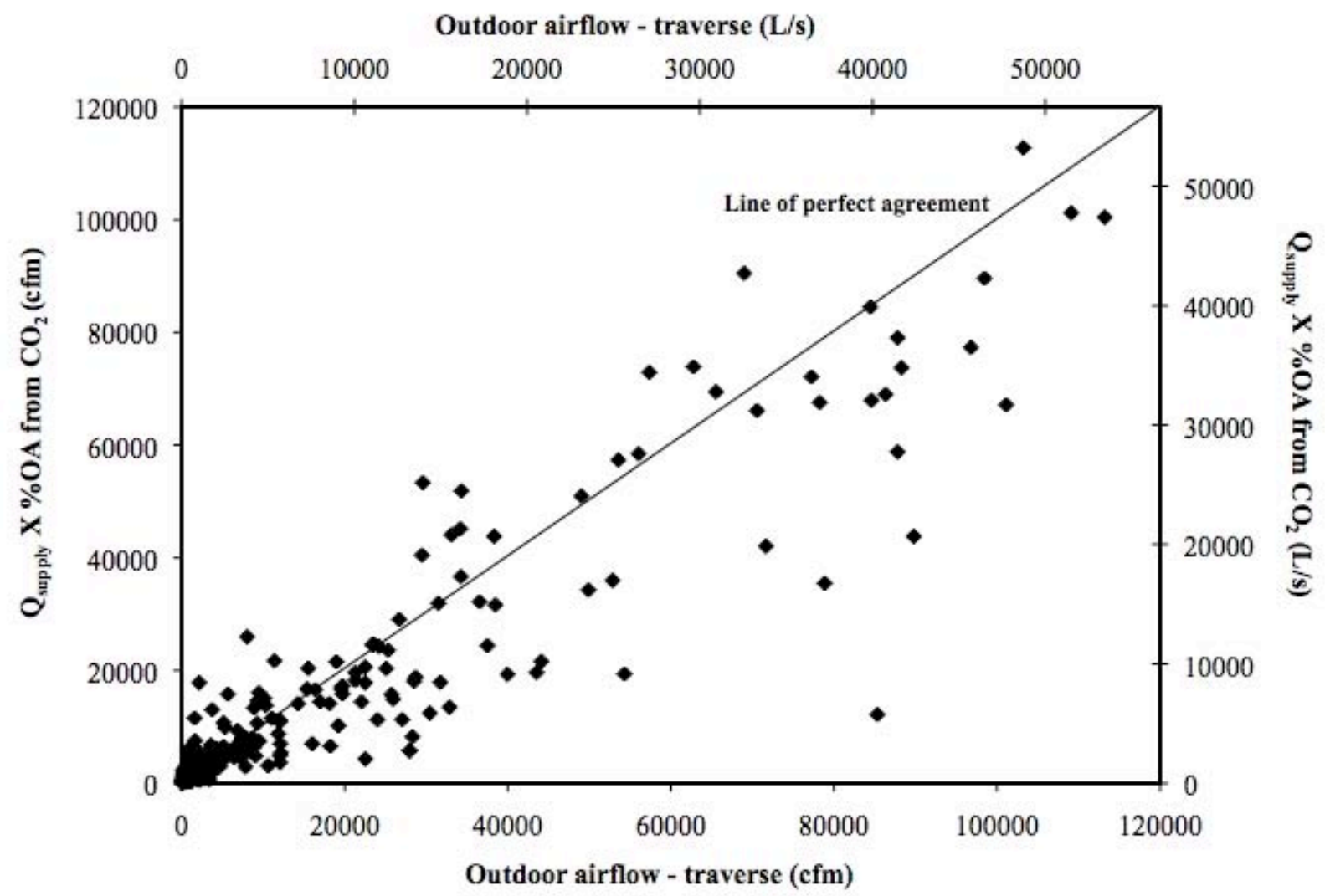

Figure 15 Outdoor airflow from $\mathrm{CO}_{2}$ ratio times supply airflow vs. volumetric outdoor airflow

Another check on the internal consistency of traverses was performed by calculating the ratio of the measured supply airflow to the sum of the outdoor and recirculation airflows. Only twelve events exist in which all three airflows were measured by duct traverses. Four of them are in one building where the supply and recirculation airflows are very close to each other, i.e., the outdoor air intake rate is quite low. The mean value of this ratio for all twelve events is 1.3; without the first building the mean is 1.1. This comparison does not prove that the traverse measurements are accurate but it does demonstrate their internal consistency. However, if a large and consistent systematic error existed, it might have been evident in these ratios.

Another confirmation of the validity of the traverses is the comparison of the supply airflow traverse measurements with the design values. While there is much variation expected in this comparison, the mean measured supply airflow rate is $5.12 \mathrm{~L} / \mathrm{s} \bullet \mathrm{m}^{2}\left(1.01 \mathrm{cfm} / \mathrm{ft}^{2}\right)$, while the mean of the corresponding design value is $4.98 \mathrm{~L} / \mathrm{s}^{-} \mathrm{m}^{2}\left(0.98 \mathrm{cfm} / \mathrm{ft}^{2}\right)$. This comparison does not prove that the traverse values are accurate, but if there were a large systematic error, it should be evident in comparing the mean measured to the mean design value.

Limited range of peak $\mathrm{CO}_{2}$ ventilation rates

As noted earlier, the ventilation rates based on the indoor peak $\mathrm{CO}_{2}$ concentrations do not exhibit the range of rates seen for the volumetric rates. Considering the data in Figure 7, the peak $\mathrm{CO}_{2}$ ventilation rates never exceed about $35 \mathrm{~L} / \mathrm{s}(74 \mathrm{cfm})$ per person, which corresponds to an indooroutdoor concentration difference of about $270 \mathrm{mg} / \mathrm{m}^{3}(150 \mathrm{ppm}(\mathrm{v}))$. In other words, the peak indoor $\mathrm{CO}_{2}$ concentrations are seldom less than $270 \mathrm{mg} / \mathrm{m}^{3}(150 \mathrm{ppm}(\mathrm{v}))$ above the outdoors. 
This lower limit on the peak values is a very curious result, for which no explanation has been identified.

Conclusion on Peak $\mathrm{CO}_{2}$ versus Traverse Issue

The final comparison worth noting is a "reality-check" on the air change rates calculated from the traverse measurements and from the peak $\mathrm{CO}_{2}$ estimates. The mean test space outdoor air change rate based on traverse measurements is $1.83 \mathrm{~h}^{-1}$, or $1.87 \mathrm{~L} / \mathrm{s}^{\bullet} \mathrm{m}^{2}\left(0.37 \mathrm{cfm} / \mathrm{ft}^{2}\right)$. Dividing this value by the mean outdoor air fraction of 0.31 (based on $\mathrm{CO}_{2}$ concentrations in the supply, return, and outdoor airstreams) yields $5.9 \mathrm{~h}^{-1}$ or $6.03 \mathrm{~L} / \mathrm{s}^{\bullet} \mathrm{m}^{2}\left(1.19 \mathrm{cfm} / \mathrm{ft}^{2}\right)$, which is a very reasonable value for the supply airflow rate in an office building. The mean outdoor air change rate based on peak indoor $\mathrm{CO}_{2}$ levels equals $0.83 \mathrm{~h}^{-1}$, or $0.85 \mathrm{~L} / \mathrm{s}^{\bullet} \mathrm{m}^{2}\left(0.17 \mathrm{cfm} / \mathrm{ft}^{2}\right)$, which when divided by the average outdoor air fraction is $2.7 \mathrm{~h}^{-1}$ or $2.74 \mathrm{~L} / \mathrm{s}^{\bullet} \mathrm{m}^{2}\left(0.55 \mathrm{cfm} / \mathrm{ft}^{2}\right)$. These supply airflow rates based on the peak $\mathrm{CO}_{2}$ values are well below, about half of, typical supply airflow rates for an office building.

In conclusion, the discrepancy between the peak indoor $\mathrm{CO}_{2}$-based and traverse-based outdoor airflow rates has not been fully explained. However, there is good reason to suspect that the peak indoor $\mathrm{CO}_{2}$-based values may not provide reliable estimates of the BASE study space outdoor air ventilation rates. In particular, the measured test space $\mathrm{CO}_{2}$ concentrations may be elevated relative to the actual space concentrations based on the observed differences between the space concentrations and return concentrations, the concentration variation among the test space locations, and the fact that the study space concentration is seldom less than $270 \mathrm{mg} / \mathrm{m}^{3}$ $(150 \mathrm{ppm}(\mathrm{v}))$ above the outdoor concentration.

\section{CONCLUSIONS}

This reanalysis of the BASE ventilation data has uncovered a small number of corrections, none of which impact the conclusions of the study. However, the updated dataset is now more reliable and should be used instead of the original version released in 2004 [1]. The attempt to explain the difference between the outdoor air ventilation rates determined by the duct traverses and those based on the peak $\mathrm{CO}_{2}$ concentrations in the study spaces revealed some potential explanations related to concentration nonuniformities but they were not able to fully explain the magnitude of the differences. It is unlikely that these differences will be explained through additional analyses of the BASE data. However, future efforts to understand these differences are warranted through experimental efforts specifically designed to investigate the problem. Other potential explanations could also be studied in the future, such as those related to assumed values for the $\mathrm{CO}_{2}$ generation rates by the occupants.

\section{ACKNOWLEDGEMENTS}

This effort was supported by the U.S. Environmental Protection Agency under Interagency Agreement No. DW-13-93936601. The authors express their appreciation to Gregory Brunner and John Girman at EPA for their support and assistance in this work. 


\section{REFERENCES}

[1] Persily, A. and Gorfain, J. 2004. Analysis of Ventilation Data from the U.S. Environmental Protection Agency Building Assessment Survey and Evaluation (BASE) Study, NIST 7145, National Institute of Standards and Technology.

[2] EPA. 2006. Building Assessment Survey and Evaluation (BASE) Study Data on Indoor Air Quality in Public and Commercial Buildings, (402-C-06-002).

[3] ASTM. 2007. D6245, Standard Guide for Using Indoor Carbon Dioxide Concentrations to Evaluate Indoor Air Quality and Ventilation.

[4] EPA. 2003. A Standardized EPA Protocol for Characterizing Indoor Air Quality in Large Office Building.

[5] ASHRAE. 1988. Standard 111-1988, Practices for Measurement, Testing, Adjusting, and Balancing of Building Heating, Ventilation, Air-Conditioning, and Refrigeration Systems.

[6] NEBB. 1991. Procedural Standards for Testing Adjusting Balancing of Environmental Systems. Rockville, Maryland, National Environmental Balancing Bureau.

[7] AABC. 1989. National Standards for Testing and Balancing Heating, Ventilating, and Air Conditioning Systems. Washington, DC, Associated Air Balance Council.

[8] Fisk. W.J., Delp, W.W., Diamond, R.C., Dickerhoff, D.J., Levinson, R., Modera, M.P., Nematollahi, M., and Wang, D. 2000. Duct Systems in Large Commercial Buildings: Physical Characterization, Air Leakage, and Heat Conduction Gains. Lawrence Berkeley National Laboratory Report No. LBNL-42339. 